\title{
Remedial Investigation Work Plan for J-Field, Aberdeen Proving Ground, Maryland
}

\section{PECEIVED \\ MAY 191995 \\ OSTI}

Environmental Assessment Division Argonne National Laboratory

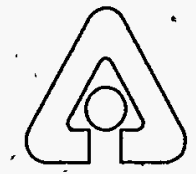

Operated by The University of Chicago, under Contract $W-31-109-$ Eng-38, for the United States Department of Energy 


\section{Argonne National Laboratory}

Argonne National Laboratory, with facilities in the states of Illinois and Idaho, is owned by the United States Govermment; and operated by the University of,Chicago under the provisions of a contract with the Department of Energy.

This-technical memo is a product of Argonne's Environmental Assessment. Division (EAD). For information on the-division's scientific and engineering activities, contact:

Director, Environmental Assessment Division

Argonnie National Laboratory

Argonne, Illinois 60439-4815

Telephone (708) 252-3107

Presented in this technical memo are preliminary results of ongoing work or work that is more limited in scope and depth than that described in formal . reports issued by the EAD.

\section{Publishing Support Services}

Publishing support services provided by Argonne's Information and Publishing Division.

r 1

\section{Disclaimer}

This report was prepared as an account of work sponsored by an agency of the United States Government. Neither the United States Government nor. any agency thereof, nor any of their employees, makes any warranty; express or implied, or assumes any legal liability or responsibility for the accuracy, completeness, or usefulness of any information, apparatus, product, or process disclosed, or represents that its use would nót infringe privately owned rights. Reference herein to any specific commercial product, process, or service by trade name, trademark, manufacturer, or otherwise, does not necessarily constifute or imply its endorsement, recommendation, or favoring by the United States Government or any agency thereof. The views and opinions of authors expressed herein do not necessarily state or reflect those of the United States Govemment or any ' agency thereof.

Reproduced directly from the best ávailable copy. i Available to DOE and DOE contractors from the Office of Scientific and Technical Information, P.O. Box 62, Oak Ridge, TN 37831; prices available from (615) 576-8401.

'Available to the public from the National Technical Information Service, U.S. Department of Commerce, 5285 Port Royál Road, Springfield, VA 22161. 


\section{DISCLAIMER}

Portions of this document may be illegible in electronic image products. Images are produced from the best available original document. 


\section{Remedial Investigation Work Plan for J-Field, Aberdeen Proving Ground, Maryland}

by P. Benioff, R. Biang, D. Dolak, C. Dunn, R. Haffenden, L. Martino, T. Patton, Y. Wang, and C. Yuen

Environmental Assessment Division,

Argonne National Laboratory, 9700 South Cass Avenue, Argonne, Illinois 60439

March 1995

Work sponsored by U.S. Army Aberdeen Proving Ground, Directorate of Safety, Health, and Environment

DISTRIBUTION OF THIS DOCUMENT IS UNLMMITED W.JJ 
हैy

This report is printed on recycled paper. 


\section{CONTENTS}

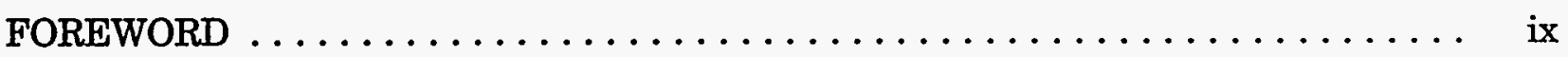

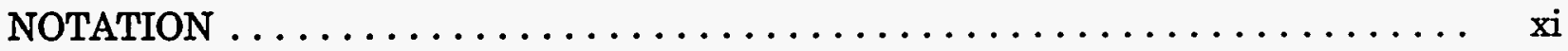

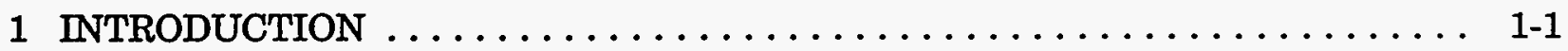

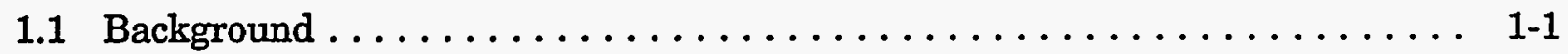

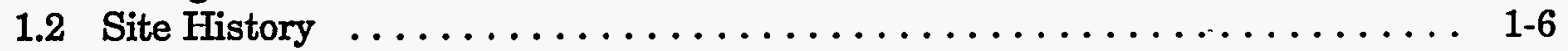

1.3 Objective and Scope of the Remedial Investigation Work Plan . . . . . . 1-8

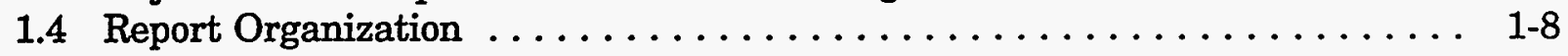

2 SITE SETTING AND BACKGROUND $\ldots \ldots \ldots \ldots \ldots \ldots \ldots \ldots \ldots \ldots \ldots \ldots \ldots$

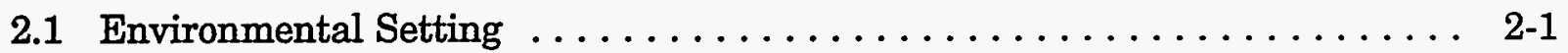

2.1.1 Surface Features $\ldots \ldots \ldots \ldots \ldots \ldots \ldots \ldots \ldots \ldots \ldots \ldots \ldots \ldots \ldots \ldots \ldots \ldots, 2-1$

2.1.2 Climate ...............................

2.1.3 Geology and Soils $\ldots \ldots \ldots \ldots \ldots \ldots \ldots \ldots \ldots \ldots \ldots \ldots \ldots \ldots \ldots \ldots \ldots, 2-1$

2.1.4 Surface Water $\ldots \ldots \ldots \ldots \ldots \ldots \ldots \ldots \ldots \ldots \ldots \ldots \ldots \ldots \ldots \ldots, 2-1$

2.1.5 Groundwater $\ldots \ldots \ldots \ldots \ldots \ldots \ldots \ldots \ldots \ldots \ldots \ldots \ldots \ldots \ldots, 2-4$

2.1.6 Ecology . . . . . . . . . . . . . . . . .

2.2 Background of J-Field Areas of Concern $\ldots \ldots \ldots \ldots \ldots \ldots \ldots \ldots \ldots$ 2-7

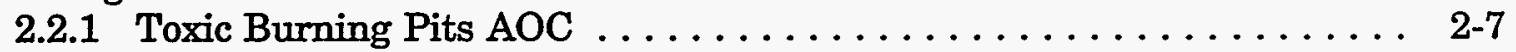

2.2.2 White Phosphorus Burning Pits AOC $\ldots \ldots \ldots \ldots \ldots \ldots \ldots \ldots$ 2-8

2.2.3 Riot Control Burning Pit AOC $\ldots \ldots \ldots \ldots \ldots \ldots \ldots \ldots \ldots \ldots \ldots \ldots \ldots \ldots \ldots \ldots$

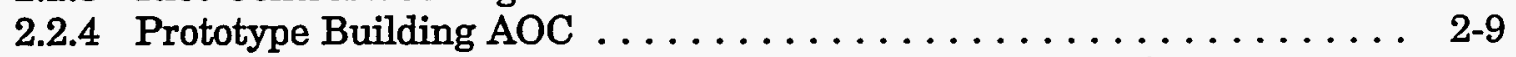

2.2.5 South Beach Demolition Ground AOC $\ldots \ldots \ldots \ldots \ldots \ldots \ldots \ldots .2-10$

2.2.6 South Beach Trench AOC . . . . . . . . . . . . . . . 2-10

2.2.7 Robins Point Demolition Ground AOC $\ldots \ldots \ldots \ldots \ldots \ldots \ldots \ldots 2-10$

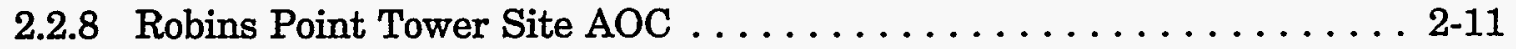

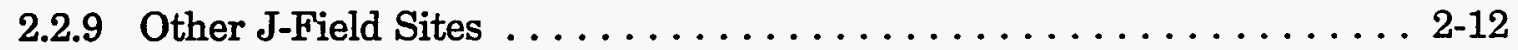

2.3 Preliminary Evaluation of J-Field Areas of Concern $\ldots \ldots \ldots \ldots \ldots \ldots$ 2-12

2.3.1 Toxic Burning Pits $\ldots \ldots \ldots \ldots \ldots \ldots \ldots \ldots \ldots \ldots \ldots \ldots \ldots \ldots \ldots \ldots \ldots \ldots, 12$

2.3.2 White Phosphorus Burning Pits $\ldots \ldots \ldots \ldots \ldots \ldots \ldots \ldots \ldots \ldots \ldots \ldots \ldots$

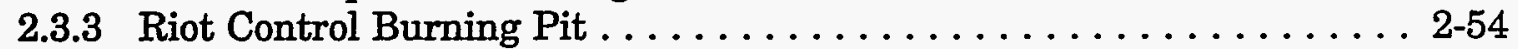

2.3.4 South Beach Trench . . . . . . . . . . . . . . . . . 2-62

2.3.5 South Beach Demolition Ground ..................... 2-64

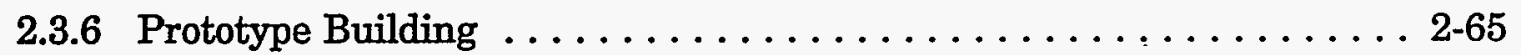

2.3.7 Robins Point Tower Site . . . . . . . . . . . . . 67

2.3.8 Robins Point Demolition Ground . . . . . . . . . . . . . . . 2-69

3 WORK PLAN RATIONALE $\ldots \ldots \ldots \ldots \ldots \ldots \ldots \ldots \ldots \ldots \ldots \ldots \ldots \ldots \ldots \ldots \ldots$

3.1 Data Needs ............................. 3-1

3.1.1 Unexploded Ordnance and Chemical Warfare Agents .......... 3-1

3.1.2 Sampling Approach $\ldots \ldots \ldots \ldots \ldots \ldots \ldots \ldots \ldots \ldots \ldots . \ldots \ldots$ 


\section{CONTENTS (Cont.)}

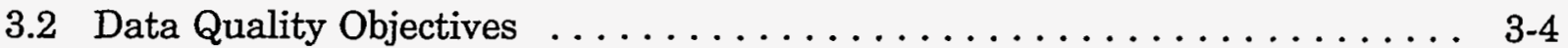

3.2.1 Site Characterization $\ldots \ldots \ldots \ldots \ldots \ldots \ldots \ldots \ldots \ldots \ldots \ldots \ldots \ldots \ldots, 4$

3.2.2 Risk Assessment Needs $\ldots \ldots \ldots \ldots \ldots \ldots \ldots \ldots \ldots \ldots \ldots$. $3-7$

3.2.3 Remedial Alternative Evaluation . . . . . . . . . . . . . . 3-13

3.3 Preliminary Identification of ARARs and

To-Be-Considered Information $\ldots \ldots \ldots \ldots \ldots \ldots \ldots \ldots \ldots \ldots \ldots \ldots \ldots \ldots \ldots$

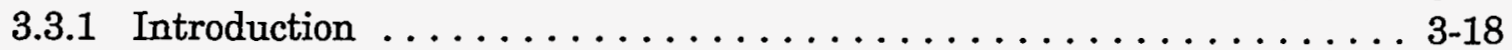

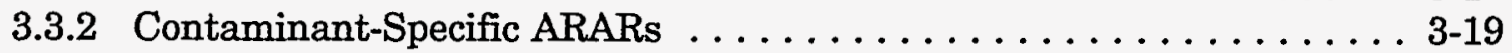

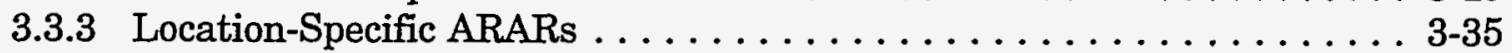

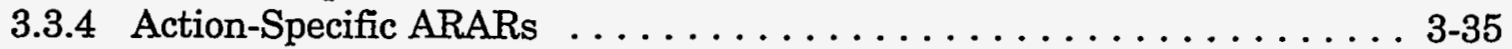

3.4 Preliminary Remediation Goals . . . . . . . . . . . . . . . . 3-35

3.4.1 Environmental Media of Concern and Potential Concern ....... 3-35

3.4.2 Contaminants of Potential Concern . . . . . . . . . . . . . 3-38

3.4.3 Present and Probable Future Land Use $\ldots \ldots \ldots \ldots \ldots \ldots \ldots . .42$

3.4.4 Potential Exposure Pathways . . . . . . . . . . . . . . . . 3-43

3.4.5 Preliminary Remediation Goals $\ldots \ldots \ldots \ldots \ldots \ldots \ldots \ldots . .43$

4 REMEDIAL INVESTIGATION TASKS $\ldots \ldots \ldots \ldots \ldots \ldots \ldots \ldots \ldots \ldots$

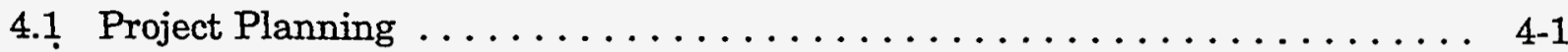

4.2 Plan Preparation and Interface with Ongoing Studies . . . . . . . . . 4-1

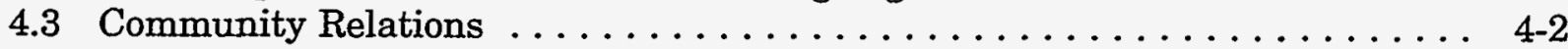

4.4 Field Investigation $\ldots \ldots \ldots \ldots \ldots \ldots \ldots \ldots \ldots \ldots \ldots \ldots \ldots \ldots \ldots \ldots \ldots, 2$

4.5 Sample Analysis and Validation $\ldots \ldots \ldots \ldots \ldots \ldots \ldots \ldots \ldots \ldots \ldots \ldots \ldots \ldots, 2$

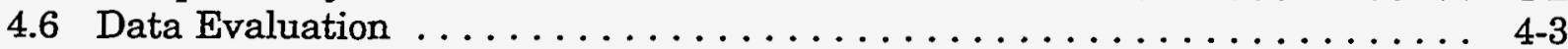

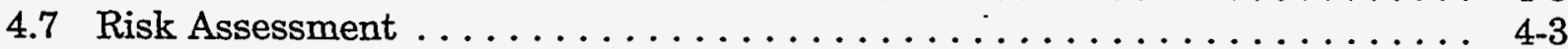

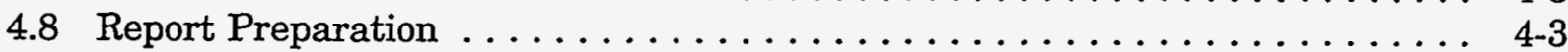

5 PROJECT MANAGEMENT $\ldots \ldots \ldots \ldots \ldots \ldots \ldots \ldots \ldots \ldots \ldots \ldots \ldots \ldots \ldots \ldots \ldots$

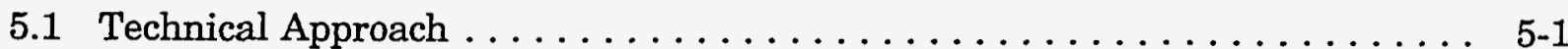

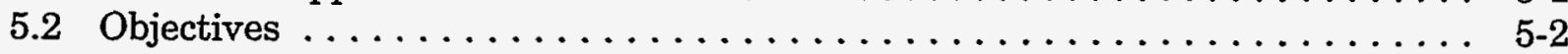

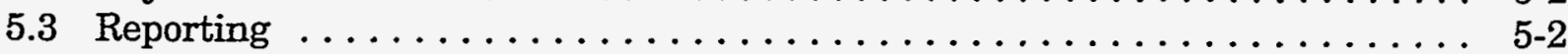

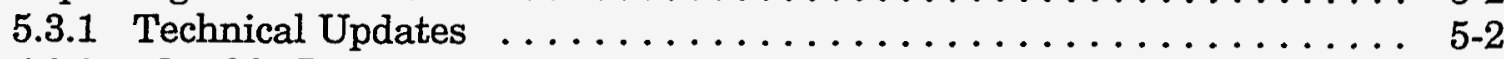

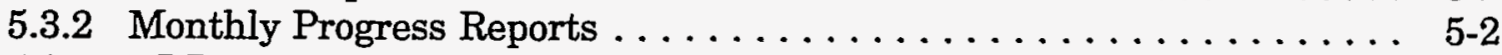

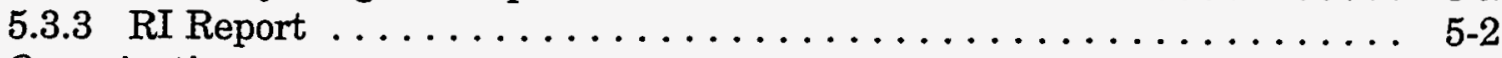

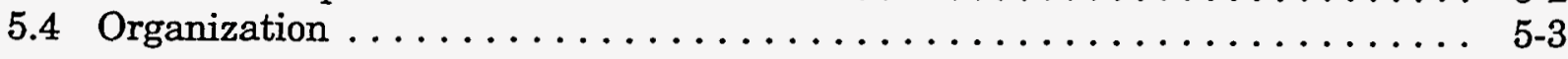

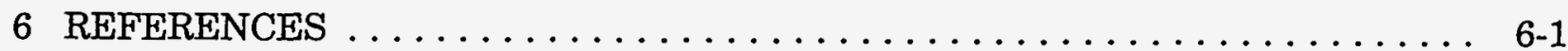

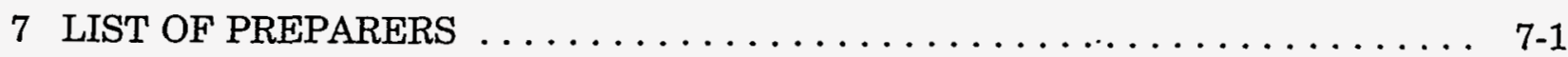

APPENDIX A: Summary of EPA Analytical Levels . . . . . . . . . . . A-1

APPENDIX B: Identification of Potential Areas of Concern at J-Field $\ldots \ldots \ldots$ B-1

APPENDIX C: Analytical Methods and Quantitation Limits ............ C-1 


\section{CONTENTS (Cont.)}

APPENDIX D: Project Schedules for the Aberdeen Proving Ground

Installation Restoration Program

D-1

\section{FIGURES}

1.1 Location of J-Field in the Edgewood Area at APG $\ldots \ldots \ldots \ldots \ldots \ldots \ldots$ 1-2

1.2 Location of J-Field and Major Associated Features

on the Gunpowder Neck Peninsula $\ldots \ldots \ldots \ldots \ldots \ldots \ldots \ldots \ldots \ldots$ 1-4

1.3 Locations of Areas of Concern and Principal

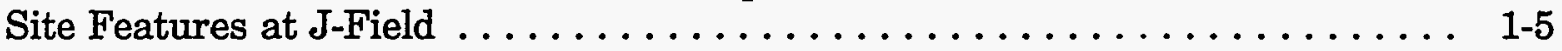

2.1 Topography of the J-Field Area $\ldots \ldots \ldots \ldots \ldots \ldots \ldots \ldots \ldots \ldots \ldots \ldots \ldots \ldots .2-2$

2.2 Locations of Woods, Marshes, Ponds, Open Fields,

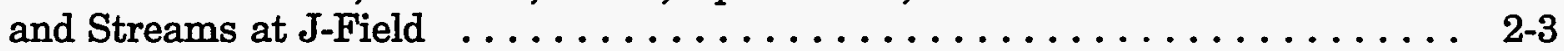

2.3 Groundwater Flow in the Surficial Aquifer, November $1989 \ldots \ldots \ldots \ldots \ldots$. $2-5$

2.4 Relative Contours for all Soil-Gas Parameters at the

Toxic Burning Pits Area ......................... 2-16

2.5 Relative Contours for Alkanes in Soil Gas from

the Toxic Burning Pits Area ....................... 2-17

2.6 Relative Contours for Combined TRCLE and TCLEE at the Toxic

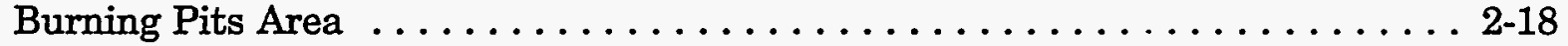

2.7 Relative Contours for Heavy Aromatics in Soil Gas from the Toxic

Burning Pits Area ............................ 2-19

2.8 Locations in the Toxic Burning Pits Area where Surface

Soil and Surface Water Samples Were Collected

during the 1986 RCRA Facility Assessment . . . . . . . . . . . . . 2-21

2.9 Locations where Soil Samples Were Collected by the USGS in $1991 \ldots \ldots$ 2-24

2.10 Locations of Soil Sampling Conducted by Weston in 1992 .

in the Toxic Burning Pits AOC . . . . . . . . . . . . . . . . . . . 2-26

2.11 Locations of Surface Water Samples Collected at J-Field in 1988 . . . . . . . . 2 2-31

2.12 Locations of Surface Water and Sediment Samples Collected at

$\mathrm{J}$-Field in 1992 . 


\section{FIGURES (Cont.)}

2.13 Locations of All Wells Installed at J-Field $\ldots \ldots \ldots \ldots \ldots \ldots \ldots \ldots .2-34$

2.14 Contours of TRCLE Concentrations in the Surficial Aquifer . . . . . . . . . 2-39

2.15 Relative Flux Contours for TCLEE at the White Phosphorus Pits . . . . . . 2-44

2.16 Locations of Soil Borings at the White Phosphorus Pits $\ldots \ldots \ldots \ldots \ldots$ 2-45

2.17 Locations of Surface Soil and Surface Water Samples in

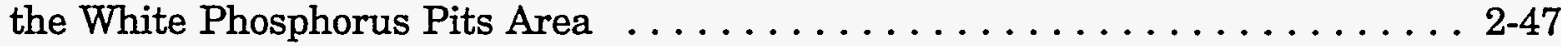

2.18 Relative Flux Contours of Heavy Aromatics

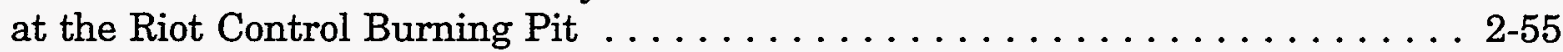

2.19 Locations of Soil Samples Collected by Weston in 1992 from

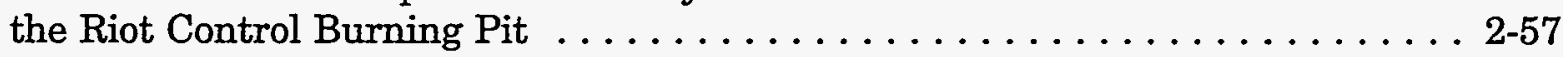

3.1 Data Quality Objectives for Human Health Risk Assessment . . . . . . . . . . . . 3-9

3.2 Phased Approach Proposed for J-Field Ecological Risk Assessment . . . . . . . 3-12

3.3 Relationship of Screening Criteria to the Nine Evaluation Criteria $\ldots \ldots \ldots$. $3-17$

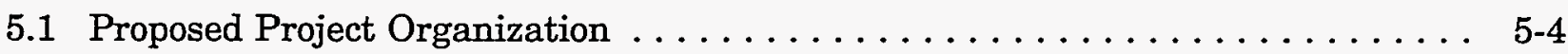

B.1 Locations of PAOCs at J-Field $\ldots \ldots \ldots \ldots \ldots \ldots \ldots \ldots \ldots \ldots \ldots \ldots \ldots \ldots$

\section{TABLES}

1.1 Summary of Disposal Activities at J-Field $\ldots \ldots \ldots \ldots \ldots \ldots \ldots \ldots \ldots \ldots$ 1-7

2.1 Summary of Previous Investigations at J-Field $\ldots \ldots \ldots \ldots \ldots \ldots \ldots \ldots \ldots$

2.2 Analytical Results for Analysis of Soil Samples from the Toxic Burning Pits AOC Main Burning Pits, January 1983 . . . . . . . . . . . . 2-20

2.3 Analytical Results for Analysis of Soil Samples J1-J20 from the Toxic

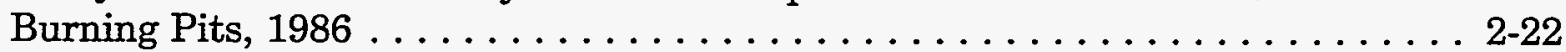

2.4 Analytical Results for Analysis of Soil Samples from the Toxic Burning Pits Area, April $1991 \ldots \ldots \ldots \ldots \ldots \ldots \ldots . .2-25$

2.5 Analytical Results for Target Compound List Analytes in Selected Soil Samples from the Toxic Burning Pits, 1992 


\section{TABLES (Cont.)}

2.6 Analytical Results for Target Analyte List Analytes in Selected Soil Samples from the Toxic Burning Pits, 1992 .

2.7 Analytical Results for Surface Water Samples from the Toxic Burning Pits Area, 1986 . . . . . . . . . . . . . . . . 2-30

2.8 Analytical Results for Groundwater from the P-Series

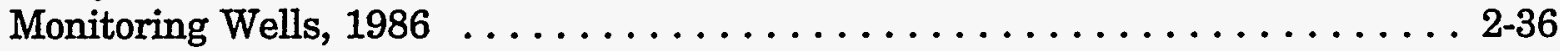

2.9 Analytical Results for Selected Inorganic Compounds, TOC, and Metals in Groundwater from the Toxic Burning Pits, 1990 . . . . . . . . . . . . 2-37

2.10 Analytical Results for Selected VOCs in Groundwater from

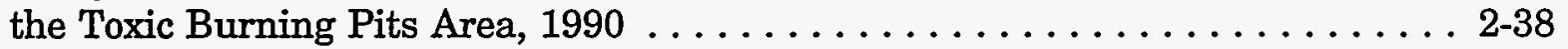

2.11 Analytical Results for Organosulfur and Explosives-Related Compounds in Groundwater from the Toxic Burning Pits Area, 1990 . . . . . . . . . . . . . 2-40

2.12 Analytical Results for Selected VOCs in Groundwater Samples from the Toxic Burning Pits Area, 1992 . . . . . . . . . . . . . . . . . . 2-41

2.13 Concentrations of Chemical Parameters in Soil from the White Phosphorus Pits at J-Field . . . . . . . . . . . . . . . 2-46

2.14 Analytical Results for Soil Samples J31 and J32 from the White Phosphorus Pits, 1986

2.15 Analytical Results for Soil Samples from the White Phosphorus Pits Area, April 1991 . . . . . . . . . . . . . . . . 2-49

2.16 Analytical Results for TCL and TAL Analytes in Selected Soil Samples from the White Phosphorus Pits, $1992 \ldots \ldots \ldots \ldots \ldots \ldots \ldots \ldots \ldots$. . . . . . . . .

2.17 Analytical Results for Surface Water Samples from the White Phosphorus Pits Area, 1986 .

2.18 Analytical Results for Soil Samples from the Riot Control Burning Pit Area, April 1991

2.19 Analytical Results for TCL Analytes in Selected Soil Samples from the Riot Control Burning Pit Area, $1992 \ldots \ldots \ldots \ldots \ldots \ldots$. . . . . . . . . . .

2.20 Analytical Results for TAL Analytes in Selected Soil Samples from the Riot Control Burning Pit Area, $1992 \ldots \ldots \ldots \ldots$. . . . . . . . 2-60

3.1 Threshold and Primary Balancing Factors to Consider in Detailed Evaluation of Selected J-Field Alternatives against Criteria . 


\section{TABLES (Cont.)}

3.2 State Regulations and To-Be-Considereds for J-Field $\ldots \ldots \ldots \ldots \ldots \ldots \ldots$. $3-20$

3.3 Federal Regulations and To-Be-Considereds for J-Field - Potential Contaminant-Specific Requirements . . . . . . . . . . . . . . . . .

3.4 Federal Regulations and To-Be-Considereds for J-Field - Potential

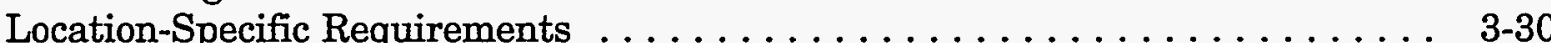

3.5 Federal Regulations and To-Be-Considereds for J-Field - Potential Action-Specific Requirements . .......................

3.6 Environmental Media of Concern or Potential Concern at the J-Field Sites .

3.7 Preliminary Identification of Contaminants of Potential Concern for the Toxic Burning Pits at J-Field . . . . . . . . . . . . . . . . . .

3.8 Preliminary Identification of Contaminants of Potential Concern at the White Phosphorus Burning Pits and Other J-Field Sites . . . . . . . . . 3-40

3.9 Federal Water Quality Criteria, Standards, and Guidelines for Contaminants of Potential Concern at J-Field .................

3.10 Atmospheric Criteria for Chemical Warfare Agents That Are Contaminants of Potential Concern at J-Field

A.1 Summary of EPA Analytical Levels Appropriate to Specific Data Uses . . . . . . . . . . . . . . . . . . . .

C.1 Target Compound List, Analytical Methods, and Quantitation Limits: Volatile Organic Compounds . . . . . . . . . . . . . . . . . . .

C.2 Target Compound List, Analytical Methods, and Quantitation Limits: Semivolatile Organic Compounds

C.3 Target Compound List, Analytical Methods, and Quantitation

Limits: Pesticides/PCBs/Aroclors . . . . . . . . . . . . . . . . . .

C.4 Target Analyte List, Analytical Methods, and Detection

Limits: Inorganic Chemicals

C.5 Quantitation Limits and Analytical Methods for Principal Degradation Products of Selected Chemical Warfare Agents

C.6 Quantitation Limits and Analytical Methods for Selected Explosives and Related Compounds 


\section{FOREWORD}

This document presents the Remedial Investigation Work Plan for the field work to be conducted as part of a remedial investigation/feasibility study (RI/FS) to be carried out at J-Field, Aberdeen Proving Ground, Maryland, pursuant to the Comprehensive Environmental Response, Compensation, and Liability Act (CERCLA), as amended. The RI/FS is to be conducted for the U.S. Army under the direction of the Directorate of Safety, Health, and Environment, Aberdeen Proving Ground. This report is one in a series of documents being prepared by Argonne National Laboratory to define the plans for RI/FS activities at J-Field. Other documents in this series include a Field Sampling Plan (Benioff et al. 1995); a Quality Assurance Project Plan (Prasad et al. 1995); and a Work Plan for the Focused Feasibility Study of the Toxic Burning Pits Area (Biang et al. 1995). Two other documents - an Ecological Risk Assessment Work Plan and a Work Plan for the Feasibility Study - are in preparation. 


\section{NOTATION}

The following is a list of abbreviations and acronyms, chemicals, and units of measure used in this document. Some acronyms used only in tables are defined in those tables.

\section{ABBREVIATIONS AND ACRONYMS}

\begin{tabular}{|c|c|}
\hline $\begin{array}{l}\text { AEC } \\
\text { ANL } \\
\text { AOC } \\
\text { APG } \\
\text { ARAR }\end{array}$ & $\begin{array}{l}\text { U.S. Army Environmental Center } \\
\text { Argonne National Laboratory } \\
\text { area of concern } \\
\text { Aberdeen Proving Ground } \\
\text { applicable or relevant and appropriate requirement }\end{array}$ \\
\hline $\begin{array}{l}\text { BDAT } \\
\text { BRA }\end{array}$ & $\begin{array}{l}\text { best demonstrated available technology } \\
\text { baseline risk assessment }\end{array}$ \\
\hline CERCLA & $\begin{array}{l}\text { Comprehensive Environmental Response, Compensation, and } \\
\text { Liability Act (as amended) }\end{array}$ \\
\hline CFR & Code of Federal Regulations \\
\hline CLP & Contract Laboratory Program \\
\hline $\mathrm{COE}$ & U.S. Army Corps of Engineers \\
\hline COMAR & Code of Maryland Regulations \\
\hline CRP & Community Relations Plan \\
\hline CTR & contract technical representative \\
\hline CWA & chemical warfare agent \\
\hline DANC & decontaminating agent, noncorrosive \\
\hline DSHE & Directorate of Safety, Health, and Environment (U.S. Army) \\
\hline ECC & environmental chemistry coordinator \\
\hline EMD & Environmental Management Division (Aberdeen Proving Ground) \\
\hline EP & extraction procedure \\
\hline EPA & U.S. Environmental Protection Agency \\
\hline ERA & ecological risk assessment \\
\hline ERT & emergency response team \\
\hline FFS & focused feasibility study \\
\hline FR & Federal Register \\
\hline FS & feasibility study \\
\hline FSP & Field Sampling Plan \\
\hline FWQC & federal water quality criterion \\
\hline $\mathrm{HE}$ & high explosives \\
\hline HEAST & Health Effects Assessment Summary Tables \\
\hline HSO & health and safety officer \\
\hline HSP & Health and Safety Plan \\
\hline
\end{tabular}




$\begin{array}{ll}\text { IRDMS } & \text { Installation Restoration Data Management System } \\ \text { IRIS } & \text { Integrated Risk Information System } \\ \text { IRP } & \text { Installation Restoration Program } \\ \text { MCL } & \text { maximum contaminant level } \\ \text { MCLG } & \text { maximum contaminant level goal } \\ \text { MDE } & \text { Maryland Department of the Environment } \\ \text { MSL } & \text { mean sea level } \\ \text { NCP } & \text { National Contingency Plan } \\ \text { ND } & \text { not detected } \\ \text { NPL } & \text { National Priorities List } \\ \text { OB } & \text { open burning } \\ \text { OD } & \text { open detonation } \\ \text { O\&M } & \text { operations and maintenance } \\ \text { OSHA } & \text { Occupational Safety and Health Administration } \\ \text { PAOC } & \text { potential area of concern } \\ \text { PARCC } & \text { precision, accuracy, representativeness, completeness, and c nparability } \\ \text { PB } & \text { Prototype Building } \\ \text { PRG } & \text { preliminary remediation goal } \\ \text { QA } & \text { quality assurance } \\ \text { QAO } & \text { quality assurance officer } \\ \text { QAPjP } & \text { Quality Assurance Project Plan } \\ \text { QC } & \text { quality control } \\ \text { RCP } & \text { Riot Control Burning Pit } \\ \text { RCRA } & \text { Resource Conservation and Recovery Act (as amended) } \\ \text { RFA } & \text { RCRA Facility Assessment } \\ \text { RfD } & \text { reference dose } \\ \text { RI } & \text { remedial investigation } \\ \text { RI/FS } & \text { remedial investigation/feasibility study } \\ \text { RME } & \text { reasonably maximally exposed } \\ \text { RPDG } & \text { Robins Point Demolition Ground } \\ \text { RPTS } & \text { Robins Point Tower Site } \\ \text { SAP } & \text { Sampling and Analysis Plan } \\ \text { SBDG } & \text { South Beach Demolition Ground } \\ \text { SBT } & \text { South Beach Trench } \\ \text { SMCL } & \text { secondary maximum contaminant level } \\ \text { SWMU } & \text { solid waste management unit } \\ \text { SWQS } & \text { state water quality standard } \\ \text { TAL } & \text { Target Analyte List } \\ \text { TBC } & \text { to be considered } \\ \text { TBP } & \text { Toxic Burning Pits } \\ \text { TCL } & \text { Target Compound List } \\ & \end{array}$


TDS

TSCA

USAEHA

USATHAMA

USGS

UXO

WPP total dissolved solids

Toxic Substances Control Act

U.S. Army Environmental Hygiene Agency

U.S. Army Toxic and Hazardous Materials Agency

U.S. Geological Survey

unexploded ordnance

White Phosphorus Burning Pits

\section{CHEMTCAL SYMBOLS AND ABBREVIATIONS}

BNA base neutral and acid extractable organic compounds

$\begin{array}{ll}\text { C2H3CL } & \text { vinyl chloride } \\ \text { C6H6 } & \text { benzene } \\ \text { CHCL3 } & \text { chloroform } \\ \text { CK } & \text { cyanogen chloride } \\ \text { CN } & \text { chloroacetophenone } \\ \text { CS } & \text { o-chlorobenzylidene malononitrile }\end{array}$

$\begin{array}{ll}\text { DANC } & \begin{array}{l}\text { decontaminating agent, noncorrosive } \\ \text { dichloroethylene }\end{array} \\ \text { DCE } & \text { 11,1-dichloroethylene } \\ \text { 12DCE } & \text { 1,2-dichloroethylene } \\ \text { trans-12DCE } & \text { trans-1,2-dichloroethylene } \\ \text { DDD } & \text { dichlorodiphenyldichloroethane } \\ \text { DDE } & \text { dichlorodiphenyldichloroethylene } \\ \text { DDT } & \text { dichlorodiphenyltrichloroethane } \\ \text { DM } & \text { adamsite } \\ \text { DNT } & \text { dinitrotoluene } \\ & \\ \text { FM } & \text { titanium tetrachloride } \\ \text { FS } & \text { sulfur trioxide/chlorosulfonic acid }\end{array}$

GA

GB

GD

GF

O-ethyl-N,N-dimethylphosphoramidacyanidate (tabun), a nerve agent isopropyl methylphosphonofluoridate (sarin), a nerve agent pinacolyl methylphosphonofluoridate (soman), a nerve agent cyclohexyl methylphosphonofluoridate, a nerve agent

MIBK . methyl isobutyl ketone

PAH polyaromatic hydrocarbon

PCB

PETN

polychlorinated biphenyl

penta-erythritol tetranitrate

PWP

plasticized white phosphorus

RDX

hexahydro-1,3,5-trinitro-1,3,4-triazine 


$\begin{array}{ll}\text { TCE } & \text { trichloroethane } \\ \text { 111TCE } & \text { 1,1,1-trichloroethane } \\ \text { 112TCE } & \text { 1,1,2-trichloroethane } \\ \text { TCLEA } & \text { 1,1,2,2-tetrachloroethane } \\ \text { TCLEE } & \text { tetrachloroethylene } \\ \text { TKN } & \text { total Kjeldahl nitrogen } \\ \text { TOC } & \text { total organic carbon } \\ \text { TOX } & \text { total organic halogen } \\ \text { TRCLE } & \text { trichloroethylene } \\ \text { VOC } & \text { volatile organic compound } \\ \text { VX } & \text { o-ethyl S-(2-diisopropylaminoethyl methylphosphonothioate) = } \\ & \text { methylphosphonothioic acid, a nerve agent } \\ \text { WP } & \text { white phosphorus }\end{array}$

\section{UNITS OF MEASURE}

$\begin{array}{ll}{ }^{\circ} \mathrm{C} & \text { degree(s) Celsius } \\ \mathrm{Ci} & \text { curie(s) } \\ \mathrm{pCi} & \text { picocurie(s) } \\ \mathrm{d} & \text { day(s) } \\ \mathrm{dB}(\mathrm{A}) & \text { decibel(s) (A-weighted) } \\ { }^{\circ} \mathrm{F} & \text { degree(s) Fahrenheit } \\ \mathrm{ft} & \text { foot (feet) } \\ \mathrm{ft}^{2} & \text { square foot (feet) } \\ \mathrm{g} & \text { gram(s) } \\ \mathrm{\mu g} & \text { microgram(s) } \\ \mathrm{mg} & \text { milligram(s) } \\ \mathrm{kg} & \text { kilogram(s) } \\ \mathrm{h} & \text { hour(s) } \\ \mathrm{in} . & \text { inch(es) } \\ \mathrm{L} & \text { liter(s) } \\ \mathrm{lb} & \text { pound(s) } \\ \mathrm{m} & \text { meter(s) } \\ \mathrm{mi} & \text { mile(s) } \\ \mathrm{ppb} & \text { part(s) per billion } \\ \mathrm{ppm} & \text { part(s) per million }\end{array}$




\section{INTRODUCTION}

\subsection{BACKGROUND}

The Environmental Management Division (EMD) of Aberdeen Proving Ground (APG), Maryland, is conducting a remedial investigation and feasibility study (RI/FS) of the J-Field area at APG pursuant to the Comprehensive Environmental Response, Compensation, and Liability Act, as amended (CERCLA). J-Field is within the Edgewood Area of APG in Harford County, Maryland (Figure 1.1). Since World War II, activities in the Edgewood Area have included the development, manufacture, testing, and destruction of chemical agents and munitions. These materials were destroyed at J-Field by open burning ${ }^{1}$ and open detonation (OB/OD).

Considerable archival information about J-Field exists as a result of efforts by APG staff to characterize the hazards associated with the site. Contamination of J-Field was first detected during an environmental survey of the Edgewood Area conducted in 1977 and 1978 by the U.S. Army Toxic and Hazardous Materials Agency (USATHAMA) (predecessor to the U.S. Army Environmental Center [AEC]). As part of a subsequent USATHAMA environmental survey, 11 wells were installed and sampled at J-Field. Contamination at $\mathrm{J}$-Field was also detected during a munitions disposal survey conducted by Princeton Aqua Science in 1983. The Princeton Aqua Science investigation involved the installation and sampling of nine wells and the collection and analysis of surficial and deep composite soil samples. In 1986, a Resource Conservation and Recovery Act (RCRA) permit (MD3-21-0021355) requiring a basewide RCRA Facility Assessment (RFA) and a hydrogeologic assessment of J-Field was issued by the U.S. Environmental Protection Agency (EPA). In 1987, the U.S. Geological Survey (USGS) began a two-phased hydrogeologic assessment in which data were collected to model groundwater flow at J-Field. Soil-gas investigations were conducted, several well clusters were installed, a groundwater flow model was developed, and groundwater and surface water monitoring programs were established that continue today.

While APG was pursuing the investigation of J-Field under RCRA corrective action, the Edgewood Area was added to the National Priorities List (NPL) on February 21, 1990. Because of that listing, an RI/FS is required for the entire Edgewood Area pursuant to Modification 2 of the RCRA Permit and a March 1990 Federal Facility Agreement between EPA Region III and the Department of the Army. The corrective action requirements of RCRA have been preempted, and J-Field is being evaluated under CERCLA.

1 Pursuant to Title 40, Code of Federal Regulations (40 CFR), Part 260.10, "open burning" means the combustion of any material without the following characteristics:

(1) Control of combustion air to maintain adequate temperature for efficient combustion,

(2) Containment of the combustion-reaction in an enclosed device to provide sufficient residence time and mixing for complete combustion, and

(3) Control of emission of the gaseous combustion products. 


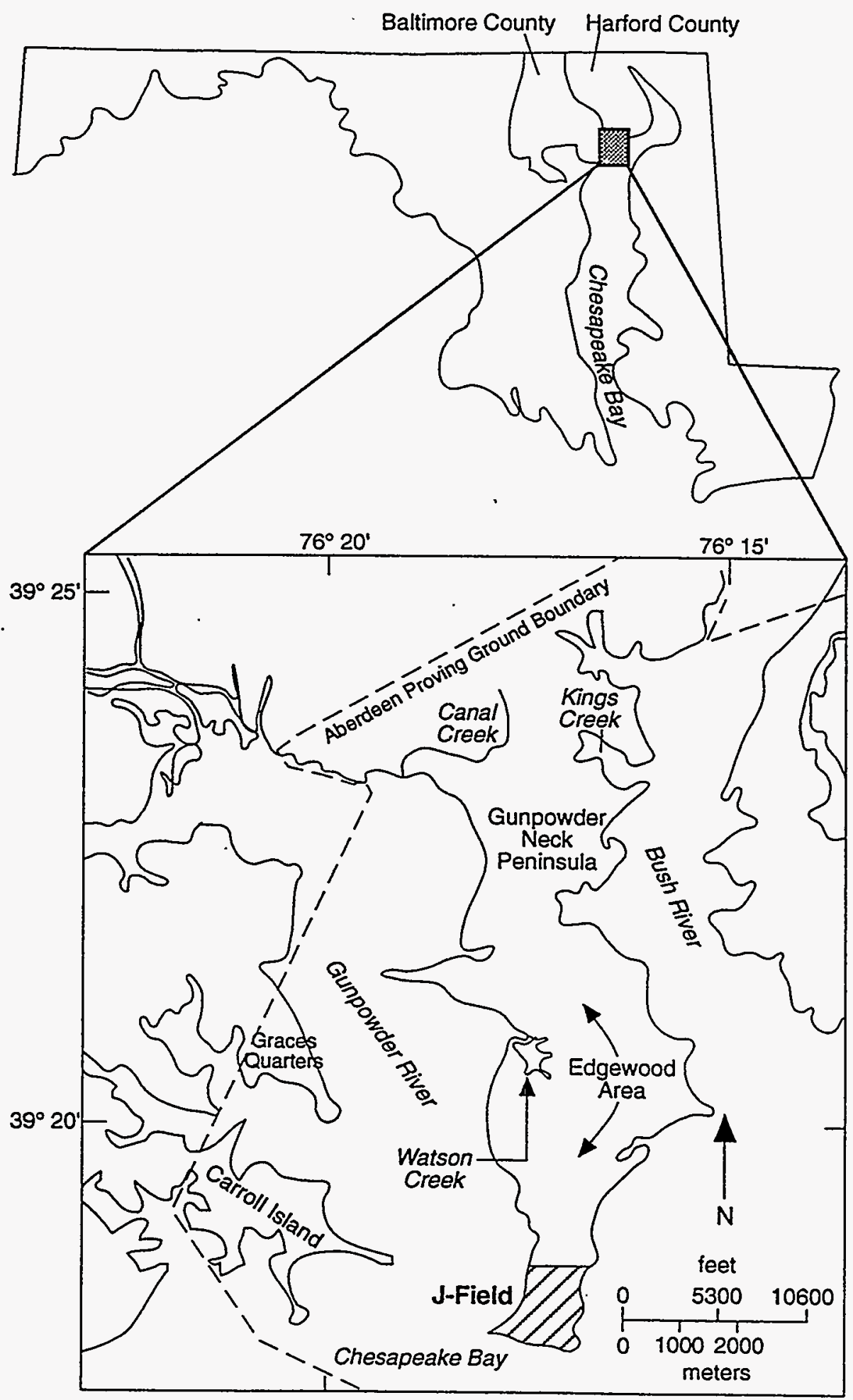

FIGURE 1.1 Location of J-Field in the Edgewood Area at APG (Source: Adapted from Hughes 1993) 
J-Field is almost flat and is covered by open fields, woods, and nontidal marshes. It encompasses about 460 acres at the southern end of the Gunpowder Neck Peninsula (Figure 1.2). The peninsula is surrounded by tidal estuaries on three sides - Gunpowder River to the west, Chesapeake Bay to the south, and Bush River to the east. For the purposes of the RI/FS, J-Field has been divided into eight geographic areas or features that are designated in this report as areas of concern (AOCs): the Toxic Burning Pits (TBP), the White Phosphorus Burning Pits (WPP), the Riot Control Burning Pit (RCP), the Robins Point Demolition Ground (RPDG), the Robins Point Tower Site (RPTS), the South Beach Demolition Ground (SBDG), the South Beach Trench (SBT), and the Prototype Building (PB) (Figure 1.3). These AOCs correspond to the eight solid waste management units (SWMUs) identified in the RCRA Facility Assessment, Edgewood Area, Aberdeen Proving Ground, MD (Nemeth 1989). Several subareas within these AOCs could represent discrete sources of contamination. The AOCs and their associated subareas are as follows:

- Toxic Burning Pits (TBP) AOC

- Main Burning Pits (consisting of a northern burning pit and a southern burning pit)

- Methylphosphonothioic Acid (VX) Burning Pit

- Mustard Burning Pit

- Pushout Area

- Liquid Smoke Disposal Pit

- Demolition Area

- Storage/Unloading Area

- Square Pit

- White Phosphorus Burning Pits (WPP) AOC

- Principal Burning Pits (consisting of a northern burning pit, a southern burning pit, and an associated bermed depression that received runoff from the northern burning pit)

- Pushout Area

- Mounded Areas

- Historic White Phosphorus Disposal Area (located south to southeast of the existing principal burning pits)

- Riot Control Burning Pit (RCP) AOC

- Burning Pit

- Pushout Area

- Robins Point Demolition Ground (RPDG) AOC

- Active Area

- Inactive Area

- Robins Point Tower Site (RPTS) AOC 


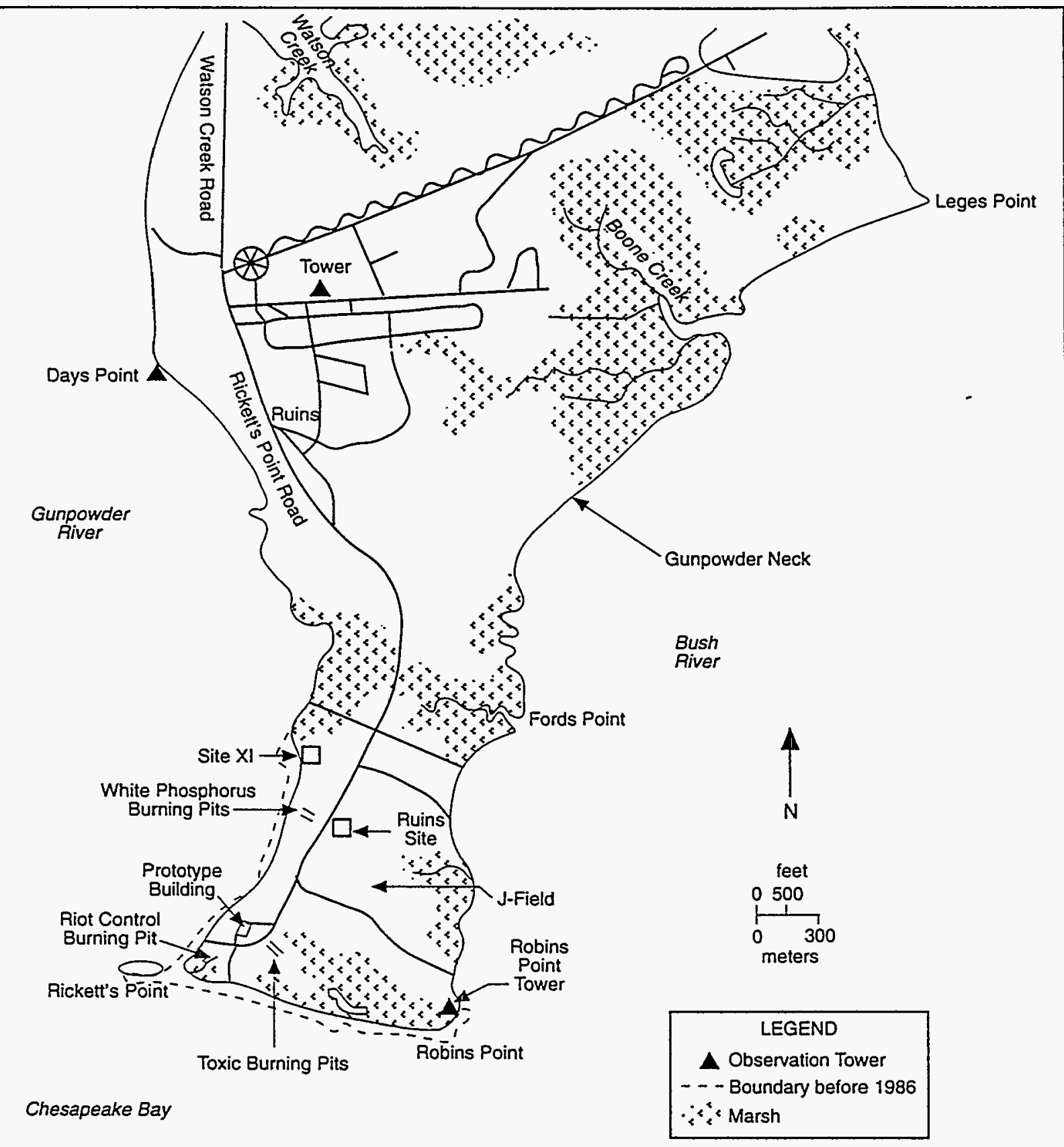

FIGURE 1.2 Location of J-Field and Major Associated Features on the Gunpowder Neck Peninsula (Source: Adapted from Hughes 1993) 


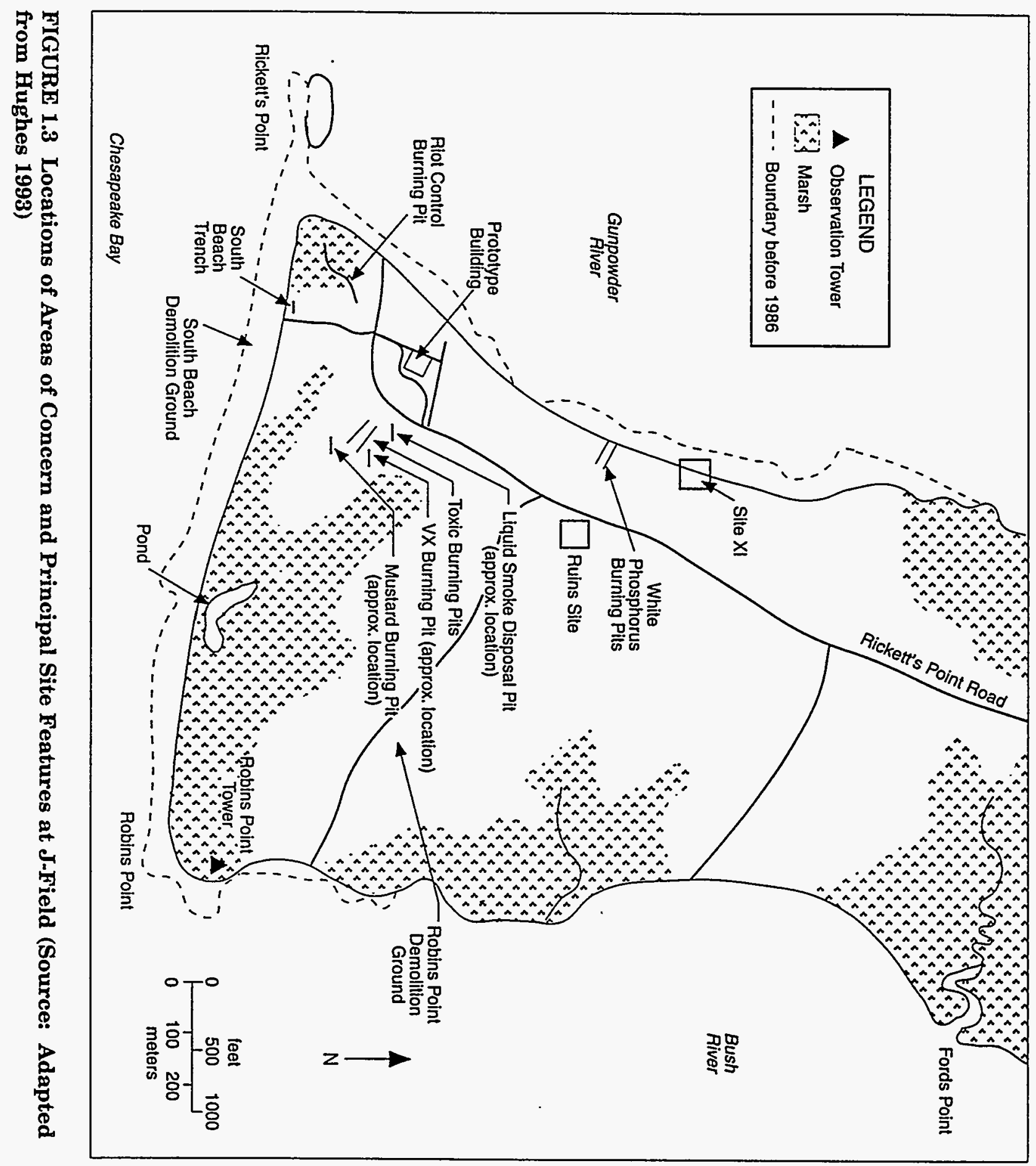


- South Beach Trench (SBT) AOC

- South Beach Demolition Ground (SBDG) AOC

- Prototype Building (PB) AOC

Although most of the AOCs are no longer used for OB/OD, a portion of the RPDG is currently active and is operating with interim status under RCRA. A RCRA Part B permit application was submitted in November 1988. An amended permit application is being prepared to update the November 1988 submittal. An open burning pan located $50 \mathrm{~m}$ west of the PB and an open detonation area at the WPP AOC are also being used for emergency disposal operations.

\subsection{SITE HISTORY}

The extent of activities at J-Field before World War II is unknown; however, a terrain map from the 1920s-1930s era indicates that some areas of J-Field were cleared at that time. These cleared areas may have been used for test activities (Nemeth 1989; U.S. Army Corps of Engineers [COE] 1923). During World War II, J-Field was used to test high explosives (HE) and chemical munitions. In addition, chemical agents, chemical wastes, and HE were burned or detonated in open pits or buried under several feet of soil. The depths of the pits were maintained by pushing burned soil and ash out toward the nearby marshes. In the case of the TBP AOC, this procedure moved the edge of the adjacent marsh eastward more than $100 \mathrm{ft}$ (Sonntag 1991). Also during World War II, steel-reinforced structures (such as bunkers, buildings, and slab walls) were built at J-Field to use as targets for conventional munitions.

Available information indicates that chemicals disposed of at J-Field have included nerve agents (such as VX), blister agents, riot control agents, white phosphorus, chlorinated solvents, and drummed chemical wastes generated by research laboratories, process laboratories, pilot plants, and machine and maintenance shops. Between 1946 and 1971, limited testing of lethal chemical agents continued at J-Field (Nemeth 1989). Open-air testing of lethal chemical agents stopped in 1969 (Nemeth 1989). Disposal activities at various J-Field locations are summarized in Table 1.1.

Procedures for open burning in J-Field pits involved placing 3-4 ft of wood dunnage in a pit, placing the materials to be burned on top of the dunnage, adding fuel oil, and igniting it. Scrap metal items were removed and reburned in the same manner in a reburn pit. Large metal items were recovered and disposed of as scrap.

Decontamination procedures included the use of a chlorinating agent known as "decontaminating agent, noncorrosive" (DANC). DANC is an organic $N$-chloroamide compound in solution with 1,1,2,2-tetrachloroethane (TCLEA) that was used to decontaminate 
TABLE 1.1 Summary of Disposal Activities at J-Field

\begin{tabular}{|c|c|c|}
\hline Site Name & Period of Use & Activity \\
\hline $\begin{array}{l}\text { Toxic Burning Pits } \\
\text { (originally } \\
5 \text { separate pits; } \\
\text { only } 2 \text { remain) }\end{array}$ & $1940-1980$ & $\begin{array}{l}\text { OB/OD of HE in southeastern portion. } \\
\text { Disposal of HE-filled munitions, nerve } \\
\text { agents, mustard, liquid smoke, } \\
\text { chlorinated solvents, and radioactive } \\
\text { chemicals. }\end{array}$ \\
\hline $\begin{array}{l}\text { White Phosphorus } \\
\text { Burning Pits }\end{array}$ & $\begin{array}{l}\text { Late } 1940 \mathrm{~s}-1980 \text {; } \\
\text { occasional emergency disposal } \\
\text { of white phosphorus }\end{array}$ & $\begin{array}{l}\text { OB/OD of white phosphorus, } \mathrm{PWP}, \\
\text { other chemicals. Potential for disposal } \\
\text { of } \mathrm{CN}^{\mathrm{b}} \text { and trichloroethylene. }\end{array}$ \\
\hline $\begin{array}{l}\text { Riot Control } \\
\text { Burning Pit Area }\end{array}$ & $\begin{array}{l}\text { Late } 1940 \text { s to early } 1970 \mathrm{~s} \\
\text { riot control agent disposal, } \\
1960 \text { s to early } 1970 \text { s }\end{array}$ & $\begin{array}{l}\mathrm{OB} \text { of chemicals, chemical-filled } \\
\text { munitions, riot control agents (CS, } \\
\text { CN). }\end{array}$ \\
\hline $\begin{array}{l}\text { Robins Point } \\
\text { Demolition Ground }\end{array}$ & Late 1970s-present & $\begin{array}{l}\text { OD of explosive materials, sensitive } \\
\text { and unstable chemicals. }\end{array}$ \\
\hline $\begin{array}{l}\text { South Beach } \\
\text { Demolition Ground }\end{array}$ & Late 1950s-1970s & $\mathrm{OD}$ of $\mathrm{HE}$. \\
\hline $\begin{array}{l}\text { Prototype Building } \\
\text { Area }\end{array}$ & During World War II & $\begin{array}{l}\text { Stored wastes and HE munitions. } \\
\text { Possible storage of solid wastes in } \\
\text { building or nearby. Building used to } \\
\text { test bombing effects. Periodically used } \\
\text { for storage since World War II. }\end{array}$ \\
\hline $\begin{array}{l}\text { Robins Point Tower } \\
\text { Site }\end{array}$ & Late $1950 \mathrm{~s}-1960 \mathrm{~s}$ & $\begin{array}{l}\text { Potential test burn of radioactively } \\
\text { contaminated wood. }\end{array}$ \\
\hline $\begin{array}{l}\text { South Beach } \\
\text { Trench }\end{array}$ & Late 1950s & Unknown. \\
\hline
\end{tabular}

a Plasticized white phosphorus.

b Chloroacetophenone.

c o-Chlorobenzylidene malononitrile.

Sources: Adapted from Nemeth (1989); EPA and U.S. Department of the Army (1990). 
mustard, lewisite, and VX. It typically contained 90-95\% (by weight) TCLEA. If recovered scrap materials were decontaminated with DANC in the pit before being removed, the oxidizing agent would degrade. The most significant impact from this procedure would have been the introduction of TCLEA into the environment. Available information indicates that the use of DANC at J-Field was widespread and common (Nemeth 1989).

Disposal of radioactive waste is known to have occurred at J-Field. The TBP area was used for disposal of small amounts of radioactively labeled chemicals. In addition, test burns of contaminated wood wastes, including wood contaminated with radium and strontium-90, may have been conducted at the RPTS (Nemeth 1989).

J-Field has had only limited use since 1980. However, the RPDG and the WPP AOCs are still occasionally used for the destruction of explosives-related materials (Nemeth 1989).

\subsection{OBJECTIVE AND SCOPE OF THE REMEDIAL INVESTIGATION WORK PLAN}

The purpose of an RI/FS is to characterize the nature and extent of the risks posed by contaminants present at a site and to develop and evaluate options for remedial actions. The overall objective of the RI is to provide a comprehensive evaluation of site conditions, types and quantities of contaminants present, release mechanisms and migration pathways, target populations, and risks to human health and the environment. The information developed during the RI provides the basis for the design and implementation of remedial actions during the FS.

The purpose of this RI Work Plan is to define the tasks that will direct the remedial investigation of the J-Field site at APG. Tasks are based on the procedures developed by the EPA in Guidance for Conducting Remedial Investigations and Feasibility Studies under CERCLA, Interim Final (EPA 1988).

\subsection{REPORT ORGANIZATION}

Section 1 presents the purpose and scope of the RI Work Plan. Section 2 summarizes the site background, environmental setting, and previous and ongoing investigations conducted at J-Field. Also included in Section 2 is an overview of available information about the nature and extent of contamination at each AOC, the types of waste present, and the potential pathways of contaminant migration. The environmental setting includes site topography, geology, soils, surface water, groundwater, climate, and ecology.

Section 3 presents the work plan rationale and discusses data requirements and data quality objectives (DQOs) for the various disciplines involved in completing the RI. Section 3 also discusses applicable or relevant and appropriate requirements (ARARs) (including promulgated rules and regulations to be considered) and the role of remediation objectives and goals. 
Tasks to be carried out in the RI for J-Field and the project schedule are described in Section 4. An overview of administrative responsibilities is presented in Section 5, and references cited in this report are listed in Section 6. A list of preparers of the RI Work Plan is presented in Section 7. Appendix A provides a summary of EPA analytical levels, and Appendix B discusses potential areas of concern (PAOCs) at J-Field. Tables of analytical methods and quantitation limits for various chemical compounds are provided in Appendix $C$, and a schedule for the Installation Restoration Program at APG is provided in Appendix D. 


\section{SITE SETTING AND BACKGROUND}

\subsection{ENVIRONMENTAL SETTING}

\subsubsection{Surface Features}

J-Field is nearly flat, with a maximum relief of about $10 \mathrm{ft}$. The ground surface slopes gently toward marshy areas or toward Chesapeake Bay and on-site surface water. In some places, wave erosion has formed short, steep cliffs (2-10 ft high) along the shore (Hughes 1993).

Surface water occurs in demolition craters, in marsh areas, and in a few open ponds within the marshes. Between December and May water collects in wooded areas where drainage is poor because the low-permeability soils slow the rate of infiltration. Figure 2.1 shows the overall topography of the site.

\subsubsection{Climate}

The climate in the area of APG is temperate and moderately humid and is moderated by the presence of Chesapeake Bay. The average annual precipitation of 45 in. is distributed relatively uniformly during the year. The average annual temperature is about $54^{\circ} \mathrm{F}$ (Nemeth 1989; Hughes 1993).

\subsubsection{Geology and Soils}

The stratigraphy of J-Field consists of Quaternary (Talbot) sediments underlain by Cretaceous (Potomac Group) sediments. The Quaternary sediments constitute a fluvial, estuarine, and marginal marine unit of sand, gravel, and silty clay. The Cretaceous sediments are a sand and clay unit of fluvial origin.

The Quaternary sediments can be divided into three units. The surface unit consists of interbedded sand and clay about $30-40 \mathrm{ft}$ thick; the middle unit is silty, sandy clay and organic matter about 36-107 ft thick; and the base unit is gravelly sand and clay about 13-50 ft thick. The Cretaceous sediments consist of interbedded layers of fine-grained sand and massive clay. The top of this layer is at a depth of 110-160 ft. Metamorphic bedrock underlies the sediments at depths ranging from 200 to $900 \mathrm{ft}$.

\subsubsection{Surface Water}

The southern and eastern shores of J-Field are covered by an extensive marsh system (Figure 2.2). The marshes may be flooded during storms and very high tides but are 


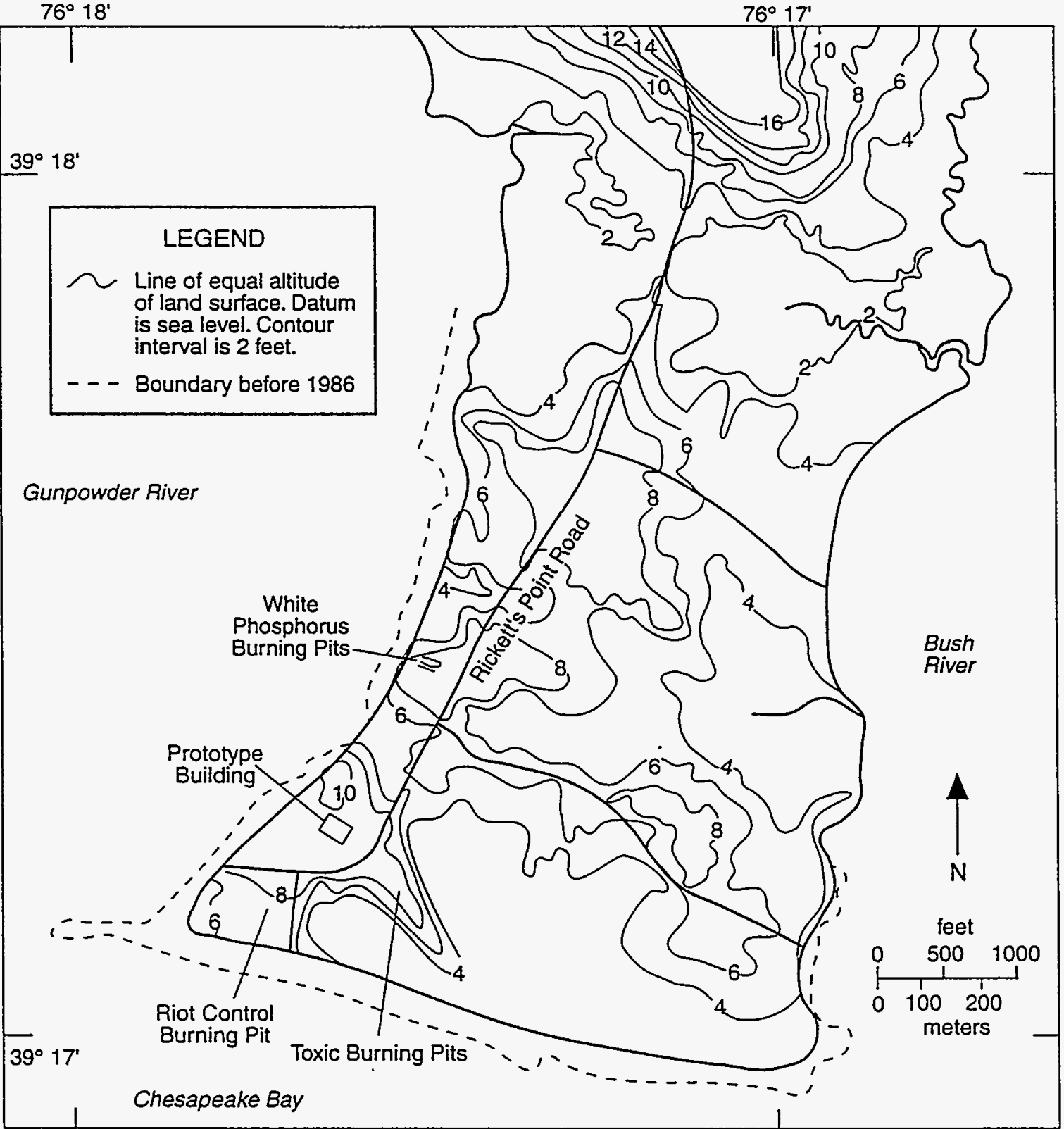

FIGURE 2.1 Topography of the J-Field Area (Source: Adapted from Hughes 1993) 


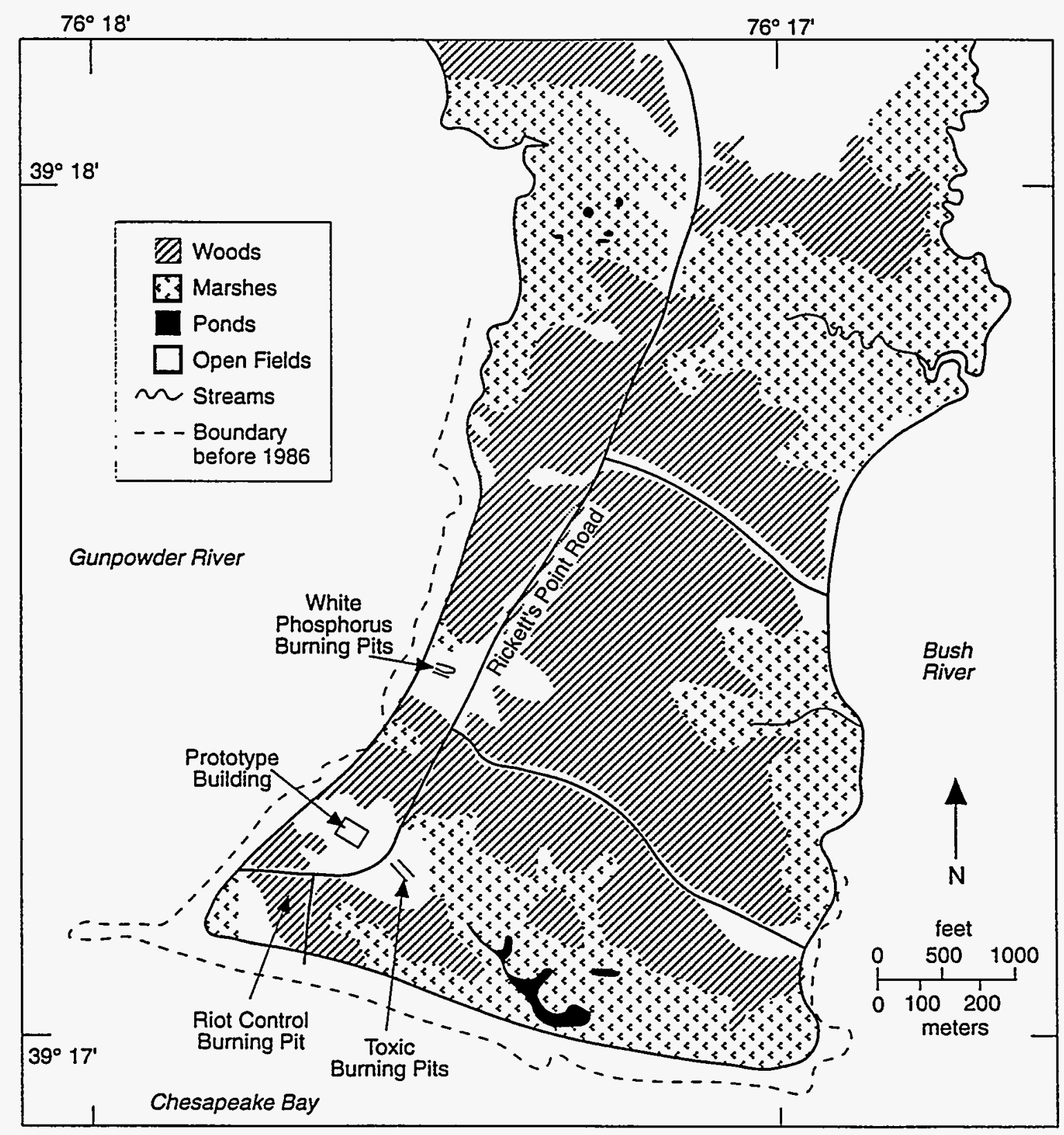

FIGURE 2.2 Locations of Woods, Marshes, Ponds, Open Fields, and Streams at J-Field (Source: Adapted from Hughes 1993) 
not affected by normal tides of $1-2 \mathrm{ft}$. The water level in the marshes is generally about $2 \mathrm{ft}$ above high tide in Chesapeake Bay. The disposal pits at J-Field originally drained into these marshes or into the Gunpowder and Bush rivers. During the 1970s, drainage from the disposal pits was blocked. Currently, surface water can be 1-2 ft deep in the TBP and the WPP during the wet season, generally March to June (Hughes 1993). Several ponds and streams are located within the marshy areas of J-Field (Figure 2.2). The largest pond, which is about $5 \mathrm{ft}$ deep, is southeast of the TBP. Two streams on the eastern side of J-Field are the only on-site streams and do not carry much runoff except during storms.

\subsubsection{Groundwater}

Four major hydrologic units have been identified beneath J-Field - the surficial aquifer (in the overlying Talbot layer), the leaky confining unit (in the middle layer), the confined aquifer (in the bottom Talbot unit), and the Potomac Group aquifer. Groundwater flow in these units is described below on the basis of current knowledge of the aquifers. Groundwater is currently being modeled in these units. The model results are not yet available, but will be presented in the RI report with other results of the RI field investigation.

\subsubsection{Surficial Aquifer}

The surficial aquifer consists of interbedded sand and clay and corresponds to the surface unit of the Quaternary (Talbot) sediment; it ranges from 25 to $40 \mathrm{ft}$ thick, with elevations following the surface topography. The steepest hydraulic gradients were found near the TBP and WPP. Because the closest pumping of this aquifer is about $4 \mathrm{mi}$ to the west, the major influences on the flow system are recharge, evapotranspiration, and tidal fluctuations. Recharge is mainly through rainfall, and the system discharges into the marshes and Chesapeake Bay. Some recharge from Chesapeake Bay may occur during droughts (Hughes 1993). Figure 2.3 shows the direction of groundwater flow in the surficial aquifer.

A general downward gradient that occurs between the water table and the leaky confining layer indicates that the leaky confining unit is recharged primarily by the surficial aquifer. During the summer, the direction of vertical flow is reversed at some locations. Groundwater under the marsh and the rivers, which are discharge areas, probably leaks upward from the leaky confining aquifer into the surficial aquifer.

\subsubsection{Leaky Confining Unit}

The leaky confining unit consists of silty, sandy clay and organic matter and corresponds to the middle unit of the Quaternary (Talbot) sediments. Vertical leakage from 


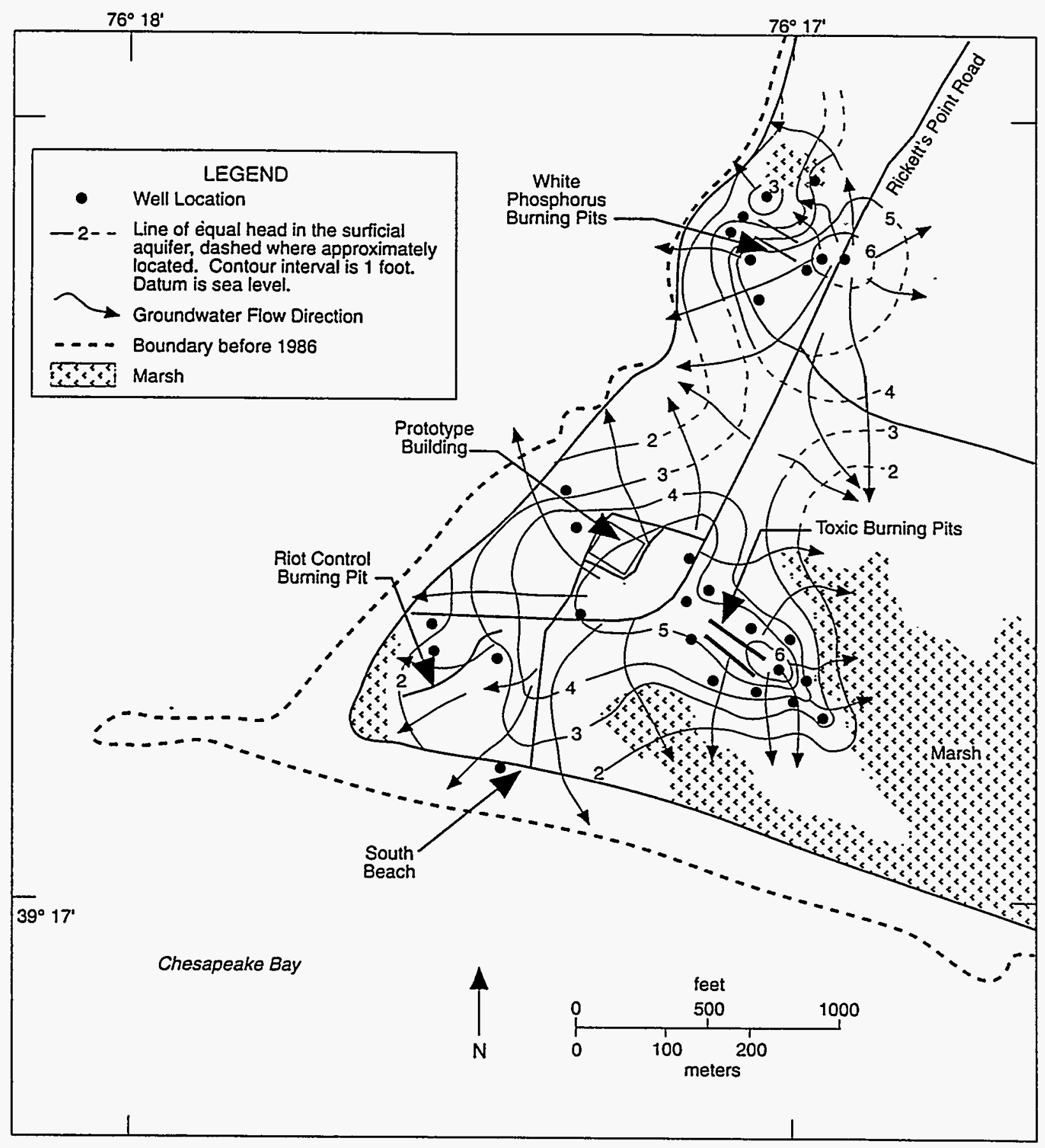

FIGURE 2.3 Groundwater Flow in the Surficial Aquifer, November 1989 (Source: Adapted from Hughes 1993) 
the leaky confining unit to the underlying confined aquifer occurs at all sites beneath J-Field but is probably quite limited offshore. The direction of vertical flow may be reversed in some offshore areas (Hughes 1993).

Lateral flow in the leaky confining unit is generally the same as that of the surficial aquifer. In the western part of the site, the unit is $40 \mathrm{ft}$ thick, with a surface elevation $25 \mathrm{ft}$ below mean sea level (MSL). In the eastern portion of the site, the unit is $107 \mathrm{ft}$ thick and has a surface elevation of $35 \mathrm{ft}$ below MSL. Hydraulic conductivities range from less than 0.01 to $0.20 \mathrm{ft} / \mathrm{d}$, with a median value of $0.05 \mathrm{ft} / \mathrm{d}$ (Hughes 1993).

\subsubsection{Confined Aquifer}

The confined aquifer consists of gravelly sand and clay and corresponds to the base unit of the Quaternary (Talbot) sediments. In the western part of J-Field, the top of the confined aquifer is $60 \mathrm{ft}$ below MSL, and the unit is $50 \mathrm{ft}$ thick. In the southeast, this aquifer dips to a surface elevation of $142 \mathrm{ft}$ below MSL and thins to $15 \mathrm{ft}$ thick. Lateral flow directions are similar to those in the water table; however, the hydraulic head and lateral gradients are very small. Groundwater flows away from the TBP toward the marshes and Chesapeake Bay, and wells show evidence of a tidal influence. Seasonal variations in the flow direction of the confined aquifer occur for short periods during the summer (Hughes 1993).

\subsubsection{Potomac Group Aquifer}

The Potomac Group aquifer consists of interbedded, fine-grained sand and massive clay. This aquifer corresponds to the Cretaceous (Potomac Group) sediments of fluvial origin. Surface elevations of the Potomac Group aquifer range from $105 \mathrm{ft}$ below MSL in the eastern part of J-Field to $157 \mathrm{ft}$ below MSL in the western part. The thickness of the aquifer is, in general, uncertain but may be up to $800 \mathrm{ft}$. The sediments are underlain by metamorphic bedrock. Insufficient data are available to determine lateral or vertical flow directions or the effects of the seasons and tides on the Potomac Group aquifer (Hughes 1993).

\subsubsection{Ecology}

Gunpowder Neck Peninsula consists primarily of open fields (mowed and unmowed grass), bare ground, and second-growth woods (dominated by maple, oaks, and sweetgum). J-Field supports extensive areas of these second-growth woods and freshwater wetlands (dominated by common reed). A large wetland at the southern end of J-Field (Figure 2.2) supports extensive areas of reed and includes a large area of open water. All wetlands at J-Field are separated from the Chesapeake Bay by beach ridges and thus are not directly influenced by tidal fluctuations except through changes in groundwater levels. A few areas of bare ground are located on the western and eastern sides of J-Field, particularly in the vicinity of disposal pits. Additional freshwater tidal and nontidal wetlands occur along the 
periphery of the Gunpowder Neck Peninsula, outside of J-Field. The peninsula is surrounded by freshwater tidal estuaries - Chesapeake Bay to the south, Gunpowder River to the west, and Bush River to the east.

Both the TBP and the WPP AOCs are in open areas cleared of natural vegetation. The area immediately around each pit consists of mowed grass with weeds typical of disturbed habitats and old fields. The TBP are west of a large wetland at the southern end of J-Field. Some of the burned material from these pits has, over time, been pushed into the wetland. The WPP are very close to the Gunpowder River. In 1986, a berm was constructed to prevent waste material from these pits from entering the river. Such material is now diverted into a wetland approximately $100 \mathrm{~m}$ north of the pits. The RCP has not been used since the early 1970s; therefore, it is presently overgrown with shrubs and reeds. It is likely that runoff from the pit enters an adjacent wetland and the Gunpowder River.

The biota at J-Field have not been surveyed in detail; however, common species are likely to include those typical of other areas of the APG. Mammals likely to be common at $J$-Field include the muskrat, raccoon, white-tailed deer, short-tailed shrew, and white-footed mouse. Common birds could include great blue heron and spotted sandpiper. Because of its status as a federal endangered species, the bald eagle (known to occur at J-Field) is of ecological and regulatory interest. Composition of the fish communities in the J-Field wetlands has not been determined. Common species in the surrounding estuary include alewife, American shad, Atlantic menhaden, channel catfish, and white perch.

\subsection{BACKGROUND OF J-FIELD AREAS OF CONCERN}

The following sections summarize the past disposal operations conducted at each $\mathrm{AOC}$ at J-Field. General descriptions of the hydrology and soils in the vicinity of J-Field are also included. PAOCs are addressed in Appendix B.

\subsubsection{Toxic Burning Pits AOC}

The TBP AOC is located on about 9 acres in the southern portion of J-Field (Figure 1.3). Disposal operations at the TBP area began in the 1940s and have continued until the present. The pits were used most extensively between the late 1940s and the 1960s. Items disposed of included chemical agents, bulk chemical wastes, drummed chemical wastes, $\mathrm{HE}$ (by OB/OD), nerve agents, incapacitating agents (also known as riot control agents), chlorinated solvents, and blister agents (Nemeth 1989).

Information from interviews, sampling, and magnetic surveys indicates that five disposal pits were used at the TBP area. The two existing (or main) burning pits (each covering about 4,500 $\mathrm{ft}^{2}$ ) were the pits most actively used for the disposal of various chemical agents and explosives. Three other burning pits, now covered, were used to dispose of VX, dichlorodiethyl sulfide (mustard), and the primary components of liquid smoke - titanium tetrachloride (FM) and sulfur trioxide/chlorosulfonic acid (FS). 
The VX pit and mustard pit are about 100 and $150 \mathrm{ft}$ long, respectively. The liquid smoke disposal pit is fairly small, covering an area of about $24 \mathrm{ft}^{2}$. Liquid smoke was probably disposed of by placing it on the ground and allowing it to vaporize into the atmosphere. HE munitions were also disposed of by detonation in an area along the southeastern edge of the TBP area (Nemeth 1989).

Storage and handling areas have been identified (in aerial photographs) at the upper end of both the VX burning pit and the mustard burning pit. In addition, a square pit approximately $4 \mathrm{ft}$ by $4 \mathrm{ft}$ and $3 \mathrm{ft}$ deep has been identified at the current tree line south of the main burning pits. These storage and handling areas and the pit could be additional sources of contamination in the TBP AOC.

The TBP area is bounded to the northeast by marsh and to the south and southeast by woods and marsh (Nemeth 1989). Because the elevation of the ground surface is highest in the northwestern portion of the TBP area, surface water probably drains toward the southsoutheast into the marsh area. The direction of groundwater flow in the surficial aquifer is probably also toward the marsh. Soils are brownish-yellow silty fine sand at the surface, grading to bluish-gray silty fine sand below a depth of $14 \mathrm{ft}$ (Princeton Aqua Science 1984).

\subsubsection{White Phosphorus Burning Pits AOC}

The WPP AOC is located near the Gunpowder River in the western portion of J-Field (Figure 1.3). The area contains two pits that were used for disposal (by detonation and burning) of white phosphorus (WP), plasticized white phosphorus (PWP), munitions filled with WP, and materials contaminated with WP. After materials were burned and reburned in the pits, debris and soil were pushed out. Some of the materials disposed of at this site probably contained other types of waste in addition to WP. The types and quantities of these other wastes are unknown, although personal interviews indicate that riot control agents may have been disposed of here (Nemeth 1989).

The WPP area has been used as a disposal site since the late 1940s or early 1950s. Aerial photographs show that in 1951, disposal operations were conducted in the southeastern portion of what is currently the open disposal area. The two existing pits were constructed sometime between 1951 and 1957 (Nemeth 1989).

During the late 1950s, the pits were extended to the Gunpowder River. Pushout from the pits was pushed into the river. In 1986, a ditch was excavated to drain water from the pits. The ditch from the northern pit extends north toward a bermed depression that was constructed to hold the water. The ditch associated with the southern pit ends at what is assumed to be a pushout area. During wet weather, water collects in the pits and the bermed depression, even though surface runoff does not enter the pits (Nemeth 1989; Sonntag 1991). As previously noted, the WPP is considered an active emergency disposal facility. As a result, the existing pits and areas potentially affected by emergency disposal operations have been excluded from the RI/FS and are deferred pending the relocation of emergency disposal operations. However, aerial photograph interpretation indicates that two 
suspect burning areas may have existed northwest and southwest of the WPP and that a storage area may have existed southeast of the WPP. These areas could represent sources of contamination and are not likely affected by current operations. As a result, these areas will be addressed in this RI.

Surface water drainage from the WPP area flowed west into Gunpowder River. The direction of groundwater flow in the surficial aquifer is also probably toward Gunpowder River to the west (Nemeth 1989). Soils are brownish-yellow silty fine sand at the surface, grading to bluish-grey silty fine sand below a depth of $14 \mathrm{ft}$ (Princeton Aqua Science 1984).

\subsubsection{Riot Control Burning Pit AOC}

The RCP AOC is located in a heavily wooded area in the southwestern portion of J-Field (Figure 1.3). Except for a small area in the northeastern part of the site, the area is overgrown with vegetation. About $30 \mathrm{ft}$ of an access road has been eroded, and the presence of several fallen trees about $10 \mathrm{ft}$ offshore indicates that this area is rapidly being eroded by wave action.

Disposal operations in the pit began in the late 1940s and continued until operations at the site ceased in the early 1970s. The area immediately east of the access road to the South Beach was probably part of the site and may have been used for burning operations during the 1950s. A trench was excavated in the area sometime between 1957 and 1960 and was later extended southwest to the Gunpowder River to provide drainage from the pit. Between 1960 and the early 1970s, the trench was used for burning riot control agents, munitions filled with riot control agents, and material contaminated with these agents (Nemeth 1989). The main agent disposed of was the tear agent o-chlorobenzylidene malononitrile (CS); some chloroacetophenone (CN) was also disposed of there (Sonntag 1991).

Surface water drainage from the RCP area flows toward the southwest into a small marsh area and the Gunpowder River. The direction of groundwater flow in the surficial aquifer is probably toward the marsh and Gunpowder River to the west-southwest. Shallow soils are predominantly clayey sandy silt (Nemeth 1989).

\subsubsection{Prototype Building AOC}

The PB AOC is located in the southwestern portion of J-Field, northwest of the TBP area and north of the RCP area (Figure 1.3). The building, constructed during World War II, is an open-sided, three-level reinforced concrete structure. It was originally used for testing the effectiveness of bombs. Since World War II, the PB and the areas to the west and north have been intermittently used for temporary storage of solid waste (Nemeth 1989). Two suspect burning areas have also been identified - one northeast and one west of the $\mathrm{PB}-$ on the basis of a review of archival information. 
The area around the PB is fairly flat; surface water drains primarily west toward a marsh area (Nemeth 1989) but may also flow north-northwest toward the Gunpowder River. The direction of groundwater flow in the surficial aquifer is probably toward Chesapeake Bay. The shallow soils are predominantly silty, clayey sand with greater amounts of clay and silt near the surface (Nemeth 1989).

\subsubsection{South Beach Demolition Ground AOC}

The SBDG AOC was located along the southern beach of J-Field (Figure 1.3). The area was used as a demolition site for HE munitions during the 1960s and 1970s, and possibly during the 1950s (Nemeth 1989). Munitions were detonated either on the surface or under several feet of soil. It is reported that remnants of munitions detonated in this area are currently visible about $100 \mathrm{ft}$ offshore during low tide. At high tide, most of the demolition ground area is 1-2 ft below water. A few demolition craters, which are assumedly remnants of the SBDG operations, are visible just inland from the shoreline and east of the end of Rickett's Point Road.

Surface water from the remnants of the SBDG most likely drains south toward Chesapeake Bay. The direction of groundwater flow in the surficial aquifer is probably toward the bay as well. The nature of the shallow soils in the SBDG is undocumented; however, they are most likely composed of clayey sandy silt, similar to the SBT area.

\subsubsection{South Beach Trench AOC}

The SBT AOC is located near the southern beach of J-Field, southeast of the RCP area (Figure 1.3). The trench, about $75 \mathrm{ft}$ long and $12 \mathrm{ft}$ wide, was excavated between 1957 and 1960. It may have been a borrow pit for nearby demolition activities. Aerial photographs from the 1960s reveal a road leading into and out of the SBT. No information has been found regarding past chemical or hazardous material disposal in this area; however, chemical analyses of soil samples collected from the trench during the RFA showed low levels of chlordane and naphthalene (Nemeth 1989).

Surface water drainage from the SBT is primarily west toward a marsh area (Nemeth 1989), but surface water may also flow south toward Chesapeake Bay. Groundwater in the surficial aquifer probably flows toward Chesapeake Bay. Shallow soils are predominantly clayey sandy silt (Nemeth 1989).

\subsubsection{Robins Point Demolition Ground AOC}

The RPDG AOC is in the eastern portion of J-Field close to the Bush River (Figure 1.3). The site was first used during the late 1970s for the destruction of HE and HE-filled munitions. The site was also reportedly used during the 1980s for destruction of small amounts of sensitive and unstable chemicals by detonation with explosives (Nemeth 1989). 
The original site, now inactive and considered an AOC for the purposes of the RI/FS activities, was a small clearing near the edge of the adjacent marsh. In 1985, the clearing was enlarged, and a berm was built on the western edge of the clearing. Liater demolition activities occurred in an area west of the berm; the berm prevented surface runoff from entering the marsh (Nemeth 1989). The area west of the berm has remained active and continues to be used for disposal operations.

Before 1985, surface water drainage from the RPDG flowed directly into the adjacent marsh to the east. The berm constructed in 1985 now prevents runoff from directly entering the marsh. However, water that ponds west of the berm seeps through the berm to the inactive portion of the RPDG. Groundwater in the surficial aquifer probably flows to the east toward the marsh. Shallow soils in the RPDG consist predominantly of clayey silt (Nemeth 1989).

\subsubsection{Robins Point Tower Site AOC}

The RPTS AOC is located near Robins Point at the southeastern tip of the Gunpowder Peninsula (Figure 1.3). The wooden observation tower was built between 1957 and 1960. The road connecting Robins Point with Rickett's Point Road has existed since about 1917, when APG became an army installation. However, aerial photographs suggest that the area was not used until the 1950s. The Robins Point area was used for launching and observing rockets (Nemeth 1989).

Around 1959, the Robins Point area may have been used for at least one test burn of wood contaminated with radioactive material (including radium and strontium). According to Nemeth (1989), the test burn was to be conducted in a trench (20 ft long, $5 \mathrm{ft}$ wide, and $5 \mathrm{ft}$ deep), with not more than $500 \mathrm{lb}$ of material to be burned in small increments. A 1959 U.S. Army Environmental Hygiene Agency (USAEHA) report recommended that the routine burning of radioactively contaminated materials be conducted in a closed incinerator; correspondence in the USAEHA project file indicates that this recommendation was accepted (Nemeth 1989). The possibility remains, however, that a test burn of radioactively contaminated wood did occur at either the RPDG or the RPTS. Records do not indicate which site was used. However, it is likely that the RPTS was used because the site of the demolition ground was wooded and not yet in use in 1959. In addition, aerial photographs from the 1960s show no roads or open areas at the site of the RPDG.

Surface water from the RPTS probably flows east toward Bush River and south toward the adjacent marsh. Groundwater in the surficial aquifer probably also flows toward Bush River and the marsh. The shallow soils are predominantly sand, with sandy clayey silt near the surface (Nemeth 1989). 


\subsubsection{Other J-Field Sites}

Pursuant to the requests of the Maryland Department of the Environment (MDE), investigative activities have been expanded beyond the eight specified AOCs to include all of J-Field. As a result, a protocol was developed to identify other suspect areas, referred to as PAOCs, on the basis of a review of archival information and walkover surveys. The process used to identify the PAOCs and the sampling activities proposed for the PAOCs are described in Appendix B.

\subsection{PRELIMINARY EVALUATION OF J-FIELD AREAS OF CONCERN}

Several investigations have been conducted at J-Field to characterize contamination from past operations, install monitoring wells, and characterize the estuarine sediments around the peninsula. Table 2.1 provides a chronological summary of these studies. An overview of the results of these studies is presented in the following sections. These sections present data for J-Field that were collected through January 1993. All data corrected during the RI will be presented in technical updates and the RI report.

\subsubsection{Toxic Burning Pits}

\subsubsection{Types of Waste Present}

The TBP were used to dispose of HE-filled munitions, nerve agents, mustard agents, chemical warfare agents (CWAs), decontaminating agents, liquid smoke, chlorinated solvents, and radioactive chemicals. In addition, fuel was used to ignite materials placed in the pits.

\subsubsection{Types of Contaminants Present}

A hydrological assessment of J-Field was carried out in two phases by the USGS. Phase I was conducted from 1987 to 1992 to select locations for establishing monitoring wells at the TBP and WPP areas. It was assumed that the pits and the open burning grounds around them were the primary sources of contamination in the area. The goal of Phase II, conducted in 1992, was to determine the extent of contamination in the area of the TBP, sample the RCP area, and determine if contaminated groundwater was moving into Chesapeake Bay (Hughes 1993). The following subsections discuss the findings relative to the nature and extent of contamination in the TBP area.

\section{Soil Gas}

During Phase I of the hydrological assessment, the USGS sampled 37 locations around the TBP for soil-gas concentrations of trichloroethylene (TRCLE), tetrachloroethylene (TCLEE), alkanes, combined hydrocarbons, and simple aromatics. The relative contours for all contaminants except the alkanes show a broad band of contamination that extends across 
TABLE 2.1 Summary of Previous Investigations at J-Field

\begin{tabular}{|c|c|c|c|}
\hline Field Investigation & Investigator & Date & Objective/Activity \\
\hline $\begin{array}{l}\text { Environmental } \\
\text { Contamination Survey }\end{array}$ & USATHAMA & $1977-1978$ & $\begin{array}{l}\text { Conducted to determine if contamination from past } \\
\text { operations was migrating off-post. Eleven monitoring wells } \\
\text { (TH1-11) were installed in the surficial aquifer }-10 \text { near the } \\
\text { TBP and WPP and } 1 \text { near the Robins Point Tower. Ground- } \\
\text { water samples were collected and analyzed. }\end{array}$ \\
\hline Munitions Disposal Study & $\begin{array}{l}\text { Princeton Aqua } \\
\text { Science }\end{array}$ & 1983 & $\begin{array}{l}\text { Installed nine monitoring wells (P1-9) in the surficial } \\
\text { aquifer - five near the TBP and four near the WPP. } \\
\text { Composite soil samples were collected during drilling of wells } \\
\text { Soil samples were also collected from the pits in the TBP and } \\
\text { WPP areas. }\end{array}$ \\
\hline $\begin{array}{l}\text { RCRA Facility } \\
\text { Investigation }\end{array}$ & USAEHA & 1986 & $\begin{array}{l}\text { Sampled groundwater from TH and P series wells. Soil } \\
\text { samples also collected in and around the pits in the TBP, } \\
\text { WPP, and RCP areas and near the Prototype Building. A } \\
\text { field radiation survey was also performed. }\end{array}$ \\
\hline $\begin{array}{l}\text { Hydrological Assessment, } \\
\text { Phase I }\end{array}$ & USGS & 1987-1992 & $\begin{array}{l}\text { Drilled exploratory boreholes, collected soil samples, and ran } \\
\text { geophysical logs. Installed } 12 \text { well clusters (JF1-12), each } \\
\text { consisting of } 3 \text { wells screened in the upper portions of the } \\
\text { confined aquifer, the confining unit, and surficial aquifer. } \\
\text { Wells were sampled on a monthly (1987) and quarterly } \\
\text { basis (1989-1992); water-level measurements also taken. } \\
\text { Conducted slug tests. Currently using MODFLOW model to } \\
\text { simulate contaminant pathways in groundwater. A total of } \\
21 \text { surface samples also collected from Gunpowder River and } \\
\text { Chesapeake Bay. Soil and soil-gas samples collected in TBP } \\
\text { and WPP areas. }\end{array}$ \\
\hline
\end{tabular}


TABLE 2.1 (Cont.)

\begin{tabular}{|c|c|c|c|}
\hline Field Investigation & Investigator & Date & Objective/Activity \\
\hline $\begin{array}{l}\text { Characterization and } \\
\text { Interim Remediation }\end{array}$ & $\begin{array}{l}\text { Roy F. Weston, } \\
\text { Inc. }\end{array}$ & 1992 & $\begin{array}{l}\text { Activities included topographic survey of J-Field area; survey } \\
\text { of UXO } \mathrm{O}^{\mathrm{a}} \text { in each burning pit and along shoreline of WPP and } \\
\text { RCP; construction of access roads; placement of riprap and } \\
\text { gabion structures along WPP and RCP shoreline; removal } \\
\text { and staging of surface material and debris from burning pit } \\
\text { areas; sampling and staging drums from the Prototype } \\
\text { Building; sampling and analysis of soil from the pits and } \\
\text { pushout areas; installation of flood control berms in the pit } \\
\text { areas, where needed; and collection of surface and subsurface } \\
\text { soil samples. }\end{array}$ \\
\hline $\begin{array}{l}\text { Hydrological Assessment- } \\
\text { Phase II }\end{array}$ & USGS & 1992 & $\begin{array}{l}\text { Continued sampling of groundwater, measuring water levels } \\
\text { in all monitoring wells, and slug testing. Four new wells } \\
\text { installed. Collected surface water samples from marsh areas } \\
\text { and estuaries surrounding J-Field, based on thermal imagery } \\
\text { studies conducted by the USGS. }\end{array}$ \\
\hline Sediment Sampling Study & EPA & 1992 & $\begin{array}{l}\text { Conducted a study to characterize the estuarine sediments } \\
\text { around the Gunpowder Neck Peninsula. }\end{array}$ \\
\hline
\end{tabular}

a UXO = unexploded ordnance. 
the eastern end of the pits from the marsh on the north to the marsh on the south (Figure 2.4). The alkanes appear to be limited to the area south of the TBP, and the data suggest a plume of contamination moving into the marsh at the southern edge (Figure 2.5) (Hughes 1993).

Additional soil-gas samples were collected during Phase $I I$ from wooded and marshy areas north and south of the TBP and from 15 locations along Chesapeake Bay. Samples were analyzed for combined dichloroethylenes (DCEs) and trichloroethanes (TCEs), combined TRCLEs and TCLEEs, phthalates, and heavy aromatic hydrocarbons (Hughes 1993).

Relative values and contours for concentrations of combined DCE and TCE and of combined TRCLE and TCLEE show a similar distribution, with elevated contamination to the southeast of the TBP. Figure 2.6 shows contours for combined TRCLE and TCLEE. The DCE plus TCE contamination south of the pits is somewhat more extensive, with elevated values extending to the shore of Chesapeake Bay. The concentration contours, when combined with contours from Phase I analyses, suggest that plumes of contaminated groundwater are moving downgradient under the marshes both on the northern and southern sides of the TBP. This hypothesis is supported by the relative contours for heavy aromatics (Figure 2.7), which show locations with more extensive contamination, including along the shore. The data also suggest that contaminated groundwater may be moving beneath, and possibly discharging into, the bay, or that contaminated surface water from the marshes may be moving into shore sediments (Hughes 1993).

\section{Soil}

In 1983, soil samples were collected during the installation of monitoring wells at the TBP. Four composite samples were collected at depth intervals of $5 \mathrm{ft}$. The samples were analyzed for metals, cyanide, phenols, total phosphorus, volatile organic compounds (VOCs), pesticides, polychlorinated biphenyls (PCBs), and herbicides. Some of the results are listed in Table 2.2. The data showed elevated concentrations of lead, zinc, nitrate, and petroleum hydrocarbons in each of the samples. It should be noted that the background samples also contained somewhat elevated concentrations of petroleum hydrocarbons.

During the 1986 RFA (Nemeth 1989), surface soil samples were collected from 20 locations in the TBP and the debris pushout area (Figure 2.8). All of the samples were analyzed for metals, extractable metals, and explosives-related compounds. The results, as summarized in Table 2.3, show that the surface soil in and around the TBP contain elevated levels of metals, especially lead (up to $2.6 \%$ in the pushout area [location 12]); mercury (up to $10.8 \mathrm{mg} / \mathrm{kg}$ in one of the pits [location 8]); and cadmium (16.6 mg/kg at location 20). Samples from locations 7 and 12 exceeded the RCRA extraction procedure (EP) limit of $5.0 \mathrm{mg} / \mathrm{L}$ for lead (40 CFR 261). 


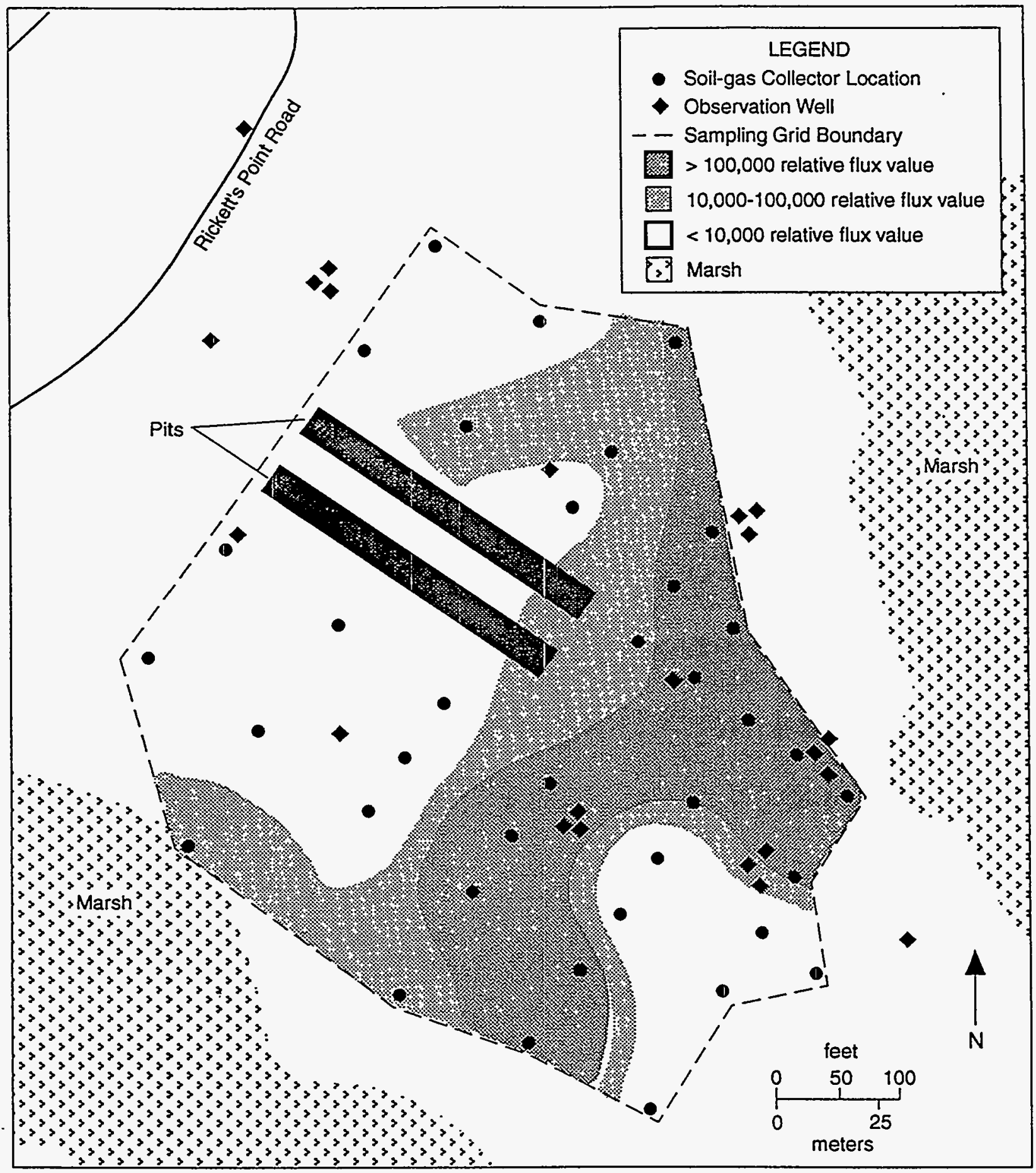

FIGURE 2.4 Relative Contours for all Soil-Gas Parameters (except alkanes) at the Toxic Burning Pits Area (Source: Adapted from Hughes 1993) 


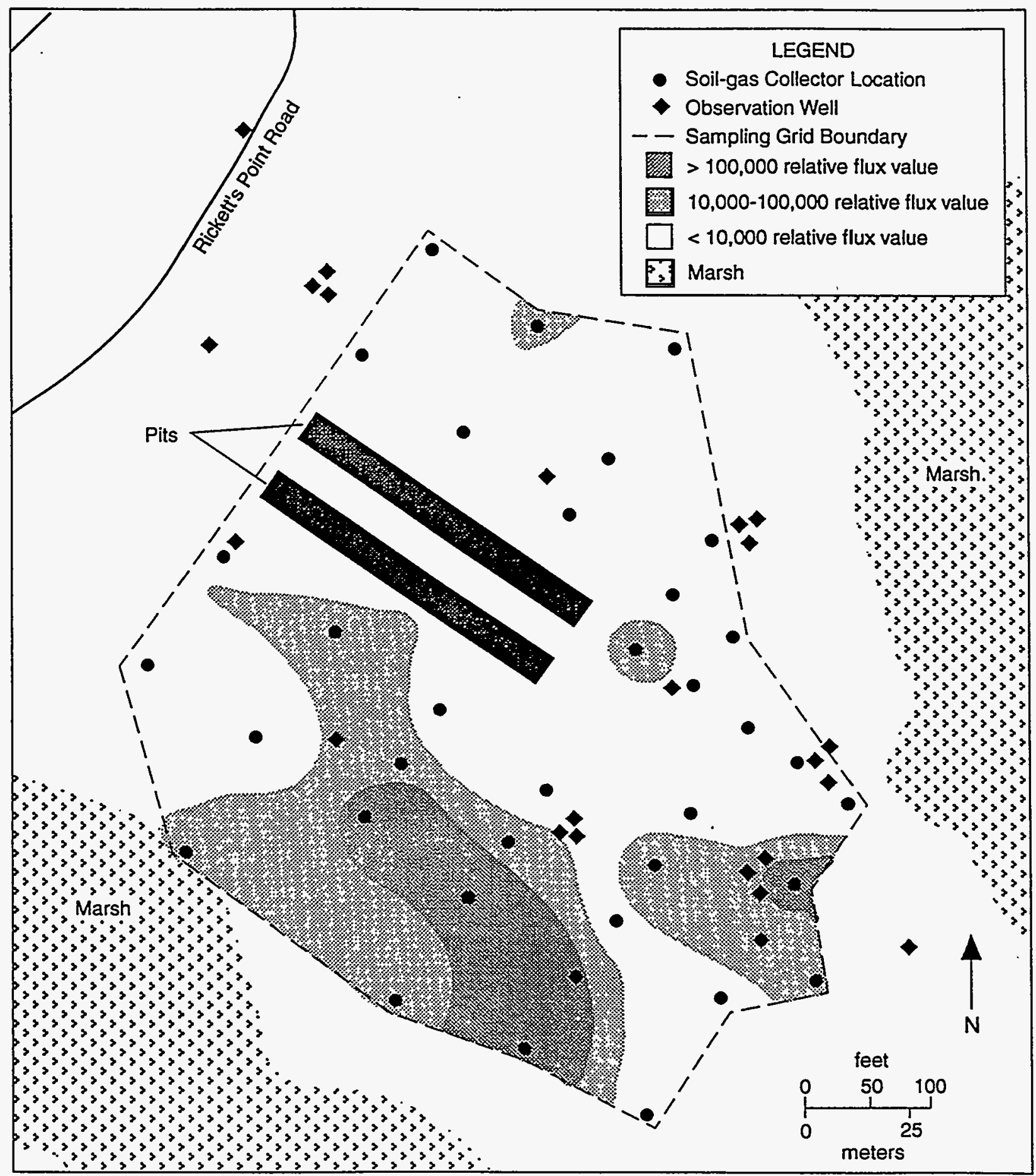

FIGURE 2.5 Relative Contours for Alkanes in Soil Gas from the Toxic Burning Pits Area (Source: Adapted from Hughes 1993) 


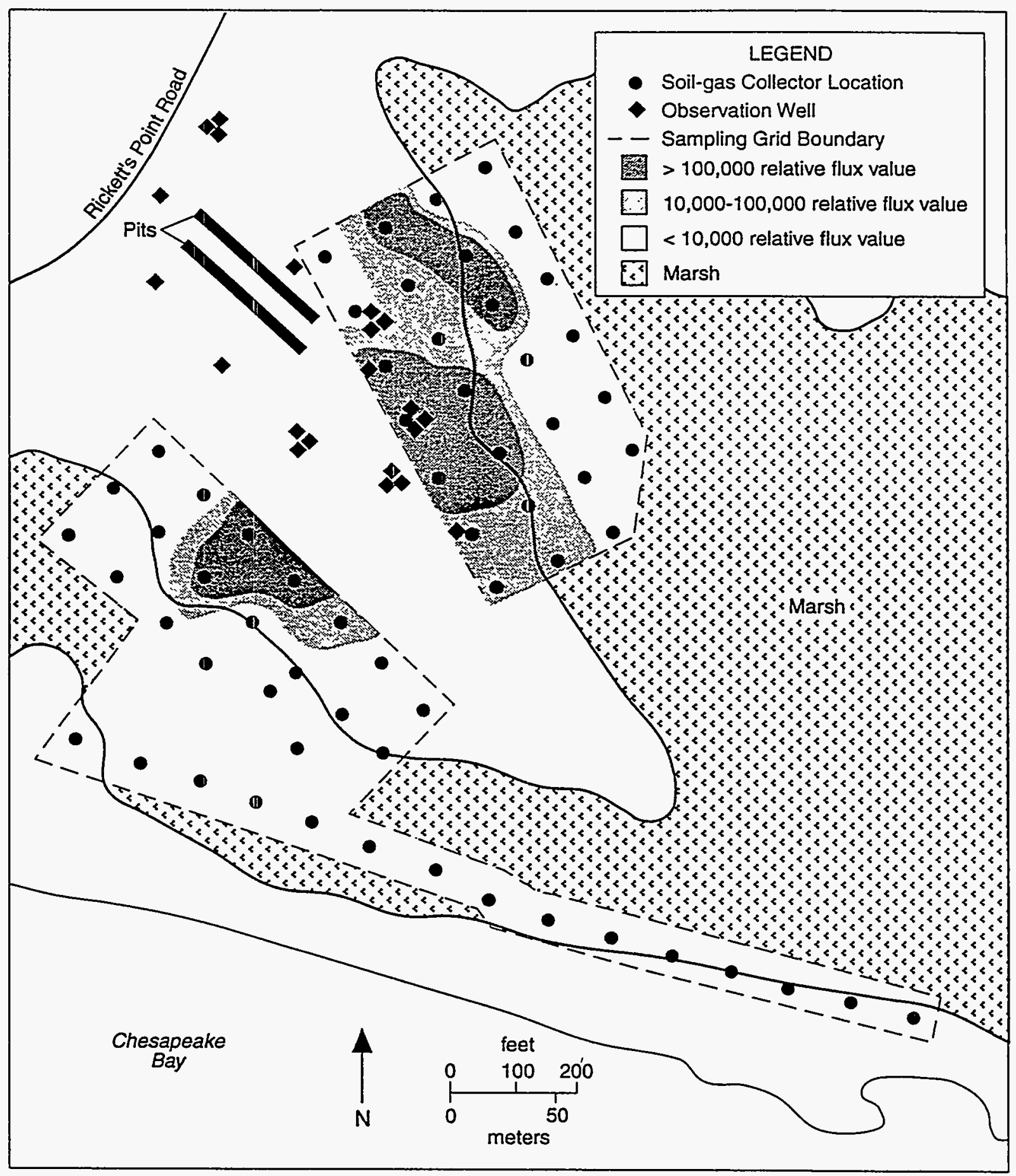

FIGURE 2.6 Relative Contours for Combined TRCLE and TCLEE at the Toxic Burning Pits Area (Source: Adapted from Hughes 1993) 


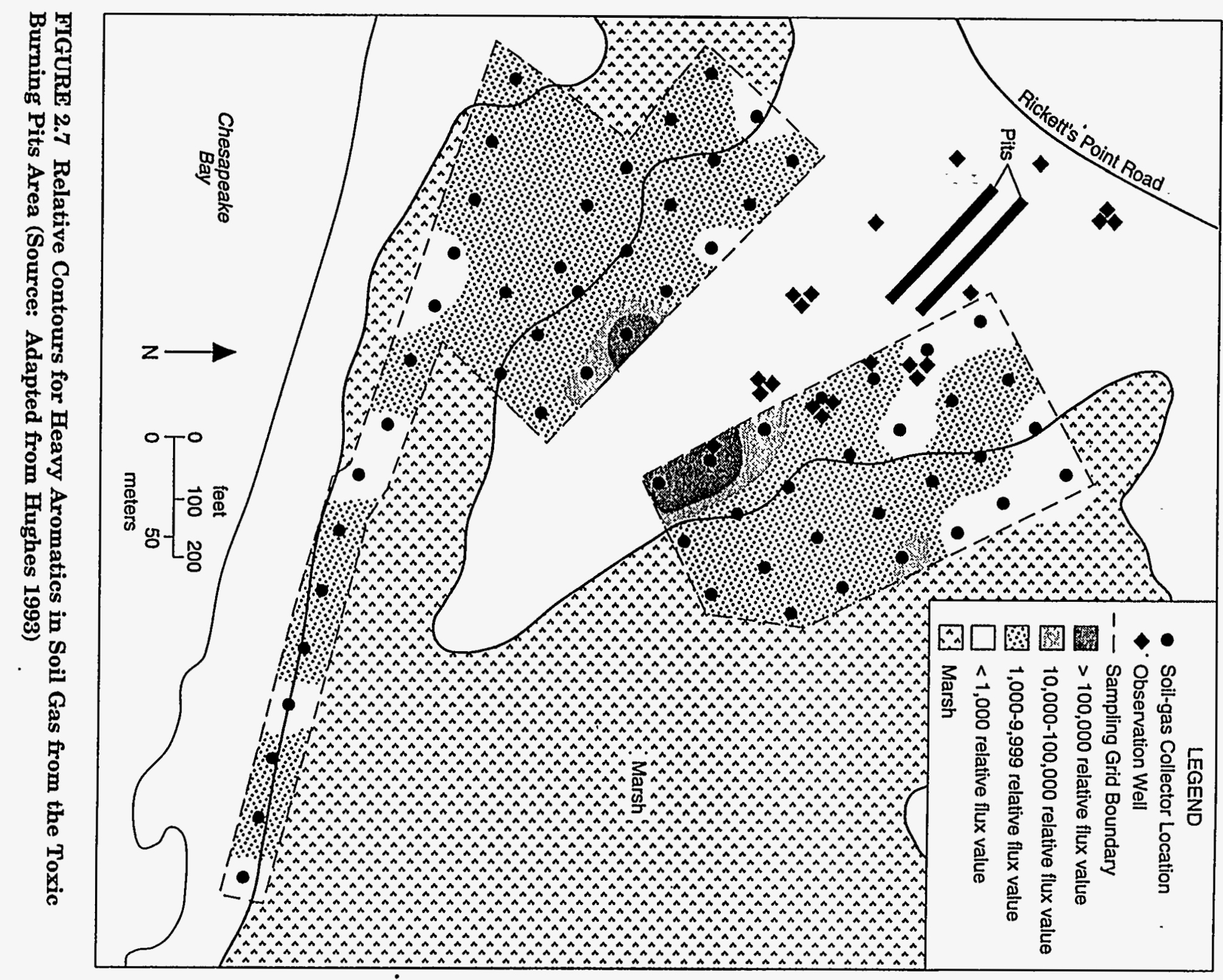


TABLE 2.2 Analytical Results for Analysis of Soil Samples from the Toxic Burning Pits AOC Main Burning Pits, January 1983

\begin{tabular}{|c|c|c|c|}
\hline \multirow[b]{2}{*}{ Parameter $^{a}$} & \multicolumn{3}{|c|}{$\begin{array}{l}\text { Parameter Concentrations } \\
\text { (mg/kg except as noted) }\end{array}$} \\
\hline & Background ${ }^{b}$ & Pit $1^{c}$ & Pit $2^{\mathrm{c}}$ \\
\hline Arsenic & $<0.481$ & 3.56 & $<0.53$ \\
\hline Barium & 110 & 247 & 257 \\
\hline Cadmium & 0.84 & 4.46 & 2.19 \\
\hline Chromium & 74.70 & 413 & 192 \\
\hline Iron & 6,000 & 18,900 & 17,000 \\
\hline Lead & 76.90 & 717 & 281 \\
\hline Manganese & 153 & 169 & 206 \\
\hline Mercury & 0.034 & 0.080 & 0.008 \\
\hline Potassium & 857 & 1,450 & 1,650 \\
\hline Zinc & 250 & 1,510 & 810 \\
\hline pH (standard units) & 6.30 & 8.50 & 8.80 \\
\hline Nitrate & 295 & 316 & 249 \\
\hline Total phosphorus & 9.00 & $<0.50$ & $<0.25$ \\
\hline Cyanide & $<0.50$ & $<0.50$ & $<0.50$ \\
\hline $\begin{array}{l}\text { Petroleum } \\
\text { hydrocarbons }\end{array}$ & 113 & 800 & 850 \\
\hline Phenols & 0.37 & $<0.13$ & 0.31 \\
\hline Toluene $(\mu \mathrm{g} / \mathrm{kg})$ & $<20.00$ & 32.00 & 28.00 \\
\hline Ethylbenzene ( $\mu \mathrm{g} / \mathrm{kg}$ ) & 20.00 & $<20.00$ & $<20.00$ \\
\hline
\end{tabular}

a Table lists all parameters detected at least once.

b Locations of background samples not given.

c Based on available information, it is inferred that Pit 1 is the northern main burning pit and Pit 2 is the southern main burning pit.

Source: Adapted from Princeton Aqua Science (1984). 


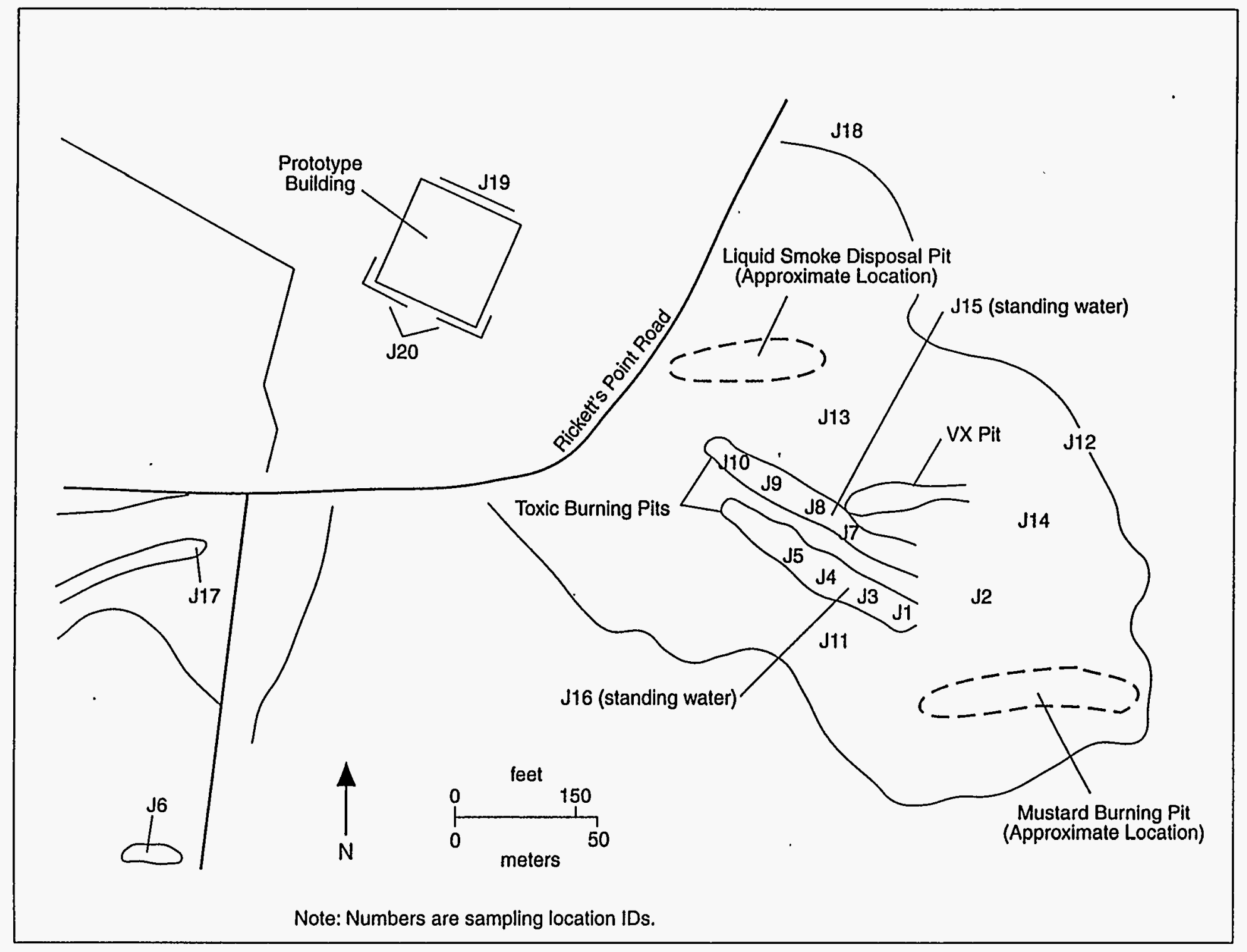

FIGURE 2.8 Locations in the Toxic Burning Pits Area where Surface Soil and Surface Water Samples Were Collected during the 1986 RCRA Facility Assessment (Source: Adapted from Nemeth 1989) 
TABLE 2.3 Analytical Results for Analysis of Soil Samples J1-J20 from the Toxic Burning Pits, 1986

\begin{tabular}{|c|c|c|c|c|c|c|c|c|c|}
\hline Parameter $^{\mathrm{a}}$ & J1 & $\mathrm{J} 2^{\mathrm{b}}$ & J3 & J4 & J5 & J6 & J7 & J8 & J9 \\
\hline \multicolumn{10}{|c|}{ Total Metals (mg/kg) } \\
\hline Arsenic & 54.8 & 25.2 & 21.5 & 40.5 & 18.5 & 9.7 & 47.3 & 25.7 & 43.9 \\
\hline Barium & 592 & 277 & 313 & 90.5 & 134 & $<60$ & 488 & 172 & 296 \\
\hline Cadmium & 8.13 & 4.57 & 2.52 & 4.88 & 1.58 & 2.20 & 17.3 & 8.64 & 6.10 \\
\hline Chromium & 75.5 & 54.4 & 45.9 & 95.9 & 70.8 & 10.7 & 73.3 & 76.0 & 53.3 \\
\hline Lead & 472 & 548 & 378 & 85.3 & 60.3 & 38.5 & 2,998 & 720 & 1,369 \\
\hline Mercury & 0.78 & 0.87 & 0.46 & 0.15 & 0.22 & 0.17 & 2.16 & 10.8 & 7.29 \\
\hline Silver & 14.0 & $<5.0$ & $<5.0$ & 12.1 & $<5.0$ & $<5.00$ & 15.2 & 7.01 & $<5.0$ \\
\hline \multicolumn{10}{|c|}{ Extractable Metals (mg/L) } \\
\hline Cadmium & $<0.10$ & $<0.10$ & $<0.10$ & $<0.10$ & $<0.10$ & $<0.10$ & 0.228 & $<0.10$ & $<0.10$ \\
\hline Lead & $<0.50$ & $<0.50$ & $<0.50$ & $<0.50$ & $<0.50$ & $<0.50$ & 5.23 & $<0.50$ & $<0.50$ \\
\hline \multirow[t]{3}{*}{ Silver } & $<0.50$ & $<0.50$ & $<0.50$ & $<0.50$ & $<0.50$ & $<0.50$ & $<0.50$ & $<0.50$ & $<0.50$ \\
\hline & \\
\hline & $\mathrm{J} 10$ & J11 & J12 & J13 & J14 & J17 & J18 & J19 & $\mathrm{J} 20$ \\
\hline \multicolumn{10}{|c|}{ Total Metals (mg/kg) } \\
\hline Arsenic & 32.2 & 12.6 & 24.1 & 8.26 & 28.7 & 15.9 & 6.5 & 9.74 & 12.3 \\
\hline Barium & 208 & 101 & 855 & 107 & 256 & $<60$ & 81.4 & $<60$ & $<60$ \\
\hline Cadmium & 4.75 & 0.27 & 3.57 & 1.01 & 1.47 & 5.02 & $<0.20$ & 5.38 & 16.6 \\
\hline Chromium & 58.0 & 12.1 & 80.1 & 19.2 & 30.4 & 63.9 & 6.65 & 15.4 & 13.5 \\
\hline Lead & 4,101 & 15.8 & 26,040 & 41.8 & 1,522 & 203 & 12.1 & 140 & 1,622 \\
\hline Mercury & 6.10 & 0.11 & 0.77 & 0.11 & 0.59 & 0.20 & $<0.10$ & 0.28 & 3.40 \\
\hline Silver & $<5.0$ & $<5.0$ & $<5.0$ & $<5.0$ & $<5.0$ & 8.64 & $<5.0$ & $<5.0$ & $<5.0$ \\
\hline \multicolumn{10}{|c|}{ Extractable Metals (mg/L) } \\
\hline Cadmium & $<0.10$ & $<0.10$ & $<0.10$ & $<0.10$ & $<0.10$ & $<0.10$ & $<0.10$ & $<0.10$ & 0.112 \\
\hline Lead & $<0.50$ & $<0.50$ & 31.2 & $<0.50$ & $<0.50$ & $<0.50$ & $<0.50$ & $<0.50$ & $<0.50$ \\
\hline Silver & $<0.50$ & $<0.50$ & $<0.50$ & $<0.50$ & 0.154 & $<0.50$ & $<0.50$ & $<0.50$ & $<0.50$ \\
\hline
\end{tabular}

a Includes parameters that were detected in at least one soil sample.

b VOCs were measured in sample J2 only; 1,000 $\mathrm{\mu g} / \mathrm{kg}$ TRCLE and traces of other VOCs were found.

Source: Nemeth (1989). 
Composite samples from locations 1 and 2 contained 13,000 $\mu \mathrm{g} / \mathrm{kg}$ heptachlor epoxide and lower concentrations of other pesticides. Aroclor 1248 (a PCB) was detected at a concentration of $230,000 \mu \mathrm{g} / \mathrm{kg}$. Composites from locations 3 through 5, 7 through 10,19 , and 20 (near the $\mathrm{PB}$ ) also contained pesticides $-1,000 \mu \mathrm{g} / \mathrm{kg}$ each dichlorodiphenyldichloroethane (DDD), dichlorodiphenyldichloroethylene (DDE), and dichlorodiphenyltrichloroethane (DDT) (in locations 19 and 20 only); and $3,700 \mu \mathrm{g} / \mathrm{kg}$ PCBs (locations 3 through 5 only). Hughes (1993) states that detection of pesticides in samples containing PCBs may represent false positives. PCBs reportedly were used as heat-transfer fluids at the Edgewood Area and disposed of at J-Field (Nemeth 1989). Trace concentrations of organic compounds were also detected in samples: TRCLE (at 1,000 $\mathrm{\mu g} / \mathrm{kg}$ ) and traces of other VOCs in the sample from location 2 , the only sample analyzed for VOCs.

Soil samples were collected by the USGS from depths of approximately $1 \mathrm{ft}$ below land surface at 36 sites in J-Field, including the TBP area (Figure 2.9). The samples were analyzed for indicator parameters, metals, VOCs, semivolatile compounds, and explosives (Hughes 1992). The results of these analyses, except for explosives, are presented in Table 2.4. Soil samples showed some metals contamination, especially at locations 39 and 30 , north of the Mustard Pit. Traces of organic compounds were also detected in some samples.

Soil samples were also collected in the TBP area by Weston in October 1992 (Figure 2.10). The samples were collected at depths of 2,4 , and $6 \mathrm{ft}$ in the pits; and at depths of $3 \mathrm{in}$. and $1 \mathrm{ft}$ in the marshes and pushout areas. Tables 2.5 and 2.6 summarize the analytic results for parameters detected in some of these samples.

The highest concentrations of organic compounds were found in the area of the Mustard Pit: TCLEA, up to 3,270,000 $\mu \mathrm{g} / \mathrm{kg}$ at $6 \mathrm{ft} ; 1,1,2$-trichloroethane (112TCE), up to $8,500 \mu \mathrm{g} / \mathrm{kg}$ at $6 \mathrm{ft}$; TCLEE, up to $25,700 \mu \mathrm{g} / \mathrm{kg}$ at $6 \mathrm{ft}$; and trichloroethene, up to $263,000 \mu \mathrm{g} / \mathrm{kg}$ at $6 \mathrm{ft}$. Organic compounds, including TCLEA, 112TCE, acetone methylene chloride, and TRCLE, were detected in the main burning pits (see Table 2.6). High levels of PCBs were detected in the southern main pit (up to $143,000 \mu \mathrm{g} / \mathrm{kg}$ at $2 \mathrm{ft}$ ), the mustard pit (up to $178 \mu \mathrm{g} / \mathrm{kg}$ at $6 \mathrm{ft}$ ), the southern marsh (up to $3,200 \mu \mathrm{g} / \mathrm{kg}$ at $1 \mathrm{ft}$ ), and the pushout area northwest of the main pits (up to $3,800 \mu \mathrm{g} / \mathrm{kg}$ at $1 \mathrm{ft}$ ). The highest concentrations of lead were found in the southern main pit ( $340 \mathrm{mg} / \mathrm{kg}$ at $2 \mathrm{ft}$ ), the mustard pit (121 mg/kg at $6 \mathrm{ft}$ ), the southern marsh - $(542 \mathrm{mg} / \mathrm{kg}$ at $1 \mathrm{ft})$, the marsh east of the main pits $(79,800 \mathrm{mg} / \mathrm{kg}$ at $3 \mathrm{in}$.$) , and the pushout area northwest of the main pits (1,180 \mathrm{mg} / \mathrm{kg}$ at $3 \mathrm{in}$.).

\section{Surface Water}

Surface water samples (J15 and J16) were collected from the TBP area as part of the 1986 RFA (Nemeth 1989). Sampling locations are shown in Figure 2.8. Samples were analyzed for metals, explosives-related compounds, inorganic compounds, gross alpha, gross beta, radium-226, radium-228, VOCs, semivolatile compounds, and PCBs. The results are summarized in Table 2.7 for locations J15 and J16. 


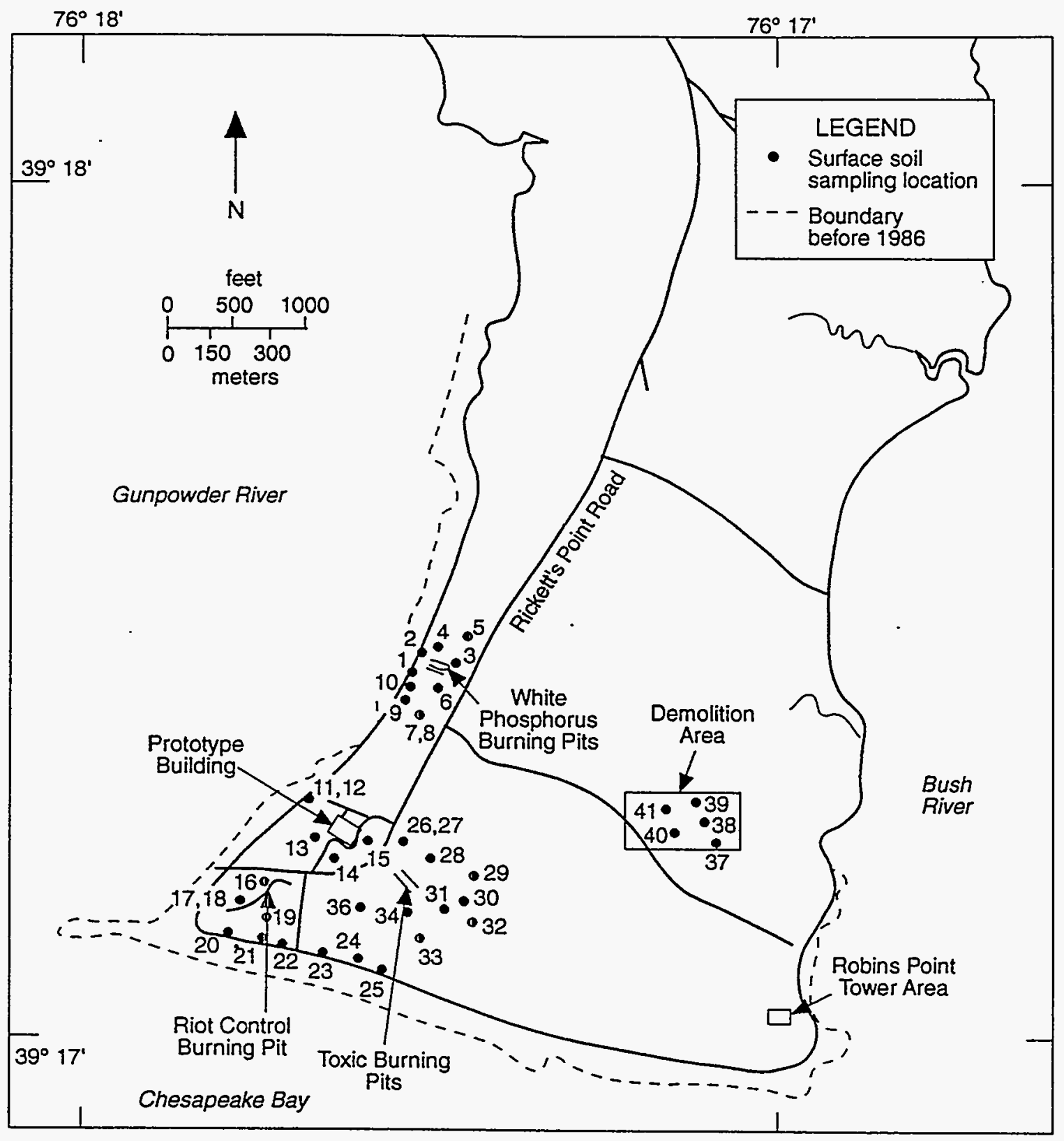

FIGURE 2.9 Locations where Soil Samples Were Collected by the USGS in 1991 (Source: Adapted from Hughes 1992) 
TABLE 2.4 Analytical Results for Analysis of Soil Samples from the Toxic Burning Pits Area, April 1991 ${ }^{\mathrm{a}}$

\begin{tabular}{|c|c|c|c|c|c|c|c|c|c|c|c|c|c|}
\hline \multirow[b]{2}{*}{ Parameter } & \multicolumn{13}{|c|}{ Concentration by Soil Sample Location ${ }^{\text {b }}$} \\
\hline & 23 & 24 & 25 & 26 & 27 & 28 & 29 & 30 & 31 & 32 & 33 & 34 & 36 \\
\hline \multicolumn{14}{|l|}{ Metals (mg/kg) } \\
\hline Arsenic & 3.7 & 3.2 & ND & 4.5 & 4.2 & 7.8 & 49 & 21 & 2.6 & 3.3 & 3.5 & 6.6 & 3.2 \\
\hline Cadmium & ND & ND & ND & ND & ND & 2.4 & 16 & ND & ND & ND & ND & ND & ND \\
\hline Chromium & 14 & 11 & 6.6 & 16 & 15 & 37 & 121 & 46 & 12 & 13 & 13 & 17 & 17 \\
\hline Copper & 21 & 50 & 10 & 22 & 19 & 233 & 786 & 48 & 4.2 & 11 & 15 & 40 & 17 \\
\hline Lead & 17 & 40 & 14 & 41 & 38 & 662 & 87,100 & 952 & 15 & 17 & 29 & 42 & 19 \\
\hline Antimony & ND & ND & ND & ND & ND & ND & 1,120 & ND & ND & $\mathrm{ND}$ & ND & ND & ND \\
\hline Zinc & ND & ND & 20 & 96 & 157 & ND & 7,960 & ND & 25 & ND & ND & ND & ND \\
\hline \multicolumn{14}{|c|}{ Volatile Organic Compounds ( $\mu \mathrm{g} / \mathrm{kg}$ ) } \\
\hline Acetone & 5.89 & 13.9 & 6.73 & 15.8 & 6.75 & 9.80 & 15.7 & 4.88 & 2.24 & ND & 21.0 & ND & ND \\
\hline cis-1,2-Dichloroethylene & NA & NA & NA & NA & NA & 2.4 & NA & 2.40 & NA & NA & NA & NA & NA \\
\hline Trichloroethylene & ND & ND & ND & ND & ND & 1.12 & ND & ND & ND & ND & ND & ND & ND \\
\hline \multicolumn{14}{|c|}{ Semivolatile Organic Compounds ( $\mu \mathrm{g} / \mathrm{kg}$ ) } \\
\hline Butylbenzl phthalate & $\mathrm{ND}$ & 598 & ND & ND & 720 & ND & 580 & ND & ND & ND & ND & ND & ND \\
\hline Benzoic acid & 353 & 7,000 & 1,500 & ND & ND & ND & 420 & 420 & ND & ND & 2,100 & ND & ND \\
\hline \multicolumn{14}{|l|}{ Other (mg/kg) } \\
\hline Total Kjeldahl nitrogen & 1,040 & 2,340 & 695 & 249 & 247 & 637 & 605 & 488 & 627 & 1,030 & 1,730 & 639 & 552 \\
\hline Total organic carbon & 958 & 2,590 & 1,630 & 1,190 & 1,720 & 1,590 & 1,630 & 1,190 & 1,390 & 871 & 1,810 & 752 & 1,010 \\
\hline Total organic halogen & ND & ND & 157 & 20 & 48 & 37 & 34 & ND & ND & ND & ND & ND & ND \\
\hline
\end{tabular}

a $\mathrm{ND}=$ not detected; $\mathrm{NA}=$ not analyzed.

b Locations are shown in Figure 2.9.

Source: Hughes (1992). 


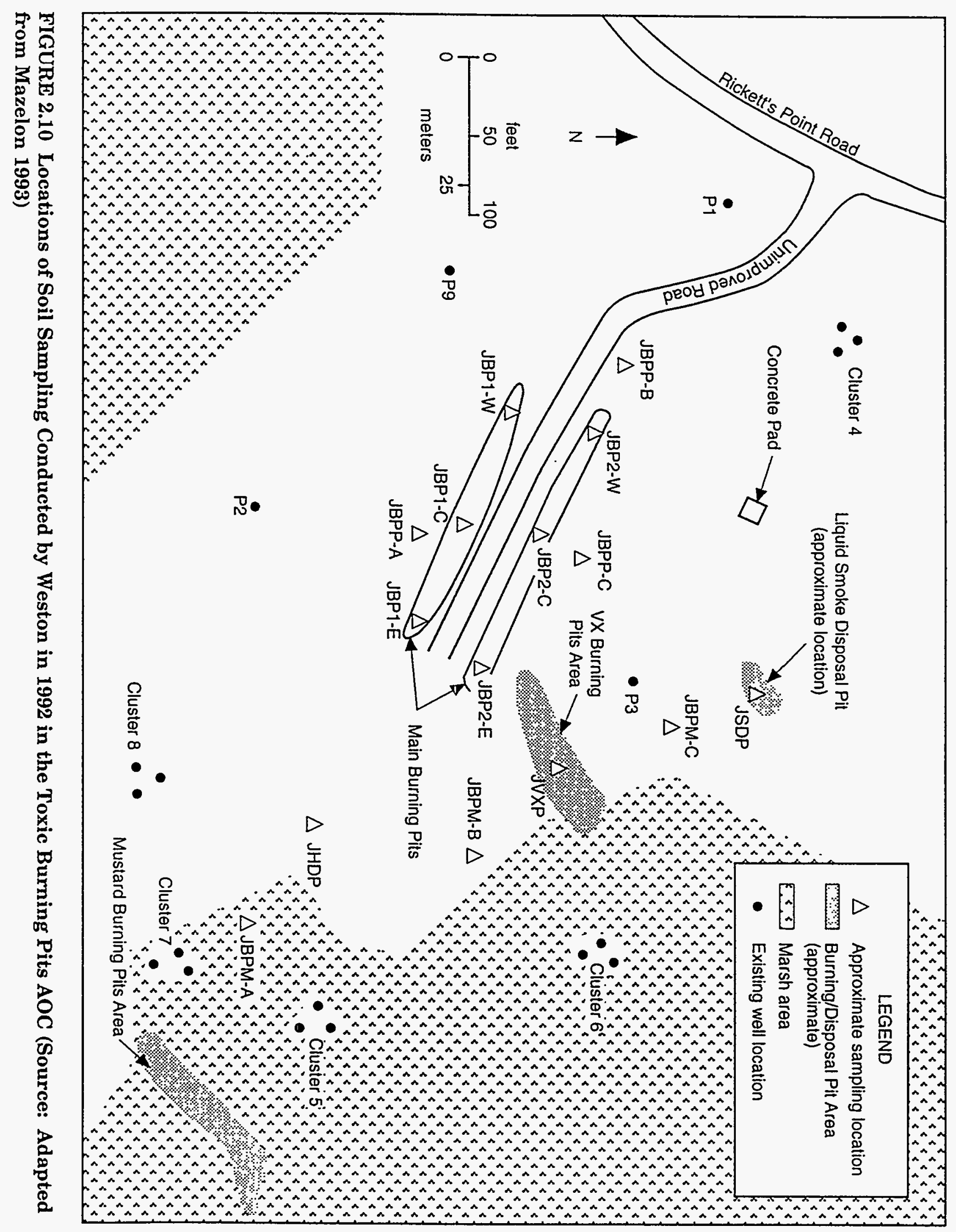


TABLE 2.5 Analytical Results for Target Compound List Analytes in Selected Soil Samples from the Toxic Burning Pits, 1992

\begin{tabular}{|c|c|c|c|c|c|c|c|c|}
\hline \multirow[b]{2}{*}{ TCL $^{b}$ Analyte } & \multicolumn{8}{|c|}{ Concentrations ( $\mu \mathrm{g} / \mathrm{kg}$ ) by Soil Sample Location } \\
\hline & $J B P 1-E\left(2^{\prime}\right)^{c}$ & JBP1-E(4) & JBP2-E(2') & JBP2-E(4) & $\operatorname{JVXP}\left(4^{\circ}\right)$ & $\operatorname{JVXP}\left(6^{\prime}\right)$ & $\operatorname{JSDP}\left(4^{\circ}\right)$ & $\operatorname{JSDP}\left(6^{\prime}\right)$ \\
\hline \multicolumn{9}{|l|}{ Volatile Organic Compounds } \\
\hline 1,1,2,2-Tetrachloroethane & 6.74 & $\mathrm{ND}^{\mathrm{d}}$ & $\mathrm{ND}$ & ND & 167 & 39 & 15,200 & 25.6 \\
\hline 1,1,2-Trichloroethane & ND & ND & ND & ND & ND & ND & 80.5 & ND \\
\hline 1,1-Dichloroethane & ND & ND & ND & ND & ND & ND & ND & ND \\
\hline 1,1-Dichloroethylene & ND & ND & $\mathrm{ND}$ & ND & ND & ND & ND & ND \\
\hline 1,2-Dichloroethane & ND & ND & ND & ND & ND & ND & ND & ND \\
\hline Acetone & 16.4 & 33 & 44.7 & 116 & ND & ND & 344 & ND \\
\hline Benzene & ND & ND & ND & ND & ND & ND & ND & ND \\
\hline Carbon tetrachloride & ND & ND & ND & ND & ND & ND & ND & ND \\
\hline Chloroform & ND & ND & ND & ND & ND & ND & ND & ND \\
\hline Methylene chloride & ND & 6.23 & ND & 6.30 & 7.03 & 8.25 & 44.0 & 12.4 \\
\hline Tetrachloroethylene & ND & ND & ND & ND & ND & ND & ND & ND \\
\hline Toluene & ND & ND & ND & ND & ND & ND & $\mathrm{ND}$ & ND \\
\hline trans-1,2-Dichloroethylene & ND & ND & ND & ND & $\mathrm{ND}$ & $\mathrm{ND}$ & 78.0 & ND \\
\hline Trichloroethylene & 28.1 & ND & ND & ND & ND & 15.8 & 345 & ND \\
\hline Vinyl chloride & ND & ND & ND & ND & ND & ND & ND & ND \\
\hline Xylenes & 12.4 & ND & ND & ND & ND & ND & ND & ND \\
\hline \multicolumn{9}{|c|}{ Semivolatile Organic Compounds } \\
\hline 2-Methylnaphthalene & 471 & ND & ND & ND & ND & ND & ND & ND \\
\hline Hexachloroethane & ND & ND & ND & ND & ND & ND & ND & ND \\
\hline Pyrene & 580 & ND & ND & ND & ND & ND & ND & ND \\
\hline \multicolumn{9}{|l|}{$P C B s$} \\
\hline Aroclor 1248 & 143,000 & 1,180 & ND & ND & ND & ND & ND & ND \\
\hline Aroclor 1254 & ND & ND & 224 & ND & ND & ND & ND & ND \\
\hline
\end{tabular}


TABLE 2.5 (Cont.)

\begin{tabular}{|c|c|c|c|c|c|c|}
\hline \multirow[b]{2}{*}{ TCL Analyte } & \multicolumn{6}{|c|}{ Concentration $(\mu \mathrm{g} / \mathrm{kg})$ by Soil Sample Location } \\
\hline & JHDP(4) & $\mathrm{JHDP}\left(6^{\prime}\right)$ & JBPM-A(3") & JBPM-A(1') & JBPM-B(3") & JBPM-B(1') \\
\hline \multicolumn{7}{|l|}{ Volatile Organic Compounds } \\
\hline 1,1,2,2-Tetrachloroethane & 289,000 & $3,270,000$ & 123 & 1,460 & 13,200 & 15,200 \\
\hline 1,1,2-Trichloroethane & 2,100 & 8,540 & 61.0 & ND & 80.2 & ND \\
\hline 1,1-Dichloroethane & ND & 8.99 & ND & ND & ND & ND \\
\hline 1,1-Dichloroethylene & 31.3 & 77.6 & ND & ND & ND & ND \\
\hline 1,2-Dichloroethane & 40.1 & 62.4 & ND & ND & ND & ND \\
\hline Acetone & 177 & 113 & 275 & ND & 324 & ND \\
\hline Benzene & 19.1 & 83.1 & $\mathrm{ND}$ & ND & ND & ND \\
\hline Carbon tetrachloride & 17.1 & 172 & ND & ND & ND & ND \\
\hline Chloroform & 142 & 445 & ND & $\mathrm{ND}$ & $\mathrm{ND}$ & ND \\
\hline Methylene chloride & 44.9 & 41.2 & 36.1 & ND & 36.2 & ND \\
\hline Tetrachloroethylene & ND & 25,700 & ND & ND & ND & ND \\
\hline Toluene & ND & $\mathrm{ND}$ & $\mathrm{ND}$ & ND & ND & ND \\
\hline trans-1,2-Dichloroethylene & 3,860 & 3,220 & ND & ND & 50.4 & ND \\
\hline Trichloroethylene & 6,780 & 263,000 & 843 & 26,000 & 517 & ND \\
\hline Vinyl chloride & 315 & 302 & $\mathrm{ND}$ & ND & ND & ND \\
\hline Xylenes & ND & ND & ND & ND & ND & ND \\
\hline \multicolumn{7}{|c|}{ Semivolatile Organic Compounds } \\
\hline 2-Methylnaphthalene & ND & ND & ND & ND & ND & ND \\
\hline Hexachloroethane & ND & 628 & ND & 498 & ND & ND \\
\hline Pyrene & ND & ND & ND & ND & ND & ND \\
\hline \multicolumn{7}{|l|}{$P C B s$} \\
\hline Aroclor 1248 & ND & 178 & ND & ND & ND & ND \\
\hline Aroclor 1254 & ND & $\mathrm{ND}$ & 1,700 & 3,160 & ND & ND \\
\hline
\end{tabular}

a Only detected analytes are reported; for samples with duplicate analyses, the higher value is reported.

c Sample depth shown in parentheses.

d $\mathrm{ND}=$ not detected. 
TABLE 2.6 Analytical Results for Target Analyte List Analytes in Selected Soil Samples from the Toxic Burning Pits, 1992 ${ }^{\mathrm{a}}$

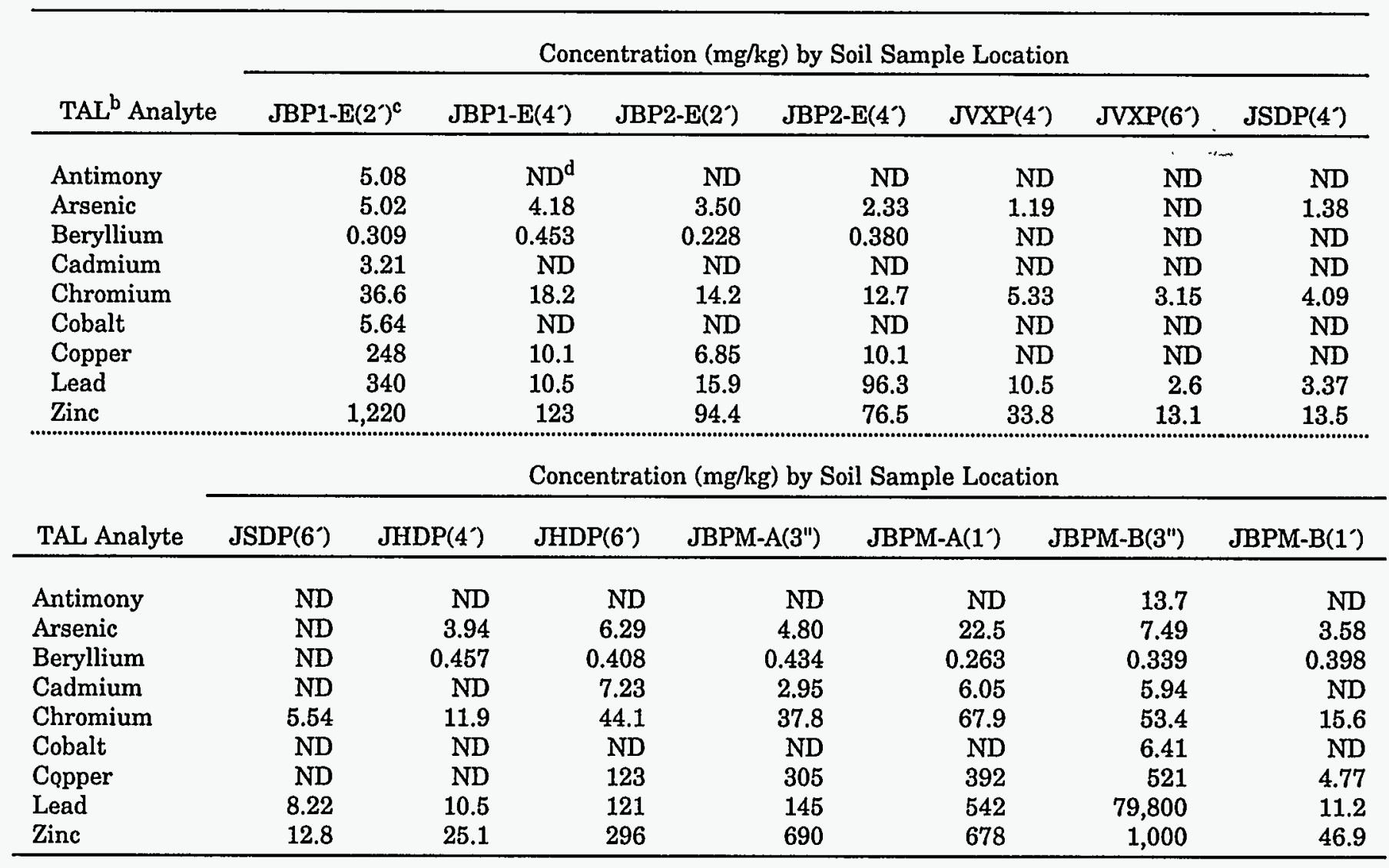

a Only detected analytes are reported; for samples with duplicate analyses, the higher value is reported.

b $\mathrm{TAL}=$ Target Analyte List.

c Sample depth shown in parentheses.

d $\mathrm{ND}=$ not detected.

Source: Mazelon (1993). 
TABLE 2.7 Analytical Results for Surface

Water Samples from the Toxic Burning

Pits Area, 1986

\begin{tabular}{|c|c|c|}
\hline \multirow[b]{2}{*}{ Parameter $^{\mathbf{a}}$} & \multicolumn{2}{|c|}{ Location } \\
\hline & J15 & J16 \\
\hline \multicolumn{3}{|l|}{ Dissolved Metals ( $\mu g / L)$} \\
\hline Cadmium & $<1.0$ & 2.0 \\
\hline Lead & 40 & 104 \\
\hline Mercury & 0.60 & $<0.20$ \\
\hline \multicolumn{2}{|c|}{ Inorganic Compounds $(\mu g / L)$} & $\cdot$ \\
\hline Nitrate and nitrite as $N$ & $<30$ & 60 \\
\hline Sulfate & 12,000 & 16,000 \\
\hline Chloride & 3,000 & 4,000 \\
\hline Total dissolved solids & $\mathrm{NA}^{\mathrm{b}}$ & 34,000 \\
\hline \multicolumn{3}{|l|}{ Radioactivity (pCi/L) } \\
\hline Gross alpha & $<0.8$ & 7.0 \\
\hline Gross beta & 5.7 & 15 \\
\hline Radium-226 & NA & 0.50 \\
\hline Radium-228 & $\mathrm{NA}$ & 1.4 \\
\hline
\end{tabular}

a Includes parameters that were detected in one or more samples. No detection limits given for VOCs, semivolatile compounds, and PCBs.

b $\mathrm{NA}=$ Not analyzed.

Source: Nemeth (1989).

The surface water contained some lead contamination. The lead concentration at location 16 was above the primary drinking water standard $(50 \mu \mathrm{g} / \mathrm{L})$. The gross alpha radionuclide was also slightly elevated at location 16 . The radioactivity measurements were consistent with results from a field radiation survey of the TBP for materials emitting beta and gamma radioactivity. No radiation above background levels was detected (Nemeth 1989).

The USGS collected nearshore surface water samples from the Gunpowder River (9 locations) and the Chesapeake Bay (11 locations) at low tide. One sample was collected onshore in a drainage ditch. Sampling locations are shown in Figure 2.11. Filtered and unfiltered samples were analyzed for water quality parameters, metals, and a few organic compounds. Nitrate concentrations in samples from locations 3, 7, and 13 ranged from 280 to $400 \mu \mathrm{g} / \mathrm{L}$. The metals data showed the presence of lead (from not detected [ND] ${ }^{1}$ to

1 The detection limits for analyses were not reported. 
(I66I SDSn moxy pəzdepF :əoxnos) 886I แ! pIอ!.

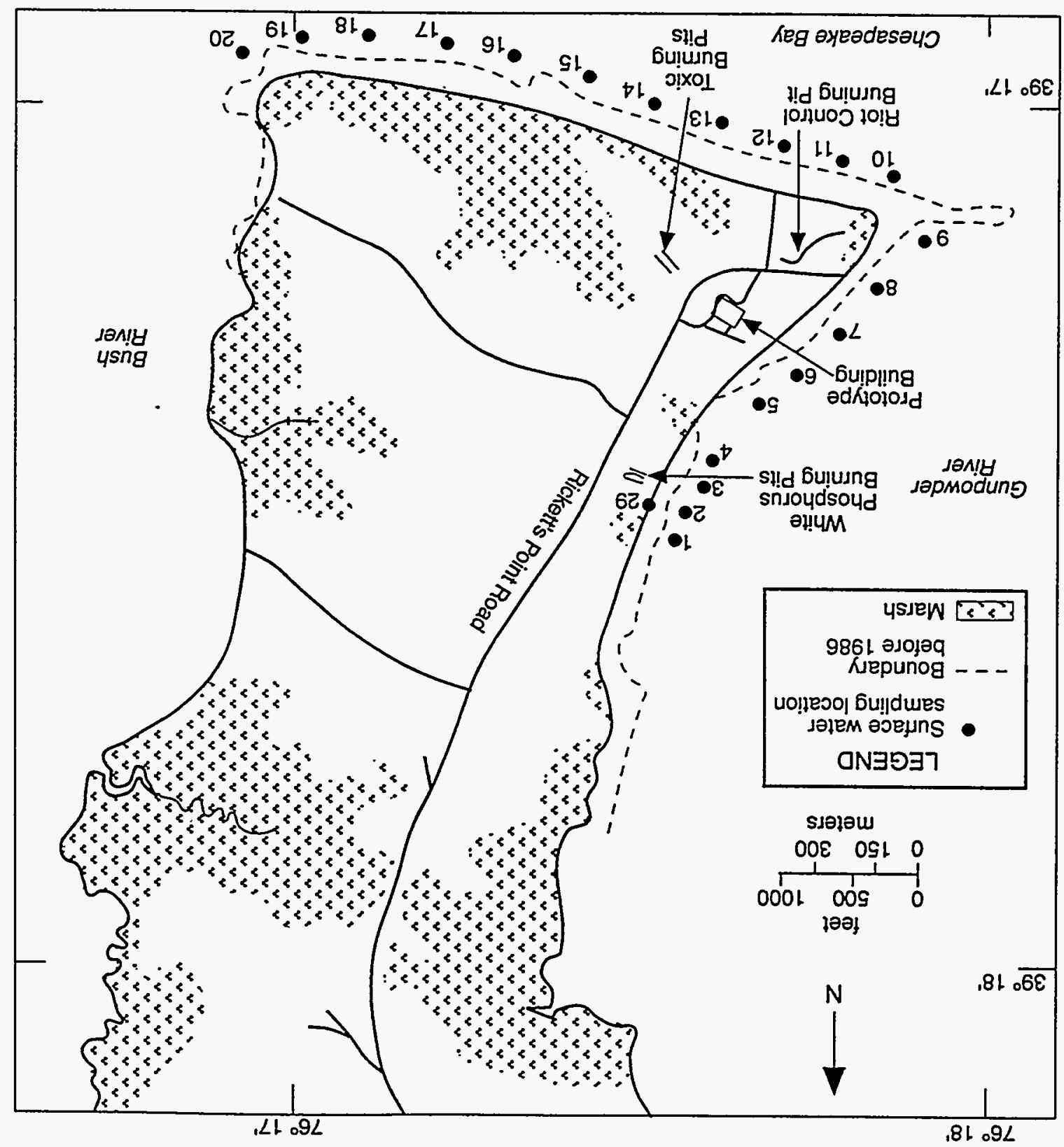


$28 \mu \mathrm{g} / \mathrm{L})$ and zinc $(50-133 \mu \mathrm{g} / \mathrm{L})$ at locations 1 through 4 . Lead and zinc concentrations at the other locations ranged from ND to 2.68 and $48 \mu \mathrm{g} / \mathrm{L}$, respectively. Mercury and nickel concentrations were slightly elevated at location $1(0.54$ and $33.7 \mu \mathrm{g} / \mathrm{L}$, respectively). No evidence was found of elevated concentrations of arsenic, barium, or chromium. Comparison of results from filtered and unfiltered samples showed that the elevated metals concentrations may be associated with the suspended solids in the samples (Hughes 1993).

Acetone, toluene, phenol, total organic carbon (TOC), and total organic halogen (TOX) were analyzed in the filtered and unfiltered samples from nine locations. Phenol (ND to $51.9 \mu \mathrm{g} / \mathrm{L})$, TOC $(4,000-7,000 \mu \mathrm{g} / \mathrm{L})$, and TOX $(21.6-30.4 \mu \mathrm{g} / \mathrm{L})$ were detected in the unfiltered samples only. The presence of acetone in some of the samples may represent laboratory contamination. Toluene $(3.05 \mu \mathrm{g} / \mathrm{L}$ ) was found at location 1 (Hughes 1993).

The data for the nearshore surface water have shown essentially no contamination. Contaminants appear to be associated with the suspended solids, suggesting that the nearshore sediments may be contaminated.

In August 1992, the EPA emergency response team (ERT) collected nearshore surface water and sediment samples at 17 locations around the peninsula - in the Gunpowder and Bush rivers and in Chesapeake Bay (Figure 2.12). Filtered surface water samples were analyzed for VOCs, base neutral and acid extractable organic compounds (BNA), Target Analyte List (TAL) metals, pesticides, PCBs, and inorganic parameters (sulfate, total Kjeldahl nitrogen [TKN], total phosphorus, and cyanide). The data showed that beryllium, lead, and mercury were below their respective detection limits of $6,000,6,000$, and $200 \mu \mathrm{gg} / \mathrm{L}$. Zinc concentrations ranged from $11,000 \mu \mathrm{g} / \mathrm{L}$ at locations 3,4 , and 16 to $96,000 \mu \mathrm{g} / \mathrm{L}$ at location 6 . Nickel concentrations ranged from $28,000 \mu \mathrm{g} / \mathrm{L}$ at most locations to $38,000 \mu \mathrm{g} / \mathrm{L}$ at location 9 . No cyanide, VOCs, pesticides, or PCBs were detected.

Sediment samples, collected at the same locations as the surface water, were analyzed for CWAs and CWA degradation products, explosives, VOCs, BNA, TAL metals, pesticides, PCBs, and other parameters (TOC, sulfate, total phosphorus, TKN, and percent solids). The results indicate that there is essentially no contamination in sediments at these locations, although lead was detected at concentrations ranging from $2 \mathrm{mg} / \mathrm{L}$ at location 11 to $22 \mathrm{mg} / \mathrm{L}$ at location 17. Arsenic and cadmium were also detected: arsenic at concentrations ranging from 1 to $6 \mathrm{mg} / \mathrm{L}$ (at location 6) and cadmium at concentrations ranging from $<0.5$ to $3 \mathrm{mg} / \mathrm{L}$ (at location 8 ). The detection limit for beryllium was fairly high, ranging from 0.5 to $2.6 \mathrm{mg} / \mathrm{L}$. The only VOC detected was acetone, up to $101 \mu \mathrm{g} / \mathrm{kg}$ at location 7.

\section{Groundwater}

Eleven groundwater monitoring wells (TH series) were installed in J-Field during the 1977 environmental survey. Locations of these wells are shown in Figure 2.13. Only one well (TH4) was installed in the area of the TBP. Well depths ranged from 20 to $25 \mathrm{ft}$. The 


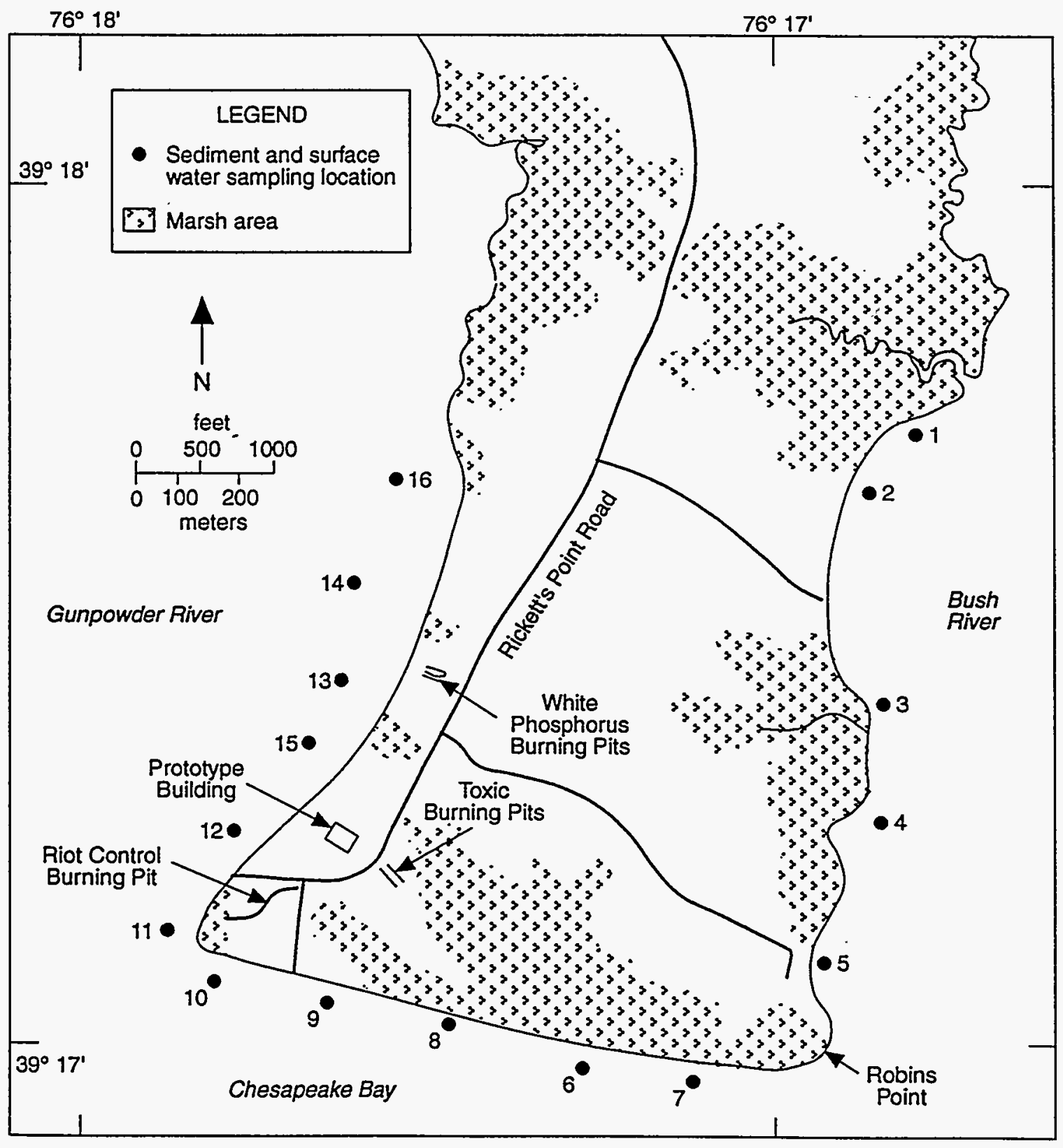

FIGURE 2.12 Locations of Surface Water and Sediment Samples Collected at J-Field in 1992 (Source: EPA 1992a) 


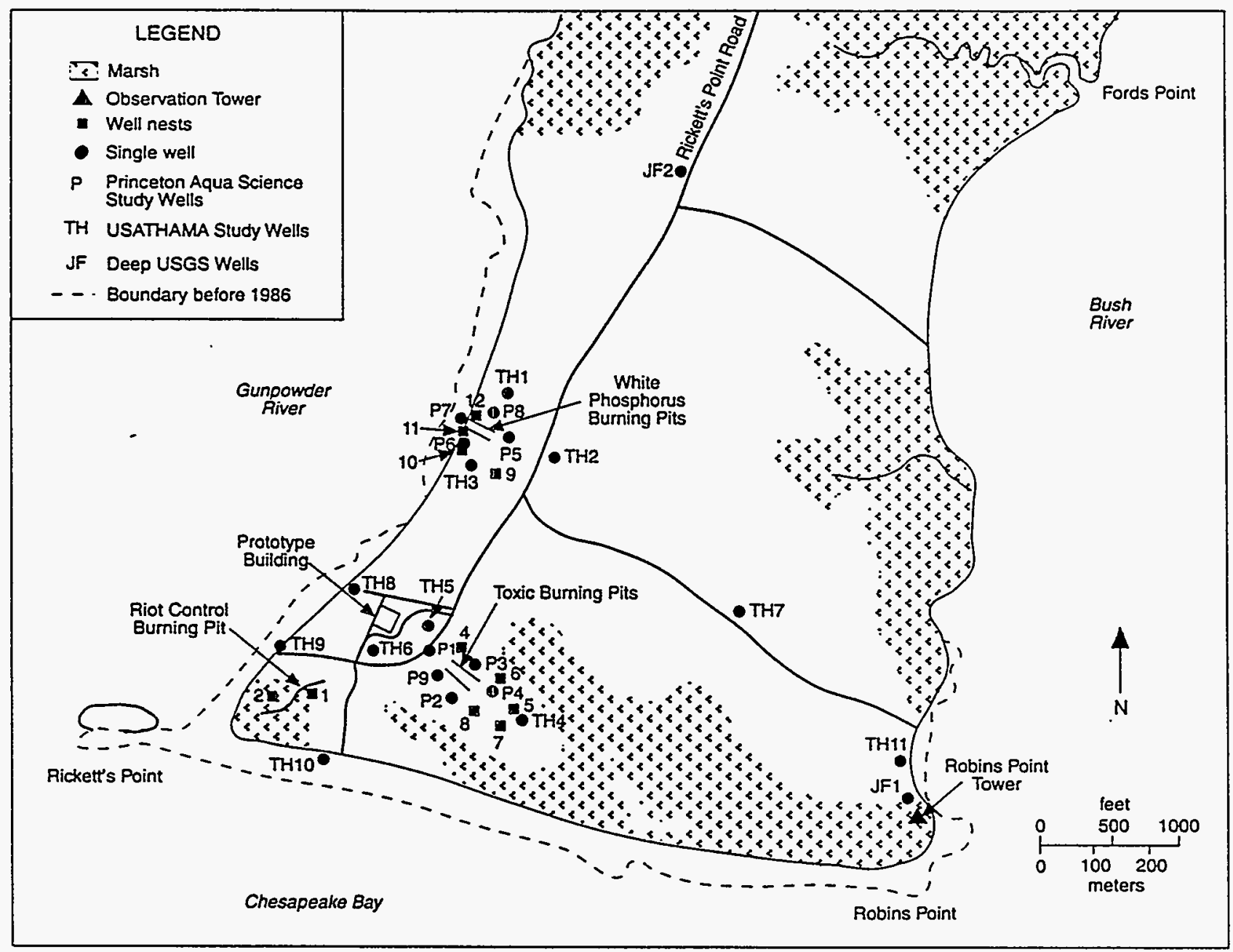

FIGURE 2.13 Locations of All Wells Installed at J-Field (Source: Adapted from Hughes 1993)

wells were screened in the surficial aquifer with 25-ft-long screens (Sonntag 1991). Samples collected from the wells in 1977 were analyzed for metals, inorganic chemicals, white phosphorus, mustard degradation products, cholinesterase inhibitors, semivolatile compounds, and VOCs. Organic contaminants (up to $200,000 \mu \mathrm{g} / \mathrm{L}$ ) were found in all of the wells (no data were given for TH7).

Five additional wells were installed around the TBP as part of a munitions disposal study (Figure 2.13, P series) (Princeton Aqua Science 1984). The wells were screened in the surficial aquifer from depths of $17-20 \mathrm{ft}$ with 15-ft-long screens (Sonntag 1991). Water samples collected from the wells in 1983 were analyzed for metals, nitrate, TOX, TOC, radioactivity, pesticides, herbicides, and secondary drinking water parameters. Two of the five wells (P4 and P5) contained elevated concentrations of the gross beta radionuclide (140 and $12 \mathrm{pCi} / \mathrm{L}$, respectively). Two wells (P3 and $\mathrm{P} 4)$ contained TOX (6.6 and $7.1 \mathrm{mg} / \mathrm{L}$, respectively). Two wells (P2 and P5) contained elevated concentrations of nitrates (12 and $10 \mathrm{mg} / \mathrm{L}$, respectively). . 
The P-series wells were sampled again in 1986 as part of the Edgewood Area RFA (Nemeth 1989). The samples were analyzed for metals, explosives-related compounds, inorganic compounds, radioactivity, thiodiglycol, VOCs, semivolatile compounds, and PCBs. The results are summarized in Table 2.8. Elevated concentrations of VOCs were found in only two wells (P3 and P4), near the area exhibiting soil-gas contamination. The compounds found include trans-1,2-dichloroethylene (trans-12DCE), up to 8,500 $\mu / \mathrm{L}$ in well P4; TRCLE, up to $6,700 \mu \mathrm{g} / \mathrm{L}$ in well P4; vinyl chloride, up to $550 \mu \mathrm{g} / \mathrm{L}$ in well P3; and TCLEE, up to $420 \mu \mathrm{g} / \mathrm{L}$ in well P3. The data also indicate that the elevated gross beta activity detected in well P3 was due to naturally occurring potassium-40; however, it is not clear why potassium concentrations were so much higher in this well than in the others.

Thirty-eight additional monitoring wells were installed by the USGS in 1988 and 1989 (Sonntag 1991; Hughes 1993). Two of these wells, JF1 and JF2, were installed and screened in the Potomac Group. The 36 other wells were placed in nests of 3 at 12 different locations (Figure 2.13). Well nests JF3-JF8 were placed in the TBP area. The nested wells were screened in the confined aquifer, the leaky confining unit, and the surficial aquifer. The naming convention for the well nests involves a combination of letters and numbers. The letters with numbers (i.e., JF1-JF12) indicate the location. This location indicator code is then coupled with the numbers 1, 2, or 3 to indicate the strata being monitored. The confined aquifer is designated by the number 1 , the leaky confining unit by the number 2 , and the surficial aquifer by the number 3 .

During 1990, samples from 55 of the 58 existing wells at J-Field were analyzed for metals, inorganic compounds, VOCs, and semivolatile organic compounds. Several of the wells were also analyzed for organosulfur, explosives, and radioactive contaminants. Wells were selected for specific contaminant analyses on the basis of the nature of disposal activities that had occurred nearby (USGS 1991).

Table 2.9 summarizes the analytical results indicating the presence of metals and other inorganic compounds. Concentrations of lead $(124 \mu \mathrm{g} / \mathrm{L})$ in well P9 and arsenic $(60 \mu \mathrm{g} / \mathrm{L})$ in well JF83 exceed maximum contaminant levels (MCLs). Both of these wells are downgradient from the TBP. Potassium concentrations ranged from not detected to $140 \mu \mathrm{g} / \mathrm{L}$. Except for one measurement at well P3, the elevated concentrations of potassium (above $50 \mu \mathrm{g} / \mathrm{L}$ ) occurred in the leaky confining unit or the confined aquifer. Movement of sea water into the groundwater may not be a source of potassium because wells with elevated potassium do not have elevated chloride concentrations.

The analytical results (summarized in Table 2.10) show that the TBP are contaminated with VOCs, and a contaminant plume in the groundwater extends downgradient to the southeast. This condition is reflected in the elevated concentrations of 112TCE, 1,2-dichloroethylene (12DCE), TCLEA, TCLEE, and TRCLE in well nests JF5, JF7, and JF8. The concentrations are highest in the surficial aquifer - up to $7,150 \mu \mathrm{g} / \mathrm{L} 12 \mathrm{DCE}$ in wells JF73 and JF83. The data also show that some contamination extends down into the leaky confining unit and the confined aquifer (1,400 $\mu \mathrm{g} / \mathrm{L}$ TRCLE in the leaky confining unit [JF82] 
TABLE 2.8 Analytical Results for Groundwater from the P-Series Monitoring Wells, 1986

\begin{tabular}{|c|c|c|c|c|c|}
\hline \multirow[b]{2}{*}{ Parameter $^{2}$} & \multicolumn{5}{|c|}{ Concentration by Well } \\
\hline & $\mathrm{P} 1$ & P2 & P3 & $\mathrm{P} 4$ & P9 \\
\hline \multicolumn{6}{|c|}{ Dissolved Metals ( $\mu \mathrm{g} / L)$} \\
\hline Arsenic & $<10$ & $<10$ & 24 & $<10$ & $<10$ \\
\hline Cadmium & $<1$ & $<1$ & $<1$ & 3 & $<1$ \\
\hline Lead & $<5$ & $<5$ & $<5$ & 90 & $<5$ \\
\hline Selenium & $<5$ & 9 & 54 & 26 & $<5$ \\
\hline Potassium & 1,040 & 733 & 113,000 & 1,380 & 782 \\
\hline \multicolumn{6}{|c|}{ Inorganic Compounds ( $\mu \mathrm{g} / \mathrm{L})$} \\
\hline Nitrate/nitrite as $\mathrm{N}$ & 490 & 12,000 & $<50$ & $<50$ & 8,000 \\
\hline Sulfate & 54,000 & 105,000 & 362,000 & 93,000 & 94,000 \\
\hline Chloride & 4,800 & 23,000 & 304,000 & 866,000 & 24,000 \\
\hline Total phosphate as $\mathrm{P}$ & $N A^{b}$ & NA & NA & NA & NA \\
\hline Total dissolved solids & 125,000 & 328,000 & $1,403,000$ & $1,087,000$ & 262,000 \\
\hline \multicolumn{6}{|l|}{ Radioactivity (pCi/L) } \\
\hline Gross beta & 1.3 & 2.5 & 100 & $<4.8$ & 1.4 \\
\hline Potassium -40 & $\mathrm{NA}$ & NA & 120 & NA & NA \\
\hline Radium-226 & NA & NA & 0.43 & NA & NA \\
\hline \multicolumn{6}{|c|}{ Volatile Organic Compounds ( $\mu g / L)$} \\
\hline Benzene & $\mathrm{ND}^{\mathrm{c}}$ & ND & 6.0 & ND & ND \\
\hline Chlorobenzene & $\mathrm{ND}$ & ND & 980 & ND & ND \\
\hline Ethyl benzene & ND & ND & 3.0 & ND & ND \\
\hline Toluene & ND & ND & 5.0 & ND & ND \\
\hline Chloroform & ND & ND & 7.0 & 3.0 & ND \\
\hline Carbon tetrachloride & ND & 5.0 & ND & ND & ND \\
\hline $112 \mathrm{TCE}$ & ND & ND & 7.0 & 130 & ND \\
\hline TCLEA & ND & ND & ND & 200 & 5.0 \\
\hline Vinyl chloride & ND & ND & 550 & 48 & ND \\
\hline trans-12DCE & ND & ND & 2,220 & 8,500 & ND \\
\hline TRCLE & ND & ND & 980 & 6,700 & 5.0 \\
\hline TCLEE & ND & ND & 420 & ND & $\mathrm{ND}$ \\
\hline
\end{tabular}

a Includes all parameters that were detected at least once. Metals analyzed but not detected: barium $(<300 \mu \mathrm{g} / \mathrm{L})$, chromium $(<10 \mu \mathrm{g} / \mathrm{L})$, mercury $(<0.2 \mu \mathrm{g} / \mathrm{L})$, and silver $(<25 \mu \mathrm{g} / \mathrm{L})$.

b $\mathrm{NA}=$ not analyzed.

c $\mathrm{ND}=$ not detected.

Source: Nemeth (1989). 
'TABLE 2.9 Analytical Results for Selected Inorganic Compounds, TOC, and Metals in Groundwater from the Toxic Burning Pits, 1990

\begin{tabular}{|c|c|c|c|c|c|c|c|c|c|}
\hline Well & $\begin{array}{c}\text { Chloride } \\
(\mathrm{mg} / \mathrm{L})\end{array}$ & $\begin{array}{c}\text { Potassium } \\
(\mathrm{mg} / \mathrm{L})\end{array}$ & $\begin{array}{c}\text { TOC } \\
(\mathrm{mg} / \mathrm{L})\end{array}$ & $\begin{array}{c}\text { Arsenic } \\
(\mu \mathrm{g} / \mathrm{L})\end{array}$ & $\begin{array}{c}\text { Cyanide } \\
(\mu \mathrm{g} / \mathrm{L})\end{array}$ & $\begin{array}{c}\text { Lead } \\
(\mu \mathrm{g} / \mathrm{L})\end{array}$ & $\begin{array}{l}\text { Nickel } \\
(\mu \mathrm{g} / \mathrm{L})\end{array}$ & $\begin{array}{c}\text { Selenium } \\
(\mu \mathrm{g} / \mathrm{L})\end{array}$ & $\begin{array}{c}\text { Zinc } \\
(\mu \mathrm{g} / \mathrm{L})\end{array}$ \\
\hline P2 & $<100$ & $<50$ & $<10$ & $\mathrm{ND}^{\mathrm{a}}$ & ND & ND & $\mathrm{ND}$ & 3.8 & ND \\
\hline P3 & $<100$ & 61.8 & 25 & 30.2 & ND & ND & 61.9 & ND & ND \\
\hline $\mathrm{P} 4$ & 390 & $<50$ & $<10$ & ND & ND & ND & ND & ND & 292 \\
\hline P9 & $<100$ & $<50$ & $<10$ & ND & ND & 124 & ND & ND & ND \\
\hline TH4 & $<100$ & $<50$ & $<10$ & $\mathrm{ND}$ & $\mathrm{ND}$ & $\mathrm{ND}$ & ND & 2.35 & ND \\
\hline JF51 & $<100$ & 140 & $<10$ & ND & 13.9 & ND & $\mathrm{ND}$ & ND & ND \\
\hline JF52 & $<100$ & $<50$ & $<10$ & ND & ND & ND & ND & ND & ND \\
\hline JF53 & $<100$ & $<50$ & $<10$ & ND & ND & ND & 440 & ND & ND \\
\hline JF61 & $<100$ & 98 & 160 & 8.03 & ND & ND & ND & ND & ND \\
\hline JF62 & $<100$ & $<50$ & 10 & $\mathrm{ND}$ & ND & ND & ND & ND & ND \\
\hline JF63 & 180 & $<50$ & 50 & 4.11 & ND & ND & ND & ND & ND \\
\hline JF71 & $<100$ & 79 & $<10$ & 3.32 & ND & ND & ND & ND & ND \\
\hline JF72 & $<100$ & $<50$ & 180 & ND & ND & ND & ND & 3.21 & ND \\
\hline JF73 & $<100$ & $<50$ & $<10$ & 5.52 & ND & ND & ND & ND & ND \\
\hline JF81 & 130 & $<50$ & $<10$ & $\mathrm{ND}$ & ND & ND & ND & ND & ND \\
\hline JF82 & $<100$ & 74.7 & 100 & 20.4 & 88 & ND & ND & ND & ND \\
\hline JF83 & 120 & $<50$ & $<10$ & 60 & ND & ND & ND & 6.18 & ND \\
\hline
\end{tabular}

a $\mathrm{ND}=$ not detected.

Source: USGS (1991). 
TABLE 2.10 Analytical Results for Selected VOCs in Groundwater from the Toxic Burning Pits Area, 1990

\begin{tabular}{|c|c|c|c|c|c|c|c|c|c|}
\hline \multirow[b]{2}{*}{ Well $^{\mathrm{a}}$} & \multicolumn{9}{|c|}{ VOC $^{b}$ Concentrations $(\mu g / L)$} \\
\hline & 112TCE & 11DCE & 12DCE & $\mathrm{C} 2 \mathrm{H} 3 \mathrm{CL}$ & $\mathrm{C} 6 \mathrm{H} 6$ & CHCL3 & TCLEA & TCLEE & TRCLE \\
\hline P2 & 4.02 & $\mathrm{ND}^{\mathrm{c}}$ & 10.2 & ND & ND & $\mathrm{ND}$ & 101 & ND & 440 \\
\hline TH4 & ND & $\mathrm{ND}$ & $\mathrm{ND}$ & ND & $\mathrm{ND}$ & ND & 3.73 & ND & ND \\
\hline JF53 & 110 & 8.04 & 850 & 132 & ND & ND & 3,500 & $\mathrm{ND}$ & 820 \\
\hline JF52 & 10 & ND & 420 & ND & $\mathrm{ND}$ & 2.2 & 34.3 & ND & 52 \\
\hline JF51 & ND & 3.79 & 430 & ND & ND & ND & ND & $\mathrm{ND}$ & 520 \\
\hline JF63 & ND & ND & 7.33 & ND & $\mathrm{ND}$ & 7.6 & ND & 17.6 & 600 \\
\hline JF62 & ND & ND & $\mathrm{ND}$ & ND & $\mathrm{ND}$ & ND & $\mathrm{ND}$ & ND & 2.7 \\
\hline JF61 & $\mathrm{ND}$ & $\mathrm{ND}$ & ND & ND & ND & ND & $\mathrm{ND}$ & $\mathrm{ND}$ & 1.8 \\
\hline JF73 & 67.3 & 6.81 & 7,150 & ND & $\mathrm{ND}$ & 2.9 & 340 & ND & 1,800 \\
\hline JF72 & $\mathrm{ND}$ & ND & 32.6 & ND & ND & 1.9 & $\mathrm{ND}$ & $\mathrm{ND}$ & 4.5 \\
\hline JF71 & ND & ND & ND & $\mathrm{ND}$ & ND & 24 & $\mathrm{ND}$ & ND & 7.3 \\
\hline JF83 & 7,100 & 19 & 7,150 & 56.3 & 4.88 & 50 & 250 & 1,000 & 4,900 \\
\hline JF82 & $\mathrm{ND}$ & 30.1 & 210 & $\mathrm{ND}$ & ND & 5.6 & $\mathrm{ND}$ & 47.2 & 1,400 \\
\hline JF81 & 7,100 & ND & 34.6 & ND & ND & ND & 290 & $\mathrm{ND}$ & 230 \\
\hline
\end{tabular}

a TBP wells not listed contained no VOCs, or traces of 111TCE, C2H5CL, CCL4, CH3CL, and C6H5CL. No data for wells P1, P3, P4, JF43, JF41.

b Installation Restoration Data Management System (IRDMS) acronyms are used for VOCs: 112TCE = 1,1,2-trichloroethane; 11DCE = 1,1-dichloroethylene; $12 \mathrm{DCE}=1$-2-dichloroethylene; $\mathrm{C} 2 \mathrm{H} 3 \mathrm{CL}=$ vinyl chloride; C6H6 = benzene; CHCL3 = chloroform; TCLEA = 1,1,2,2-tetrachloroethane; TCLEE = tetrachloroethylene; and TRCLE = trichloroethylene.

c $\mathrm{ND}=$ not detected.

Source: USGS (1991). 
and $7,100 \mu \mathrm{g} / \mathrm{L} 112 \mathrm{TCE}$ in the confined aquifer [JF81]). Bec the confined aquifer are at depths of $70 \mathrm{ft}$ or more (well $120-123 \mathrm{ft}$ ), VOC contamination extends more than $100 \mathrm{ft}$,
Ise the well screens monitoring F81 is screened at a depth of ep.

Because TRCLE was detected most often, the TRI JE data were used to create a contour map of contamination in the surficial aquifer (Figure 3.14). Those contours show that a plume of contaminated groundwater extends south of $t$ e TBP area to the shore and, possibly, into the bay. Additional data on VOC concent ations in the groundwater at locations farther south and closer to the shore are needed $i$, determine if the plume in the surficial aquifer extends into the bay.

Data for the single wells screened in the Potomac indicate low concentrations of VOC contamination in the de $2.25 \mu \mathrm{g} / \mathrm{L}$ 1,1,1-trichloroethane (111TCE) at a depth of 185-1! roup sediments (JF1 and JF2) ser strata. Well JF1 contained $\mathrm{ft}$; well JF2 contained $6.7 \mu \mathrm{g} / \mathrm{L}$

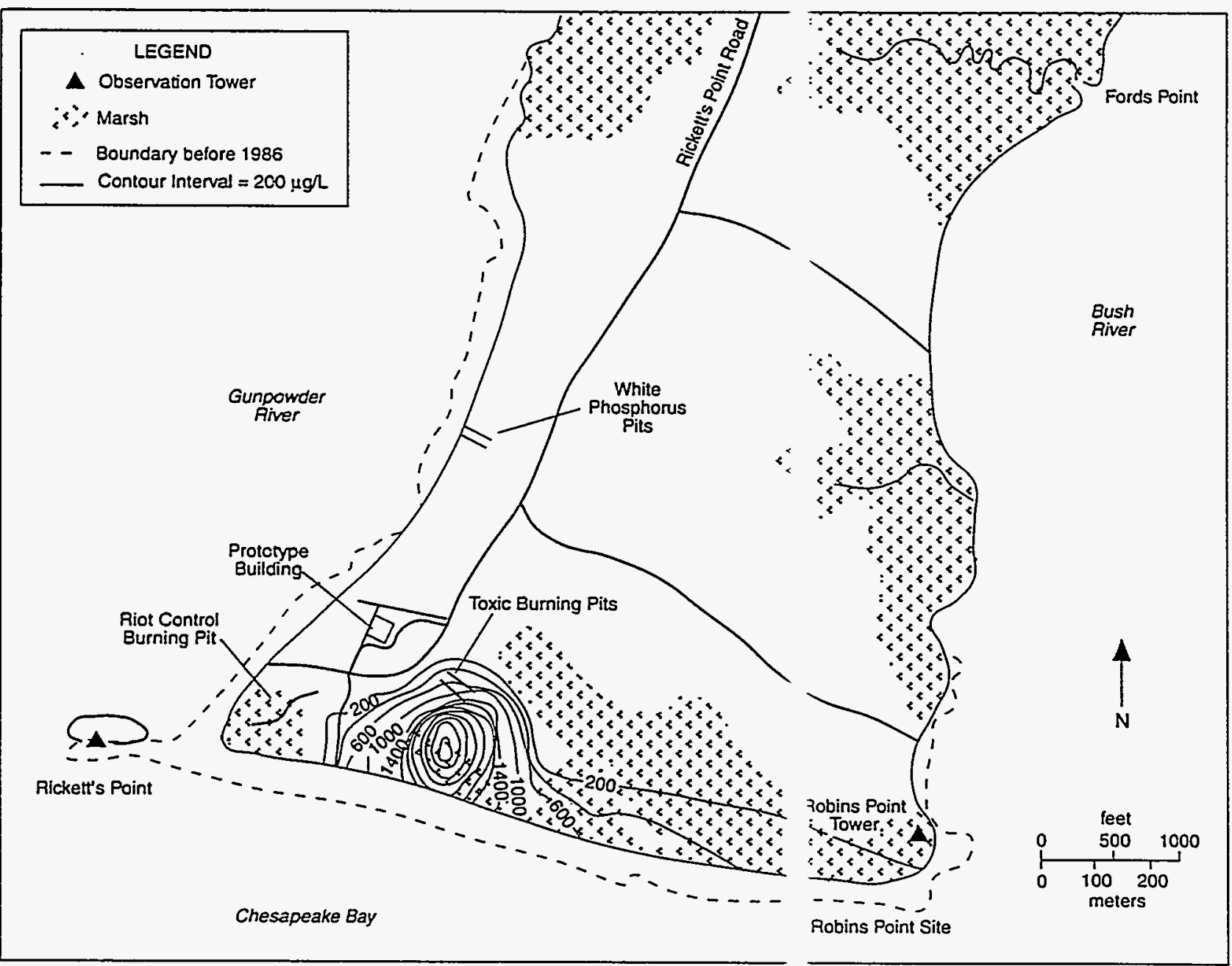

FIGURE 2.14 Contours of TRCLE Concentrations $(\mu \mathrm{g} / \mathrm{L}) \mathrm{i}$ : the Surficial Aquifer (contour interval $=200 \mu \mathrm{g} / \mathrm{L}$ ) (Source: Adapted from Hugl 's 1993) 
TRCLE at 208-213 ft. These values are questionable because one of the two blanks associated with the sampling event contained detectable concentrations of TCLEA, TCLEE, and TRCLE.

Groundwater samples from a few wells were analyzed for explosives and organosulfur compounds. Results are summarized in Table 2.11. The data indicate some contamination with organosulfur compounds (including degradation products of mustard) in the surficial aquifer downgradient from the TBP. The maximum concentration was $140 \mu \mathrm{g} / \mathrm{L}$ 1,4-dithiane in well P3 just north of the western end of the TBP. No organosulfur contamination was found in the middle or lower aquifers. Explosives-related compounds were also found in low concentrations (up to $226 \mu \mathrm{g} / \mathrm{L}$ nitrocellulose) in the water table and the lower aquifer. Because nitrocellulose is not soluble in water, this value is either lab error or due to suspended solids in the groundwater sample.

TABLE 2.11 Analytical Results for Organosulfur and Explosives-Related Compounds in Groundwater from the Toxic Burning Pits Area, 1990

\begin{tabular}{|c|c|c|c|c|c|}
\hline \multirow[b]{2}{*}{ Well } & \multicolumn{5}{|c|}{ Concentrations of Organosulfur Compounds $(\mu \mathrm{g} / \mathrm{L})$} \\
\hline & $\begin{array}{l}\text { 4-Chlorophenyl- } \\
\text { methsulfoxide }\end{array}$ & $\begin{array}{l}\text { 4-Chlorophenyl- } \\
\text { sulfone }\end{array}$ & 1,4-Dithiane & 1,4-Oxithiane & Thiodiglycol \\
\hline P3 & $\mathrm{ND}^{\mathrm{a}}$ & ND & 140 & ND & $\mathrm{NA}^{\mathrm{b}}$ \\
\hline $\mathrm{P} 4$ & ND & ND & 8.28 & ND & NA \\
\hline JF53 & ND & ND & 2.11 & ND & $\mathrm{ND}$ \\
\hline JF63 & ND & $\mathrm{ND}$ & 8.21 & 8.24 & 21 \\
\hline JF83 & ND & 20.5 & ND & ND & NA \\
\hline
\end{tabular}

Concentrations of Explosives-Related Compounds ( $\mathrm{\mu g} / \mathrm{L}$ )

\begin{tabular}{llcccc} 
& & Nitro- & Nitro- & & \\
& DNT $^{\mathrm{c}}$ & benzene & cellulose & PETN $^{\mathrm{d}}$ & RDX $^{\mathrm{e}}$ \\
\cline { 2 - 6 } P9 & ND & ND & 226 & ND & 0.496 \\
JF43 & ND & ND & 21.3 & ND & ND \\
JF51 & ND & ND.0889 & ND & ND & ND \\
JF63 & ND & ND & ND & 15.9 & ND \\
JF73 & ND & ND & ND & ND & 1.18 \\
\hline
\end{tabular}

a $\mathrm{ND}=$ not detected.

b $\mathrm{NA}=$ no data available.

c $\mathrm{DNT}=$ dinitrotoluene.

d PETN = penta-erythritol tetranitrate.

e $\mathrm{RDX}=$ hexahydro-1,3,5-trinitro-1,3,4-triazine.

Source: USGS (1991). 
Concentrations of the radioactive species uranium, thorium-230, cesium-137, and strontium-90 were measured in monitoring wells P1, P3, P4, JF53, JF52, JF51, JF63, and JF73. Elevated concentrations of cesium-137 (up to $172 \mathrm{pCi} / \mathrm{L}$ ) and strontium-90 (up to $128 \mathrm{pCi} / \mathrm{L}$ ), measured as beta radiation, were found in wells P3, JF51, and JF73 (USGS 1991). If these values are confirmed by additional measurements, they would indicate the presence of radioactive contaminants.

In 1992, the USGS analyzed groundwater collected from wells in the TBP area (Figure 2.13) for VOCs (Table 2.12). The data indicate that VOCs are present in the three aquifers underlying $J$-Field (surficial unit, confining unit, and confined unit); that concentrations of TRCLE, TCLEE, TCLEA, chloroform (CHCL3), 12DCE, and 112TCE have increased significantly since 1990 (see also Table 2.10); and that concentrations of 1,1-dichloroethylene (11DCE) have not been detected.

The highest VOC concentrations were found in well clusters JF5, 6, 7, and 8 in all three aquifers. The greatest increases in concentrations were found in JF83, which monitors

TABLE 2.12 Analytical Results for Selected VOCs in Groundwater Samples from the Toxic Burning Pits Area, 1992

\begin{tabular}{lrrrrrr}
\hline & \multicolumn{7}{c}{ VOC Concentrations ( $\mu$ g/L) } \\
\cline { 2 - 7 } Well $^{\mathrm{a}}$ & 112TCE & 12DCE & C2H3CL $^{\mathrm{b}}$ & TCLEA & TCLEE & TRCLE \\
\hline P3 & ND $^{\mathrm{c}}$ & 980 & 600 & ND & 3,400 & 570 \\
P4 & 65 & 3,300 & ND & ND & ND & 3,600 \\
P9 & ND & ND & 10 & ND & ND & ND \\
JF53 & 290 & 10,000 & 95 & 4,900 & ND & 4,200 \\
JF52 & 1 & 140 & ND & 1 & ND & 3 \\
JF51 & ND & 210 & ND & ND & ND & 97 \\
JF63 & ND & 120 & ND & 75 & 130 & 4,400 \\
JF62 & ND & 4 & ND & ND & ND & 13 \\
JF61 & ND & 2 & ND & ND & 2 & 10 \\
JF73 & 90 & 920 & ND & 9,000 & 280 & 5,100 \\
JF71 & ND & ND & ND & 2 & ND & 3 \\
JF83 & 2,000 & 12,000 & ND & 260,000 & 3,600 & 41,000 \\
JF82 & ND & 190 & ND & ND & ND & 1,800 \\
JF81 & ND & 22 & ND & 5 & 3 & 220 \\
\hline
\end{tabular}

a TBP wells not listed contained no VOCs. No data were obtained for wells P1, P2, JF43, 42, 41, and JF72.

b $\mathrm{C} 2 \mathrm{H} 3 \mathrm{CL}=$ vinyl chloride.

c $\mathrm{ND}=$ not detected.

Source: USGS (1992). 
the surficial aquifer south of the main burning pits - TRCLE increased from 4,900 $\mu \mathrm{g} / \mathrm{L}$ in 1990 to $41,000 \mu \mathrm{g} / \mathrm{L}$ in 1992 , TCLEE increased from $1,000 \mu \mathrm{g} / \mathrm{L}$ to $3,600 \mu \mathrm{g} / \mathrm{L}$, TCLEA increased from $250 \mu \mathrm{g} / \mathrm{L}$ to $260,000 \mu \mathrm{g} / \mathrm{L}$, and $12 \mathrm{DCE}$ increased from $7,150 \mu \mathrm{g} / \mathrm{L}$ to $12,000 \mu \mathrm{g} / \mathrm{L}$. Concentrations of $112 \mathrm{TCE}$ decreased from $7,100 \mu \mathrm{g} / \mathrm{L}$ in 1990 to $2,000 \mu \mathrm{g} / \mathrm{L}$ in 1992 (USGS 1992).

\subsubsection{Potential Pathways of Contaminant Migration}

Existing data indicate that the main pathway of contaminant migration at the TBP AOC is movement through the vadose zone down into the groundwater and then transport by groundwater.

Contaminants are apparently moving from their source, down into the groundwater, and then downgradient into the marshes by surficial aquifer discharge or into the estuaries by groundwater upwelling, or to locations even farther downgradient.

The direction of groundwater movement in the Talbot aquifers appears to be away from the TBP AOC toward the low-lying marshes and under the Gunpowder and Bush rivers. However, the lateral gradients in the lower aquifers are quite small (USGS 1991). The vertical movement of groundwater appears to be down through the aquifers; however, offshore there may be upward flow from each of the three Talbot aquifers into the Gunpowder and Bush rivers. Movement in the surficial and confined aquifers is affected by the tides (USGS 1991).

Surface water and associated sediment transport may play some role in contaminant migration in that surface runoff, particularly after intense storms, may carry dissolved and suspended contaminants from the contaminated areas into the marshes and estuaries. Surface water percolating through and leaching contaminated soils may be a major pathway by which contaminants, especially metals and VOCs, move down into the groundwater. Any contaminants that may have been present in the past in sufficient quantities to exist as free liquid in the soil would be expected to migrate down, independent of the presence of water.

Because of the generally humid conditions in the J-Field study area, wind transport of contaminated soil in areas with a good vegetative cover is expected to be minor. Diffusion of contaminated soil gas into the atmosphere and direct volatilization of contaminants from the soil are also expected to be minor release mechanisms. However, because portions of the TBP AOC are unvegetated or are sparsely covered with stressed vegetation, the air pathway may be significant and will be investigated. 


\subsubsection{White Phosphorus Burning Pits}

\subsubsection{Types of Waste Present}

The WPP area was used for the disposal of WP, PWP, and other related chemicals. It is also possible that riot control agents such as CN and TRCLE were disposed of in the WPP (Nemeth 1989).

\subsubsection{Types of Contaminants Present}

The first phase of the USGS hydrological assessment was conducted to select locations for monitoring wells at the TBP and WPP. It was assumed that the pits and the open burning grounds around them are the primary sources of contamination. The following subsections discuss the findings relative to the nature and extent of contamination in the WPP area.

\section{Soil Gas}

During Phase I of the hydrological assessment, the USGS sampled 35 locations around the WPP for soil-gas concentrations of TRCLE, TCLEE, combined hydrocarbons, and simple aromatics. The highest relative flux values of contamination were found north of the pits and to the west along the shore of Gunpowder River. Isolated areas of contamination were found to the south. The relative flux contours for TCLEE, shown in Figure 2.15, are similar to those for the other measured contaminants. However, the simple aromatics contamination north of the pits is more extensive than is shown in Figure 2.15 (Hughes 1993).

\section{Soil}

In 1983, soil samples were collected from each of the four monitor well boreholes at the WPP (Figure 2.16). For each borehole, one sample was obtained as a composite of samples collected over 5-ft intervals. The samples were analyzed for metals, cyanide, phenols, total phosphorus, VOCs, pesticides, PCBs, and herbicides.

The only significant contamination found was lead, at $1,360 \mathrm{mg} / \mathrm{kg}$ in the sample from borehole JBP-4. Arsenic (10 mg/kg), barium (208 $\mathrm{mg} / \mathrm{kg}$ ), and possibly cadmium $(1.33 \mathrm{mg} / \mathrm{kg}$ ) were found in the same sample. No VOCs were found in any of the samples at a detection limit of $5 \mu \mathrm{g} / \mathrm{kg}$. Cyanide was not found at a detection limit of $20 \mu \mathrm{g} / \mathrm{kg}$. Samples from the other boreholes showed essentially no contamination (Princeton Aqua Science 1984). One composite sample was collected from each of the two main pits in the WPP AOC. The samples from the pits, along with background samples, were analyzed for several chemical parameters (Table 2.13). The results show significant levels of lead (up to $2,960 \mathrm{mg} / \mathrm{kg}$ ) and 


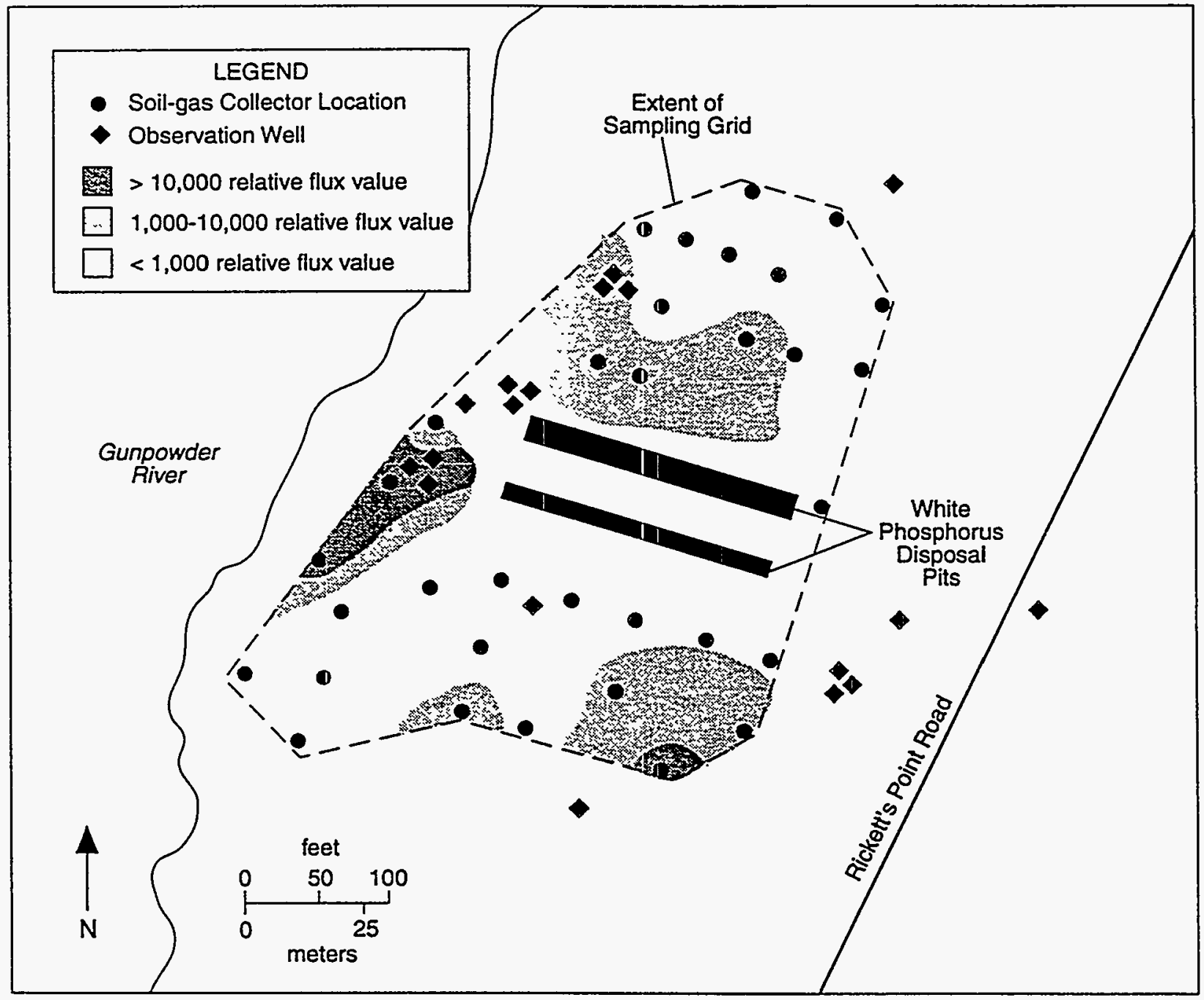

FIGURE 2.15 Relative Flux Contours for TCLEE at the White Phosphorus Pits (Source: Adapted from Hughes 1993)

zinc (up to $2,720 \mathrm{mg} / \mathrm{kg}$ ) in each sample. High concentrations of petroleum hydrocarbons (up to $5,800 \mathrm{mg} / \mathrm{kg}$ ) were also detected. The elevated levels of petroleum hydrocarbons in the background samples $(62 \mathrm{mg} / \mathrm{kg}$ ) indicate that these samples were collected at contaminated locations. Elevated levels of phosphorus (up to $1,573 \mathrm{mg} / \mathrm{kg}$ ) were also detected in the WPP samples.

As part of the 1986 RFA (Nemeth 1989), surface soil samples were collected at two locations (J31 and J32) in and around the WPP. Figure 2.17 shows the sampling locations. The samples were analyzed for metals, extractable metals, and explosives-related compounds. The results, as summarized in Table 2.14, show that the surface soil in and around the WPP contained elevated levels of metals, especially lead (up to $255 \mathrm{mg} / \mathrm{kg}$ ), chromium (up to $28.9 \mathrm{mg} / \mathrm{kg}$ ), cadmium (up to $2.40 \mathrm{mg} / \mathrm{kg}$ ), and barium (up to $149 \mathrm{mg} / \mathrm{kg}$ ). Neither of the two samples exceeded the RCRA EP limits for metals. 


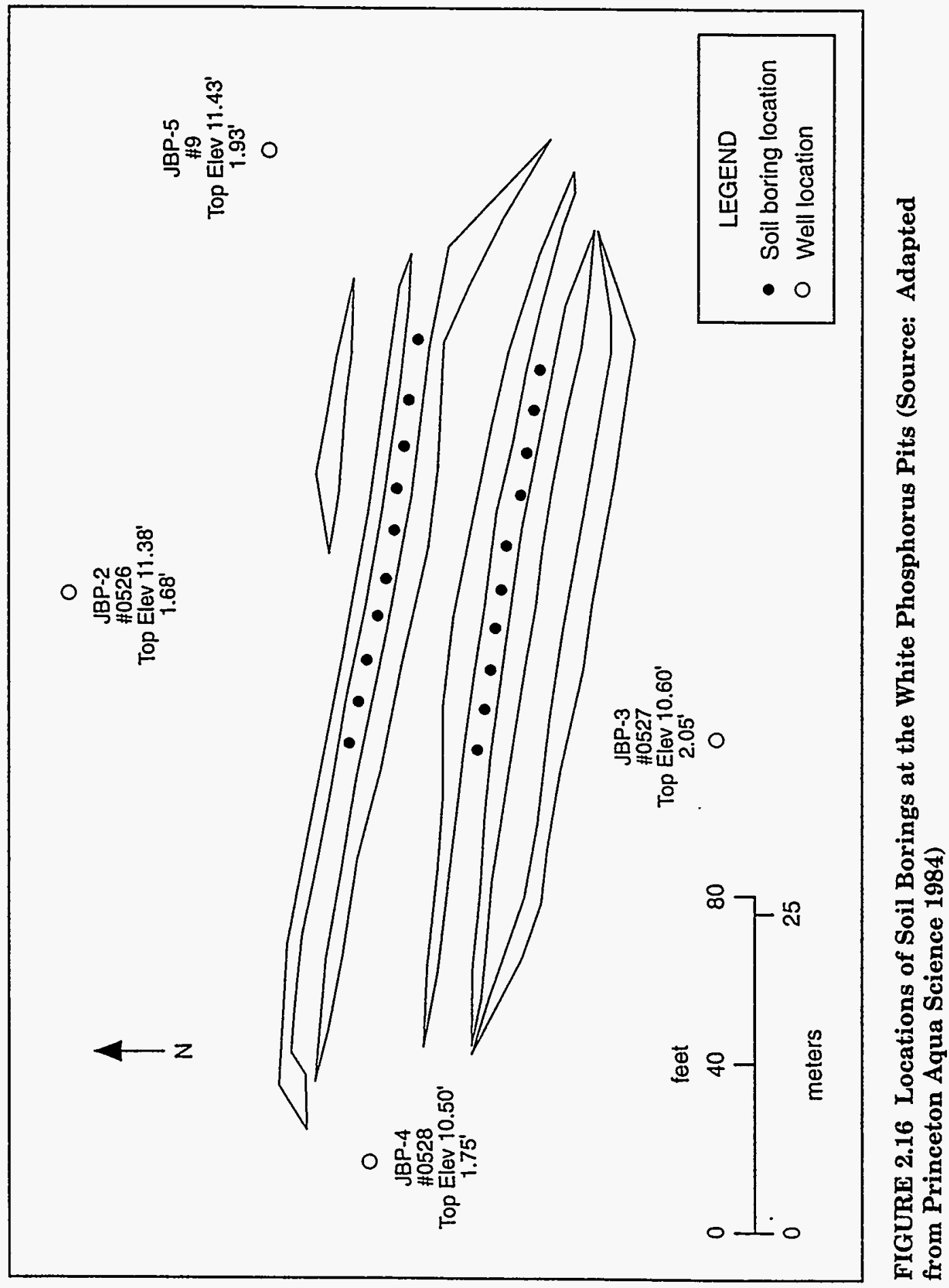


TABLE 2.13 Concentrations of Chemical Parameters in Soil from the White Phosphorus Pits at J-Field

\begin{tabular}{|c|c|c|c|}
\hline \multirow[b]{2}{*}{ Parameter $^{a}$} & \multicolumn{3}{|c|}{ Concentration $^{\mathrm{b}}(\mathrm{mg} / \mathrm{kg}$, unless noted) } \\
\hline & Background ${ }^{\mathbf{c}}$ & Pit $1^{d}$ & Pit $2^{d}$ \\
\hline Arsenic & 1.46 & 2.93 & 0.915 \\
\hline Barium & 247 & 939 & 525 \\
\hline Cadmium & 0.519 & 6.70 & 2.74 \\
\hline Chromium & 34.3 & 203 & 183 \\
\hline Iron & 14,800 & 18,100 & 17,900 \\
\hline Lead & 889 & 2,960 & 1,310 \\
\hline Manganese & 267 & 260 & 197 \\
\hline Mercury & 0.042 & 0.037 & 0.065 \\
\hline Potassium & 2,420 & 2,260 & 2,520 \\
\hline Zinc & 45.4 & 2,530 & 2,720 \\
\hline pH (standard units) & 6.9 & 7.7 & 6.8 \\
\hline Nitrate & 202 & 498 & 136 \\
\hline Total phosphorus & 26 & 220 & 1,573 \\
\hline Cyanide & $<0.5$ & $<0.5$ & 0.77 \\
\hline Petroleum hydrocarbons & 62 & 2,260 & 5,800 \\
\hline Phenols & $<0.130$ & $<0.134$ & 0.636 \\
\hline \multicolumn{4}{|l|}{ Aromatics } \\
\hline Toluene $(\mu \mathrm{g} / \mathrm{kg})$ & 45.8 & 75.6 & 27.4 \\
\hline Ethylbenzene ( $\mu \mathrm{g} / \mathrm{kg})$ & $<20$ & $<20$ & 51.6 \\
\hline
\end{tabular}

a Table lists parameters detected in at least one sample. Parameters measured but not detected are other aromatics $(<20 \mu \mathrm{g} / \mathrm{kg})$, VOCs $(<10 \mu \mathrm{g} / \mathrm{kg})$, herbicides $(<10 \mu \mathrm{g} / \mathrm{kg})$, pesticides $(<20 \mu \mathrm{g} / \mathrm{kg})$, and PCBs $(<10,000 \mu \mathrm{g} / \mathrm{kg})$.

b Results are based on composite soil samples taken in January 1983.

c Locations of background samples not given.

d Based on available information, it is inferred that Pit 1 is the northern pit and Pit 2 is the southern pit.

Source: Adapted from Princeton Aqua Science (1984). 


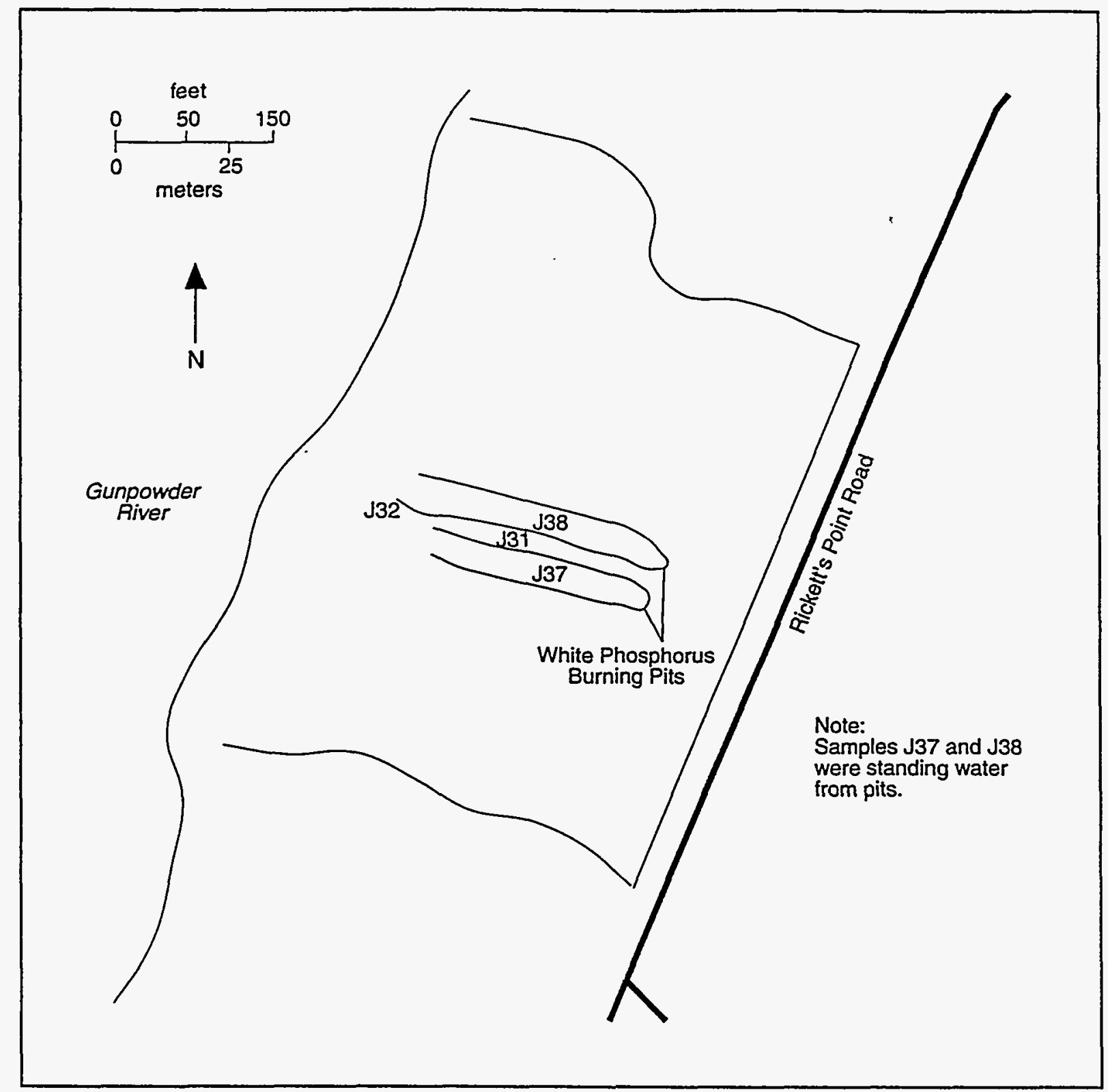

FIGURE 2.17 Locations of Surface Soil (J31 and J32) and Surface Water Samples (J37 and J38) in the White Phosphorus Pits Area (Source: Adapted from Hughes 1993)

The USGS collected soil samples (at approximately 1-ft depths) from 36 sites in J-Field, including the WPP area (Figure 2.15). The samples were analyzed for indicator parameters, metals, VOCs, semivolatile compounds, and explosives (Hughes 1992). The results are presented in Table 2.15. Levels of metals were fairly low, except that at location 1 (just east of the pits) the concentration of zinc was $942 \mathrm{mg} / \mathrm{kg}$. No VOCs were detected.

Soil samples were also collected in the WPP area by Weston in October 1992. Samples were collected at depths of 2 and $4 \mathrm{ft}$ in the pits and at depths of $3 \mathrm{in}$. and $1 \mathrm{ft}$ in the marshes and pushout areas. Table 2.16 summarizes the analytic results for parameters detected in some of these samples. 


\section{Surface Water}

Surface water samples (J37 and J38) were collected from the WPP area as part of the 1986 RFA (Nemeth 1989). Sampling locations are shown in Figure 2.11. Samples were analyzed for metals, explosives-related compounds, inorganic compounds, gross alpha and beta, VOCs, BNAs, pesticides, and PCBs. The results are summarized in Table 2.17 for locations J37 and J38.

The surface water contained some lead contamination. Sulfate and total dissolved solids (TDS) were slightly elevated in the WPP surface water, and gross alpha was also slightly elevated. None of the values for the other radioactive parameters was indicative of contamination.

Surface water samples were collected by the USGS at low tide close to the J-Field shore in the Gunpowder River (four locations near the WPP). One sample was collected onshore in a drainage ditch. Locations are shown in Figure 2.11. Filtered and unfiltered samples were analyzed for water quality parameters, metals, and a few organic compounds. A sample taken at location $3 \mathrm{had}$ nitrate concentrations of $380 \mu \mathrm{g} / \mathrm{L}$. The metals data showed low concentrations of lead (ND to $28 \mu \mathrm{g} / \mathrm{L}$ ) and zinc (50 to $133 \mu \mathrm{g} / \mathrm{L}$ ) at locations 1 to 4 . Mercury and nickel concentrations were slightly elevated at location 1 (0.54 and $33.7 \mu \mathrm{g} / \mathrm{L}$, respectively). No evidence was found of arsenic, barium, or chromium contamination. Comparison of data for filtered and unfiltered samples indicates that the slightly elevated metals concentrations may be associated with the suspended solids in the samples. This conclusion is based on the lower concentrations of metals in filtered samples for the few locations where both filtered and unfiltered data were obtained (Hughes 1993).

A few organic constituents (acetone, toluene, phenol, TOC, and TOX) were measured in samples from two locations. TOC and TOX were detected in the unfiltered samples only (4,000 and $21.6 \mu \mathrm{g} / \mathrm{L}$, respectively). Toluene was found only at location $1(3.05 \mu \mathrm{g} / \mathrm{L})$ (Hughes 1993).

In general, the nearshore surface water samples collected to date show little contamination. What contamination there is appears to be associated with the suspended solids. This suggests that the nearshore sediments may be contaminated. Additional data are needed to evaluate this situation. No data are available on concentrations of pollutants in surface water or sediments in the marshes on J-Field. 
TABLE 2.15 Analytical Results for Soil Samples from the White Phosphorus Pits Area, April 1991

\begin{tabular}{|c|c|c|c|c|c|c|c|c|c|c|}
\hline \multirow[b]{2}{*}{ Parameter } & \multicolumn{10}{|c|}{ Concentrations by Soil Sample Location } \\
\hline & 1 & 2 & 3 & 4 & 5 & 6 & 7 & 8 & 9 & 10 \\
\hline \multicolumn{11}{|l|}{ Metals (mg/kg) } \\
\hline Arsenic & 4.2 & 2.7 & 2.8 & 2.3 & $\mathrm{ND}^{\mathrm{a}}$ & ND & ND & ND & 2.9 & 2.9 \\
\hline Cadmium & ND & ND & ND & ND & ND & ND & ND & ND & ND & ND \\
\hline Chromium & 16 & 12 & 12 & 8.9 & 9.6 & 8.8 & 11 & 9.7 & 13 & 11 \\
\hline Copper & 42 & 3.8 & 20 & 3.6 & 5.0 & 4.7 & 11 & 6.1 & 6.3 & 9.9 \\
\hline Lead & ND & 25 & 41 & 5.3 & 19 & 18 & 15 & 18 & 15 & 17 \\
\hline Antimony & ND & ND & ND & ND & ND & ND & ND & ND & ND & ND \\
\hline Zinc & 942 & ND & ND & 18 & ND & ND & ND & ND & ND & 26 \\
\hline \multicolumn{11}{|c|}{ Volatile Organic Compounds ( $\mu \mathrm{g} / \mathrm{kg}$ ) } \\
\hline Acetone & ND & ND & ND & ND & ND & ND & ND & ND & ND & ND \\
\hline Trichloroethylene & ND & ND & ND & ND & ND & ND & ND & ND & ND & ND \\
\hline \multicolumn{11}{|c|}{ Semivolatile Organic Compounds ( $\mu \mathrm{g} / \mathrm{kg}$ ) } \\
\hline Butylbenzyl phthalate & ND & ND & ND & ND & ND & ND & ND & ND & ND & ND \\
\hline Benzoic acid & ND & ND & ND & ND & ND & ND & ND & ND & ND & ND \\
\hline Di-n-butyl phthalate & 4,830 & ND & ND & ND & ND & ND & ND & ND & ND & ND \\
\hline
\end{tabular}

a $\mathrm{ND}=$ not detected.

Source: Hughes (1992). 
TABLE 2.16 Analytical Results for TCL and TAL Analytes in Selected Soil Samples from the

White Phosphorus Pits, $1992^{\mathrm{a}}$

\begin{tabular}{|c|c|c|c|c|c|c|}
\hline \multirow[b]{2}{*}{ Parameter } & \multicolumn{6}{|c|}{ Concentrations by Soil Sample Location } \\
\hline & JWP1-E $\left(2^{\prime}\right)^{b}$ & JWP1-E(4') & JWP2-E(2) & JWP2-E(4') & JWPM-A(3") & JWPM-A(1') \\
\hline \multicolumn{7}{|c|}{ Volatile Organic Compounds ( $\mu \mathrm{g} / \mathrm{kg})$} \\
\hline Methylene chloride & $\mathrm{ND}^{\mathrm{c}}$ & ND & 9.53 & 15.2 & 13.4 & ND \\
\hline Acetone & 494 & 156 & 165 & 38.9 & 185 & 21.5 \\
\hline Toluene & ND & ND & ND & ND & ND & ND \\
\hline Xylenes & ND & 16.6 & ND & ND & 11.2 & 9.17 \\
\hline \multicolumn{7}{|l|}{$P C B s(\mu g / k g)$} \\
\hline Aroclor 1254 & ND & ND & ND & $\mathrm{ND}$ & ND & ND \\
\hline Aroclor 1260 & ND & ND & ND & ND & ND & ND \\
\hline \multicolumn{7}{|l|}{ TAL Analytes (mg/kg) } \\
\hline Antimony & ND & ND & ND & ND & 5.92 & ND \\
\hline Arsenic & 3.22 & 2.24 & 2.82 & ND & 4.20 & 2.46 \\
\hline Beryllium & 0.279 & 0.796 & 0.520 & ND & 0.318 & 0.335 \\
\hline Cadmium & ND & 0.626 & ND & $\mathrm{ND}$ & 2.02 & $\mathrm{ND}$ \\
\hline Chromium & 11.6 & 12.8 & 16.7 & 4.93 & 15.8 & 7.53 \\
\hline Cobalt & ND & ND & ND & ND & ND & ND \\
\hline Copper & 10.5 & 8.63 & 8.40 & ND & 59.4 & 11.0 \\
\hline Lead & 8.37 & 8.87 & 6.46 & 4.89 & 209 & 44.3 \\
\hline Zinc & 24.0 & 62.5 & 13.0 & 19.7 & 284 & 37.9 \\
\hline Nickel & ND & 13.7 & ND & 6.18 & ND & ND \\
\hline
\end{tabular}


TABLE 2.16 (Cont.)

\begin{tabular}{|c|c|c|c|c|c|c|}
\hline \multirow[b]{2}{*}{ Parameter } & \multicolumn{6}{|c|}{ Concentrations by Soil Sample Location } \\
\hline & JWPM-C(3") & JWPM-C(1') & JWPP-A(3") & JWPP-A(1') & JWPP-C(3") & JWPP-C(1') \\
\hline \multicolumn{7}{|c|}{ Volatile Organic Compounds ( $\mu \mathrm{g} / \mathrm{kg}$ ) } \\
\hline Methylene chloride & 10.8 & 5.83 & 17.0 & 7.51 & 9.29 & 8.35 \\
\hline Acetone & 16.1 & 45.0 & ND & 252 & ND & 178 \\
\hline Toluene & 7.42 & ND & ND & ND & ND & 6.54 \\
\hline Xylenes & 18.4 & ND & ND & ND & $\mathrm{ND}$ & 11.8 \\
\hline \multicolumn{7}{|l|}{ PCBs ( $\mu \mathrm{g} / \mathrm{kg})$} \\
\hline Aroclor 1254 & ND & ND & ND & ND & 323 & ND \\
\hline Aroclor 1260 & 215 & ND & ND & ND & $\mathrm{ND}$ & ND \\
\hline \multicolumn{7}{|l|}{ TAL Analytes (mg/kg) } \\
\hline Antimony & ND & ND & ND & ND & 10.2 & ND \\
\hline Arsenic & 4.00 & 1.96 & 4.48 & 2.60 & 3.29 & 3.55 \\
\hline Beryllium & 0.239 & 0.182 & 0.254 & 0.218 & 0.267 & 0.308 \\
\hline Cadmium & 2.11 & ND & ND & ND & 1.62 & 0.576 \\
\hline Chromium & 20.8 & 8.37 & 12.4 & 10.6 & 21.9 & 9.83 \\
\hline Cobalt & ND & ND & ND & ND & ND & ND \\
\hline Copper & 111 & $\mathrm{ND}$ & 10.4 & ND & 109 & 19.8 \\
\hline Lead & 556 & 7.29 & 23.2 & 25.0 & 235 & 156 \\
\hline Zinc & 15.2 & 7.57 & 109 & 34.9 & 651 & 257 \\
\hline Nickel & 1,080 & 24.6 & 8.27 & 8.18 & 9.65 & 9.47 \\
\hline
\end{tabular}

a Only detected analytes are reported; for samples with duplicate analyses, the higher value is reported.

b Sample depth shown in parentheses.

c $\mathrm{ND}=$ not detected.

Source: Mazelon (1993). 
TABLE 2.17 Analytical Results for Surface

Water Samples from the White Phosphorus

Pits Area, 1986

\begin{tabular}{|c|c|c|}
\hline \multirow[b]{2}{*}{ Parameter } & \multicolumn{2}{|c|}{ Location } \\
\hline & J37 & J38 \\
\hline \multicolumn{3}{|l|}{ Dissolved Metals ( $\mu g / L)$} \\
\hline Cadmium & $<1.0$ & 3.0 \\
\hline Lead & 6.0 & 44 \\
\hline Mercury & $<0.20$ & $<0.20$ \\
\hline \multicolumn{3}{|c|}{ Inorganic Compounds (ug/L) } \\
\hline Nitrate and nitrite as $\mathrm{N}$ & $<30$ & 200 \\
\hline Sulfate & 160,000 & 15,000 \\
\hline Chloride & 5,000 & 3,000 \\
\hline Total dissolved solids & 388,000 & 114,000 \\
\hline \multicolumn{3}{|l|}{ Radioactivity (pCi/L) } \\
\hline Gross alpha & 2.8 & 4.2 \\
\hline Gross beta & 8.0 & 8.7 \\
\hline
\end{tabular}

Source: Nemeth (1989).

\section{Groundwater}

Three monitoring wells (designated TH) were installed at the WPP in 1977 (Figure 2.13) as part of an environmental contamination survey conducted by USATHAMA (Nemeth 1989). The depth of the wells ranged from 20 to $25 \mathrm{ft}$. The wells were screened in the surficial aquifer (Sonntag 1991). Water samples collected from the wells in 1977 were analyzed for metals, indicator chemicals, WP, mustard degradation products, cholinesterase inhibitors, BNAs, and VOCs.

Low levels of organic contamination were found in all wells. A mustard degradation product, 1,3-dithiane, was found at a concentration of $6 \mu \mathrm{g} / \mathrm{L}$ in well TH1 near the WPP. Aliphatic and aromatic organic compounds were found at levels up to $200 \mu \mathrm{g} / \mathrm{L}$ in most well samples. Organic compounds introduced by the well construction procedure or possible sample contamination were found at higher concentrations (e.g., tetrahydrofuran up to $8,000 \mu \mathrm{g} / \mathrm{L})$.

Four additional wells were installed around the WPP (wells P5-P8 in Figure 2.13) as part of a munitions disposal study (Princeton Aqua Science 1984). The wells were 17-20 ft deep and were screened with 15-ft-long screens in the surficial aquifer (Sonntag 1991). Samples collected from the wells in 1983 were analyzed for metals, nitrate, TOX, TOC, radioactivity, some pesticides and herbicides, and secondary drinking water contaminants. Analyses indicated no major concentrations of metals, pesticides, or herbicides. 
Samples collected from these four wells in 1986 as part of an RFA (Nemeth 1989) were analyzed for metals, explosives-related compounds, indicator parameters, radioactivity, thiodiglycol, VOCs, BNAs, pesticides, and PCBs. Sulfate, TDS, and TRCLE were the only parameters that showed any elevated concentrations.

Twelve additional monitor wells were installed at the WPP in late 1988 and 1989 by the USGS (Sonntag 1991; Hughes 1993). The wells were installed as three-well nests at four different locations (Figure 2.13). At each site, the three wells were screened in the confined aquifer, the leaky confined unit, and the surficial aquifer of the Talbot Formation. The groundwater samples collected from the nested wells were analyzed for metals, other inorganic parameters, VOCs, and semivolatile organic compounds. Some analyses were performed for organosulfur, explosives-related, and radioactive compounds. Wells were selected for these analyses on the basis of their proximity to potential disposal areas for these materials (USGS 1991).

Potassium concentrations detected in the samples varied considerably, with most ranging from ND to $10 \mu \mathrm{g} / \mathrm{L}$. All of the elevated values (above $50 \mu \mathrm{g} / \mathrm{L}$ ) occurred in the leaky confined unit or the confined aquifer. Movement of sea water into the groundwater does not appear to be the source of the potassium, because wells with elevated potassium concentrations did not have elevated chloride concentrations.

Low levels of VOC contamination were detected in the WPP. Only one well, P8, showed contamination by TRCLE $(40 \mu \mathrm{g} / \mathrm{L})$. Some contamination by other VOCs was detected in wells P7 and JF10-2. (Acetone is excluded because of the possibility that its presence is a result of laboratory quality control $[Q C]$ procedures.)

\subsubsection{Potential Pathways of Contaminant Migration}

Existing data indicate that the main pathway of contaminant migration at the WPP AOC is movement through the vadose zone down into the groundwater and then transport by the groundwater.

The direction of groundwater movement in the Talbot aquifers appears to be away from the WPP AOC toward the Gunpowder River. However, the lateral gradients in the lower aquifers are quite small (USGS 1991). The vertical movement of groundwater appears to be down through the aquifers; however, offshore there may be upward flow from each of the three Talbot aquifers into the Gunpowder and Bush rivers. Movement in the surficial and confined aquifers is affected by the tides (USGS 1991).

Surface water and associated sediment transport may play some role in contaminant migration in that surface runoff, particularly after intense storms, may carry dissolved and suspended contaminants from the contaminated areas into the marshes and estuaries. Lateral contaminant migration by surface water is expected to be minor (Sonntag 1991). However, in the past, the surface water pathway may have been more significant because the pits were operated to allow drainage to flow to the Gunpowder River (Weston 1992). Surface 
water percolating through and leaching contaminated soils may be a major pathway by which contaminants, especially metals and VOCs, move down into the groundwater. Any contaminants that may have been present in the past in sufficient amounts to exist as free liquid in the soil would be expected to migrate downward, independent of the presence of water.

Because of the generally humid conditions in the J-Field study area, wind transport of contaminated soil in areas with a good vegetative cover is expected to be minor. Diffusion of contaminated soil gas into the atmosphere and direct volatilization of contaminants from the soil are also expected to be minor release mechanisms. However, because portions of the WPP AOC are unvegetated or are sparsely covered with stressed vegetation, and because at least part of the WPP AOC is expected to be used for OB/OD, the air pathway may be significant and will be investigated.

\subsubsection{Riot Control Burning Pit}

\subsubsection{Types of Waste Present}

The RCP area was used for burning of riot control agents and disposing of munitions filled with riot control agents and of materials contaminated with these chemicals. The primary riot control chemicals disposed of in the burning pit were tear agents (CS and possibly $\mathrm{CN}$ ) and items contaminated with those agents.

\subsubsection{Types of Contaminants Present}

\section{Soil Gas}

Soil-gas sampling and analysis were conducted during Phase I of the USGS hydrological assessment. Soil-gas samples collected from 12 locations on a 100-ft grid around the RCP were analyzed for TRCLE, TCLEE, alkanes, combined hydrocarbons, and simple aromatics. Relative flux values indicated contamination by chlorinated solvents at areas north and south of the pits. Contamination by phthalates and heavy aromatic compounds appeared to be more extensive, with phthalates showing elevated contamination along Rickett's Point Road and at one location south of the pit. The highest measured flux value for aromatic compounds was at a location south of the pit. Figure 2.18 shows the relative flux contours for heavy aromatics at the pit.

\section{Soil}

A soil sample was collected immediately northeast of the disposal trench during the 1986 RFA (Nemeth 1989). That sample contained a significant amount of ash and other residue from burning operations; analysis showed slightly elevated levels of total cadmium, chromium, lead, and silver, and very low levels of polyaromatic hydrocarbons (PAHs). 


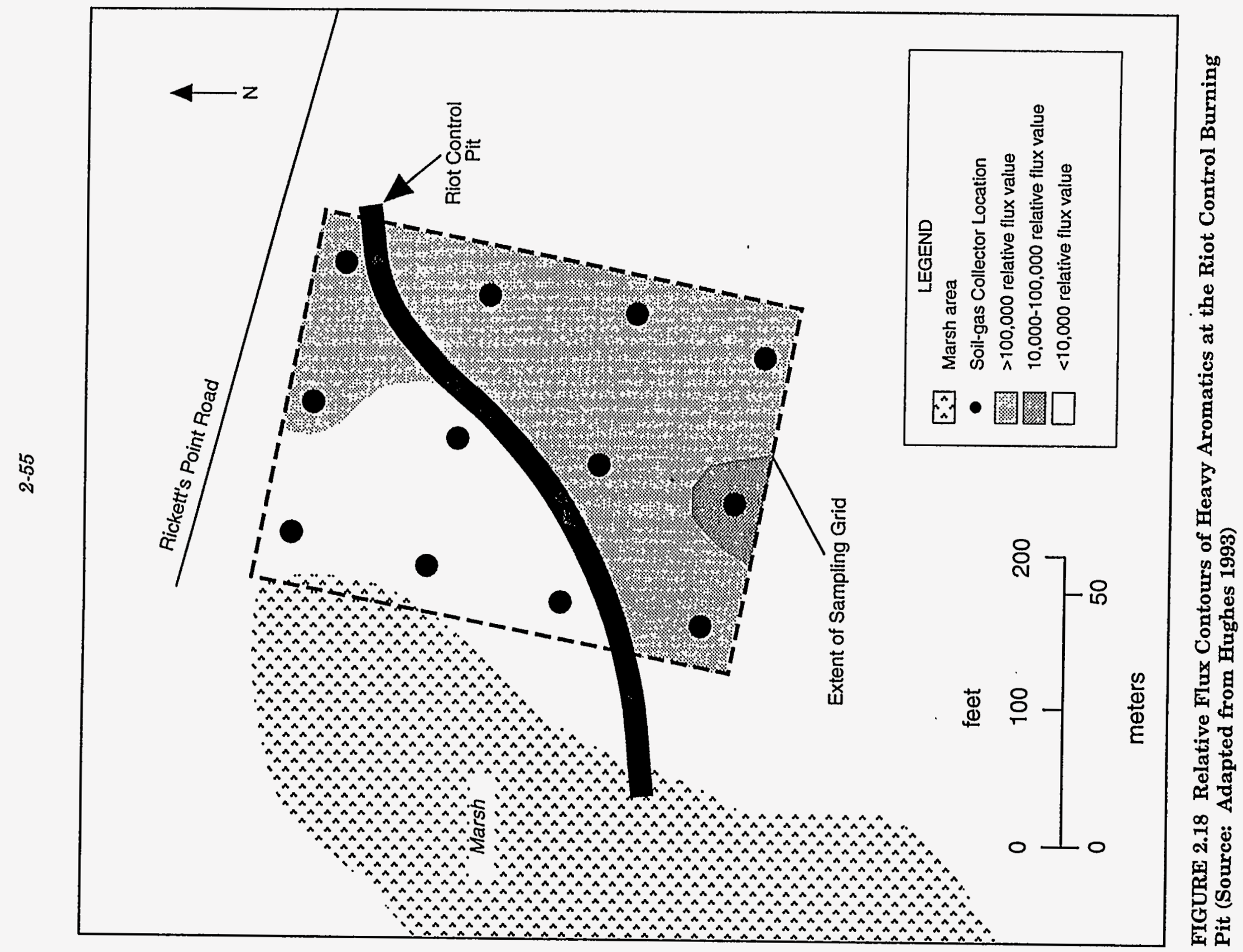


Soil samples were collected by the USGS at 36 sites at J-Field, including the RCP area (locations 16 through 20 in Figure 2.9). The samples were collected at 1-ft depths and were analyzed for indicator parameters, metals, VOCs, semivolatile compounds, and explosives-related compounds (Hughes 1992). The results of the analyses are presented in Table 2.18. Soil samples showed some metals contamination, especially at locations 16,17 , and 18 north of the pit, where lead concentrations ranged from 34 to $68 \mathrm{mg} / \mathrm{kg}$. Zinc was found at $158 \mathrm{mg} / \mathrm{kg}$ at location 16. Organic compounds (acetone, butylbenzyl phthalate, and benzoic acid) were also detected in some samples.

Soil samples were also collected in the RCP area by Weston in October 1992 (Figure 2.19). The samples were collected at 3-in., 2-ft, and 4-ft depths in the pit and at 3-in. and 1-ft depths in the marshes and pushout areas. Tables 2.19 and 2.20 summarize the analytic results for parameters detected in some of these samples. The data indicate that several areas are contaminated with metals, mainly at the surface (within 3 in. to $2 \mathrm{ft}$ ). The highest concentrations of lead were found in the center of the RCP (up to $339 \mathrm{mg} / \mathrm{kg}$ at $3 \mathrm{in}$.). Lead concentrations ranged from 31 to $90 \mathrm{mg} / \mathrm{kg}$ at the ends of the pit, in the marshes, and in the pushout areas. Other metals detected include beryllium, up to $0.451 \mathrm{mg} / \mathrm{kg}$ in the marsh east of the RCP; chromium, up to $106 \mathrm{mg} / \mathrm{kg}$ at the eastern end of the RCP; copper, up to $742 \mathrm{mg} / \mathrm{kg}$ at the eastern end of the RCP; and zinc, up to $742 \mathrm{mg} / \mathrm{kg}$ in the center of the RCP. Organic compounds were also detected, including benzoic acid, chlorobenzene, di-nbutyl phthalate, acetone, methylene chloride, styrene, toluene, xylene, and pesticides. PCBs were not detected.

TABLE 2.18 Analytical Results for Soil Samples from the Riot Control Burning Pit Area, April 1991

\begin{tabular}{|c|c|c|c|c|c|c|c|}
\hline \multirow[b]{2}{*}{ Parameter } & \multicolumn{7}{|c|}{ Concentration by Soil Sample Location } \\
\hline & 16 & 17 & 18 & 19 & 20 & 21 & 22 \\
\hline \multicolumn{8}{|l|}{ Metals (mg/kg) } \\
\hline Arsenic & 4.4 & 3.8 & 3.4 & 2.9 & 3.7 & 3.3 & $\mathrm{ND}^{\mathrm{a}}$ \\
\hline Cadmium & ND & ND & ND & ND & ND & ND & ND \\
\hline Chromium & 11 & 8.6 & 8.7 & 7.5 & 11 & 8.8 & 7.4 \\
\hline Copper & 9.5 & 10 & 9.5 & 5.4 & 7.0 & 7.2 & 15 \\
\hline Lead & 68 & 41 & 34 & 2.1 & 41 & 1.7 & 22 \\
\hline Antimony & ND & ND & ND & ND & ND & ND & ND \\
\hline Zinc & 158 & ND & ND & ND & ND & ND & ND \\
\hline \multicolumn{8}{|c|}{ Volatile Organic Compounds ( $\mu \mathrm{g} / \mathrm{kg}$ ) } \\
\hline Acetone & 7.27 & 29.6 & 9.01 & 6.47 & 10.2 & 9.51 & 2.45 \\
\hline Trichloroethylene & ND & ND & ND & ND & ND & ND & ND \\
\hline \multicolumn{8}{|c|}{ Semivolatile Organic Compounds ( $\mu \mathrm{g} / \mathrm{kg}$ ) } \\
\hline Butylbenzl phthalate & ND & ND & 528 & ND & ND & ND & 3,700 \\
\hline Benzoic acid & 3,400 & 12,000 & ND & 1,800 & 949 & 654 & 3,700 \\
\hline
\end{tabular}




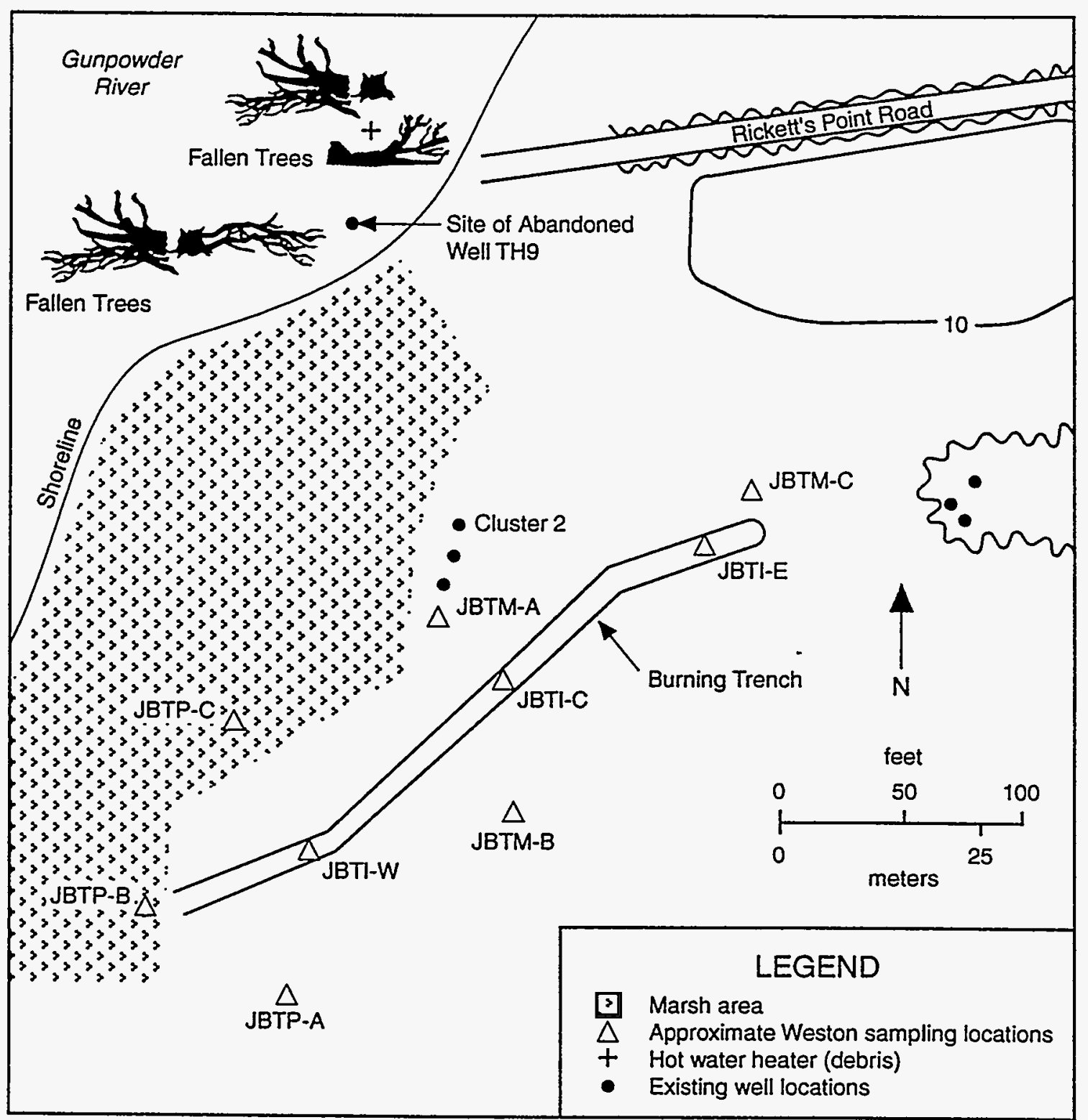

FIGURE 2.19 Locations of Soil Samples Collected by Weston in 1992 from the Riot Control Burning Pit (Source: Adapted from Mazelon 1993) 
TABLE 2.19 Analytical Results for TCL Analytes in Selected Soil Samples from the Riot Control Burning Pit Area, 1992

\begin{tabular}{|c|c|c|c|c|c|c|}
\hline \multirow[b]{2}{*}{ TCL Analyte } & \multicolumn{6}{|c|}{ Concentrations $(\mu \mathrm{g} / \mathrm{kg})$ by Soil Sample Location } \\
\hline & $\mathrm{JB}^{\prime} \mathrm{T} 1-\mathrm{E}\left(3^{\prime \prime}\right)^{\mathrm{b}}$ & JBT1-E(2') & JBT1-E(4') & JBP1-W(3") & JBT1-W(2) & JBT1-W(4) \\
\hline \multicolumn{7}{|l|}{ Volatile Organic Compounds } \\
\hline Acetone & 61.8 & 46.2 & 191 & 236 & 82.2 & 18.5 \\
\hline Benzene & $\mathrm{ND}^{\mathrm{c}}$ & ND & ND & ND & ND & ND \\
\hline Carbon disulfide & ND & ND & ND & ND & ND & $\mathrm{ND}$ \\
\hline Chloroform & ND & ND & ND & ND & ND & $\mathrm{ND}$ \\
\hline Chloroethane & ND & ND & ND & ND & ND & ND \\
\hline Chloromethane & 10.3 & 7.7 & 5.22 & 13.2 & 17.6 & 6.75 \\
\hline Styrene & ND & ND & ND & ND & ND & ND \\
\hline Toluene & ND & ND & ND & ND & ND & ND \\
\hline Xylenes & ND & ND & ND & ND & ND & ND \\
\hline \multicolumn{7}{|c|}{ Semivolatile Organic Compounds } \\
\hline 2-Methylnaphthalene & 52 & ND & ND & ND & $\mathrm{ND}$ & ND \\
\hline Benzoic acid & ND & ND & ND & 183 & 79.2 & 47.8 \\
\hline bis-(2-Chloromethyl) ether & ND & ND & ND & ND & ND & ND \\
\hline bis-(2-Ethylhexyl) phthalate & ND & ND & ND & ND & ND & ND \\
\hline Di-n-butyl phthalate & ND & ND & ND & 217 & 111 & 54.1 \\
\hline Fluoranthene & ND & ND & ND & ND & ND & ND \\
\hline Hexachlobenzene & ND & ND & ND & ND & ND & $\mathrm{ND}$ \\
\hline Pyrene & ND & ND & ND & ND & ND & ND \\
\hline \multicolumn{7}{|l|}{ Pesticides } \\
\hline $4,4^{\prime} \mathrm{DDD}$ & ND & ND & ND & ND & ND & ND \\
\hline 4,4-DDE & 2.22 & ND & ND & 10.6 & ND & $\mathrm{ND}$ \\
\hline $4,4^{\prime} \mathrm{DDT}$ & ND & ND & ND & ND & ND & ND \\
\hline \multicolumn{7}{|l|}{ PCBs } \\
\hline Aroclor 1248 & ND & ND & ND & ND & ND & ND \\
\hline Aroclor 1254 & ND & ND & ND & ND & ND & ND \\
\hline
\end{tabular}


TABLE 2.19 (Cont.)

Concentrations $(\mu \mathrm{g} / \mathrm{kg})$ by Soil Sample Location

\begin{tabular}{|c|c|c|c|c|c|c|c|c|}
\hline TCL Analyte & JBTM-A(3") & JBTM-A(1) & JBTM-C(3") & JBTM-C(1) & JBTP-A(3") & JBTP-A(1') & JBTP-C(3") & JBTP-C (1) \\
\hline \multicolumn{9}{|l|}{ Volatile Organic Compounds } \\
\hline Acetone & 171 & 55.4 & 169 & 91 & 70.4 & 74.3 & ND & ND \\
\hline Benzene & ND & $\mathrm{ND}$ & ND & 2.46 & ND & ND & ND & ND \\
\hline Carbon disulfide & ND & ND & ND & ND & 4.89 & ND & ND & ND \\
\hline Chloroform & $\mathrm{ND}$ & ND & ND & ND & ND & ND & 20.3 & ND \\
\hline Chloroethane & 12.2 & 2.72 & ND & ND & ND & ND & ND & ND \\
\hline Chloromethane & 10.2 & 5.75 & 5.87 & 9.75 & 12.2 & 5.69 & 5.69 & 3.26 \\
\hline Styrene & 8.57 & $\mathrm{ND}$ & ND & ND & ND & 18 & ND & $\mathrm{ND}$ \\
\hline Toluene & 42.3 & 16.2 & 7.9 & 1.77 & ND & 1.44 & ND & ND \\
\hline Xylenes & 159 & 77.2 & ND & ND & ND & $\mathrm{ND}$ & $\mathrm{ND}$ & ND \\
\hline \multicolumn{9}{|c|}{ Semivolatile Organic Compounds } \\
\hline 2-Methylnaphthalene & ND & ND & ND & ND & ND & ND & ND & ND \\
\hline Benzoic acid & 4,380 & 100 & ND & 63.6 & 840 & 336 & ND & 106 \\
\hline bis-(2-Chloromethyl) ether & 438 & ND & ND & $\mathrm{ND}$ & 64.5 & $\mathrm{ND}$ & 54 & ND \\
\hline bis-(2-Ethylhexyl) phthalate & $\mathrm{ND}$ & ND & ND & ND & ND & 41.5 & $\mathrm{ND}$ & ND \\
\hline Di-n-butyl phthalate & 126 & 53.5 & ND & $\mathrm{ND}$ & ND & ND & ND & 188 \\
\hline Fluoranthene & ND & ND & ND & ND & ND & ND & ND & ND \\
\hline Hexachlobenzene & $\mathrm{ND}$ & ND & ND & ND & ND & ND & ND & ND \\
\hline Pyrene & ND & $\mathrm{ND}$ & ND & ND & ND & ND & $\mathrm{ND}$ & $\mathrm{ND}$ \\
\hline \multicolumn{9}{|l|}{ Pesticides } \\
\hline 4,4'DDD & ND & ND & ND & ND & ND & ND & ND & $\mathrm{ND}$ \\
\hline 4,4' DDE & 32.9 & ND & ND & 1.79 & 10.1 & ND & 4.69 & ND \\
\hline $4,4^{\circ} \mathrm{DDT}$ & 8.28 & ND & ND & ND & ND & ND & ND & ND \\
\hline \multicolumn{9}{|l|}{$P C B s$} \\
\hline Aroclor 1248 & ND & ND & ND & ND & ND & $\mathrm{ND}$ & ND & ND \\
\hline Aroclor 1254 & $\mathrm{ND}$ & ND & ND & ND & ND & $\mathrm{ND}$ & ND & $\mathrm{ND}$ \\
\hline
\end{tabular}

a Only detected analytes are reported; for samples with duplicate analyses, the higher value is reported.

b Sample depth shown in parentheses.

c $\mathrm{ND}=$ not detected. 
TABLE 2.20 Analytical Results for TAL Analytes in Selected Soil Samples from the Riot Control Burning Pit Area, 1992 ${ }^{\mathrm{a}}$

\begin{tabular}{|c|c|c|c|c|c|c|c|}
\hline \multirow{2}{*}{$\begin{array}{c}\text { TAL } \\
\text { Analyte }\end{array}$} & \multicolumn{7}{|c|}{ Concentration (mg/kg) by Soil Sample Location } \\
\hline & $\mathrm{JBT} 1-\mathrm{E}\left(3^{\prime \prime}\right)^{\mathrm{b}}$ & JBT1-E(2') & $\mathrm{JBT} 1-\mathrm{E}\left(4^{\prime}\right)$ & JBT1-W(3") & JBT1-W(2') & JBT1-W(4') & JBTM-A(3") \\
\hline Antimony & $\mathrm{ND}^{\mathrm{c}}$ & 5.31 & ND & ND & $\mathrm{ND}$ & ND & $\mathrm{ND}$ \\
\hline Arsenic & 4.96 & 4.27 & ND & ND & 2.94 & 1.84 & 2.77 \\
\hline Beryllium & 0.374 & 0.343 & $\mathrm{ND}$ & 0.355 & 0.362 & 0.278 & 0.555 \\
\hline Cadmium & 5.24 & 2.73 & ND & 0.907 & 0.690 & ND & 0.994 \\
\hline Chromium & 106 & 40 & 11.9 & 11.3 & 17.3 & 16.6 & 14.2 \\
\hline Cobalt & $\mathrm{ND}$ & ND & ND & $\mathrm{ND}$ & ND & ND & ND \\
\hline Copper & 742 & 262 & 116 & 23.2 & ND & 9.79 & 12.3 \\
\hline Lead & 1.14 & 49.2 & 10.9 & 60.5 & 8.98 & 8.92 & 57.1 \\
\hline Zinc & 281 & 139 & 45.6 & 119 & 17.2 & 14.6 & 46.6 \\
\hline Nickel & 40.2 & 23.2 & 9.89 & ND & 9.08 & 8.01 & 12.6 \\
\hline
\end{tabular}

\begin{tabular}{|c|c|c|c|c|c|c|c|}
\hline \multirow{2}{*}{$\begin{array}{c}\text { TAL } \\
\text { Analyte }\end{array}$} & \multicolumn{7}{|c|}{ Concentration $(\mathrm{mg} / \mathrm{kg})$ by Soil Sample Location } \\
\hline & JBTM-A(1') & $\operatorname{JBTM}-\mathrm{C}\left(3^{\prime \prime}\right)$ & JBTM-C(1') & JBTP-A(3") & JBTP-A(1') & JBTP-C(3") & JBTP-C(1') \\
\hline Antimony & $\mathrm{ND}^{\mathbf{c}}$ & ND & $\mathrm{ND}$ & ND & ND & $\mathrm{ND}$ & $\mathrm{ND}$ \\
\hline Arsenic & ND & 1.87 & 1.72 & ND & 2.18 & 2.28 & 1.81 \\
\hline Beryllium & 0.337 & 0.451 & 0.279 & 0.418 & 0.328 & ND & 0.745 \\
\hline Cadmium & 0.586 & 0.898 & 0.696 & 1.7 & 0.601 & $\mathrm{ND}$ & ND \\
\hline Chromium & 8.06 & 12.1 & 11.1 & 12.6 & 14.2 & 14.1 & 24.3 \\
\hline Cobalt & ND & ND & $\mathrm{ND}$ & $\mathrm{ND}$ & $\mathrm{ND}$ & ND & ND \\
\hline Copper & $\mathrm{ND}$ & 9.01 & $\mathrm{ND}$ & 8.98 & ND & 11.3 & 9.41 \\
\hline Lead & 5.97 & 52.2 & 7.61 & 33.2 & 7.23 & 41.8 & 9.13 \\
\hline Zinc & 5.02 & 58.9 & 6.77 & 22.2 & 11.3 & 39.4 & 36.3 \\
\hline Nickel & ND & 8.27 & 7.16 & 17.5 & $\mathrm{ND}$ & ND & 11.2 \\
\hline
\end{tabular}

\footnotetext{
a Only detected analytes are reported; for samples with duplicate analyses, the higher value is reported.

b Sample depth shown in parentheses.

c $\mathrm{ND}=$ not detected.
} 


\section{Surface Water}

Surface water samples were collected by the USGS at low tide close to the shore near the RCP area (locations 7-12 in Figure 2.11). Both filtered and unfiltered samples were analyzed for major water quality parameters, metals, and a few organic compounds. Nitrate concentrations from location 7 ranged from 200 to $400 \mu \mathrm{g} / \mathrm{L}$. Phenol, TOC, and TOX were also detected in the unfiltered sample from location $7(51.9,7,000$, and $20 \mu \mathrm{g} / \mathrm{L}$, respectively). As described in Section 2.3.1.2, the USGS and the EPA ERT sampled surface water and sediment from areas offshore of the RCP.

In general, the nearshore surface water quality data from the samples collected to date show essentially no contamination. What contamination there is appears to be associated with the suspended solids. This finding suggests that the nearshore sediments may be contaminated.

\section{Groundwater}

Two monitoring wells (TH9 and TH10 in Figure 2.13) were installed near the RCP area as part of the 1977 environmental contamination survey (Nemeth 1989). The depth of the wells ranged from 20 to $25 \mathrm{ft}$. The wells were screened in the surficial aquifer (Sonntag 1991). Water samples collected from the wells in 1977 were analyzed for metals, indicator chemicals, WP, mustard degradation products, cholinesterase inhibitors, BNAs, and VOCs. Only very low levels of organic contamination were detected. Because of the erosion of the shoreline west of the RCP, well TH9 was abandoned, and the shoreline was stabilized with gabion baskets and riprap.

Two monitoring well nests (JF1 and JF2 in Figure 2.13) were installed near the RCP in late 1988 and 1989 by the USGS (Sonntag 1991; Hughes 1993). At each site, the wells were screened in the confined aquifer, the leaky confined unit, and the surficial aquifer of the Talbot Formation. One monitoring well (well 143) was installed south of the RCP AOC in 1992.

Groundwater samples were analyzed for metals, VOCs, and semivolatile organic compounds during a 1990 sampling episode. Samples from wells JF22 and JF23 were analyzed for organosulfur and explosives-related compounds. None of these compounds was detected, but the results showed some contamination by fluoride in both wells. Cyanide was found in well JF22 at a concentration of $65.6 \mu \mathrm{g} / \mathrm{L}$. The VOC measurements for well JF13 showed the presence of benzene $(1,500 \mu \mathrm{g} / \mathrm{L})$ and methylisobutylketone $(640 \mu \mathrm{g} / \mathrm{L})$. Benzene was also detected at $800 \mu \mathrm{g} / \mathrm{L}$ in well JF13 during a 1992 sampling episode. No volatile organic compounds were detected in the newly installed well (143) (USGS 1992). 


\subsubsection{Potential Pathways of Contaminant Migration}

Existing data indicate that the main pathway of contaminant migration at the RCP $A O C$ is movement through the vadose zone down into the groundwater and then transport by groundwater.

The direction of groundwater movement in the Talbot aquifers appears to be away from the RCP AOC toward the Gunpowder River and Chesapeake Bay. However, the lateral gradients in the lower aquifers are quite small (USGS 1991). Vertical movement of groundwater appears to be down through the aquifers. Offshore, there may be upward flow from each of the three Talbot aquifers into the Gunpowder and Bush rivers. Movement in the surface and confined aquifers is affected by the tides (USGS 1991).

Surface water and associated sediment transport may play some role in contaminant migration in that surface runoff, particularly after intense storms, may carry dissolved and suspended contaminants from the contaminated areas into the river and bay. Lateral contaminant migration by surface water is expected to be minor (Sonntag 1991). However, surface water percolating through and leaching contaminated soils may be a major pathway by which contaminants, especially metals and VOCs, move down into the groundwater. Any contaminants that may have been present in the past in sufficient amounts to exist as free liquid in the soil would be expected to migrate down, independent of the presence of water.

Because of the generally humid conditions in the J-Field study area, wind transport of contaminated soil in areas with a good vegetative cover is expected to be minor. Diffusion of contaminated soil gas into the atmosphere and direct volatilization of contaminants from the soil are also expected to be release mechanisms.

\subsubsection{South Beach Trench}

\subsubsection{Types of Waste Present}

No information is available concerning chemical or hazardous material disposal in the SBT. It is possible that the trench was originally used as a borrow pit to obtain soil for the demolition work on the South Beach of J-Field (Nemeth 1989). A review of aerial photographs reveals the presence of an additional trench, which is now filled in but visible, about $40 \mathrm{ft}$ west of current SBT. In the photographs, the western trench is oriented east-west and is about $300 \mathrm{ft}$ in length. Small drums are scattered in the woods near the western trench (U.S. Army 1965). 


\subsubsection{Types of Contaminants Present}

\section{Soil Gas}

Soil-gas samples have not been collected from this area.

\section{Soil}

Analysis of a single soil sample collected in the SBT area as part of an environmental survey in 1983 (Nemeth 1989) showed a low level of chlordane $(53 \mu \mathrm{g} / \mathrm{kg}$ ) and tentatively identified several other organic compounds. Two soil samples were collected by the USGS in the SBT area (locations 21 and 22 in Figure 2.9). The samples were collected at 1-ft depths and analyzed for indicator parameters, metals, VOCs, semivolatile compounds, and explosives-related compounds (Hughes 1992). The results indicate that metals are present in low concentrations: lead, ranging from 2 to $22 \mathrm{mg} / \mathrm{kg}$; copper, from 7 to $15 \mathrm{mg} / \mathrm{kg}$; and chromium, from 7 to $9 \mathrm{mg} / \mathrm{kg}$. Acetone was the only organic compound detected (ranging from 10 to $25 \mathrm{mg} / \mathrm{kg}$ ).

\section{Surface Water}

Surface water samples have not been collected at the SBT.

\section{Groundwater}

A monitoring well (TH10 in Figure 2.13) was installed south of the trench during the 1977 environmental survey (Nemeth 1989). Water collected from this well was analyzed for extractable organic compounds; analyses showed the presence of hydrocarbons, dimethylnaphthalene, and $\mathrm{N}, \mathrm{N}$-dimethylformamide. This well was also sampled as part of the RFA, with analysis for VOCs, BNAs, pesticides, and PCBs. No contaminants were detected in the water at that time (Nemeth 1989).

The USGS sampled well TH10 in 1991 as part of the hydrological assessment, Phase I. The water was analyzed for metals, water quality parameters, major ions, VOCs, and explosives-related compounds. No contamination was detected. Samples collected in 1992 from wells JF1 and JF2 were analyzed for VOCs. Benzene concentrations ranged from 110 to $800 \mu \mathrm{g} / \mathrm{L}$ in the surficial aquifer. Low levels of acetone were also detected.

\subsubsection{Potential Pathways of Contaminant Migration}

The main pathway of contaminant migration at the South Beach Trench is believed to be movement through the vadose zone into the groundwater and then transport by the groundwater. 
The direction of groundwater movement in the Talbot aquifers appears to be away from the trench area toward the bay. However, the lateral gradients in the lower aquifers are quite small (USGS 1991). The vertical movement of groundwater appears to be down through the aquifers; however, offshore there may be upward flow from each of the three Talbot aquifers into the Gunpowder and Bush rivers. Movement in the surficial and confined aquifers is affected by the tides (USGS 1991).

Surface water and associated sediment transport may play some role in contaminant migration in that surface runoff, particularly after intense storms, may carry dissolved and suspended contaminants from contaminated soil down into the bay. Lateral contaminant migration by surface water is expected to be minor (Sonntag 1991). However, surface water percolating through and leaching contaminated soils may be a major pathway by which contaminants, especially metals and VOCs, move down into the groundwater. Any contaminants that may have been present in the past in sufficient amounts to exist as free liquid in the soil would be expected to migrate down independent of the presence of water.

Because of the generally humid conditions and the presence of a vegetative cover over the South Beach Trench, wind transport of contaminated soil is expected to be minor. Diffusion of contaminated soil gas into the atmosphere and direct volatilization of contaminants from the soil are also expected to be minor.

\subsubsection{South Beach Demolition Ground}

\subsubsection{Types of Waste Present}

The SBDG was used as a demolition site for HE during the 1960s and 1970s. Items were detonated either at the ground surface or buried several feet deep. Because of the high rates of erosion at J-Field, the SBDG is now offshore in the Chesapeake Bay (Hughes 1993). Its presence is marked only by the abundant fragments of munitions and pieces of metal that can be observed at low tide.

\subsubsection{Types of Contaminants Present}

\section{Soil Gas and Soil}

Soil-gas and soil sampling and analysis were not conducted because the area is now offshore. 


\section{Surface Water}

Surface water samples were collected by the USGS in 1991 at low tide close to the SBDG shore (locations 12 and 13 in Figure 2.11). Both filtered and unfiltered samples were analyzed for major water quality parameters, metals, and a few organic compounds. Phenol, TOC, and TOX were detected in the unfiltered sample from location $13(9.6,4,000$, and $30.4 \mu \mathrm{g} / \mathrm{L}$, respectively).

As described in Section 2.3.1.2, the USGS and EPA ERT sampled surface water and sediment from the location of the SBDG. In general, the nearshore surface water data from the samples collected to date show essentially no contamination. What contamination that does exist appears to be associated with the suspended solids. This suggests that the nearshore sediments may be contaminated. Additional data are needed to evaluate the nearshore sediments.

\section{Groundwater}

Groundwater sampling and analysis were not performed because the area is now offshore and no wells are present in the immediate area.

\subsubsection{Potential Pathways of Contaminant Migration}

The main pathway of contaminant migration at the SBDG is expected to be by surface water, including wave action and tidal action. This conclusion is valid only for metals, because organic compounds most likely would have degraded in the bay. Because this area is currently under water, wind transport of contaminants is expected to be an insignificant migration pathway.

\subsubsection{Prototype Building}

\subsubsection{Types of Waste Present}

The PB area was believed to be used primarily for the storage of solid waste when disposal operations were active at J-Field. In addition, a review of aerial photographs suggests that there was a burning area about $200 \mathrm{ft}$ west of the PB and near the edge of the existing tree line. The southern boundary of the area is marked by piles of soil, while its northern edge is marked by tall reeds and shallow ponded water. A rusted drum and scrap metal have been found on the ground surface (U.S. Army 1965). Another suspect burning area is located northeast of the PB. No records were kept of the types or quantities of material stored or potentially burned at the PB. 


\subsubsection{Types of Contaminants Present}

\section{Soil Gas}

Soil-gas sampling and analysis were not performed in this area.

\section{Soil}

As part of the 1986 RFA (Nemeth 1989), surface soil samples collected at several locations near the PB (Figure 2.8) were analyzed for metals, extractable metals, and explosives-related compounds. Composites of samples from different locations were analyzed for BNAs, pesticides, and PCBs.

Cadmium and lead were detected at concentrations of 16.6 and $1,622 \mathrm{mg} / \mathrm{kg}$ (respectively) near the southern side of the PB. Organic compounds were also present in the soil samples, but below measurable levels. A composite sample taken near the PB contained low concentrations of pesticides, including $1.0 \mathrm{mg} / \mathrm{kg}$ each of DDD, DDE, and DDT.

Soil samples were collected by the USGS in 1991 at 36 sites in J-Field, including the PB (locations 11 through 15 in Figure 2.9). The samples were collected at 1-ft depths and analyzed for indicator parameters, metals, VOCs, semivolatile compounds, and explosivesrelated compounds (Hughes 1992). The analyses showed that metals contamination is present at the site, especially at location 15, where lead was detected at $93.3 \mathrm{mg} / \mathrm{kg}$, chromium at $18.8 \mathrm{~m} / \mathrm{kg}$, copper at $47.5 \mathrm{mg} / \mathrm{kg}$, and zinc at $158 \mathrm{mg} / \mathrm{kg}$. Limited analyses for organic compounds were also conducted; no significant contamination was found.

\section{Surface Water}

As noted in Section 2.3.1.2, the USGS and EPA ERT sampled surface water and sediment offshore from the PB.

\section{Groundwater}

Three monitoring wells were installed in the area of the PB (wells TH5, TH6, and TH8 in Figure 2.13). Analysis of a water sample collected from TH5 during an environmental survey (Nemeth 1989) showed only compounds related to well construction. Minor amounts of hydrocarbons were detected in groundwater from TH8. The compounds 111TCE and dimethyl disulfide were detected in well $\mathrm{TH} 6$ (on the southern side of the PB).

An additional monitoring well nest, JF3, was installed near the PB by the USGS (Sonntag 1991; Hughes 1993). The well nest consists of three wells, screened in the confined aquifer, the leaky confined unit, and the surficial aquifer of the Talbot Formation (Figure 2.13). Groundwater samples were analyzed for metals, water quality parameters, 
VOCs, and semivolatile organic compounds. The results of VOC measurements on samples from well TH8 showed that benzene $(6.43 \mu \mathrm{g} / \mathrm{L})$ and methylisobutylketone $(120 \mu \mathrm{g} / \mathrm{L})$ contamination is present. However, no VOCs were detected in well TH8 or in wells JF3-1, JF3-2, and JF3-3 during a 1992 sampling episode (USGS 1992).

\subsubsection{Potential Pathways of Contaminant Migration}

The main pathway of contaminant migration at the PB is believed to be movement through the vadose zone into the groundwater and then transport by the groundwater.

The direction of groundwater movement in the Talbot aquifers appears to be away from the PB toward the Gunpowder River. However, the lateral gradients in the lower aquifers are quite small (USGS 1991). The vertical movement of groundwater appears to be down through the aquifers; however, offshore there may be upward flow from each of the three Talbot aquifers and into the Gunpowder and Bush rivers. Movement in the surface and confined aquifers is affected by the tides (USGS 1991).

Surface water and associated sediment transport may play some role in contaminant migration in that surface runoff, particularly after intense storms, may also carry dissolved and suspended contaminants from the soil toward the river. Lateral contaminant migration by surface water is expected to be minor (Sonntag 1991). However, surface water percolating through and leaching contaminated soils may be a major pathway by which contaminants, especially metals and VOCs, move down into the groundwater. Any contaminants that may have been present in the past in sufficient amounts to exist as free liquid in the soil would be expected to migrate down, independent of the presence of water.

Because of the generally humid conditions in the J-Field study area, wind transport of contaminated soil in areas with a good vegetative cover is expected to be a minor migration pathway. Diffusion of contaminated soil gas into the atmosphere and direct volatilization of contaminants from the soil are also expected to be minor. However, because portions of the PB area are unvegetated or are sparsely covered with stressed vegetation, and because at least part of the area is expected to be used for open burning, the air pathway may be significant.

\subsubsection{Robins Point Tower Site}

\subsubsection{Types of Waste Present}

Robins Point was a launch and observation site for rocket testing programs conducted in the J-Field area. No information has been uncovered to indicate that solid or hazardous waste was generated or handled at this site. However, Nemeth (1989) found records indicating that radioactive contaminated wood may have been burned at this site. 


\subsubsection{Types of Contaminants Present}

\section{Soil Gas}

Soil-gas sampling and analysis were not conducted in this area.

\section{Soil}

Field inspection of this site found no visual evidence of soil contamination. Because no information exists that waste was ever handled in this area, soil sampling and analysis were not conducted. No radiation above normal background levels was detected in a field radiation survey conducted during February 1988 (Nemeth 1989).

\section{Surface Water}

As noted in Section 2.3.1.2, the USGS and the EPA ERT sampled surface water and sediment offshore from the RPTS.

\section{Groundwater}

Groundwater samples from monitoring well TH11 (Figure 2.13) were analyzed for extractable organic compounds. Results indicated very low levels of triethylchlorobenzene and TCLEE. As part of the 1986 RFA, the well was resampled for VOCs, BNAs, pesticides, and PCBs. No contaminants were detected.

An additional monitoring well (JF1) was installed near the tower by the USGS as part of their hydrological assessment (Sonntag 1991; Hughes 1993). The well is screened in the Potomac Group (Figure 2.13). Groundwater samples were analyzed for metals, water quality parameters, VOCs, and semivolatile organic compounds. Data for well JF1 showed low levels of VOC contamination (2.25 $\mathrm{gg} / \mathrm{L} 111 \mathrm{TCE}$ at a depth of 185-190 ft). However, this finding must be taken as provisional, because one of the two quality control water blanks also showed contamination with TCLEA, TCLEE, and TRCLE (USGS 1992). For the sake of comparison, an upgradient well (JF2) of similar depth, located at the J-Field gate entrance also had detectable concentrations of TRCLE during the same sampling episode. Acetone and 1,1-dichloroethane were detected at concentration of 4 and $1 \mu \mathrm{g} / \mathrm{L}$, respectively in a 1992 sampling event (USGS 1992).

\subsubsection{Potential Pathways of Contaminant Migration}

No information is available to verify that solid or hazardous waste was generated or handled at this site. A test burn of radioactive contaminated wood may have occurred-at the 
site; however, the limited sampling conducted to date indicates that this area is not a source of contamination. Thus there are no potential pathways for contaminant migration.

\subsubsection{Robins Point Demolition Ground}

\subsubsection{Types of Waste Present}

The inactive portion of the RPDG was used primarily for demolition of explosive materials. Small amounts of sensitive and unstable chemicals were occasionally destroyed at the area. A portion of the RPDG is still used for emergency disposal operations.

\subsubsection{Types of Contaminants Present}

\section{Soil Gas}

Soil-gas sampling and analysis were not conducted in this area.

\section{Soil}

Surface soil collected during the 1986 RFA was analyzed for metals, explosivesrelated compounds, and organic compounds. The analyses did not detect any contamination in the RPDG (Nemeth 1989).

Soil samples were collected by the USGS at 36 sites at J-Field, including the RPDG (locations 37 through 41 in Figure 2.9). The samples, collected at 1-ft depths, were analyzed for indicator parameters, metals, VOCs, semivolatile organic compounds, and explosives (Hughes 1992). The results indicated the presence of metals in low concentrations, including lead, up to $20.3 \mathrm{mg} / \mathrm{kg}$ at location 38 ; chromium, up to $16.3 \mathrm{mg} / \mathrm{kg}$ at location 37 ; copper, up to $75.5 \mathrm{mg} / \mathrm{kg}$ at location 37 ; and zinc, up to $22.8 \mathrm{mg} / \mathrm{kg}$ at location 39 . Limited analyses for organic compounds were also conducted; no significant contamination was found.

\section{Surface Water}

Laboratory analyses of standing water conducted during the 1986 RFA did not detect any contamination by metals, explosives, or organic compounds (Nemeth 1989).

\section{Groundwater}

Two monitoring wells were installed in the active portion of the RPDG in 1992 and will be sampled as a part of the RI. However, groundwater contamination is not expected 
given the short period of time the site was used, the nature of the operations, and the absence of soil and surface water contamination.

\subsubsection{Potential Pathways of Contaminant Migration}

Given the nature of the operations at the site and the absence of soil and surface water contamination, it is doubtful that any contamination still exists at this site. However, surface water that ponds west of a berm separating the active from the inactive portion of the RPDG seeps through the berm and discharges into the inactive portion of the site. As a result, surface water may play some role in contaminant migration in that surface runoff may carry dissolved and suspended contaminants from the active portion of the site into the inactive portion. 


\section{WORK PLAN RATIONALE}

\subsection{DATA NEEDS}

Because of the paucity of existing data and the history of activities at J-Field, additional information is needed to adequately characterize the AOCs and PAOCs. Data needs include information on the environmental setting of J-Field, on the nature and extent of contamination in environmental media, on potential migration pathways and potential human and environmental receptors, and on the operational history of each AOC.

Because a Focused Feasibility Study (FFS) is being conducted at the TBP (Work Plan for the FFS of the Toxic Burning Pits Area), data collection activities associated with the TBP will be placed on an accelerated schedule.

\subsubsection{Unexploded Ordnance and Chemical Warfare Agents}

Before field activities are initiated, the areas around each AOC will be thoroughly inspected for the possible presence of unexploded ordnance (UXO) and CWAs. The inspections will be sufficiently extensive to cover areas (including marshes and nearshore locations) from which samples will be collected and areas that might be used to stage sampling activities or to conduct future remediation activities.

The inspections will include a walkover to detect surface objects, including UXO and CWA containers, and geophysical surveys to detect buried UXO and CWA containers. In any areas where data needs necessitate making soil borings or installing additional monitoring wells, the initial surveys will be carried out to determine the presence of dangerous items to the maximum depths that would be sampled by the borings or wells. Areas that will have been surveyed by Weston (1992) probably will not need to be resurveyed.

Surveys of the SBDG, which is now offshore (Hughes 1993), are needed to show the extent of the area used for munitions disposal. The survey techniques selected will be appropriate for the offshore location of the site. For example, surveys will be carried out at low tide when metal fragments can be observed.

Any item located by either walkover or geophysical surveys will be precisely marked on a map. If possible, all located items will be excavated and disposed of appropriately.

The Weston work plan (1992) shows the presence of several drums around the TBP, WPP, and RCP AOCs. These drums will be inspected, the contents analyzed if necessary, and the drums and contents disposed of by appropriate procedures. 
Appropriate health and safety procedures, as required by the U.S. Army, ${ }^{1}$ will be implemented during all surveys (whether walkover or geophysical), all excavations and removals, and all drum survey and management activities. Because of the potential presence of UXO and CWA-contaminated items and the potential presence of CWA-contaminated soils and sediments, especially in the marshes and estuaries (USGS 1991), bubble tests and any other appropriate tests will be conducted to determine the degree of CWA contamination of all discovered debris and potentially dangerous items.

In addition to the surveys of the AOCs, at least a walkover survey of all the rest of J-Field will be considered because of the extremely dangerous CWAs and explosive materials disposed of at J-Field and the lack of detailed disposal records. In addition, such a survey would be needed if, at the conclusion of the RI/FS process, all of J-Field were placed under RCRA, with only one open burning and two open detonation areas remaining in use under interim status.

Even if an area "passes" a UXO/CWA survey, U.S. Army protocol specifies that investigators must assume any soil/sediment/debris sample to be CWA-contaminated and to be handled accordingly. The more salient aspects of this protocol are as follows:

- Suspect CWA-contaminated items can only leave the APG under escort by the APG Technical Escort Unit,

- Suspect CWA-contaminated items be must analyzed for CWA by both gross and sensitive screens before the release of the item for laboratory analysis of the more conventional contaminants, and

- Samples containing CWAs cannot be released for the laboratory analysis of the more conventional contaminants.

APG has established an on-site contractor laboratory capable of performing the necessary gross and sensitive CWA screens. As a result, it is possible to use the on-site laboratory to certify that samples, or locations from which samples are collected, are CWA free. These screens are needed for soil and sediment samples, but not for water samples because CWAs degrade quickly in water.

\subsubsection{Sampling Approach}

Because of the nature of the contaminants, the current and historical use of the site for open burning and open detonation of UXO and CWAs, and the amount of sampling and analysis that may be required to characterize each AOC, Argonne National Laboratory (ANL) proposes to use a mobile field laboratory to conduct sample screening and initial analysis. This screening will be needed from a health and safety standpoint to determine if samples are contaminated with CWAs. Field screening for the more conventional contaminants of

1 Some of these procedures are outlined in Weston (1992). 
concern will assist ANL in focusing subsequent laboratory sampling/analyses activities. Procedures for carrying out field screening for CWAs and other conventional contaminants will be detailed in the FSP. The FSP will include three stages, as described below.

\subsubsection{Stage I}

In Stage I of the three-stage sampling approach, soil and sediment samples analyzed on-site will be limited to EPA analytical level I and II analyses. Additional details are given in Section 3.2 of the FSP. A subset of the soil and sediment samples will be, analyzed on-site, and surface water and groundwater samples collected during Stage I will be sent off-site for analysis at EPA levels III and IV. This action is possible because of the relatively rapid breakdown of CWAs in water and because a subset of the soil and sediment samples to be collected are expected to be free from CWAs.

Stage I soil/sediment sampling activities are designed so that the results, combined with existing data, can be used to determine locations and depths free from CWAs or UXO and to choose sampling locations for off-site Contract Laboratory Program (CLP) analyses. In addition, these activities can be used to help determine the nature and extent of contamination sources. Stage I soil/sediment activities may require several rounds or phases of sampling in which the area sampled is progressively extended until sampling shows little or no contamination. The Stage I soil/sediment sampling stops with this last phase as both the lateral extent and depth of the contaminated region are delineated by the results of this and previous rounds of Stage I sampling. The Stage I phasing is potentially applicable to sampling activities for soil, sediment, and soil gas. The existing soil-gas data, which show soil-gas contamination out to the edge of the areas surveyed, exemplify the need for this use of phasing.

\subsubsection{Stage II}

The goal of Stage II activities for soil and sediment sampling is characterization of contamination within the areas delineated by the phases of Stage I sampling (and/or verification that apparently uncontaminated areas are "clean") to the extent needed to carry out human health and ecological risk analyses. Both the analytes and the choice of sampling locations will be based on the Stage I results. At this time, it is assumed that analytical methods will include off-site analyses of soils and sediments with CLP and AEC methods yielding data of EPA analytical levels III, IV, or V.

Stage II sampling activities for soil, sediment, surface water, and groundwater will consist of collecting additional samples of environmental media and collecting additional samples from existing wells. Stage I results will be used to determine the location and number of additional samples and additional monitoring wells (if any) and any changes in the analytical suites. The groundwater, soil, and sediment samples for Stage II will be analyzed off-site to provide EPA level III, IV, or V data. These data will be combined with the Stage I data to determine the extent of areas of contaminated surface water or of plumes 
of contaminated groundwater, to determine the extent of contaminated soil and sediment, and to characterize the contamination within those areas or plumes.

\subsubsection{Stage III}

In Stage III, sampling and analyses strategies will be developed, if necessary, to ensure that the desired DQOs for remedial alternative selection have been achieved.

Essentially no background samples will be collected in any of the stages. Instead, data collected by APG as part of a sitewide background study and other background data collected by APG contractors will be used.

\subsection{DATA QUALITY OBJECTIVES}

DQOs are developed to ensure that the data collected are sufficient and of adequate quality for remedial response activities. Initial evaluation indicates that additional data will have to be collected to adequately characterize the site, conduct risk assessment, and evaluate remedial alternatives. The elements needed to meet these project objectives are as follows:

1. Identify the objectives of collecting data;

2. Specify the type of data needed;

3. Define data users;

4. Identify data quality needs;

5. Identify data quantity needs;

6. Identify the analytical method for sample analysis; and

7. Review precision, accuracy, representativeness, completeness, and comparability (PARCC) parameters.

\subsubsection{Site Characterization}

\subsubsection{Objectives for Data Collection}

The objectives of additional sampling and analysis for site characterization are to collect sufficient information to characterize each AOC and PAOC to the extent needed to assess risk and evaluate remedial alternatives. During site characterization, conceptual models will be developed for each site to describe suspected sources of contamination, types 
and concentrations of contamination, affected media, the rate and route of contaminant migration, and potential impact of contaminants on sensitive receptors.

Additional data are needed to determine the nature and extent of contamination in the areas of the TBP, WPP, and RCP AOCs. In the SBDG, groundwater flow into the adjacent Chesapeake Bay and beach erosion are considered to be the important contaminant migration pathways. In that area, additional data are required to address the presence of any significant residual contamination by heavy metals or explosives.

\subsubsection{Specification of Data Type and Contamination}

Measurements of contaminant concentrations in affected media are needed to characterize potential chemical contamination and to determine the relative significance of different pathways of contaminant migration. Because of the nature and historical use of J-Field, a UXO survey should be conducted to identify the activity areas. Any UXO encountered that might contain a military CWA or that is extremely hazardous will be identified. Surface debris found during the UXO survey will be handled by the Technical Escort Unit through normal APG procedures.

In the near future, the APG Directorate of Safety, Health, and Environment (DSHE) is expected to establish an APG-wide "background baseline" for biota and all environmental media. ANL will use such baseline information as a frame of reference in evaluating contamination levels in all environmental media sampled. Alternatively, ANL will develop J-Field study area background information. In the areas around the TBP, WPP, and RCP AOCs, surface soils will be sampled to determine the sources and types of contamination. In the areas around the TBP, PB, and SBT, additional measurements of subsurface soil will be used to confirm the presence and extent of such contaminants as explosives and pesticides. At several locations in marshes near the TBP, WPP, and RCP, sampling and analyses are needed to determine the nature and extent of any contamination of sediments in the marshes. In concert with the APG/EPA sediment study (see Section 4.2), sediment samples may also be needed from some nearby offshore locations around the WPP and the SBDG to determine if metals, VOCs, explosives, and semivolatile compounds are present.

Sampling and analysis of groundwater in each contaminated site are required to identify the extent of groundwater contamination with VOCs and other chemicals. In the areas around the TBP, WPP, and RCP AOCs, sampling and analysis of any standing surface water will be used to determine contaminant mass flux from these areas to the adjacent marshes, Gunpowder River, and Chesapeake Bay.

\subsubsection{Application of Data}

Data obtained during the RI will be used to develop conceptual models for each AOC at J-Field. The conceptual models will be used to determine several relevant site aspects:

1. Environmental impacts of contamination on aquatic life in the marshes and estuaries at J-Field, 
2. Health impacts on site workers at J-Field,

3. Operable units for RI/FS activities at J-Field, and

4. Cleanup levels for each environmental medium at each site.

\subsubsection{Methods and Quantitation Limits for Sample Analysis}

During the development of site-specific DQOs, available analytical methods will be evaluated relative to any limitations and special considerations that could affect data quality. Analytical factors that will be evaluated on the basis of statistical and sampling considerations are discussed in the FSP. Analytical methods and their quantitation limits are listed in tables in Appendix C for TCL VOCs (Table C.1), TCL semivolatile organic compounds (Table C.2), and TCL pesticides/PCBs (Table C.3). Other tables in Appendix C list the analytical methods and quantitation limits for TAL metals (Table C.4), for principal degradation products of selected CWAs in soil/sediment and water (Table C.5), and for selected explosives and related compounds in soil/sediment and water (Table C.6).

\subsubsection{Identification and Review of Data Quality}

Five parameters (the PARCC parameters) are usually used as data quality indicators to evaluate the adequacy of measurements (EPA 1987). These parameters are summarized as follows:

- Precision - Precision is a quantitative measure of the variability of repeated measurements of the same parameters that are always expressed as standard deviation, relative standard deviation, range, and relative range. The overall precision of measurement data is a mixture of sampling and analytical factors. Analytical precision is easier to control and quantify than site-specific sampling precision.

- Accuracy - Accuracy measures the bias in a measurement system and is usually expressed as percent recovery or percent bias. Percent recovery indicates the accuracy of measurement, while percent bias reports the difference of the result from the true value. Sources of error can be introduced through the sampling process and analysis technique.

- Representativeness - Representativeness expresses the degree to which the measurements accurately and precisely represent the characteristic of the sampling medium or the environmental condition. Representativeness is a quantitative parameter for which the criterion can be best satisfied through proper selection of sampling locations and collection of a sufficient number of samples. 
- Completeness - Completeness is a measure of the amount of information that must be collected during the field investigation to successfully achieve the objectives. A sufficient amount of valid data must be generated to approach valid conclusions.

- Comparability - Comparability is a quantitative parameter expressing the confidence with which one data set can be compared with another. Comparability of data is dependent upon the accuracy and precision of the analytical analysis and proper qualification of data. Only when the precision and accuracy are known can data sets be compared with confidence.

In an ideal situation, analytical methods with appropriate numerical precision and accuracy will be selected for sample analysis. However, as noted in Section 3.1.2, ANL expects to use some field screening and measurement techniques to help "drive" the investigation. The precision and accuracy of this field measurement is not high, but the sample design developed from the field screening and measurement effort can assist ANL in characterizing the environmental conditions at J-Field. Sampling and analysis of several surface and subsurface soils from locations identified by the field measurement effort can representatively characterize the potential contamination and the possible pathways of contaminant migration. However, it should be noted that sampling from offshore sites and some secured and otherwise hazardous areas will make it difficult to complete data collection.

\subsubsection{Risk Assessment Needs}

Available historical information and results from preliminary site investigations indicate the presence of contaminants at levels potentially attributable to past use of the site. Contaminants include those arising from the disposal of solvents, CWAs, and related waste and (to a lesser extent) those generated from the testing of munitions and CWAs. A risk assessment will be conducted to determine if site contaminant levels pose any adverse threats to human health and the environment. The results of this assessment will guide decisions on the need for any remediation effort for the site. Section 3.2.2.1 discusses the rationale and approach for the human health component of the risk assessment and summarizes the types of data needed to implement the assessment. Section 3.2.2.2 discusses the approach, rationale, and data needs to determine potential environmental or ecological consequences.

\subsubsection{Human Health Component}

In general, the risk assessment would follow the methodology presented in the EPA guidance for human health risk assessments (EPA 1989, 1991a,b). The EPA has provided procedures for identifying site contaminants of concern, estimating potential intake of contaminants at the exposure point by potential receptors, estimating toxicity to the potential receptors posed by the contaminant intake amounts, and characterizing the associated risks posed by these contaminants. The risk assessment effort within EPA's RI/FS framework is 
typically a two-component process. As part of RI activities, an assessment would be conducted to establish the baseline risk to human health if no remedial action was undertaken. Potential risks stemming from both current land use and hypothetical future land use are evaluated. This evaluation is commonly referred to as a baseline risk assessment (BRA) and is considered to serve as the no-action alternative. The methodology for the BRA to be conducted at J-Field is described in a document containing the general technical plan for conducting risk assessments at the APG site areas (Durda et al. 1992). The results of the BRA are also intended to be used as a baseline for comparing the protectiveness of cleanup alternatives in the FS relative to potential human health impacts. Uncertainties are inherent in the various steps of the risk assessment process. Consequently, minimization of these uncertainties would be incorporated into the objectives and design of sampling activities to be carried out at J-Field. Documentation requirements aiding the identification and definition of these uncertainties would also be included. The DQOs developed to track activities necessary to obtain the requisite data and information for the performance of a human health risk assessment are illustrated in Figure 3.1. The various steps included in Figure 3.1 are discussed below.

Contaminants of potential concern were initially identified on the basis of a review of available historical information and results from preliminary site investigations. These contaminants are listed in Section 3.4.2, Tables 3.7 and 3.8.

To confirm the presence of site contaminants of concern and to determine any adverse effects to human health associated with site contaminant levels, sampling will be performed during the RI phase to further characterize the nature and extent (including concentrations) of site contaminants and to obtain other data as necessary.

Selection of media to be sampled and sampling locations will be guided by the assumptions regarding preliminary potential pathways of contaminant migration discussed in Section 2.3. These pathways were developed on the basis of currently available information (e.g., historical) on the potential sources of contamination, environmental transport and release mechanisms (media and pathway), and potential receptors. Current land use patterns at J-Field indicate the need to sample various environmental media (including soil, groundwater, surface water, and sediment) and possibly to determine contaminant concentrations in biota (e.g., fish and game) through sampling and/or modeling. In addition, air and groundwater monitoring or modeling may also be needed for future land use estimates.

To ensure that enough information is gathered to allow for a quantitative risk assessment with known confidence, the sampling effort will be designed to provide a sufficient quantity of environmental data and background monitoring data for all affected media. The sampling will be designed to identify the nature and extent (including concentrations and boundaries) of contamination. Quantitative risk assessment also requires that the data obtained be of known quality, meeting quality assurance/quality control (QA/QC) requirements documented in the Quality Assurance Project Plan (QAPJP). 
Problem

Statement

Historical information indicates the presence of contaminant levels attributable to past use of the site

\section{Question to \\ be Answered}

Is risk to human health posed

by site contaminant levels?

Data Needs

Problem

Domain

Logic

Statement

Uncertainty

Constraints

Sampling

and Analysis

Design

- Nature and extent of contamination

- Background data

- Environmental fate and transport information

- Land use information (current and future)

- Toxicity data

- Identification of site contaminants of concern

- Exposure assessment for current and future land use - defining exposure pathways

- identifying potentially exposed receptor or receptor groups (populations)

- estimating the magnitude, duration and frequency of exposure for each receptor or population

- Toxicity assessment

- Risk characterization

- If risk estimates are below remediation goals (e.g., 10-6), the no-action alternative may be considered

- If risk estimates are greater than remediation goals, evaluate remedial alternatives

FIGURE 3.1 Data Quality Objectives for Human Health Risk

Assessment

- Representativeness of measured contaminant mean concentrations for the exposure area

- Adequacy of exposure pathway identification and characterization

- Adequacy of characterizing transport and transformation of contaminants in the environment

- Ability to identify, select, and develop toxicity measures needed in risk characterization

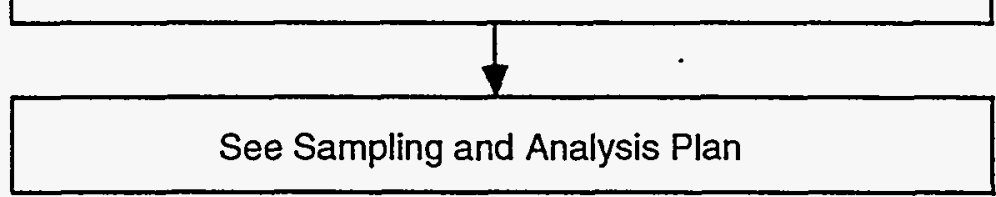


Furthermore, these data will be acquired by analysis methods with sensitivities that allow for comparison of site contaminant levels to background levels (as appropriate) and to regulatory or health advisory levels. This sampling effort will also be designed to (1) provide representative data for exposure areas identified for the site (on the basis of further refinement of the conceptual model with additional data as acquired), (2) address hot spots, (3) evaluate the transport of contaminants of potential concern, and (4) facilitate the final identification of all exposure pathways. Details on this sampling scheme are provided in the FSP.

The set of contaminants quantitatively evaluated in the BRA would be identified on the basis of acquired data and evaluation procedures recommended by the EPA (1989). Exposure point concentrations, which are defined as the contaminant concentration at the point of receptor contact, will be derived from the mean contaminant concentration at a defined area of exposure. These mean concentrations will be used to evaluate exposure to a receptor considered to be representative of an average case. The EPA also recommends that exposure to a reasonably maximally exposed (RME) receptor be estimated. The upper 95th percentile confidence limits of the mean concentrations for each contaminant are used as the exposure point concentrations in deriving intakes by the RME receptor. Land use information will be used to define the remaining exposure parameters (e.g., exposure frequencies and exposure duration) necessary to derive the intake by potential receptors.

Toxicity values used in risk assessments are defined by the EPA as a numerical expression of a substance's dose-response relationship. The EPA provides substance and route-specific reference doses (RfDs) and cancer slope factors in the Integrated Risk Information System (IRIS) database. The toxicity values obtained from IRIS or other EPArecommended sources (e.g., Health Effects Assessment Summary Tables [HEAST]) will be used to quantify the risk associated with contaminant levels for each potential pathway and receptor. For potential contaminants of concern for which toxicity values are not included in IRIS or HEAST, toxicity values will be identified or derived with methods recommended by the EPA. If all efforts fail to identify a toxicity value for a given contaminant, a qualitative evaluation will be provided. RfDs are typically used by the EPA to indicate potential for noncarcinogenic toxicity in an individual. For carcinogens, risks are estimated as the incremental probability of an individual's developing cancer over a lifetime as a result of exposure to the potential carcinogen (i.e., incremental or excess individual lifetime cancer risk).

The risk estimates from the BRA will be compared with the target risk range of $10^{-6}$ to $10^{-4}$ excess incidents of cancer for chemicals that are known or suspected carcinogens. The $10^{-6}$ risk level is often used as the point of departure for determining remediation goals for alternatives when ARARs are not available or are not sufficiently protective because of the presence of multiple contaminants at a site or multiple pathways of exposure. For systemic toxicants (noncarcinogenic contaminants), acceptable exposure levels are those that represent concentration levels to which the human population, including sensitive subgroups, may be exposed without adverse effect during a lifetime or part of a lifetime. This level is measured 
by the EPA in terms of a hazard index. A hazard index of 1 or greater indicates a potential for adverse noncarcinogenic effects.

Uncertainties inherent in the risk assessment process are quantitatively evaluated and summarized; information on uncertainty arising from the various steps of the process is included in the calculations. Potential sources of uncertainty are explicitly identified and evaluated so that uncertainties can be minimized through an efficient sampling design. The sampling will be designed so that the analytical data acquired will be adequate to fully characterize exposure pathways in light of factors such as heterogeneity of the environmental medium and identification of hot spots. The sampling effort will also aim to adequately characterize transport and transformation of chemicals in the environment.

In summary, the sampling and analysis regime to be undertaken for J-Field will be designed to produce data of known quality for the purposes of determining the nature and extent of contamination, determining the spatial and temporal variability, and allowing for the interpretation of the observed values through comparison with background levels or regulatory benchmarks. Ultimately, data gathered from the sampling effort are intended to identify critical areas of exposure so that appropriate remediation of these areas can be undertaken.

\subsubsection{Ecological Component}

In addition to protecting human health, the CERCLA process requires the EPA to protect the natural environment with respect to releases or potential releases of contaminants from hazardous waste sites. Remedial actions must be protective of ecological systems and must include some form of ecological assessment. Accordingly, an ecological risk assessment (ERA) will be conducted to identify any pathways of contaminant transport in terrestrial, wetland, and estuarine systems on and adjacent to J-Field and to determine if existing contaminants pose an ecological threat. The results of the ERA will help determine the appropriate remedial action, if necessary. A separate ERA Work Plan has been drafted for the ERA and has been reviewed by EPA Region III. The plan describes the ERA objectives, work tasks, specific QA procedures, and level of effort required for environmental site characterization (e.g., sample locations and number and types of samples to be collected).

Because of the uncertainties about the extent and ecological impacts of the J-Field contamination, a phased approach has been adopted for the ERA (Figure 3.2). The phased approach is based on the need to establish an environmental baseline for the assessment of ecological risks and the fact that little is known about the impacts to ecological systems from certain types of contaminants at APG. The study will evaluate each AOC individually, in three phases. Results of the study will be integrated to evaluate the J-Field site as a whole. Modifications to the types of work conducted under each phase will depend on the results of studies conducted in the previous phase. 


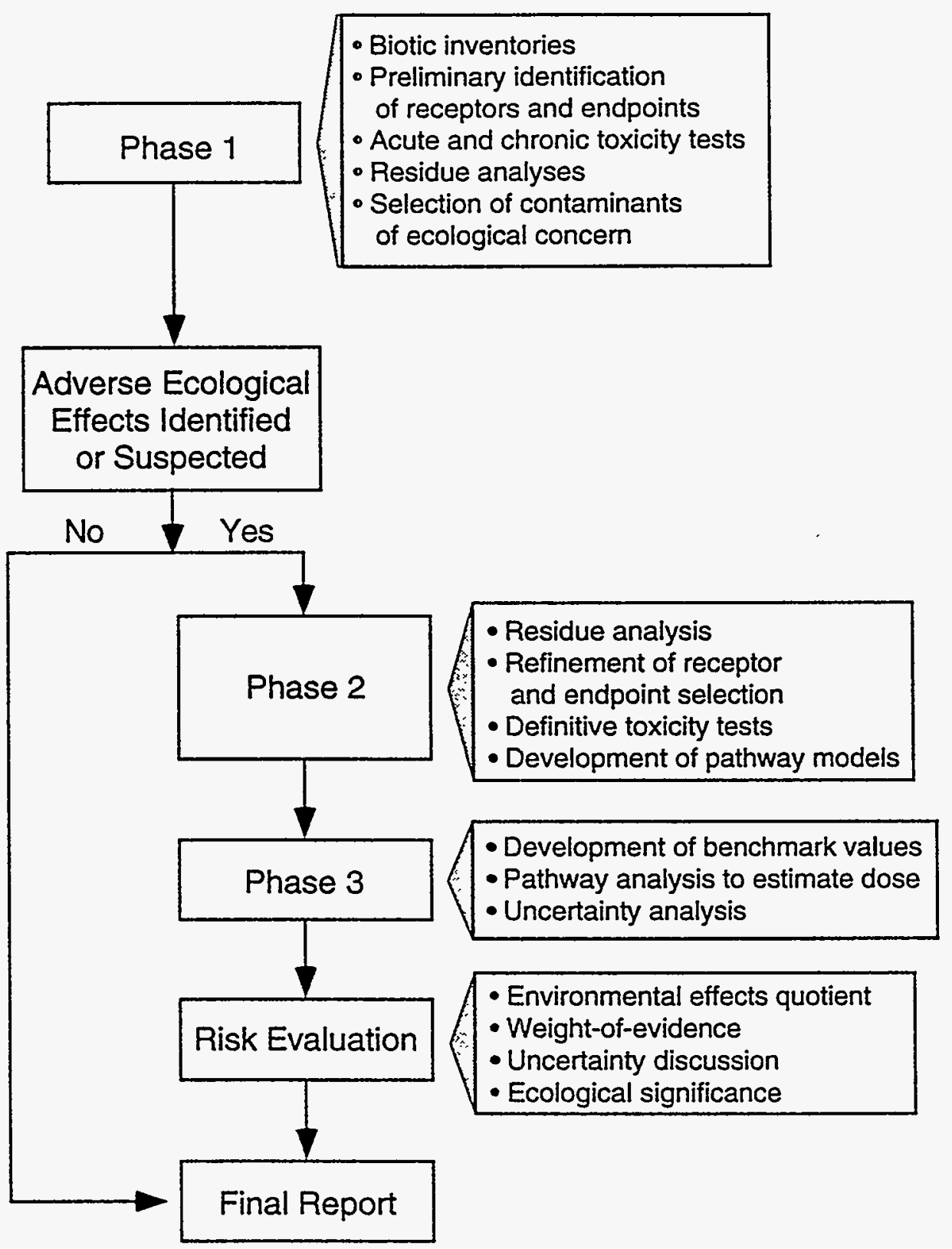

FIGURE 3.2 Phased Approach Proposed for J-Field Ecological Risk Assessment 
Phase 1 of the ERA will determine (1) whether ecological effects from contamination are evident (on the basis of the distribution and abundance of biota) and (2) whether the media from the primary areas of contamination at the J-Field sites are toxic to biota. In addition, population estimates for biota and residual analysis of organisms collected during the biotic survey will be an important part of the pathway analyses to take place during Phase 3. Biological surveys will include contaminated areas of J-Field, as well as one or more reference sites with ecological characteristics comparable to contaminated habitats at J-Field. Contaminated areas will be identified by an on-site analytical suite, which will measure major classes of chemicals, and by rapid toxicity screening (e.g., the MicroTox or Daphnia Q tests). Toxicity screening will occur as part of the physical media sampling.

Phase 2 will consist primarily of in-situ and laboratory toxicity testing to determine which organisms are affected by contaminated environmental media and to assess the magnitude of the effect and extent of the contamination. This phase of toxicity testing will occur after completion of the off-site analytical suite, which will measure the concentration of individual elements and chemicals. Final selection of appropriate receptors and endpoints for Phase 3 pathway analysis and risk assessment will be made, and a pathway model will be finalized.

Phase 3 will consist of pathway analysis and other risk assessment procedures appropriate to the nature of the effects determined in Phases 1 and 2. A probabilistic approach is planned in order to evaluate uncertainty.

\subsubsection{Remedial Alternative Evaluation}

Remedial alternatives are developed to provide decision makers an appropriate range of options and sufficient information to adequately compare each alternative with respect to the evaluation criteria and to select appropriate remediation for site conditions. Generally, remedial action technologies are assembled (with respect to the media to which they would be applied) into alternatives that address contamination on a sitewide basis for an identified operable unit. To reduce the number of alternatives to be analyzed in detail, it is proposed by the EPA (1988a) that assembled alternatives be defined and screened to remove technology types that are not technically implementable for a specific medium and site. The alternatives judged to be the best or the most promising will be retained for further consideration and analysis.

The quality objectives for the data used to evaluate remedial alternatives are discussed in the following sections on the basis of criteria proposed by EPA (1988a).

\subsubsection{Development of Remedial Action Objectives}

Remedial action objectives are developed to protect human health and the environment. For protection of human health, the cleanup level for each contaminant of concern and medium at each site can be determined by site-specific modeling. The acceptable 
exposure levels can be determined from the results of the BRA. In addition, the expected exposures and associated risk for each alternative must be evaluated. For protection of the environment, specific cleanup levels for each site must be determined on the basis of criteria for protection of wildlife living in the J-Field area. In this case, the wildlife to be protected includes terrestrial species and aquatic species in the marshes and estuaries.

The ongoing release of contaminants from the various sources at J-Field might affect the contaminant levels in other media (e.g., groundwater). For instance, leaching and migration of contaminants from soils in the TBP to groundwater, followed by transport and discharge of contaminated groundwater into the estuaries or marshes, would affect the contaminant concentration in marshes or estuaries. Therefore, the effect of source control actions on the remediation levels or time frames for other media should be evaluated.

\subsubsection{Assembly of Candidate Altermatives}

Remedial action alternatives are developed from remedial action technologies that are applicable to contaminated environmental media at the site or operable unit and that contribute to satisfaction of the remedial action objectives. The appropriateness of separating contaminated sites into several operable units has to be determined by considering the possible opportunity to undertake a limited action to achieve significant risk reduction quickly. For example, the TBP AOC has been singled out as an operable unit because the apparent nature and extent of contamination at this area indicates the need for expedited action. This expedited action will be facilitated by the FFS. Areas at J-Field that can be considered as operable units are the TBP, the remaining two burning areas (the WPP and RCP), the two demolition areas (the RPDG and the SBDG), and the PB. In addition, depending upon the results of the RI and the FFS, groundwater may be proposed as an operable unit. Further characterization is needed at the remaining AOCs and PAOCs before they can be designated contaminant sources or be removed from the list of AOCs to be remediated.

Many types of remedial actions are candidates for use at J-Field. For contaminated soil, these candidate measures include institutional actions, containment actions, in-situ treatment, or excavation followed by treatment or disposal. Institutional actions include the use of fencing, imposition of deed restrictions, and installation of monitoring wells. Containment actions include the use of caps or the installation of vertical or horizontal barriers. Treatment technologies include solidification/fixation; dewatering; and physical, chemical, biological, and high-temperature technologies. For groundwater, remedial actions include institutional and containment actions similar to those for soils, in-situ treatment, and pump-and-treat and discharge actions. Treatment technologies include physical, chemical, and biological technologies. Discharge options include disposal to surface water and reinjection to the groundwater.

The types of remedial actions available can be combined to identify remedial action alternatives for J-Field. Individual process options belonging to each technology type must be screened relative to effectiveness, feasibility (implementability), and cost. Technology 
types that are not technically feasible for a specific media and site or operable unit or that are not compatible with the continued use of J-Field as an OB/OD area will be excluded. Individual process options that are not effective, not feasible, or too costly will also be screened out.

\subsubsection{Evaluation of Alternatives}

Assembled candidate alternatives will be evaluated against the short-term and longterm aspects of three broad criteria: effectiveness, implementability, and cost (EPA 1988). Short term refers to the period of construction and the implementation of the remedial action; long term refers to the period after completion of the remedial action. During screening of alternatives, each specific technology or process option will be evaluated primarily on the basis of whether it can meet a particular remedial action objective. In this phase, similar alternatives will be compared and the most promising alternatives will be carried forward for detailed analysis. During the detailed analysis phase of the process, the alternatives will be evaluated against nine specific criteria and their individual factors. Table 3.1 summarizes the threshold and primary balancing factors to be considered during the detailed analysis. The relationship between the screening criteria and the nine evaluation criteria is conceptually illustrated in Figure 3.3.

The RI/FS for J-Field addresses only contamination within the peninsula. Contamination in the estuaries and Chesapeake Bay are beyond the scope of this study. Application of the three criteria (effectiveness, implementability, and cost) to J-Field for alternative screening and evaluation is discussed below. These criteria will also be addressed in the FS.

\section{Effectiveness Evaluation}

For each alternative, the effectiveness criterion is applied to evaluate the degree of protection of human health and the environment. In this evaluation, changes of one or more characteristics of the contaminated media - toxicity, mobility, or volume - by the use of treatment processes should be considered. In addition, decreases in the inherent threats or risks associated with the hazardous materials have to be included for evaluation.

For contaminated soils at J-Field, for example, a candidate alternative consists of excavating the contaminated soils from the different sites, combining the soils at one selected location (either on-site or off-site), and capping the pile. This alternative has the advantage of reducing the size of the contaminated area and reducing the impact of percolating leachate by selection of an appropriate location for the pile. The possibility of applying treatment technologies to immobilize or remove contaminants from contaminated soils should be analyzed in the FS. The applicability of removal of organic contaminants from contaminated soils by high-temperature treatment technologies should be evaluated. 
TABLE 3.1 Threshold and Primary Balancing Factors to Consider in Detailed Evaluation of Selected J-Field Alternatives against Criteria

\begin{tabular}{|c|c|c|c|c|c|c|}
\hline $\begin{array}{l}\text { Overall Protection } \\
\text { of Human Health and } \\
\text { the Environment }\end{array}$ & $\begin{array}{l}\text { Compliance } \\
\text { with ARARs }\end{array}$ & $\begin{array}{c}\text { Long-Term } \\
\text { Effectiveness } \\
\text { and Permanence }\end{array}$ & $\begin{array}{l}\text { Reduction of } \\
\text { Toxicity, Mobility, } \\
\text { and Volume by } \\
\text { Treatment }\end{array}$ & $\begin{array}{c}\text { Short-Term } \\
\text { Effectiveness }^{\mathrm{a}}\end{array}$ & Implementability & Cost \\
\hline $\begin{array}{l}\text { How alternative } \\
\text { provides protection of } \\
\text { human health } \\
\text { How alternative } \\
\text { provides protection of } \\
\text { the environment }\end{array}$ & $\begin{array}{l}\text { Compliance } \\
\text { with action- } \\
\text { specific ARARs } \\
\text { Compliance } \\
\text { with chemical- } \\
\text { specific ARARs } \\
\text { Compliance } \\
\text { with location- } \\
\text { specific ARARs } \\
\text { Compliance } \\
\text { with other } \\
\text { criteria and } \\
\text { "to-be- } \\
\text { considereds" }\end{array}$ & $\begin{array}{l}\text { Magnitude of } \\
\text { residual risk } \\
\text { Adequacy and } \\
\text { reliability of } \\
\text { controls }\end{array}$ & $\begin{array}{l}\text { Treatment process } \\
\text { used } \\
\text { Materials treated } \\
\text { Amounts of } \\
\text { hazardous } \\
\text { material treated } \\
\text { or destroyed } \\
\text { Degree of expected } \\
\text { reductions in } \\
\text { mobility, toxicity, } \\
\text { and volume } \\
\text { Degree to which } \\
\text { treatment is } \\
\text { irreversible } \\
\text { Type and quantity } \\
\text { of residuals } \\
\text { remaining after } \\
\text { treatment }\end{array}$ & $\begin{array}{l}\text { Protection of } \\
\text { community } \\
\text { during remedial } \\
\text { actions } \\
\text { Protection of } \\
\text { workers during } \\
\text { remedial actions } \\
\text { Environmental } \\
\text { impacts } \\
\text { Time period } \\
\text { needed to } \\
\text { achieve remedial } \\
\text { action objectives }\end{array}$ & $\begin{array}{l}\text { Ability to construct and } \\
\text { operate technology } \\
\text { Reliability of technology } \\
\text { Ease of undertaking } \\
\text { additional remedial } \\
\text { actions, if needed } \\
\text { Ability to monitor } \\
\text { effectiveness of remedial } \\
\text { action } \\
\text { Ability to obtain } \\
\text { required approval and } \\
\text { permits } \\
\text { Coordination with other } \\
\text { agencies } \\
\text { Availability and capacity } \\
\text { of off-site treatment/ } \\
\text { storage/disposal facilities } \\
\text { Availability of needed } \\
\text { equipment and services } \\
\text { Availability of } \\
\text { prospective technologies }\end{array}$ & 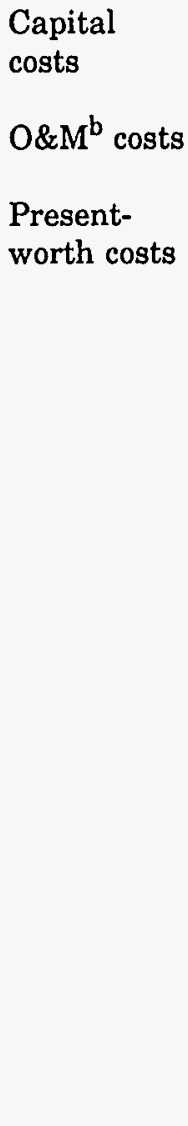 \\
\hline
\end{tabular}

a Applies to both the construction and implementation phases.

b $O \& M=$ operations and maintenance.

Source: Adapted from EPA (1988a). 


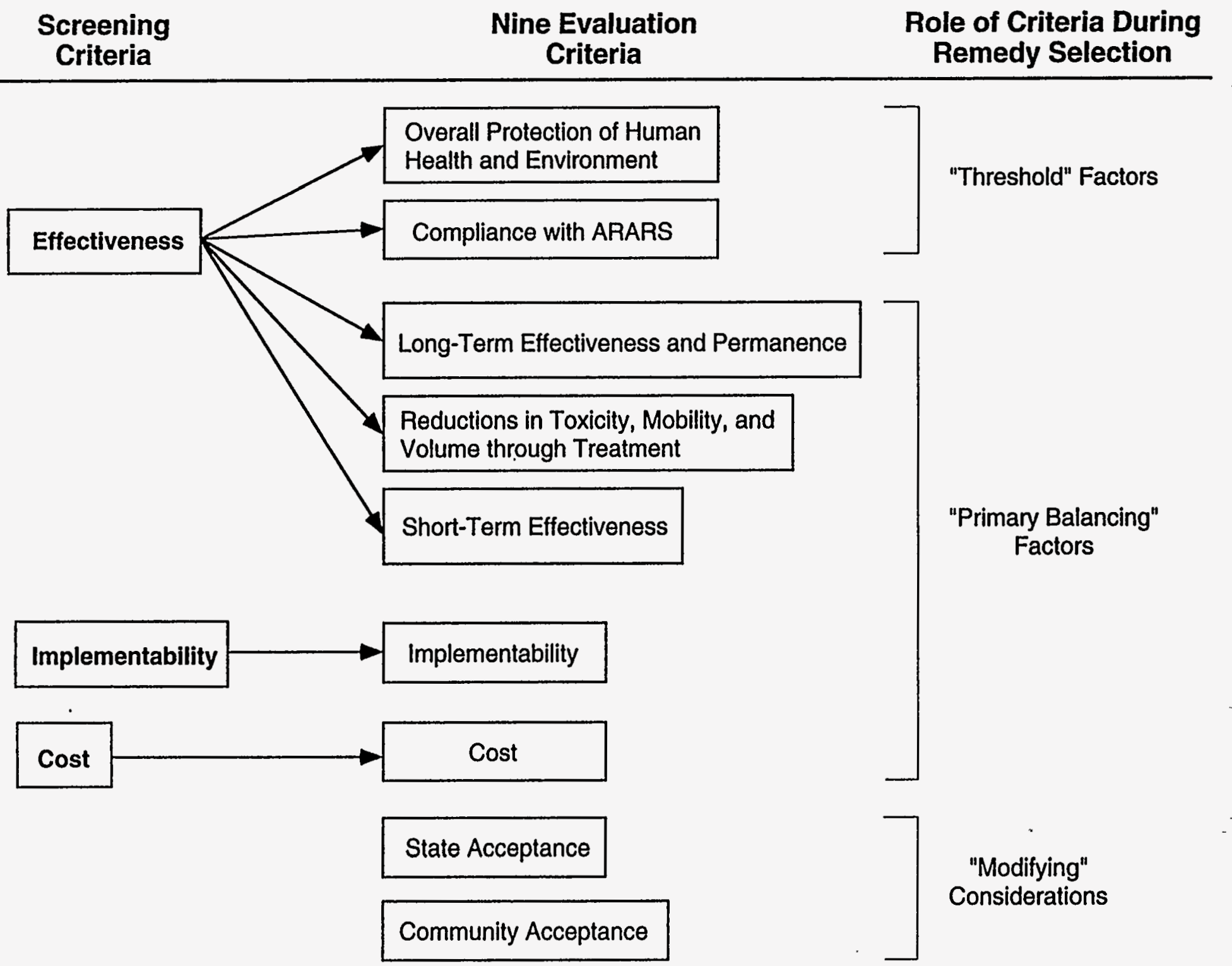

FIGURE 3.3 Relationship of Screening Criteria to the Nine Evaluation Criteria 
The results of the baseline risk assessment can be used to determine if the no-action alternative for soil or groundwater is protective of human health and the environment. If not, additional assessment will be needed to determine if no action for groundwater combined with capping of the soil might achieve the remedial alternative objectives.

\section{Implementability Evaluation}

Implementability is used as a measure of both the technical and administrative feasibility of constructing, operating, and maintaining a remedial action alternative to evaluate the combinations of process options with respect to conditions at a specific site. Evaluation of technical implementability includes consideration of the ability to construct, operate, and meet technology specific regulations for process options until a remedial action is complete. This aspect also includes operation, maintenance, and monitoring of technical operations after a remedial action is complete. Evaluation of administrative implementability is based on the ability to obtain the necessary permits and approval, the availability and capacity of treatment/storage/disposal facilities, and the availability of suitable equipment and skilled workers.

Because $J$-Field is a secured area, permission for access must be coordinated through the U.S. Army Technical Escort Unit and Range Control. Factors that might affect administrative feasibility for each candidate alternative should be addressed.

\section{Cost Evaluation}

Evaluation of the cost of each alternative can be based on material gathered for costing the process options. The procedures used to develop cost estimates for alternative screening are similar to those used for the detailed analysis; the only differences are the degree of alternative refinement and the degree to which cost components are developed.

\subsection{PRELIMINARY IDENTIFICATION OF ARARS AND TO-BE-CONSIDERED INFORMATION}

\subsubsection{Introduction}

Section 121 of CERCLA requires that remediation actions must attain standards, requirements criteria, or limitations that are "legally applicable or relevant and appropriate" requirements (ARARs) under the site-specific scenario for any hazardous substance that will remain on-site after remediation. Section 121 of CERCLA further specifies that state standards can be considered as potential ARARs when they are promulgated standards that are more stringent than federal standards, providing the state standards have been identified in a timely matter during the RI/FS process. 
The distinction between "applicable" and "relevant and appropriate" requirements is made clear in the revised National Contingency Plan (NCP) contained in 40 CFR Part 300.6. In general, the term "applicable requirements" pertains to substantive requirements that relate specifically to a hazardous substance, remedial action, location, or other "circumstance" found at a CERCLA site. Such substantive requirements could include cleanup standards, criteria, or limits promulgated under state or federal statutes. "Relevant and appropriate requirements" are substantive requirements that may not be directly applicable to a specific CERCLA site scenario but are deemed sufficiently similar to such a scenario encountered at a CERCLA site.

Potential requirements for a proposed CERCLA remedial action can also be referred to as "to be considereds" (TBCs). The TBC category consists of standards or guidelines that have been published but not promulgated and that may have significance for all or part of the action. Potential TBC requirements are typically considered only if no promulgated requirements exist that are either applicable or relevant and appropriate.

Although it may be premature to establish specific ARARs and TBCs for J-Field because additional information must be gathered about the site, the early identification of ARARs and TBCs can aid the planning process by allowing investigators to make decisions regarding which remedial alternatives will likely be sufficiently protective and cost effective. The lists of preliminary and potential ARARs presented in Tables 3.2 through 3.5 constitute sets of requirements that can be expanded, reduced, and/or refined as additional information is gathered about the site. The ARARs presented in these tables have been separated into (1) Maryland state regulations and TBCs and (2) federal regulations and TBCs for J-Field. The federal ARARs have been further subdivided into contaminant-specific, location-specific, and action-specific ARARs.

\subsubsection{Contaminant-Specific ARARs}

Contaminant-specific ARARS are methodologies, or health- or risk-based numerical thresholds, that can be applied to site-specific conditions at a CERCLA site to establish standards. Contaminant-specific ARARs establish the allowable amount or concentration of a hazardous substance that may exist or be released to the ambient environment. The list of chemical constituents included in Table 3.3 is somewhat speculative because the investigative effort may not have identified all constituents present at the site. Furthermore, CWAs have not been included in the list because whatever standards or criteria that the U.S. Army may have developed to regulate OB/OD activities have not been promulgated. However, ANL will rely on CWA-related standards or criteria developed by the U.S. Army, the host installation, and associated tenant activities throughout the investigation and remediation of the site. Such CWA-related standards or criteria will be evaluated for inclusion as TBC information. 
TABLE 3.2 State Regulations and To-Be-Considereds for J-Field

\begin{tabular}{|c|c|c|c|c|}
\hline Potential ARAR & Medium $^{a}$ & Requirements & $\begin{array}{c}\text { Preliminary } \\
\text { Determination }\end{array}$ & Remarks \\
\hline $\begin{array}{l}\text { COMAR 14.19, Chesapeake Bay } \\
\text { Critical Area Commission - } \\
\text { Development in the Critical } \\
\text { Area Resulting from State and } \\
\text { Local Agency Programs }\end{array}$ & $\begin{array}{l}\text { Water, } \\
\text { sediment, } \\
\text { soil }\end{array}$ & $\begin{array}{l}\text { Protection of the bay, and criteria for } \\
\text { any development in the bay area. }\end{array}$ & $\begin{array}{l}\text { Potentially } \\
\text { applicable }\end{array}$ & $\begin{array}{l}\text { Applies to Chesapeake Bay only. } \\
\text { The bay borders the site to the south } \\
\text { and may receive discharge from } \\
\text { groundwater aquifers. Potential } \\
\text { impacts will depend on the remedial } \\
\text { actions. }\end{array}$ \\
\hline $\begin{array}{l}\text { Maryland Nonpoint Source } \\
\text { Pollution Control Laws, } \\
\text { Annotated Code of Maryland } 4.1 \\
\text { and } 4.2\end{array}$ & $\begin{array}{l}\text { Water- } \\
\text { sheds }\end{array}$ & $\begin{array}{l}\text { Construction includes soil movement, } \\
\text { grading, transporting, or otherwise } \\
\text { disturbing land. Any such action } \\
\text { undertaken by a federal unit, including } \\
\text { a sediment control plan, must be } \\
\text { reviewed and approved by the } \\
\text { Department. }\end{array}$ & $\begin{array}{l}\text { Potentially } \\
\text { applicable }\end{array}$ & $\begin{array}{l}\text { Any excavation of soils may require } \\
\text { compliance with this law. }\end{array}$ \\
\hline COMAR 26.09.01 and 26.09.02 & $\begin{array}{l}\text { Sediment, } \\
\text { storm } \\
\text { water }\end{array}$ & $\begin{array}{l}\text { Protection of areas for erosion and } \\
\text { sediment control, along with main- } \\
\text { taining predevelopment runoff } \\
\text { characteristics and reducing stream } \\
\text { channel erosion, pollution, siltation and } \\
\text { sedimentation, and local flooding. }\end{array}$ & $\begin{array}{l}\text { Potentially } \\
\text { applicable }\end{array}$ & $\begin{array}{l}\text { Any remedial action must address } \\
\text { these regulations. }\end{array}$ \\
\hline COMAR 8.05 & Wetlands & $\begin{array}{l}\text { It is prohibited to fill, place, dump, or } \\
\text { discharge any dirt, trash, or polluting } \\
\text { substances; to drain, dredge, or remove } \\
\text { soil; to destroy natural vegetation; or to } \\
\text { substantially alter existing patterns of } \\
\text { tidal flow without a permit. }\end{array}$ & $\begin{array}{l}\text { Potentially } \\
\text { relevant and } \\
\text { appropriate }\end{array}$ & $\begin{array}{l}\text { Any remedial action that would } \\
\text { disturb wetlands may require } \\
\text { consultation with the Water } \\
\text { Resource Administration. }\end{array}$ \\
\hline
\end{tabular}


TABLE 3.2 (Cont.)

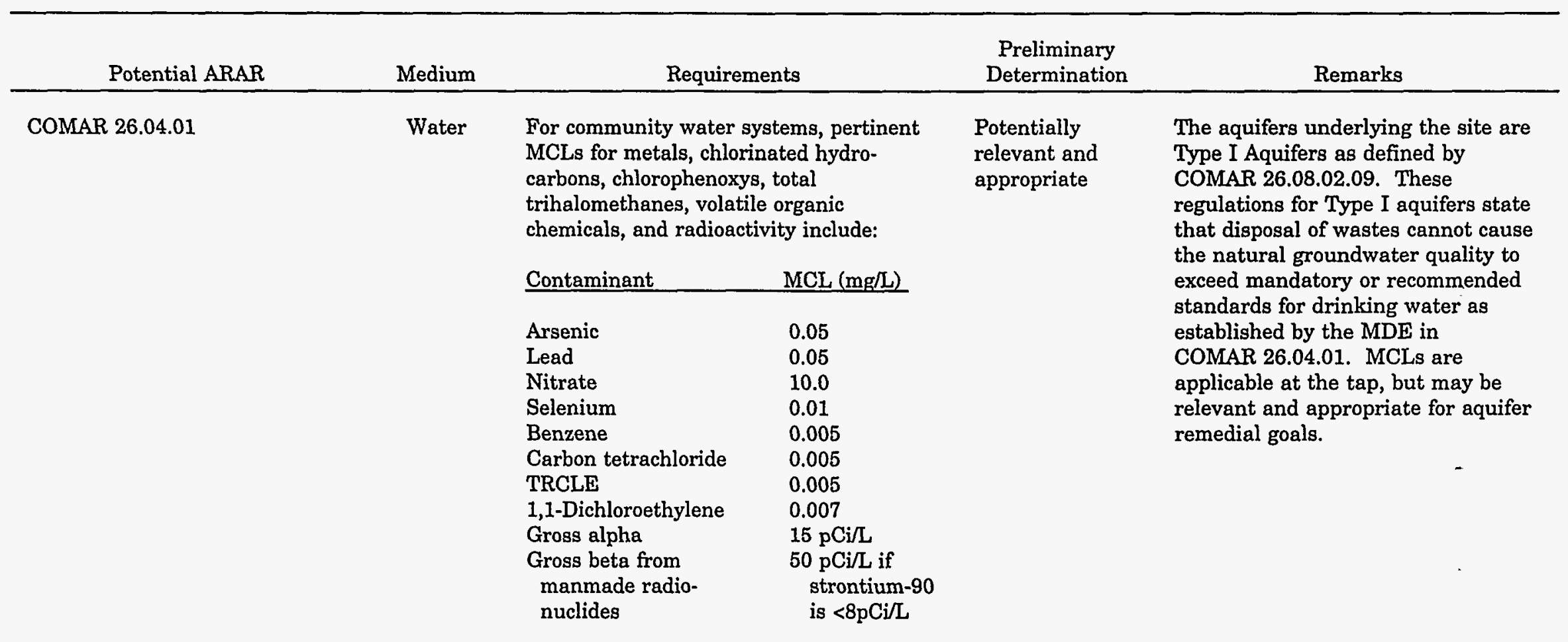


TABLE 3.2 (Cont.)

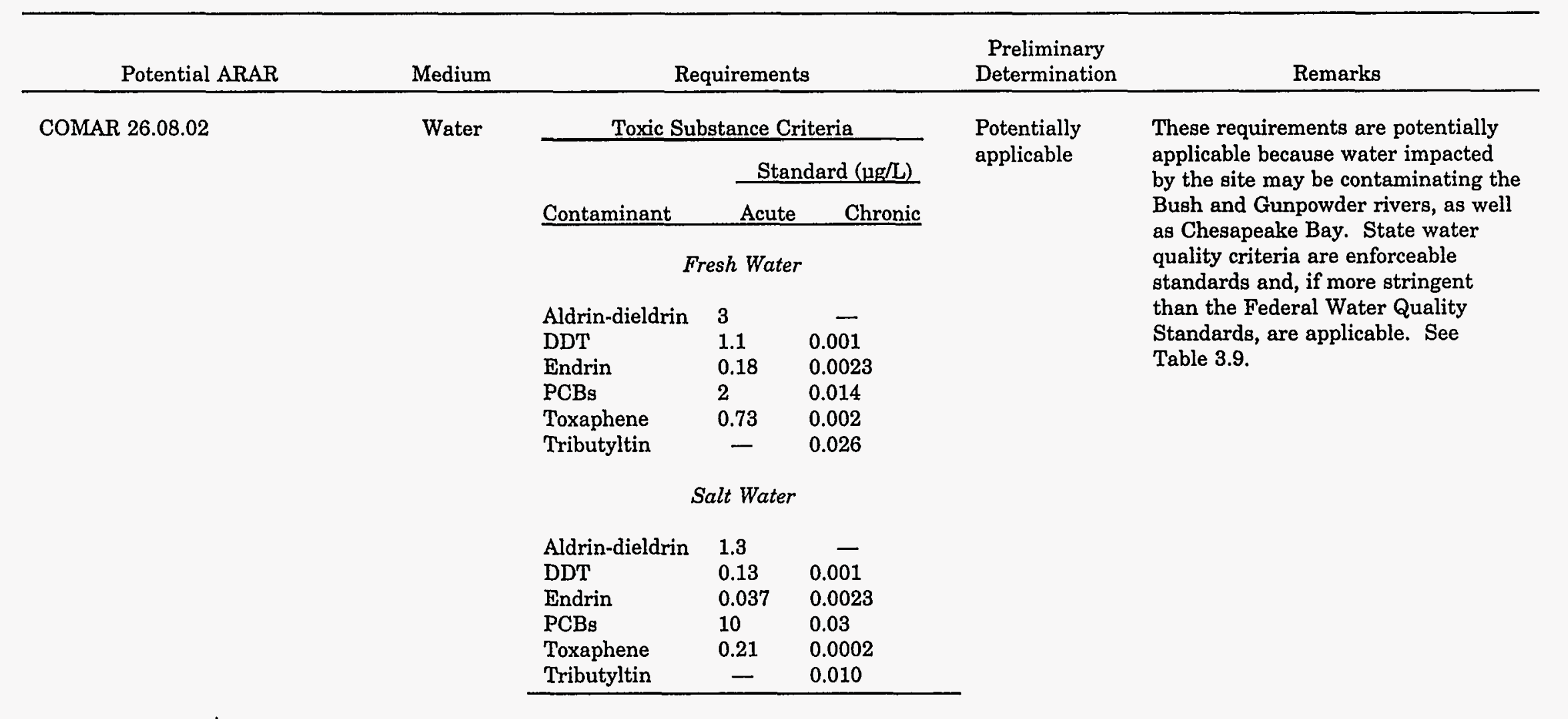


TABLE 3.2 (Cont.)

\begin{tabular}{|c|c|c|c|}
\hline Potential ARAR & Medium & \multicolumn{2}{|c|}{ Requirements } \\
\hline & & \multicolumn{2}{|c|}{$\begin{array}{l}\text { Water Quality Criteria Specific to } \\
\text { Designated Use Classes I and II }\end{array}$} \\
\hline & & Parameter & Criteria \\
\hline & & $\begin{array}{l}\text { Dissolved oxygen } \\
\text { Temperature } \\
\text { pH } \\
\text { Turbidity }\end{array}$ & $\begin{array}{l}>5 \mathrm{mg} / \mathrm{L} \\
\leq 90^{\circ} \mathrm{F} \text { (or the ambient } \\
\text { temperature of the } \\
\text { surface water, } \\
\text { whichever is greater) } \\
6.5-8.5 \\
s 150 \\
s 50 \text { (monthly } \\
\text { average) }\end{array}$ \\
\hline
\end{tabular}

Preliminary

Determination

Remarks

\section{Water Prohibited discharges:}

1. The discharge of any pollutant in toxic amounts including

a. substances that accumulate to toxic amounts during the expected life of organisms in the surface water, or

b. substances that produce deleterious behavioral effects on the organisms.

2. The discharge of any radiological, chemical, or biological warfare agent.

\section{Potentially applicable}

"Discharge" is defined as the addition, introduction, spilling, or emitting of any pollutant to waters of the state; or, the placing of a

pollutant in a location where it is likely to pollute the site. Pollutants have been and are continuing to be discharged to the two estuaries and to Chesapeake Bay; thus, the requirements are potentially applicable. 
TABLE 3.2 (Cont.)

\begin{tabular}{|c|c|c|c|c|}
\hline Potential ARAR & Medium & Requirements & $\begin{array}{c}\text { Preliminary } \\
\text { Determination }\end{array}$ & Remarks \\
\hline $\begin{array}{l}\text { COMAR 26.11.01, 26.11.03, and } \\
26.11 .06\end{array}$ & Air & $\begin{array}{l}\text { State-adapted national ambient air } \\
\text { quality standards and guidelines must } \\
\text { be met for PM-10 24-h, sulfur dioxide, } \\
\text { nitrogen dioxide, and lead. For } \\
\text { particulate matter from materials } \\
\text { handling and construction, reasonable } \\
\text { precautions must be taken to prevent } \\
\text { matter from becoming airborne; i.e, use } \\
\text { of water or chemicals for dust control } \\
\text { during demolition. }\end{array}$ & $\begin{array}{l}\text { Potentially } \\
\text { relevant and } \\
\text { appropriate }\end{array}$ & $\begin{array}{l}\text { In the past, the site has been a } \\
\text { source of emissions. Potential } \\
\text { emissions may occur in the marshes } \\
\text { where CWAs and UXO may exist } \\
\text { and during emergency use of the } \\
\text { TBP and WPP. The site is an } \\
\text { unconfined source in what is termed } \\
\text { an Area III (per } 26.11 .01 \text {, p. 139). } \\
\text { Particulate matter must be } \\
\text { controlled during demolition or other } \\
\text { earth moving activities. }\end{array}$ \\
\hline COMAR 26.11.15 & Air & $\begin{array}{l}\text { General requirements for the discharge } \\
\text { of toxic air pollutants to the atmosphere. } \\
\text { Also outlines procedures for requesting } \\
\text { permits for discharge. }\end{array}$ & $\begin{array}{l}\text { Potentially } \\
\text { applicable }\end{array}$ & $\begin{array}{l}\text { Potentially applicable to any } \\
\text { emissions resulting from remedial } \\
\text { actions, such as in-situ treatment } \\
\text { and pump-and-treat actions. }\end{array}$ \\
\hline COMAR 26.11.21 & Air & $\begin{array}{l}\text { All worker protection requirements must } \\
\text { be followed for asbestos contamination. } \\
\text { Guidelines and standards require } \\
\text { conditions and control features for } \\
\text { asbestos abatement. Also, procedures } \\
\text { are outlined for handling and disposing } \\
\text { of asbestos. }\end{array}$ & $\begin{array}{l}\text { Potentially } \\
\text { applicable }\end{array}$ & $\begin{array}{l}\text { During the remedial action, should } \\
\text { the PB contain asbestos, the } \\
\text { standards and guidelines will have to } \\
\text { be met and followed. Also, asbestos } \\
\text { may have been disposed of in one or } \\
\text { more pits. }\end{array}$ \\
\hline COMAR 26.04.04 & $\begin{array}{l}\text { Ground- } \\
\text { water }\end{array}$ & $\begin{array}{l}\text { General requirements for installing, con- } \\
\text { structing, operating, and abandoning } \\
\text { wells. }\end{array}$ & $\begin{array}{l}\text { Potentially } \\
\text { applicable }\end{array}$ & $\begin{array}{l}\text { Potentially applicable to the con- } \\
\text { struction of wells during remedial } \\
\text { action. }\end{array}$ \\
\hline
\end{tabular}


TABLE 3.2 (Cont.)

\begin{tabular}{|c|c|c|c|c|}
\hline Potential ARAR & Medium & Requirements & $\begin{array}{c}\text { Preliminary } \\
\text { Determination }\end{array}$ & Remarks \\
\hline COMAR 26.08.02 & $\begin{array}{l}\text { Ground- } \\
\text { water }\end{array}$ & $\begin{array}{l}\text { Any discharge to underground waters } \\
\text { requires the approval of the } \\
\text { Department. Maryland regulations } \\
\text { adopt the Underground Injection } \\
\text { Control regulations under } 40 \text { CFR Part } \\
\text { 144. }\end{array}$ & $\begin{array}{l}\text { Potentially } \\
\text { applicable }\end{array}$ & $\begin{array}{l}\text { Reinjection of treated waters into } \\
\text { groundwater would require } \\
\text { compliance with these regulations, if } \\
\text { such injections contain contaminants } \\
\text { that may cause a violation of any } \\
\text { primary drinking water regulations } \\
\text { under } 40 \text { CFR Part } 142 \text { or otherwise } \\
\text { adversely affect human health. }\end{array}$ \\
\hline COMAR 26.04.07 & Solid waste & $\begin{array}{l}\text { General regulations for disposing of } \\
\text { solid waste in a land-based unit, } \\
\text { including procedures for closure and } \\
\text { postclosure. Also, sites that act as a } \\
\text { transfer station or processing facility for } \\
\text { on-site disposal, must follow these } \\
\text { regulations. }\end{array}$ & $\begin{array}{l}\text { Potentially } \\
\text { applicable }\end{array}$ & $\begin{array}{l}\text { Should the remedial action involve } \\
\text { landfilling, transferring, and/or } \\
\text { processing the waste (as defined by } \\
\text { COMAR } 26.04 .07 .02 \text { ), these } \\
\text { regulations must be followed. }\end{array}$ \\
\hline COMAR 26.13.01.05 & $\begin{array}{l}\text { Hazardous } \\
\text { waste }\end{array}$ & $\begin{array}{l}\text { These regulations identify and list } \\
\text { hazardous waste, define hazardous } \\
\text { waste, and present standards applicable } \\
\text { to generators and transporters of } \\
\text { hazardous waste. Also, standards are } \\
\text { presented for owners and operators of } \\
\text { hazardous waste treatment/storage/ } \\
\text { disposal facilities. Standards include } \\
\text { groundwater protection and prohibition } \\
\text { of OB/OD of waste explosives containing } \\
\text { EPA hazardous wastes F020, 8021, } \\
\text { FO22, F023, F026, and F027. } \\
\text { Maryland-listed acute hazardous wastes } \\
\text { include the chemicals GA (tabun), GB } \\
\text { (sarin), GD (soman), VX, L (lewisite), } \\
\text { DM (adamsite), HD (sulfur mustard), T, } \\
\text { waste military CWAs having any } \\
\text { of these substances as their active or } \\
\text { principal ingredient, or mixtures of any } \\
\text { of these substances and any } \\
\text { characteristic or listed hazardous waste. }\end{array}$ & $\begin{array}{l}\text { Potentially } \\
\text { applicable }\end{array}$ & $\begin{array}{l}\text { These requirements are applicable to } \\
\text { any removal actions if the waste at } \\
\text { the site meets the prerequisites for } \\
\text { definition as characteristic or listed } \\
\text { hazardous waste. Also, these } \\
\text { requirements apply to groundwater } \\
\text { contamination and dispersal of } \\
\text { hazardous air pollutants. }\end{array}$ \\
\hline
\end{tabular}


TABLE 3.2 (Cont.)

\begin{tabular}{|c|c|c|c|c|}
\hline Potential ARAR & Medium & Requirements & $\begin{array}{c}\text { Preliminary } \\
\text { Determination }\end{array}$ & Remarks \\
\hline & & $\begin{array}{l}\text { Maryland-listed hazardous waste from } \\
\text { specific sources includes residues from } \\
\text { the treatment of the above-listed wastes, } \\
\text { except when treated at the following: } \\
\text { - U.S. Army APG/U.S. Army Chemical } \\
\text { Research Development and } \\
\text { Engineering Center; } \\
\text { U.S. Army Product Assurance } \\
\text { Directorate, APG; or } \\
\text { U.S. Army APG/Medical Research } \\
\text { Institute of Chemical Defense; } \\
\text { under the protocol, "To Support the } \\
\text { Delisting of Decontaminated Liquid } \\
\text { Chemical Surety Materials as } \\
\text { Hazardous Waste from Specific Sources } \\
\text { COMAR 26.13.02.167 and } 26.13 .02 .18 \\
\text { K991-K999 and Residues from } \\
\text { K991-K999" (U.S. Army Chemical } \\
\text { Research Development and Engineering } \\
\text { Center. APG, Md. 1988). }\end{array}$ & & \\
\hline
\end{tabular}


TABLE 3.3 Federal Regulations and To-Be-Considereds for J-Field - Potential Contaminant-Specific Requirements

\begin{tabular}{|c|c|c|c|c|c|}
\hline Potential ARARs & Contaminant & Medium & Requirements & $\begin{array}{c}\text { Preliminary } \\
\text { Determination }\end{array}$ & Remarks \\
\hline \multirow[t]{2}{*}{$\begin{array}{l}\text { Clean Air Act, as amended } \\
\text { (42 USC 7401-7642); } \\
\text { National Primary and } \\
\text { Secondary Ambient Air } \\
\text { Quality Standards } \\
\text { (40 CFR Part 50) }\end{array}$} & $\begin{array}{l}\text { Particulate } \\
\text { matter }\end{array}$ & Air & $\begin{array}{l}\text { For a major stationary source } \\
\text { [see } 40 \mathrm{CFR} 52.2(\mathrm{~b})(1)(\mathrm{i})(\mathrm{a}) \text { ] that } \\
\text { emits }>250 \text { tons } / \mathrm{yr} \text { of any } \\
\text { regulated pollutant or } \\
>100 \text { tons/yr of a regulated } \\
\text { pollutant for which the area is } \\
\text { designated as nonattainment, } \\
\text { PM- } 10 \text { should not exceed a } 24-\mathrm{h} \\
\text { average concentration of } \\
150 \mu \mathrm{gg} / \mathrm{m}^{3} \text { or an annual arith- } \\
\text { metic mean of } 50 \mu g / \mathrm{m}^{3} \text {. }\end{array}$ & $\begin{array}{l}\text { Potentially } \\
\text { relevant and } \\
\text { appropriate }\end{array}$ & $\begin{array}{l}\text { These requirements do not apply } \\
\text { directly to source-specific } \\
\text { emissions; rather, they are } \\
\text { national limitations on ambient } \\
\text { concentrations. However, they will } \\
\text { be addressed in controlling } \\
\text { particulate emissions that could } \\
\text { result from implementation of a } \\
\text { remedial action. }\end{array}$ \\
\hline & Lead & Air & $\begin{array}{l}\text { As for the above conditions, the } \\
\text { standard for lead and its } \\
\text { compounds, as elemental lead, is } \\
1.5 \mu \mathrm{g} / \mathrm{m}^{3} \text { maximum arithmetic } \\
\text { mean averaged over one } \\
\text { calendar quarter. }\end{array}$ & $\begin{array}{l}\text { Potentially } \\
\text { relevant and } \\
\text { appropriate }\end{array}$ & $\begin{array}{l}\text { These requirements do not apply } \\
\text { directly to source-specific } \\
\text { emissions; rather, they are } \\
\text { national limitations on ambient } \\
\text { concentrations. However, they will } \\
\text { be addressed in controlling lead } \\
\text { emissions that could result from } \\
\text { implementation of a remedial } \\
\text { action. }\end{array}$ \\
\hline $\begin{array}{l}\text { OSHA Standards, } \\
\text { Occupational Health and } \\
\text { Environmental Control } \\
\text { [29 CFR } 1910.95(\mathrm{~g})]\end{array}$ & Noise & Air & $\begin{array}{l}\text { The permissible occupational } \\
\text { exposure level for noise is } \\
90 \mathrm{dBA} \text { (slow response) for an } 8 \text { - } \\
\text { h day; with decreasing times of } \\
\text { exposure, the levels increase to } \\
115 \mathrm{dBA} \text { per } 15 \text {-min day. }\end{array}$ & $\begin{array}{l}\text { Potentially } \\
\text { applicable }\end{array}$ & $\begin{array}{l}\text { These requirements are part of an } \\
\text { employee protection law (rather } \\
\text { than an environmental law) with } \\
\text { which all CERCLA response } \\
\text { actions should comply. Because } \\
\text { this compliance is directly } \\
\text { required, as promulgated in the } \\
\text { NCP, these requirements are not } \\
\text { subject to evaluation for } \\
\text { attainment or waiver as part of the } \\
\text { ARAR process. However, they } \\
\text { constitute requirements for worker } \\
\text { protection with which any remedial } \\
\text { action will comply. }\end{array}$ \\
\hline
\end{tabular}


TABLE 3.3 (Cont.)

\begin{tabular}{|c|c|c|c|c|c|}
\hline Potential ARARs & Contaminant & Medium & Requirements & $\begin{array}{c}\text { Preliminary } \\
\text { Determination }\end{array}$ & Remarks \\
\hline $\begin{array}{l}\text { TSCA, as amended (15 } \\
\text { USC 2607-2629, PL 94-469 } \\
\text { et seq.); Polychlorinated } \\
\text { Biphenyls Manufacturing, } \\
\text { Processing, Distribution in } \\
\text { Commerce, and Use } \\
\text { Prohibitions [40 CFR } \\
\text { Part 761(g)] }\end{array}$ & $\mathrm{PCBs}$ & Soil & $\begin{array}{l}\text { For spills of materials } \\
\text { contaminated with }>50 \mathrm{ppm} \\
\text { PCBs in unrestricted-access } \\
\text { areas (e.g., residential areas), } \\
\text { soil within the spill area must be } \\
\text { excavated and backfilled with } \\
\text { soil containing < } 1 \mathrm{ppm} \text { PCBs. } \\
\text { Contaminated soil may be } \\
\text { decontaminated to } 10 \mathrm{ppm} \text { by } \\
\text { weight by excavating a minimum } \\
\text { of } 10 \text { in. and backfilling with soil } \\
\text { containing <1 ppm PCBs. For } \\
\text { spills at outdoor electrical } \\
\text { substations, the soil must be } \\
\text { cleaned to } 25 \text { ppm by weight (as } \\
\text { for other restricted-access areas) } \\
\text { or to } 50 \text { ppm by weight with } \\
\text { posting of a visible notice. }\end{array}$ & $\begin{array}{l}\text { Potentially } \\
\text { relevant and } \\
\text { appropriate }\end{array}$ & $\begin{array}{l}\text { Any such spills at the site would } \\
\text { have preceded the effective date of } \\
\text { this requirement; hence, it is not } \\
\text { applicable. However, it may be } \\
\text { considered relevant and appro- } \\
\text { priate to the remedial action. }\end{array}$ \\
\hline $\begin{array}{l}\text { Safe Drinking Water Act } \\
\text { (42 USC 300G, } \\
\text { PL 93-523); } \\
\text { National Primary } \\
\text { Drinking Water Regula- } \\
\text { tions [40 CFR Part } \\
\text { 141(b)(g)]; } \\
\text { National Secondary } \\
\text { Drinking Water Regula- } \\
\text { tions (40 CFR Part 143) }\end{array}$ & Any & Water & $\begin{array}{l}\text { See } 40 \text { CFR Parts } 141 \text { and } 143 \\
\text { for MCLs and secondary MCLs } \\
\text { for drinking water delivered } \\
\text { directly to the ultimate user of a } \\
\text { public water system. }\end{array}$ & $\begin{array}{l}\text { Potentially } \\
\text { relevant and } \\
\text { appropriate }\end{array}$ & $\begin{array}{l}\text { These requirements are potentially } \\
\text { relevant and appropriate because } \\
\text { contaminated aquifers under the } \\
\text { site have potential use for drinking } \\
\text { water. Also, proposed rules ( } 54 \mathrm{FR} \\
\text { Part } 97 \text { and } 53 \text { FR Part 160) for } \\
\text { MCLs and secondary MCLs should. } \\
\text { be considered (although levels set } \\
\text { at } 0 \text { do not apply at CERCLA } \\
\text { action sites), and are required } \\
\text { regulations when promulgated. }\end{array}$ \\
\hline
\end{tabular}


TABLE 3.3 (Cont.)

\begin{tabular}{|c|c|c|c|c|c|}
\hline Potential ARARs & Contaminant & Medium & Requirements & $\begin{array}{c}\text { Preliminary } \\
\text { Determination }\end{array}$ & Remarks \\
\hline $\begin{array}{l}\text { Federal Water Pollution } \\
\text { Control Act, Clean Water } \\
\text { Act (33 USC 1251-1376); } \\
\text { Water Quality Criteria } \\
\text { (40 CFR Part 122) }\end{array}$ & Any & Water & $\begin{array}{l}\text { Concentration limits for a long } \\
\text { list of contaminants in surface } \\
\text { water are specified for the } \\
\text { protection of human health and } \\
\text { aquatic life. See } 40 \text { CFR } \\
\text { Part 122, Table A.5. }\end{array}$ & To be considered & $\begin{array}{l}\text { Federal water quality criteria are } \\
\text { nonenforceable guidelines used by } \\
\text { states and the federal government } \\
\text { to set water quality standards for } \\
\text { surface water; however, they may } \\
\text { be relevant and appropriate if the } \\
\text { water concerned is a public water } \\
\text { supply or if fishing is also included } \\
\text { in the state's designated use of the } \\
\text { waters concerned. If a state has } \\
\text { promulgated a numerical water } \\
\text { quality standard for a given } \\
\text { contaminant, the state standard } \\
\text { rather than the federal water } \\
\text { quality criteria would be relevant } \\
\text { and appropriate. }\end{array}$ \\
\hline $\begin{array}{l}\text { Solid Waste Disposal Act, } \\
\text { as amended ( } 42 \text { USC } 6901 \text {, } \\
\text { et seq.); } \\
\text { Solid Wastes } \\
{[40 \text { CFR } 261(c)(d)]}\end{array}$ & Any & $\begin{array}{l}\text { Solid } \\
\text { waste }\end{array}$ & $\begin{array}{l}\text { A waste must be evaluated to } \\
\text { determine whether it is a } \\
\text { hazardous waste, i.e., either a } \\
\text { listed waste or a characteristic } \\
\text { waste. A characteristic waste is } \\
\text { determined by its (1) ignitability, } \\
\text { (2) corrosivity, (3) reactivity, or } \\
\text { (4) leachability, as defined by } \\
\text { TCLP for several contaminants. } \\
\text { See } 40 \text { CFR Part } 261 \text {. }\end{array}$ & $\begin{array}{l}\text { Potentially } \\
\text { applicable }\end{array}$ & $\begin{array}{l}\text { This requirement is applicable to } \\
\text { the characterization and } \\
\text { management of site waste. One or } \\
\text { two samples have shown the } \\
\text { presence of leachable lead. } \\
\text { Further characterization is } \\
\text { ongoing. }\end{array}$ \\
\hline
\end{tabular}

Solid Waste Disposal Act, Any as amended (42 USC 6901

Solid Wastes 
TABLE 3.4 Federal Regulations and To-Be-Considereds for J-Field - Potential Location-Specific Requirements

\begin{tabular}{|c|c|c|}
\hline Potential ARARs & Location & Requirements \\
\hline $\begin{array}{l}\text { Antiquity Act, Historic Sites } \\
\text { Act [16 USC } 431-433,16 \text { USC } \\
461-467,40 \text { CFR } 6.301 \text { (a)] }\end{array}$ & Land & $\begin{array}{l}\text { Cultural resources, such as historic } \\
\text { buildings and sites and natural land- } \\
\text { marks, must be preserved on federal } \\
\text { land to avoid adverse impacts. }\end{array}$ \\
\hline $\begin{array}{l}\text { National Historic Preservation } \\
\text { Act, as amended [16 USC } 470 \\
\text { et seq., } 40 \text { CFR } 6.301(\mathrm{~b}) \text {, } \\
36 \text { CFR Part } 800 \text { ] }\end{array}$ & Land & $\begin{array}{l}\text { The effect of any federally assisted } \\
\text { undertaking must be taken into } \\
\text { account for any district, site, building, } \\
\text { structure, or object included in or } \\
\text { eligible for the National Register of } \\
\text { Historic Places. }\end{array}$ \\
\hline $\begin{array}{l}\text { Archaeological and Historic } \\
\text { Preservation Act [16 USC } 469 \text {, } \\
40 \text { CFR } 6.301(\mathrm{c}), \text { PL 93-291, } \\
88 \text { Stat. 174] }\end{array}$ & Land & $\begin{array}{l}\text { Prehistorical, historical, and archae- } \\
\text { ological data that might be destroyed } \\
\text { as a result of a federal, federally } \\
\text { assisted, or federally licensed activity } \\
\text { or program must be preserved. }\end{array}$ \\
\hline $\begin{array}{l}\text { Archaeological Resources Pro- } \\
\text { tection Act [16 USC } 470(\mathrm{a}) \text { ] }\end{array}$ & Land & $\begin{array}{l}\text { A permit must be obtained if an action } \\
\text { on public or Native American lands } \\
\text { could affect archaeological resources. }\end{array}$ \\
\hline $\begin{array}{l}\text { Protection and Enhancement } \\
\text { of the Cultural Environment } \\
\text { (EO 11593, } 40 \text { CFR 6.301) }\end{array}$ & Land & $\begin{array}{l}\text { Historic, architectural, archaeological, } \\
\text { and cultural resources must be } \\
\text { preserved, restored, and maintained, } \\
\text { and must be evaluated for inclusion in } \\
\text { the National Register. }\end{array}$ \\
\hline $\begin{array}{l}\text { Endangered Species Act, as } \\
\text { amended [16 USC 1531-1543, } \\
50 \text { CFR } 17.402 \text {, } \\
40 \text { CFR } 6.302(\mathrm{~h})]\end{array}$ & Any & $\begin{array}{l}\text { Federal agencies must ensure that any } \\
\text { action authorized, funded, or carried } \\
\text { out by the agency is not likely to } \\
\text { jeopardize the continued existence of } \\
\text { any threatened or endangered species } \\
\text { or destroy or adversely modify any } \\
\text { critical habitat. }\end{array}$ \\
\hline
\end{tabular}

Preliminary

Determination

Remarks

Potentially

applicable

Potentially applicable

Potentially applicable

Potentially applicable

Potentially applicable

Potentially applicable
Should this site be identified as a cultural resource, the requirement could be potentially applicable during a remedial action.

Should such a property be identified, the requirement would be potentially applicable during a remedial action.

Should such data be identified, the requirement would be potentially applicable during a remedial action.

Should such resources be identified, the requirement would be potentially applicable during a remedial action.

Should such resources be identified, the requirement would be potentially applicable during a remedial action.

Should such species or habitat exist, the requirement would be potentially applicable during a remedial action. 
TABLE 3.4 (Cont.)

\begin{tabular}{|c|c|c|c|c|}
\hline Potential ARARs & Location & Requirements & $\begin{array}{c}\text { Preliminary } \\
\text { Determination }\end{array}$ & Remarks \\
\hline $\begin{array}{l}\text { Fish and Wildlife Coordination } \\
\text { Act [14 USC } 441-444 \text {, } \\
40 \text { CFR } 4.302(a) \text { ] }\end{array}$ & Any & $\begin{array}{l}\text { Adequate protection of fish and wildlife } \\
\text { resources is required when any federal } \\
\text { department or agency proposes or } \\
\text { authorizes any modification (e.g., } \\
\text { diversion or channeling) of any stream } \\
\text { or other water body or any modification } \\
\text { of areas affecting any stream or other } \\
\text { water body. }\end{array}$ & $\begin{array}{l}\text { Potentially } \\
\text { applicable }\end{array}$ & $\begin{array}{l}\text { Should modification of any stream or } \\
\text { any other water bodies or areas } \\
\text { affecting water bodies be required } \\
\text { during a remedial action, the } \\
\text { requirement would be potentially } \\
\text { applicable. }\end{array}$ \\
\hline $\begin{array}{l}\text { Floodplain Management } \\
\text { (EO 11988) }\end{array}$ & Floodplain & $\begin{array}{l}\text { Federal agencies must avoid, to the } \\
\text { maximum extent possible, any adverse } \\
\text { impacts associated with direct and } \\
\text { indirect development of a floodplain. }\end{array}$ & $\begin{array}{l}\text { Potentially } \\
\text { applicable }\end{array}$ & $\begin{array}{l}\text { The site is within the } 100 \text {-year } \\
\text { floodplain. }\end{array}$ \\
\hline $\begin{array}{l}\text { Protection of Wetlands } \\
\text { (EO 11990) }\end{array}$ & Wetlands & $\begin{array}{l}\text { Federal agencies must avoid, to the } \\
\text { extent possible, any adverse impacts } \\
\text { associated with the destruction or loss } \\
\text { of wetlands and the support of new } \\
\text { construction in wetlands if a } \\
\text { practicable alternative exists. }\end{array}$ & $\begin{array}{l}\text { Potentially } \\
\text { applicable }\end{array}$ & Wetlands exist in the affected area. \\
\hline
\end{tabular}


TABLE 3.5 Federal Regulations and To-Be-Considereds for J-Field - Potential Action-Specific Requirements

\begin{tabular}{|c|c|c|c|c|}
\hline Potential ARARs & Action & Requirements & $\begin{array}{c}\text { Preliminary } \\
\text { Determination }\end{array}$ & Remarks \\
\hline $\begin{array}{l}\text { Hazardous Material } \\
\text { Transportation Act, as } \\
\text { amended (49 USC 1801- } \\
\text { 1812); } \\
\text { Solid Wastes ( } 40 \text { CFR } \\
\text { Part 263) }\end{array}$ & Transportation & $\begin{array}{l}\text { Generic requirements are established, } \\
\text { as are procedures for transporting } \\
\text { hazardous waste, for minimizing the } \\
\text { environmental impacts of spills or } \\
\text { releases of hazardous materials. }\end{array}$ & $\begin{array}{l}\text { Potentially } \\
\text { applicable }\end{array}$ & $\begin{array}{l}\text { These requirements are not part of } \\
\text { an environmental law and hence are } \\
\text { not subject to evaluation for attain- } \\
\text { ment or waiver as part of the ARAR } \\
\text { process. However, they could be } \\
\text { pertinent to any remedial action in } \\
\text { which hazardous waste is trans- } \\
\text { ported off-site. In this case, the } \\
\text { pertinent requirements (e.g., for spill } \\
\text { response) would be addressed during } \\
\text { implementation. }\end{array}$ \\
\hline $\begin{array}{l}\text { Noise Control Act, as } \\
\text { amended; Noise Pollution } \\
\text { and Abatement Act } \\
\text { (42 USC } 4901 \text { et seq.) }\end{array}$ & $\begin{array}{l}\text { Detonation, } \\
\text { heavy } \\
\text { equipment } \\
\text { usage }\end{array}$ & $\begin{array}{l}\text { The public must be protected from noises } \\
\text { (e.g., that could result from remedial } \\
\text { action activities) that jeopardize health or } \\
\text { welfare. }\end{array}$ & $\begin{array}{l}\text { Potentially } \\
\text { applicable }\end{array}$ & $\begin{array}{l}\text { This requirement is potentially } \\
\text { applicable if during a remedial action } \\
\text { any detonation of UXO occurs and } \\
\text { heavy equipment is used. }\end{array}$ \\
\hline $\begin{array}{l}\text { OSHA Standards for } \\
\text { Hazardous Waste } \\
\text { Operations and } \\
\text { Emergency Response } \\
\text { (29 CFR Part 1910) }\end{array}$ & $\begin{array}{l}\text { Waste } \\
\text { management }\end{array}$ & $\begin{array}{l}\text { General worker protection requirements } \\
\text { are established, as are requirements for } \\
\text { worker training and the development of } \\
\text { an emergency response plan and a safety } \\
\text { and health program for employees. In } \\
\text { addition, procedures are established for } \\
\text { hazardous waste operations, including } \\
\text { decontamination and drum/container } \\
\text { handling (e.g., for radioactive waste, } \\
\text { asbestos, and PCBs). }\end{array}$ & $\begin{array}{l}\text { Potentially } \\
\text { applicable }\end{array}$ & $\begin{array}{l}\text { These requirements are parts of an } \\
\text { employee protection law (rather than } \\
\text { an environmental law) with which all } \\
\text { CERCLA response actions should } \\
\text { comply. Because this compliance is } \\
\text { directly required, as promulgated in } \\
\text { the NCP, these requirements are not } \\
\text { subject to evaluation for attainment } \\
\text { or waiver as part of the ARAR } \\
\text { process. However, they constitute } \\
\text { requirements for worker protection } \\
\text { with which a remedial action will } \\
\text { comply. }\end{array}$ \\
\hline
\end{tabular}


TABLE 3.5 (Cont.)

\begin{tabular}{|c|c|c|c|c|}
\hline Potential ARARs & Action & Requirements & $\begin{array}{c}\text { Preliminary } \\
\text { Determination }\end{array}$ & Remarks \\
\hline $\begin{array}{l}\text { TSCA, as amended } \\
\text { (15 USC 2607-2629, } \\
\text { PL 94-469 et seq.); } \\
\text { Polychlorinated Biphenyls } \\
\text { Manufacturing, Proces- } \\
\text { sing, Distribution in } \\
\text { Commerce, and Use } \\
\text { Prohibitions [40 CFR } \\
761(a) \text { ] }\end{array}$ & PCB testing & $\begin{array}{l}\text { Inspection and testing are required for } \\
\text { material contaminated with PCBs. }\end{array}$ & $\begin{array}{l}\text { Potentially } \\
\text { applicable }\end{array}$ & $\begin{array}{l}\text { This requirement may be applicable } \\
\text { to characterization of site waste for } \\
\text { PCBs. }\end{array}$ \\
\hline $\begin{array}{l}\text { TSCA, as amended } \\
\text { (15 USC 2607-2629, } \\
\text { PL 94-499, et seq.) } \\
\text { Polychlorinated Biphenyls } \\
\text { Manufacturing, Proces- } \\
\text { sing, Distribution in } \\
\text { Commerce, and Use Prohi- } \\
\text { bitions [40 CFR } 761(d) \text { ] }\end{array}$ & $\begin{array}{l}\text { PCB storage } \\
\text { and disposal }\end{array}$ & $\begin{array}{l}\text { When material contaminated with PCBs } \\
>50 \mathrm{ppm} \text { is stored, the facility used for } \\
\text { storage must be marked as such and } \\
\text { must not be located in a } 100 \text {-year } \\
\text { floodplain. Disposal of material } \\
\text { contaminated with PCBs }>50 \mathrm{ppm} \\
\text { requires either incineration or chemical } \\
\text { waste landfilling at EPA-approved } \\
\text { facilities. }\end{array}$ & $\begin{array}{l}\text { Potentially } \\
\text { relevant and } \\
\text { appropriate }\end{array}$ & $\begin{array}{l}\text { These requirements are potentially } \\
\text { relevant and appropriate because } \\
\text { disposal of material from the site } \\
\text { that may be contaminated with } \mathrm{PCBs} \\
\text { may be included in the scope of the } \\
\text { remedial action. }\end{array}$ \\
\hline $\begin{array}{l}\text { Solid Waste Disposal Act, } \\
\text { as amended ( } 42 \text { USC } \\
6901 \text {, et seq.); } \\
\text { Solid Wastes [ } 40 \cdot \text { CFR } \\
\text { 264(b-e)] }\end{array}$ & $\begin{array}{l}\text { Waste treat- } \\
\text { ment, storage, } \\
\text { and disposal }\end{array}$ & $\begin{array}{l}\text { General requirements are established for } \\
\text { storage, treatment, and disposal facility } \\
\text { location, design, and inspection; waste } \\
\text { compatibility determination; emergency } \\
\text { contingency plans; preparedness plans; } \\
\text { recordkeeping; reporting; and worker } \\
\text { training. Location requirements include } \\
\text { (1) facilities must not be located within } \\
61 \mathrm{~m}(200 \mathrm{ft} \text { ) of an active fault and } \\
(2) \text { facilities located in a } 100 \text {-year } \\
\text { floodplain must be constructed, operated, } \\
\text { and maintained to prevent washout of } \\
\text { any hazardous waste by a } 100 \text {-year flood. }\end{array}$ & $\begin{array}{l}\text { Potentially } \\
\text { applicable }\end{array}$ & $\begin{array}{l}\text { These requirements are potentially } \\
\text { applicable because storage, } \\
\text { treatment, or disposal, as defined } \\
\text { under RCRA, may be included in the } \\
\text { scope of a remedial action. In } \\
\text { addition, the ongoing OB/OD } \\
\text { activities at J-Field will mean that } \\
\text { Subpart X, Miscellaneous Units, } \\
\text { could be a key ARAR. }\end{array}$ \\
\hline
\end{tabular}


TABLE 3.5 (Cont.)

\begin{tabular}{|c|c|c|c|c|}
\hline Potential ARARs & Action & Requirements & $\begin{array}{c}\text { Preliminary } \\
\text { Determination }\end{array}$ & Remarks \\
\hline $\begin{array}{l}\text { Solid Waste Disposal Act, } \\
\text { as amended ( } 42 \text { USC } \\
6901 \text {, et seq.); } \\
\text { Solid Wastes } \\
\text { [40 CFR 264(f]) }\end{array}$ & Waste disposal & $\begin{array}{l}\text { A groundwater monitoring system must } \\
\text { be maintained for a SWMU. The } \\
\text { concentration of a hazardous constituent } \\
\text { in the uppermost aquifer beneath a } \\
\text { regulated unit is not to exceed the } \\
\text { existing background concentration or a } \\
\text { listed maximum concentration if higher } \\
\text { than the background level, or an } \\
\text { alternate concentration limit, unless an } \\
\text { exemption is granted. See } 40 \text { CFR } \\
\text { Part } 264 \text { for organic and inorganic } \\
\text { parameter requirements. }\end{array}$ & $\begin{array}{l}\text { Potentially } \\
\text { applicable }\end{array}$ & $\begin{array}{l}\text { These requirements are potentially } \\
\text { applicable if the scope of a remedial } \\
\text { action includes maintaining or } \\
\text { capping a SWMU. }\end{array}$ \\
\hline $\begin{array}{l}\text { Solid Waste Disposal Act, } \\
\text { as amended ( } 42 \text { USC } \\
6901 \text {, et seq.); } \\
\text { Solid Wastes ( } 40 \text { CFR } \\
264(i)]\end{array}$ & Waste storage & $\begin{array}{l}\text { Containers used to store hazardous waste } \\
\text { must be closed and in good condition. }\end{array}$ & $\begin{array}{l}\text { Potentially } \\
\text { applicable }\end{array}$ & $\begin{array}{l}\text { These requirements may be } \\
\text { applicable to the remedial action, } \\
\text { container storage, and transportation } \\
\text { of site waste that meets the pre- } \\
\text { requisites for definition as } \\
\text { characteristic hazardous waste. }\end{array}$ \\
\hline $\begin{array}{l}\text { Solid Waste Disposal Act, } \\
\text { as amended ( } 42 \text { USC } \\
6901 \text {, et seq.); } \\
\text { Land Disposal Restrictions } \\
\text { [40 CFR 268(c)] }\end{array}$ & Waste disposal & $\begin{array}{l}\text { The land disposal of certain hazardous } \\
\text { waste (e.g., contaminated soil and debris) } \\
\text { without proper treatment is restricted, } \\
\text { unless a treatability variance is appro- } \\
\text { priate. Such treatment must attain } \\
\text { levels achievable by the "best demon- } \\
\text { strated available technologies" for each } \\
\text { hazardous constituent in the listed waste. }\end{array}$ & $\begin{array}{l}\text { Potentially } \\
\text { applicable }\end{array}$ & $\begin{array}{l}\text { These requirements are potentially } \\
\text { applicable for any remedial action at } \\
\text { J-Field that includes disposal or any } \\
\text { consolidation of site waste into a new } \\
\text { disposal or storage area. }\end{array}$ \\
\hline
\end{tabular}




\subsubsection{Location-Specific ARARs}

Location-specific ARARs, relate to limitations placed on the concentrations of hazardous substance or performance standards established for particular locations. Relevant locations could include threatened or endangered species habitats or other sensitive ecosystems or habitats, wetlands, floodplains, or historic or archaeological sites.

\subsubsection{Action-Specific ARARs}

Action-specific ARARs are technology- or performance-based standards that relate to actions associated with remediation of the site.

\subsection{PRELIMINARY REMEDIATION GOALS}

Preliminary remediation goals can be developed for the operable units at J-Field on the basis of the existing information. These goals, which are in essence preliminary cleanup levels, require information on the environmental media of concern, the chemicals of concern, and the probable land use for each operable unit at J-Field (EPA 1991a).

\subsubsection{Environmental Media of Concern and Potential Concern -}

It is useful to distinguish environmental media that are of concern and of potential concern. A medium is of concern if existing analytical data are sufficient to show that the medium is contaminated. A medium is of potential concern if the existing sampling data for the medium are insufficient to show contamination, but sampling data for other media or the site history indicate a potential for contamination. The status of the environmental media for the eight $J$-Field sites is summarized in Table 3.6. Details are provided in the following subsections.

\subsubsection{Toxic Burning Pits}

Existing analytical data indicate that soil and groundwater are environmental media of concern at the TBP AOC. Surface water and sediments in the adjacent marshes are media of potential concern. No existing analytical data show that these media are contaminated, but the possibility of surface runoff into the marshes to the east and south, pushout of burned soil and debris into the marshes, and general J-Field history indicate a potential for concern. The elevated soil-gas contamination in the area and the possible existence of contaminated fugitive dust indicate that the atmosphere may also be a medium of potential concern. 
TABLE 3.6 Environmental Media of Concern or Potential Concern at the J-Field Sites

\begin{tabular}{|c|c|c|c|c|c|c|}
\hline \multirow[b]{2}{*}{ Site } & \multicolumn{6}{|c|}{ Concern $(\mathrm{Y})$ or Potential Concern $(\mathrm{P})^{\mathbf{a}}$} \\
\hline & Soil & $\begin{array}{c}\text { Marsh } \\
\text { Sediment }\end{array}$ & $\begin{array}{l}\text { Offshore } \\
\text { Sediment }\end{array}$ & $\begin{array}{c}\text { Surface } \\
\text { Water }\end{array}$ & $\begin{array}{l}\text { Ground- } \\
\text { water }\end{array}$ & $\begin{array}{l}\text { Atmo- } \\
\text { sphere }\end{array}$ \\
\hline Toxic Burning Pits (TBP) & $\mathrm{Y}$ & $\mathrm{P}$ & - & $\mathbf{P}$ & $\mathrm{Y}$ & $\mathrm{P}$ \\
\hline $\begin{array}{l}\text { White Phosphorus } \\
\text { Burning Pits (WPP) }\end{array}$ & $\mathrm{Y}$ & - & $\mathrm{P}$ & $\mathrm{P}$ & $\mathrm{Y}$ & $\mathbf{P}$ \\
\hline $\begin{array}{l}\text { Riot Control Burning Pit } \\
\text { (RCP) }\end{array}$ & $\mathrm{P}$ & $\mathrm{P}$ & $\mathrm{P}$ & $\mathrm{P}$ & $\mathrm{Y}$ & $\mathrm{P}$ \\
\hline Prototype Building (PB) & $Y$ & - & - & $P$ & $\mathrm{P}$ & $\mathrm{P}$ \\
\hline $\begin{array}{l}\text { South Beach Trench } \\
\text { (SBT) }\end{array}$ & $\mathrm{P}$ & - & - & - & - & - \\
\hline $\begin{array}{l}\text { South Beach Demolition } \\
\text { (SBDG) }\end{array}$ & - & - & $P$ & $\mathrm{P}$ & $\mathrm{P}$ & - \\
\hline $\begin{array}{l}\text { Robins Point Demolition } \\
\text { Ground (RPDG) }\end{array}$ & $\mathrm{P}$ & $\mathrm{P}$ & - & $P$ & $P$ & $\mathrm{P}$ \\
\hline $\begin{array}{l}\text { Robins Point Tower Site } \\
\text { (RPTS) }\end{array}$ & $\mathrm{P}$ & - & - & - & $P$ & - \\
\hline
\end{tabular}

a A hyphen indicates that the medium is not of concern/potential concern.

\subsubsection{White Phosphorus Burning Pits}

Soil and groundwater are also media of concern at the WPP AOC. In addition, offshore sediments are of potential concern. This conclusion is based on the shore erosion occurring in the area (Weston 1992) and the observed elevated concentrations of metals and TOX in unfiltered water samples only (USGS 1991). Any surface water in the area is also a medium of potential concern. However, there are no marshes nearby, so marsh sediments and water are not media of potential concern. The atmosphere is a medium of potential concern because of the possibility of contaminated windborne fugitive dust originating at the site, elevated soil-gas contamination, and the reported odor of the chemical agent $\mathrm{CN}$ in the area (Nemeth 1989; Weston 1992).

\subsubsection{Riot Control Burning Pit}

Existing data indicate that groundwater is the only medium of concern at the RCP AOC. Soils, surface water, and sediments, both in the nearby marsh and offshore, are media 
of potential concern, as is the atmosphere. The potential concern for soils and the atmosphere stems from the elevated soil-gas contamination, possible contaminated fugitive dust, and site history. The potential concern for sediments is based on the shore erosion in the area (Weston 1992), the potential for surface runoff, and the site history.

\subsubsection{Prototype Building}

Soil is the only medium of concern at the PB AOC. Groundwater and any surface water at the site are media of potential concern. The potential concern for groundwater is based on possible leaching of soils at the site and the proximity of the site to areas with contaminated groundwater. The potential concern for the atmosphere is based on the possibility of windborne contaminated dust leaving the PB site.

\subsubsection{South Beach Trench}

No media of concern have been identified at the SBT AOC. The presence of a few munitions fragments in the trench, the lack of any disposal history, and the low level of chlordane $(0.053 \mathrm{ppm})$ in a soil sample taken at the site (Nemeth 1989; Sonntag 1991) indicate that soil is a medium of potential concern.

\subsubsection{South Beach Demolition Ground}

No media of concern have been identified at the SBDG AOC. Groundwater, offshore sediments, and water are media of potential concern. This potential concern is based on the past use of the site for HE munitions disposal in holes and the extensive erosion that has placed the site offshore in Chesapeake Bay covered with sand (Nemeth 1989; Sonntag 1991).

\subsubsection{Robins Point Demolition Ground}

No media of concern have been identified at the RPDG AOC. The site history indicates that soils and possibly surface water, sediments, and groundwater in and under the nearby marsh are media of potential concern. (The absence of explosives or metals in the few soil samples collected from the site [Nemeth 1989] is believed to be an insufficient reason to exclude soils and other media as of potential concern.) The atmosphere is also a medium of potential concern because of the possible occurrence of windborne contaminated fugitive dust.

\subsubsection{Robins Point Tower Site}

No media of concern have been identified at the RPTS AOC. Soil and groundwater are the only media of potential concern. This categorization is based on the lack of information regarding the use of the site for material disposal. The site was used as an observation and launch site for rocket testing. A test burn of material, mainly. wood 
contaminated with radioactivity, was planned for the site in 1959 but may not have occurred (Nemeth 1989).

\subsubsection{Contaminants of Potential Concern}

At each J-Field site, contaminants of potential concern are those that have been detected in samples at concentrations significantly above background, or that could reasonably be expected (on the basis of site history or use) to be present in significant quantities. Tables 3.7 and 3.8 summarize the contaminants of potential concern identified for the J-Field sites. Each table is divided into two sections. The first section lists contaminants of potential concern based on sampling data for each environmental medium; the second section gives contaminants of potential concern based on site history and use. Entries in the second section are not associated with specific environmental media because they are not based on sampling data. Surface water data are not included in the tables because relatively few contaminants were found. Where contaminants have been found in surface water, the contaminants of potential concern are the subset of volatile organics listed under the "groundwater" heading in Table 3.7.

The information in the tables can be combined with a conceptual model for each site to determine the potential contaminants of concern for each environmental medium. For example, each contaminant listed in the soil-gas column would be expected, on the basis of site geohydrology, to be a contaminant of potential concern both for soil and groundwater. The table entries are discussed by site in the following sections.

\subsubsection{Toxic Burning Pits}

Analytical data show the presence of many contaminants of potential concern in the TBP AOC. Extensive plumes of soil gas contaminated with chlorinated solvents, aromatics, alkanes, and other organic materials that apparently originated from the TBP have been detected. Soil samples show high concentrations (up to 2.6\%) of lead and lower concentrations of other metals. Low concentrations of VOCs (including TRCLE) were found, as were PCBs and some pesticides. However, it is reported that the pesticide measurements may represent "false positives" (Nemeth 1989). The trace amounts of BNAs detected in the soil do not justify listing them as contaminants of potential concern.

Analyses of standing water samples from the TBP AOC show lead and possibly mercury as contaminants of potential concern. Groundwater data show that many VOCs are present at sufficiently high concentrations to be contaminants of potential concern. Several of them, such as 12DCE, TRCLE, and vinyl chloride, are present at concentrations well above the federal MCL values. Metals, such as lead and arsenic, and nitrate are also present at concentrations above federal MCLs. Cyanide is also present. Mustard degradation products (up to $21 \mu \mathrm{g} / \mathrm{L}$ thiodiglycol) and explosives (up to $213 \mu \mathrm{g} / \mathrm{L}$ nitrocellulose) have been found in 
TABLE 3.7 Preliminary Identification of Contaminants of Potential Concern for the Toxic Burning Pits at J-Field ${ }^{\mathrm{a}}$

Based on Analytical Data

\begin{tabular}{llll}
\hline Soil Gas & Soil & Groundwater & \\
Trichloroethylene & Arsenic & Arsenic & Ethyl benzene \\
Tetrachloroethylene & Cadmium & Nickel (?) & Toluene \\
Dichloroethylene & Chromium (?) & Lead & Chloroform \\
Trichloroethanes & Lead & Selenium & Carbon tetrachloride \\
Alkanes & Mercury & Zinc & $1,1,2-$ Trichloroethane \\
Phthalates & Zinc & Nitrate & 1,1,2,2,-Tetrachloroethane \\
Heavy aromatics & Trichloroethylene & Cyanide & Vinyl chloride \\
& Petroleum hydrocarbons & Sulfate & 1,1-Dichloroethylene \\
& PCBs & PETN & tr-1,2-Dichloroethylene \\
& Heptachlor epoxide & Nitrocellulose & Trichloroethylene \\
& Other VOCs & RDX & Tetrachloroethylene \\
& Other pesticides & Nitrobenzene & Sulfone \\
& & Cesium-137 & 1,4-Dithiane \\
& & Strontium-90 & 1,4-Oxithiane \\
& & Benzene & Thiodiglycol \\
\hline
\end{tabular}

Based on Site History

\begin{tabular}{ll} 
CWAs & Degradation products of CWAs \\
VX & HE munitions \\
Mustard & Explosive-related compounds \\
G-agents & Chlorinated solvents \\
Incapacitating agents (CS, CN) & Smoke munitions (FS, FM) \\
\hline
\end{tabular}

a A question mark indicates status uncertain.

b G-agents are the nerve agents GA (O-ethyl-N,N-dimethylphosphoramidacyanidate [tabun]), GB (isopropyl methylphosphonofluoridate [sarin]), GD (pinacolyl methylphosphonofluoridate [soman]), and GF (cyclohexyl methylphosphonofluoridate).

some of the wells near the pits. The radioactive species cesium-137 and strontium-90 are listed as contaminants of potential concern because elevated concentrations (up to $172 \mathrm{pCi} / \mathrm{L}$ ) were found in three wells (P3, JF51, and JF73) (USGS 1991).

The site history indicates the potential presence of additional contaminants for which sufficient analytical data are not available. These contaminants include CWAs such as VX, G-agents, mustard, and incapacitating and smoke agents, as well as CWA degradation products (Tables 3.7 and 3.8). Although most of the CWAs disposed of at J-Field are expected to be degraded by now, they are included as contaminants of potential concern because of their extreme toxicity and their possible presence in UXO. 
TABLE 3.8 Preliminary Identification of Contaminants of Potential Concern at the White Phosphorus Burning Pits and Other J-Field Sites ${ }^{\mathrm{a}}$

Part I: White Phosphorus Burning Pits

Based on Analytical Data

\begin{tabular}{|c|c|c|}
\hline Soil Gas & Soil & Groundwater \\
\hline $\begin{array}{l}\text { Trichloroethylene } \\
\text { Tetrachloroethylene } \\
\text { Simple aromatics } \\
\text { Other hydrocarbons }\end{array}$ & $\begin{array}{l}\text { Barium } \\
\text { Chromium } \\
\text { Lead } \\
\text { Zinc } \\
\text { Nitrate } \\
\text { Petroleum hydrocarbons } \\
\text { Aromatics (?) } \\
\text { Cyanide }\end{array}$ & $\begin{array}{l}\text { Nitrate } \\
\text { Cyanide } \\
\text { Dinitrotoluene } \\
\text { Nitrocellulose } \\
\text { RDX } \\
\text { 1,3-Dithiane } \\
\text { Thiodiglycol } \\
\text { 4-Chlorophenyl } \\
\text { methylsulfoxide } \\
\text { Trichloroethylene }\end{array}$ \\
\hline \multicolumn{3}{|c|}{ Based on Site History } \\
\hline $\begin{array}{l}\text { White phosphorus } \\
\text { White phosphorus munitions }\end{array}$ & \multicolumn{2}{|c|}{ Other chemicals (small amounts) } \\
\hline
\end{tabular}

Part II: Other Sites ${ }^{b}$

Based on Analytical Data

\begin{tabular}{lll}
\hline Soil Gas & Soil & Groundwater \\
& & \\
Heavy aromatics (RCP) & Lead (RCP, PB) & Zinc ? (SBT, RPTS) \\
$\begin{array}{l}\text { Phthalates (RCP) } \\
\text { DCE or TCE and TRCLE or } \\
\text { TCLEE (RCP) }\end{array}$ & Cadmium (PB) & Cyanide (RCP, RPDG) \\
& DDD, DDE, DDT (PB) & Benzene (RCP, PB) \\
& Chethyl isobutyl \\
& & ketone (RCP, PB) \\
& & Trichloroethane (RPTS) \\
\hline
\end{tabular}

Based on Site History

$\mathrm{CS}, \mathrm{CN}, \mathrm{DM}$, riot control

HE, sensitive chemicals, CK ?, agents (RCP)

HE munitions (PB, SBDG) radium and strontium-90? (RPDG, RPTS)

a A question mark indicates status uncertain.

b Codes in parentheses indicate sites involved: RCP = Riot Control Burning Pit, PB = Prototype Building, SBT = South Beach Trench, RPTS = Robins Point Tower Site, RPDG = Robins Point Demolition Ground, SBDG = South Beach Demolition Ground. 


\subsubsection{White Phosphorus Burning Pits}

Soil-gas data for the WPP AOC show the presence of some VOCs (such as TRCLE and TCLEE) and some aromatics. Soil data show the presence of metals, with lead concentrations up to $2,960 \mathrm{ppm}$. Other contaminants of potential concern found at the WPP include petroleum hydrocarbons, nitrate, cyanide, and possibly aromatic hydrocarbons. Total phosphorus was found to be elevated, and because the analytical data do not include the form of the measured phosphorus, the possibility that an appreciable fraction is present as WP must be considered. Lead and possibly sulfate are considered surface water contaminants of potential concern on the basis of analytical data for samples of standing water collected from the pits.

Groundwater data show that nitrate, cyanide, some explosives-related compounds, some mustard degradation products, and TRCLE are contaminants of potential concern. Existing data do not indicate the presence of PCBs or pesticides in the groundwater.

The site history indicates that WP munitions and other forms of WP may have been disposed of at the WPP AOC; therefore, WP is a contaminant of potential concern. WP may be present either in pure form or as PWP.

\subsubsection{Riot Control Burning Pit}

Because of soil-gas analysis results, heavy aromatics, phthalates, and some chlorinated solvents (DCE or TCE and TRCLE or TCLEE) are considered contaminants of concern at the RCP. Soil data show that lead and possibly chromium are contaminants of potential concern. Insufficient data exist regarding organic materials as contaminants of potential concern in soil at the site.

Groundwater data indicate that cyanide, benzene, and methyl isobutyl ketone (MIBK) are contaminants of potential concern. Insufficient data exist to determine if VOCs and other organic compounds, including CWAs and CWA degradation products, are contaminants of potential concern.

The site history indicates that riot control agents such as adamsite (DM), chloroacetophenone (CN), and especially o-chlorobenzylidene malononitrile (CS) are contaminants of potential concern.

\subsubsection{Prototype Building}

Passive soil-gas studies indicate minor organic contamination in discrete areas east of the PB AOC. Soil data indicate that lead, cadmium, and pesticides (and their breakdown products, such as DDD, DDE, and DDT) are also contaminants of potential concern. Benzene and MIBK are contaminants of potential concern in groundwater. The site history suggests that explosives and contaminants in unspecified wastes, including the contents of the four drums presently on the site (Weston 1992), may be contaminants of potential concern. 


\subsubsection{South Beach Trench}

No data exist on soil-gas contamination at the SBT AOC. On the basis of one surface soil sample, chlordane is a contaminant of potential concern. Sampling data from one monitoring well ( $\mathrm{TH} 10$ ) indicate that zinc may be a contaminant of potential concern in the groundwater. Insufficient data are available to determine if other organic compounds or metals are contaminants of potential concern in either the soil or groundwater at the site.

Information on the site history and use is lacking. The presence of a few munitions fragments on the site (Nemeth 1989) is insufficient to suggest contaminants of potential concern.

\subsubsection{South Beach Demolition Area}

Existing environmental data are insufficient to indicate any contaminants of potential concern at the SBDG AOC. In any case, most of the site is currently offshore and covered with sand. The site history of HE munitions demolition indicates that metals and explosives may be contaminants of potential concern.

\subsubsection{Robins Point Demolition Ground}

Existing environmental media (surface soil and surface water) sampling data do not support the listing of any contaminants of potential concern for the RPDG AOC; however, the site history indicates that explosives and possibly cyanide may be contaminants of potential concern. An item filled with cyanogen chloride (CK) was reportedly destroyed at the site, and cyanide is a degradation product of $\mathrm{CK}$.

\subsubsection{Robins Point Tower Site}

No sampling data exist on which to base the listing of contaminants of potential concern for soil gas or soil for the RPTS AOC. Groundwater data from two wells (TH11 and JF1) indicate that zinc and 111TCE may be contaminants of potential concern. Site history and use indicate it is possible that rocket fuel components and the radioactive species radium and strontium-90 may be contaminants of potential concern. The radioactive species could be present if the once-planned test burn of radioactively contaminated wood was actually conducted at the site.

\subsubsection{Present and Probable Future Land Use}

Current use of J-Field is limited to one OB area and two OD areas. These areas are operating under RCRA interim status. One area, a pan located about $50 \mathrm{~m}$ west of the PB, is planned to be used to burn small amounts of propellants or explosives. One OD area is 
the RPDG, used to detonate munitions. The other area, near the WPP, is used for emergency detonation of items containing WP.

It is currently anticipated that $\mathrm{OB} / \mathrm{OD}$ activities will continue at the three areas now in use. The levels of activities were reported in January 1991 to be one or two emergency disposal operations per year at the WPP AOC and about 100 days of operations per year at the RPDG AOC (ICF-Kaiser Engineers 1991). In addition, it is possible that non-RCRApermitted flashing of small quantities of explosives will be conducted at J-Field. These activities may include flashing of small amounts of explosives left in opened and cleaned shell casings. These actions are needed to certify that the casings are " $5 \mathrm{X}$ " clean. No CWAs will be disposed of at J-Field (Benioff 1992).

Hunting and trapping are not allowed at J-Field. Seasonal hunting of migratory birds is permitted along the entire shore of J-Field (Wrobel 1994). Areas of the Gunpowder River and Chesapeake Bay near J-Field are used for fishing from boats (ICF-Kaiser Engineers 1991). Access to the shore is prohibited.

\subsubsection{Potential Exposure Pathways}

The determination of preliminary remediation goals (PRGs) requires examination of potential exposure pathways and selection of those pathways most likely to result in exposure either to humans or to biota in the environment. Potential pathways of contaminant migration for each AOC have been discussed in Section 2.3.

\subsubsection{Preliminary Remediation Goals}

PRGs for each environmental medium of concern and each site at J-Field are, in essence, preliminary estimates of cleanup levels that should be attained by conducting remedial actions. For surface water and groundwater, PRGs can be chosen to be based on ARARs. Commonly used ARARs consist of federal MCLs, nonzero maximum contaminant level goals (MCLGs), state water quality standards (SWQSs), and federal water quality criteria (FWQC). The choice among these values depends on the ultimate receptor, the availability of the chosen ARAR for the contaminant of concern, and similar factors. For example, for water that is a current or potential source of drinking water, FWQC may have to be used for those parameters for which no MCL, nonzero MCLG, or SWQS are available (EPA 1991a). For pathways for which aquatic life in the marshes or estuaries is the ultimate receptor, freshwater or marine criteria can be used as cleanup levels.

Surface water and groundwater ARARs applicable to the J-Field contaminants of potential concern, except CWAs and CWA degradation products are summarized in Table 3.9. Some available data for CWAs and CWA degradation products are provided in Table 3.10. As indicated by the tables, very few water pathways criteria are available for many 
TABLE 3.9 Federal Water Quality Criteria, Standards, and Guidelines for Contaminants of Potential Concern at J-Field ${ }^{\mathrm{a}}$

\begin{tabular}{|c|c|c|c|c|c|c|c|c|c|}
\hline \multirow[b]{5}{*}{ Parameter } & \multirow[b]{5}{*}{ MCL } & \multicolumn{8}{|c|}{ Concentrations ( $\mu \mathrm{g} / \mathrm{L}$, except as noted) } \\
\hline & & \multicolumn{4}{|c|}{ Human Health } & & & & \\
\hline & & \multicolumn{2}{|c|}{ Water Ingestion } & \multicolumn{2}{|c|}{ Fish Ingestion } & \multicolumn{4}{|c|}{ Aquatic Life } \\
\hline & & \multirow{2}{*}{$\begin{array}{c}\text { Threshold } \\
\text { Toxicity } \\
\text { Protection }\end{array}$} & \multirow{2}{*}{$\begin{array}{c}10^{-6} \\
\text { Cancer } \\
\text { Risk }\end{array}$} & \multirow{2}{*}{$\begin{array}{l}\text { Threshold } \\
\text { Toxicity } \\
\text { Protection }\end{array}$} & \multirow{2}{*}{$\begin{array}{c}10^{-6} \\
\text { Cancer } \\
\text { Risk }\end{array}$} & \multicolumn{2}{|c|}{ Freshwater } & \multicolumn{2}{|c|}{ Marine } \\
\hline & & & & & & Acute & Chronic & Acute & Chronic \\
\hline \multicolumn{10}{|c|}{ Metals and Inorganic Compounds } \\
\hline Arsenic & 50 & $-{ }^{b}$ & 0.025 & - & 0.0175 & $\begin{array}{l}850(\mathrm{~V})^{\mathbf{c}} \\
360(\mathrm{III})\end{array}$ & $\begin{array}{l}48(V)^{c} \\
190(I I I)\end{array}$ & $\begin{array}{l}2,319(\mathrm{~V})^{\mathrm{C}} \\
69(\mathrm{III})\end{array}$ & $\begin{array}{l}13(\mathrm{~V})^{\mathrm{c}} \\
36(\mathrm{III})\end{array}$ \\
\hline Barium & 1,000 & - & - & - & - & - & - & - & - \\
\hline Cadmium & 10 & 10 & - & - & - & $3.9^{\mathrm{d}}$ & $1.1^{\mathrm{d}}$ & 43 & \\
\hline Chromium & 50 & $\begin{array}{l}50(\mathrm{VI}) \\
179,000 \text { (III) }\end{array}$ & - & $\overline{3.4} \times 10^{6}(\mathrm{III})$ & - & $\begin{array}{l}16(\mathrm{VI}) \\
1,700(\mathrm{III})^{\mathrm{d}} \\
210(\mathrm{III})^{\mathrm{d}}\end{array}$ & $11(\mathrm{VI})$ & $\begin{array}{l}1,100(\mathrm{VI}) \\
10,300(\mathrm{III})^{\mathrm{c}}\end{array}$ & $50(\mathrm{VI})$ \\
\hline Lead & 50 & 50 & - & 50 & - & $82^{\mathrm{d}}$ & $3.2^{\mathrm{d}}$ & 140 & 5.6 \\
\hline Mercury & 2 & 10 & - & 0.146 & - & 2.4 & 0.012 & 2.1 & 0.025 \\
\hline Nickel & - & 15.4 & - & 100 & - & $1,800^{d}$ & $96^{d}$ & 140 & 7.1 \\
\hline Selenium & 10 & 10 & - & - & - & 260 & 35 & 410 & 54 \\
\hline Zinc & $5,000^{e}$ & 5,000 & - & - & - & $320^{\mathrm{d}}$ & 47 & 170 & 58 \\
\hline Cyanide & 200 & 200 & - & - & - & 22 & 5.2 & 1 & 1 \\
\hline Nitrate (as N) & 10,000 & - & - & - & - & - & - & - & - \\
\hline Sulfate & $250,000^{\ominus}$ & 一 & - & - & - & - & - & - & - \\
\hline \multicolumn{10}{|c|}{ Volatile Organic Compounds } \\
\hline Carbon tetrachloride & 5 & - & 0.42 & - & 6.94 & $35,200^{c}$ & - & $50,000^{c}$ & - \\
\hline Chloroform & 100 & - & 0.19 & - & 15.7 & $28,900^{c}$ & $1,240^{\mathrm{C}}$ & - & - \\
\hline Ethyl benzene & 700 & 2,400 & - & 3,280 & - & $32,000^{c}$ & - & $430^{c}$ & - \\
\hline 1,1-Dichloroethylene & 7 & - & 0.033 & - & 1.85 & $11,600^{\mathrm{c}}$ & - & $224,000^{c}$ & - \\
\hline
\end{tabular}


Concentrations ( $\mu \mathrm{g} / \mathrm{L}$, except as noted)

\begin{tabular}{|c|c|c|c|c|c|c|c|c|c|}
\hline \multirow[b]{4}{*}{ Parameter } & \multirow[b]{4}{*}{ MCL } & \multicolumn{4}{|c|}{ Human Health } & & & & \\
\hline & & \multicolumn{2}{|c|}{ Water Ingestion } & \multicolumn{2}{|c|}{ Fish Ingestion } & \multicolumn{4}{|c|}{ Aquatic Life } \\
\hline & & \multirow{2}{*}{$\begin{array}{l}\text { Threshold } \\
\text { Toxicity } \\
\text { Protection }\end{array}$} & \multirow{2}{*}{$\begin{array}{c}10^{-6} \\
\text { Cancer } \\
\text { Risk }\end{array}$} & \multirow{2}{*}{$\begin{array}{l}\text { Threshold } \\
\text { Toxicity } \\
\text { Protection }\end{array}$} & \multirow{2}{*}{$\begin{array}{c}10^{-6} \\
\text { Cancer } \\
\text { Risk }\end{array}$} & \multicolumn{2}{|c|}{ Freshwater } & \multicolumn{2}{|c|}{ Marine } \\
\hline & & & & & & Acute & Chronic & Acute & Chronic \\
\hline \multicolumn{10}{|c|}{ Volatile Organic Compounds (Cont.) } \\
\hline 1,1-Dichloroethylene & 7 & - & 0.033 & - & 1.85 & $11,600^{\mathrm{c}}$ & - & $224,000^{c}$ & - \\
\hline Toluene & 1,000 & 15,000 & - & 424,000 & - & $17,500^{\mathrm{c}}$ & - & $6,300^{c}$ & $5,000^{c}$ \\
\hline Methylisobutylketone & - & - & - & - & - & - & - & - & - \\
\hline 112TCE & 5 & - & 0.60 & - & 41.8 & - & $9,400^{c}$ & - & - \\
\hline $12 \mathrm{DCE}$ & $\begin{array}{l}70 \text { (cis) } \\
100 \text { (trans) }\end{array}$ & - & - & - & - & 11,600 & - & 224,000 & - \\
\hline Vinyl chloride & 2 & - & 2 & - & 525 & - & - & - & - \\
\hline TRCLE & 5 & - & 2.8 & 一 & 80.7 & $45,000^{c}$ & $21,900^{c}$ & 2,000 & - \\
\hline TCLEA & - & - & 0.17 & - & 10.7 & - & $2,400^{c}$ & $9,020^{c}$ & - \\
\hline TCLEE & 5 & - & 0.88 & - & 8.85 & $5,280^{c}$ & $840^{c}$ & $10,000^{c}$ & $450^{c}$ \\
\hline Benzene & 5 & - & 0.67 & - & 40 & $5,300^{c}$ & - & $5,100^{c}$ & $700^{c}$ \\
\hline Monochlorobenzene & 100 & 488 & - & - & - & $250^{\mathrm{c}}$ & $60^{c}$ & $160^{c}$ & $129^{c}$ \\
\hline \multicolumn{10}{|c|}{ Semivolatile Organic Compounds } \\
\hline PAHs & - & - & 0.0031 & - & 0.031 & - & - & $300^{c}$ & - \\
\hline Phthalates & - & - & - & - & - & $940^{c}$ & $3^{c}$ & 2,944 & $3.4^{\mathrm{c}}$ \\
\hline PEHs & - & - & - & - & - & - & - & - & - \\
\hline Pesticides, PCBs & & & & & & & & & \\
\hline Chlordane & 2 & - & 0.022 & - & 0.00048 & 2.4 & 0.0043 & 0.09 & 0.004 \\
\hline Heptachlor & 0.4 & - & 0.011 & - & 0.00029 & 0.528 & 0.003 & 0.053 & 0.0036 \\
\hline Heptachlorepoxide & 0.2 & - & - & - & 0.00029 & - & - & - & - \\
\hline DDD & - & - & - & - & - & - & - & - & - \\
\hline $\mathrm{DDE}$ & - & - & - & - & - & $1,050^{c}$ & - & $14^{c}$ & - \\
\hline DDT & - & - & 0.0012 & - & 0.000024 & 1.1 & 0.001 & 0.13 & 0.001 \\
\hline PCBs & 0.5 & - & 0.013 & - & 0.000079 & 2.0 & 0.014 & 10 & 0.03 \\
\hline
\end{tabular}


TABLE 3.9 (Cont.)

\begin{tabular}{|c|c|c|c|c|c|c|c|c|c|}
\hline \multirow[b]{5}{*}{ Parameter } & \multirow[b]{5}{*}{ MCL } & \multicolumn{8}{|c|}{ Concentrations ( $\mu \mathrm{g} / \mathrm{L}$, except as noted) } \\
\hline & & \multicolumn{4}{|c|}{ Human Health } & & & & \\
\hline & & \multicolumn{2}{|c|}{ Water Ingestion } & \multicolumn{2}{|c|}{ Fish Ingestion } & \multicolumn{4}{|c|}{ Aquatic Life } \\
\hline & & \multirow{2}{*}{$\begin{array}{l}\text { Threshold } \\
\text { Toxicity } \\
\text { Protection }\end{array}$} & \multirow{2}{*}{$\begin{array}{c}10^{-6} \\
\text { Cancer } \\
\text { Risk }\end{array}$} & \multirow{2}{*}{$\begin{array}{l}\text { Threshold } \\
\text { Toxicity } \\
\text { Protection }\end{array}$} & \multirow{2}{*}{$\begin{array}{c}10^{-6} \\
\text { Cancer } \\
\text { Risk }\end{array}$} & \multicolumn{2}{|c|}{ Freshwater } & \multicolumn{2}{|c|}{ Marine } \\
\hline & & & & & & Acute & Chronic & Acute & Chronic \\
\hline \multicolumn{10}{|c|}{ Explosives-Related Compounds } \\
\hline 2,4-Dinitrotoluene & - & - & $0.05^{f}$ & - & 9.1 & $330^{c, g}$ & $230^{c, g}$ & $590^{\mathrm{c}, \mathrm{g}}$ & $370^{\mathrm{c}, \mathrm{g}}$ \\
\hline 2,6-Dinitrotoluene & - & - & $0.05^{f}$ & - & - & - & - & - & - \\
\hline TNT & - & $2^{f}$ & - & - & - & - & 一 & - & - \\
\hline $\mathrm{HMD}$ & & $400^{f}$ & - & - & - & - & - & - & 一 \\
\hline RDX & - & $2^{\mathrm{f}}$ & - & - & - & - & - & - & - \\
\hline 1,3,5-Trinitrobenzene & - & - & - & - & - & - & - & - & - \\
\hline 1,3-Dinitrobenzene & - & $1^{f}$ & - & - & - & - & - & - & - \\
\hline Nitrobenzene & - & 19,800 & - & - & - & $27,000^{c}$ & - & $6,680^{c}$ & - \\
\hline Nitroglycerin & & $5^{f}$ & - & - & - & - & - & - & - \\
\hline Nitrocellulose & - & Nontoxic & - & - & - & - & - & - & - \\
\hline $\begin{array}{l}\text { Pentaerythritol- } \\
\text { tetranitrate }\end{array}$ & 一 & - & - & 一 & - & - & 一 & - & 一 \\
\hline Tetrazene & - & - & - & - & - & - & - & - & - \\
\hline $\begin{array}{l}\text { 2,4,6-Trintroben- } \\
\text { zaldehyde }\end{array}$ & - & 一 & - & - & - & - & - & - & 一 \\
\hline Tetryl & - & - & - & - & - & - & - & - & - \\
\hline $\begin{array}{l}\text { 2,4,6-Trinitrophenyl } \\
\text { methylnitramine }\end{array}$ & - & - & - & - & - & 一 & 一 & - & - \\
\hline \multicolumn{10}{|l|}{ Other ${ }^{h}$} \\
\hline Thiodiglycol & - & - & - & - & - & $8.2 \times 10^{7}, i$ & - & $6.8 \times 10^{5}, i$ & - \\
\hline VX & - & - & 一 & - & - & $0.3^{\mathrm{i}}$ & - & $0.3^{i}$ & - \\
\hline 1,4-Dithiane & - & - & - & - & - & $1.2 \times 10^{5}$ & - & $26,500^{i}$ & - \\
\hline White phosphorus & - & $0.1^{f}$ & - & - & - & - & - & - & - \\
\hline $\begin{array}{l}\text { Diisopropyl methyl- } \\
\text { phosphonate }\end{array}$ & - & $600^{f}$ & - & - & - & - & - & - & - \\
\hline
\end{tabular}

See footnotes on next page. 


\section{TABLE 3.9 (Cont.)}

a In the body of the table, roman numerals in parentheses represent the valence state of the element.

b Value not available.

c Insufficient data to develop criteria. Value given is lowest observed effect level.

d Hardness-dependent criteria, value is for $100 \mathrm{mg} / \mathrm{L}$.

e Secondary MCL.

f Lifetime health advisory for adults or $10^{-6}$ cancer risk (EPA 1992c).

$g$ Reported value is for dinitrotoluene, isomer unspecified.

h Only those CWAs and degradation products are listed for which water quality data are available.

i $96 \mathrm{H}-\mathrm{LC}_{60}$ values $-50 \%$ of organisms will die in $96 \mathrm{~h}$ (ICF-Kaiser Engineers 1994).

Source: EPA (1986) unless otherwise specified. 
TABLE 3.10 Atmospheric Criteria for Chemical Warfare Agents That Are Contaminants of Potential Concern at J-Field

\begin{tabular}{|c|c|c|}
\hline \multirow[b]{2}{*}{ Chemical Warfare Agent } & \multicolumn{2}{|c|}{ Recommended Exposure Limit ${ }^{\mathrm{a}}\left(\mathrm{mg} / \mathrm{m}^{3}\right)$} \\
\hline & $\begin{array}{c}\text { Time-Weighted } \\
\text { Average }\end{array}$ & $\begin{array}{l}\text { Immediately } \\
\text { Dangerous to Life } \\
\text { and Health }\end{array}$ \\
\hline \multicolumn{3}{|l|}{ Lethal Chemical Agents } \\
\hline $\begin{array}{l}\text { Tabun (GA) } \\
\text { Sarin (GB) } \\
\text { Soman (GD) } \\
\text { VX } \\
\text { Mustard (H, HD, HT) } \\
\text { Lewisite (L) }\end{array}$ & $\begin{array}{r}0.0001 \\
0.00003 \\
0.00001 \\
0.003 \\
0.0001^{\mathrm{c}}\end{array}$ & $\begin{array}{r}-\overline{2} \\
0 . \\
\overline{2} \\
0.4 \\
0.5 \\
-\end{array}$ \\
\hline \multicolumn{3}{|l|}{ Incapacitating Agents } \\
\hline $\begin{array}{l}\text { Adamsite (DM) } \\
\text { Chloroacetophenone (CN) } \\
\text { o-Chlorobenzylidene malonitrile (CS) } \\
\text { 3-Quinuclidinyl benzilate (BZ) }\end{array}$ & $\begin{array}{r}- \\
- \\
0.004\end{array}$ & $\begin{array}{l}- \\
- \\
-\end{array}$ \\
\hline \multicolumn{3}{|l|}{ Blood Agents } \\
\hline Cyanogen chloride (CK) & - & - \\
\hline \multicolumn{3}{|l|}{ Smoke/Incendiary Agents } \\
\hline $\begin{array}{l}\text { Titanium tetrachloride (FM) } \\
\text { Sulfur trioxide-chlorosulfonic acid (FS) } \\
\text { White phosphorus (WP) }\end{array}$ & $\overline{-}$ & $\overline{-}$ \\
\hline
\end{tabular}

a As recommended by the Surgeon General for the work place.

b Not applicable.

c Value is a ceiling.

Source: Weston (1992).

explosives-related compounds, CWAs, and CWA degradation products. Atmospheric criteria for CWAs, given in Table 3.10, can be used for atmospheric pathways for workers, which were selected for baseline risk assessment by ICF-Kaiser Engineers (1991).

Chemical-specific ARARs for soils, which are needed to establish cleanup levels, are generally not available (EPA 1991a). The water quality criteria and other standards can be used to develop soil cleanup levels. However, this procedure requires model calculations for each exposure pathway considered. For groundwater pathways to the marshes or estuaries, the model evaluates the contaminant moving down through the vadose zone, entering and mixing with groundwater, being transported to the point of discharge, and mixing with marsh 
or estuary water at the discharge point. For each step, a transfer or dilution factor is determined by the model. Use of these model calculations gives soil cleanup levels as concentrations that will result in water concentrations at or below the selected criteria for the site, exposure pathway, and chemical parameter considered. Similar types of transfer factors or dilutions are needed for the surface water and air pathways.

The information currently available for J-Field is not sufficient to carry out model calculations to estimate soil cleanup levels. In addition, very little information is available on which to base an estimate of the significance of the different exposure pathways. Such is especially the case for CWAs, for which very little data are available. Therefore, the use of even very simplified model equations requiring estimates for transfer and dilution factors as inputs would result in such crude estimates as to be potentially misleading and useless. For these reasons, preliminary estimates will not be given here of the soil cleanup levels for contaminants of concern for each of the sites at J-Field. It is expected that the collection of additional data will enable such estimates to be made. 


\section{REMEDIAL INVESTIGATION TASKS}

This section details the specific tasks to be undertaken in the remedial investigation of J-Field, including project planning, community relations planning, field investigation, sample analysis and validation, data evaluation, risk assessment, and report preparation. The current schedules for specific tasks associated with the RI field investigation, FFS, FS, and ERA are presented in Appendix D.

\subsection{PROJECT PLANNING}

The project planning phase involves the initial preparatory work done to outline the scope of the project. The following activities have already been initiated regarding the environmental investigation of J-Field: (1) meetings between representatives from APG, the USGS, the AEC (formerly USATHAMA), and ANL; (2) ANL analysis of data gathered during previous site investigations at J-Field; (3) development of a CERCLA Section 120 Federal Facility Agreement between the U.S. Army and EPA outlining tasks for the remedial investigation of a number of study areas at APG; (4) identification of data requirements; and (5) preliminary development of this RI Work Plan, which documents the scoping process and delineates future tasks. This document provides a history of the site and an evaluation of the areas that will be investigated during the RI. It also outlines project management organization and presents a schedule for completion of the various tasks.

\subsection{PLAN PREPARATION AND INTERFACE WITH ONGOING STUDIES}

This RI Work Plan is the document that coordinates the various task plans required to complete the RI. The Sampling and Analysis Plan (SAP) is the overarching document in that it details procedures for the collection of field samples and the laboratory analysis of environmental media and biota from the various disposal locations at J-Field. The SAP consists of two volumes: the FSP (Volume 1) and the QAPjP (Volume 2). The FSP addresses the sampling needs for the first phase of the RI and ERA. Procedures for ensuring data quality are detailed in the QAPjP. The ERA Work Plan addresses the collection and analysis of biota. ANL is also developing a Health and Safety Plan (HSP) covering site activities undertaken by ANL employees. The ANL contractor will prepare an HSP covering those field activities conducted by the contractor. ANL will be responsible for final approval of the contractor HSP.

ANL's investigative effort will incorporate information to be generated by the implementation of Phase 2 of the USGS Work Plan, sediment sampling/analysis to be conducted by APG/EPA, and a removal to be performed by an APG/COE contractor, Roy F. Weston, Inc. 


\subsection{COMMUNITY RELATIONS}

The APG has an established Community Relations Plan (CRP); a separate CRP will not be prepared for this RI. The APG will provide the personnel, materials, and service support needed to assist EPA in undertaking a community relations program. The existing CRP will be used as the operating document regarding base contact with outside communities.

\subsection{FIELD INVESTIGATION}

Other than the field activities of USGS, EPA/APG, COE, and Weston, ANL will oversee the execution of field activities specifically related to the implementation of this work plan and ensure that such actions are consistent with the procedures delineated in the SAP. ANL personnel will conduct field sampling of ecological specimens. Contractor personnel will install groundwater monitoring wells (if needed) and collect samples from site groundwater, surface water, and soil media. ANL, in conjunction with APG, will install a tidal monitoring gage off Robins Point in the Chesapeake Bay.

\subsection{SAMPLE ANALYSIS AND VALIDATION}

ANL will ensure that data collection and sample analyses are consistent with the procedures for data quality assurance outlined in the FSP and QAPjP. Data will be managed by ANL and APG under the USATHAMA Installation Restoration Data Management System (IRDMS), a computerized database. The contractor analytical laboratory will develop data validation procedures consistent with $\mathrm{QAPjP}$ requirements and with the reporting format of IRDMS.

The IRDMS, a controlled AEC system for entry, storage, and retrieval of data, is used in support of Army Installation Restoration Program (IRP) projects. Specific instructions for format, coding, and data submission are described in the current IRDMS users' guide (USATHAMA 1987).

Numerical results from the contractor laboratory will be reported in terms of the contaminant concentration in the environmental samples. Sample results will remain unadjusted before entry into IRDMS. Only laboratory data collected under the QAPjPdesignated protocols for calibration and quality control will be submitted to IRDMS. Uncorrected values less than the certified reporting limits specified in the QAPJP for each contaminant will not be reported. Data correction factors are maintained in separate files in the IRDMS.

Three levels of data are recognized in the IRDMS. Level 1 consists of the data generated by the contractor laboratory. The contractor laboratory will transfer error-free laboratory sample data files to the IRDMS at least weekly. The IRDMS will process each file through an internal contractor-compatible error-checking program to verify acceptance. 
When files fail this error check, the contractor laboratory will be required to review and correct the data and retransmit the files.

Accepted files will be sent into the IRDMS as Level 2 files. Level 2 files are protected by write keys and cannot be modified by the contractor laboratory. The files can be read by the contractor laboratory upon approval by the data managers. Level 2 files are the responsibility of AEC until after approximately 10 working days, when the data are loaded into the APG installation database. Data in the installation database are considered Level 3 data, and the contractor laboratory can only access these data with AEC-supplied report programs and read codes. These files are also protected from changes by write keys.

The contractor laboratory will be responsible for the accuracy of all data submitted to the IRDMS and shall ensure that all data in the system correspond exactly to the data contained on the original laboratory entry logs. The verification of data accuracy with the IRDMS Commanding Officer shall be accomplished within five working days following the transfer of files from Level 1 to Level 2.

\subsection{DATA EVALUATION}

Sample data will be evaluated according to the protocols established in the QAPJP and the Quality Assurance Program Plan developed.for the Edgewood Area investigations. ANL will compile the results of field investigations and laboratory analyses and will summarize the relationship between the concentrations of chemicals in each site medium, the potential human and/or environmental receptors of contamination, and the potential transfer pathways and environmental fate of contaminants.

\subsection{RISK ASSESSMENT}

ANL will perform an ERA as described in the ERA Work Plan, previously described in Section 3.2.2.2. ICF-Kaiser Engineers, Inc. (AEC contractor), will conduct a BRA to evaluate the risks to receptor populations posed by the site in the absence of any remedial activities. The risk assessment will be based on the evaluated data and will involve four distinct subtasks: (1) identification of the contaminants of concern, (2) delineation of the actual or potential exposure pathways and receptor populations and determination of the extent of exposure, (3) assessment of the toxicity of each contaminant of concern according to established guidelines, and (4) integration of the data in subtasks 1-3 to characterize the current or potential risks posed by the site to human health and the environment. The risk assessment will also identify remaining data uncertainties and/or the limits of exposure assumptions.

\subsection{REPORT PREPARATION}

ANL will prepare a monthly progress and financial report for APG regarding J-Field activities. The monthly report will summarize the status of work and the dates specific tasks 
were performed, the percentage of work completed relative to the project schedule, difficulties encountered and corrective actions taken, current activities, activities scheduled for the next reporting period, any changes in project management, and a projection of expenditures needed to complete the project. At the conclusion of the scheduled tasks, ANL will prepare and submit a draft RI report (with supporting data included as appendices) to APG for submittal to the EPA and the MDE. After comments to the draft RI are received, ANL will prepare a draft final RI for further regulatory review. Finally, ANL will prepare a final RI report. The current schedule for the preparation and submittal of RI reports (RI Work Plan, FSP, QAPjP, HSP, and RI report) is provided in Appendix D. 


\section{PROJECT MANAGEMENT}

This section presents the overall technical approach, objectives, reporting, organizational structure, and staffing for implementation of the J-Field RI. The project schedule and associated reporting milestones have been summarized in Section 4 .

This RI Work Plan is the first in a series of work plans and reports that will complete a planned RI/FS of J-Field. Companion documents to the RI Work Plan include a SAP (FSP and QAPjP), an ERA Work Plan, and an HSP. The results of the investigative efforts proposed in the RI will be documented in an RI report.

The information gathered during the RI will be used to support the performance of both an FFS (for the Toxic Burning Pits AOC) and an FS. The FS Work Plan will be prepared and submitted according to the generalized schedule presented in Appendix D. It is anticipated that the FS Work Plan will incorporate the information gathered during the RI, the FFS, and other ongoing investigations.

\subsection{TECHNICAL APPROACH}

The technical approach employed for the J-Field RI Work Plan is based on the need to incorporate the environmental monitoring data collected from past studies and the data being generated by ongoing studies into an overall strategy to complete the investigation and, if necessary, carry out remediation of J-Field. The following key features characterize ANL's approach:

- Apply a flexible, "streamlined" or "observational approach" to the RI/FS process as a general framework,

- Give full consideration to archival data in characterizing the environmental setting and contaminated environmental media at the site,

- Whenever possible, use field screening of contaminants to focus subsequent laboratory analyses, and

- Perform sampling and analysis to characterize the site with data of sufficient quality to meet desired DQOs. 


\subsection{OBJECTIVES}

The objectives of the RI Work Plan for J-Field are as follows:

- Delineate the vertical and horizontal extent of soil contamination in J-Field soils, surface water, and, if necessary, estuarine sediment;

- Delineate the areal and vertical extent of groundwater contamination;

- Identify and characterize the potential contamination sources;

- Gather data of sufficient quality to evaluate remediation alternatives; and

- Gather data of sufficient quality to support a risk assessment and, if necessary, treatability studies.

\subsection{REPORTING}

ANL will present the results of the RI effort in three principal types of documents: technical updates, monthly progress reports, and the RI report.

\subsubsection{Technical Updates}

ANL will prepare technical updates for work conducted in AOCs at J-Field. These documents will summarize the results of initial site characterization activities such as field screening results. The technical updates will also describe action items planned, including any modifications to field sampling plans suggested by initial field screening efforts and/or other investigative efforts (by EPA, USGS, Weston, etc.), in order to better focus any investigative efforts.

\subsubsection{Monthly Progress Reports}

By the 15th of each month, ANL will prepare a monthly report that summarizes the activities of the previous month. The monthly reports will include a project description, a planned schedule of obligation of funds, and an actual schedule of obligation of funds. The monthly reports will also include a description of accomplishments during the reporting period.

\subsubsection{RI Report}

The RI report will summarize the results of all field work conducted. The report will describe the procedures, methods, and results of field investigations and will include the information generated on the type and extent of contamination, contamination sources and 
migration pathways, and the actual and potential receptors. The form of the RI report will follow the guidelines provided in Guidance for Conducting Remedial Investigations and Feasibility Studies under CERCLA, Interim Final (EPA 1988).

\subsection{ORGANIZATION}

The proposed project organization is depicted in Figure 5.1. The ANL program managers and project manager will form the ANL program management team. John Ditmars and Andrew Anderson will be the ANL program managers. They will be authorized to commit ANL's resources to accomplish the project objectives and will represent ANL in all contractual matters with APG. The program managers will ultimately be responsible for all contractual matters and for ANL and subcontractor performance.

The ANL project manager, Louis Martino, will report directly to the ANL program managers. He will be responsible for the day-to-day direction and management of ANL's field, laboratory, and office activities related to the APG project and will oversee the activities of ANL's subcontractors. He will coordinate and integrate the activities of other investigators working directly under the control of the APG project officer, including (but not limited to) the USGS, Weston, the EPA, and ICF-Kaiser Engineers, Inc. Martino will be authorized to procure necessary support services and equipment on behalf of APG, and subject to APG approval, to implement the work plan. He will also be responsible for staffing, scheduling, and reporting all ANL activities.

The ANL project manager will be supported by staff and leaders of the RI team, the FS/FFS team, and an ANL contracting officer, contract technical representative (CTR), and several subcontractors. An environmental chemistry coordinator (ECC) will be responsible for coordinating the collection, CWA screening, and analyses of all samples during the RI. The ECC will also serve as a liaison between the project QA officer (QAO) and the project manager. The RI team leader will be responsible for conducting the RI and preparing the RI report. The RI team leader will also be responsible for ensuring that sampling and analyses deemed necessary by the ecological assessment team are performed during the RI. The ecological assessment team will implement the ERA Work Plan. The FFS/FS team leaders will be responsible for the FFS and the FS (including ensuring that the RI results in characterization data that meet relevant DQOs) and for the preparation of the FFS and FS reports.

The ANL project $\mathrm{QAO}$ will be responsible for all aspects of $\mathrm{QA} / \mathrm{QC}$ related to the work plan. The QAO will serve as a liaison between the ANL project manager and the APG program QAO, all subcontractors, and contract laboratories. The ANL project QAO will report directly to the ANL program managers when corrective action is required as a result of system and performance audits. 


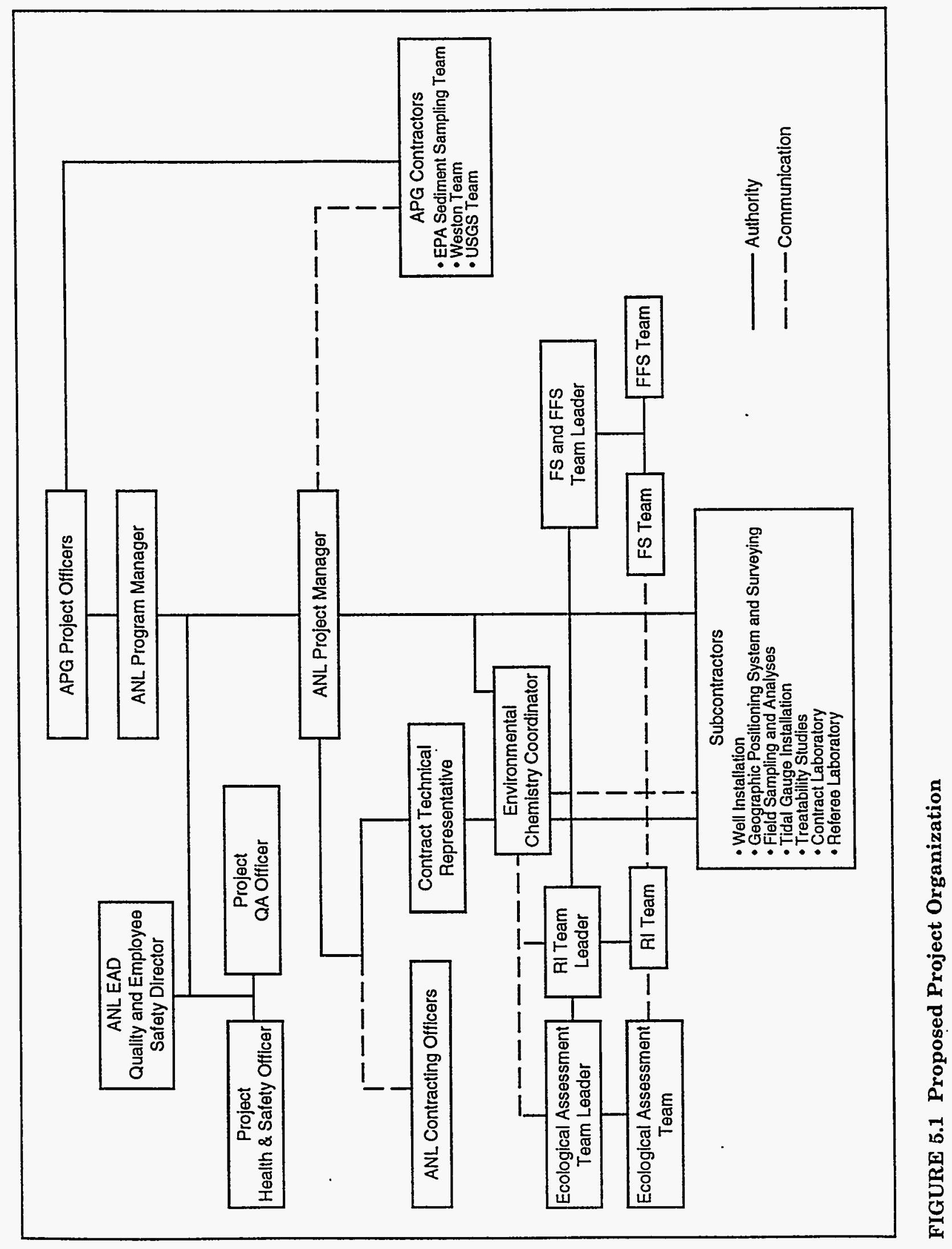


A designated ANL staff member will be authorized by the ANL contracting officer to function as the project CTR. The CTR will be responsible for directing and monitoring the activities of all ANL subcontractors. The CTR will be the primary liaison between the ANL contractors and the project manager.

The ANL project health and safety officer (HSO) will be responsible for all health and safety aspects related to the work plan. The HSO will serve as a liaison between the ANL project manager, related safety officers within APG, and the health and safety officers of all subcontractors. The HSO will report to the ANL contracting officer should corrective action be required of an ANL subcontractor. The HSO will also report to the ANL program manager should corrective action be required for activities conducted by ANL staff members. 


\section{REFERENCES}

Benioff, P., 1992, memo to file, Argonne National Laboratory, Argonne, Ill., June 2.

Benioff, P., et al., 1995, Remedial Investigation Sampling and Analysis Plan for J-Field, Aberdeen Proving Ground, Maryland, Volume 1: Field Sampling Plan, ANL/EAD/TM-38, Vol. 1, Argonne National Laboratory, Argonne, Ill., March.

Biang, C., et al., 1995, Work Plan for Focused Feasibility Study of the Toxic Burning Pits Area at J-Field, Aberdeen Proving Ground, Maryland, ANL/EAD/TM-39, Argonne National Laboratory, Argonne, Ill., March.

COE - see U.S. Army Corps of Engineers.

Durda, J., et al., 1992, Risk and Biological Impact Assessment at U.S. Army Aberdeen Proving Ground; Technical Plan Volume I, Draft Final, APO4IQCDF37, ICF-Kaiser Engineers, Abingdon, Md.

EPA - see U.S. Environmental Protection Agency.

Framework for Ecological Risk Assessment, EPA/630/R-92/001, Risk Assessment Forum, Washington, D.C.).

Hughes, W.B., 1992, letter with attachment from Hughes (U.S. Geological Survey, Towson, Md.) to J. Wrobel (U.S. Army, Aberdeen Proving Ground, Md.), June 19.

Hughes, W.B., 1993, Hydrogeology and Soil-Gas at J-Field, Aberdeen Proving Ground, Maryland, U.S. Geological Survey, Water-Resources Investigations Report 92-4087, prepared in cooperation with the U.S. Army, Aberdeen Proving Ground Support Activity, Environmental Management Division, Towson, Md.

ICF-Kaiser Engineers, 1991, Baseline Risk Assessment for Eight Selected Study Areas at Aberdeen Proving Ground, Task Order 11, prepared for U.S. Army Corps of Engineers, Toxic and Hazardous Materials Agency, Jan.

ICF-Kaiser Engineers, 1994, Comparison of Chemical Concentrations at Selected Sites at J-Field with Risk-Based Concentrations, draft report, submitted to U.S. Army Environmental Center, Aberdeen Proving Ground Installation Restoration Risk Assessment Support, Feb.

Mazelon, M., 1993, Letter from Mazelon (Chief Engineer, Roy F. Weston, Inc., Aberdeen Proving Ground, Md.) to R. Rizzieri (U.S. Army Corps of Engineers, Aberdeen Proving Ground, Md.), Feb. 26. 
Nemeth, G., 1989, RCRA Facility Assessment, Edgewood Area, Aberdeen Proving Ground, $M D, 39-26-0490-90$, U.S. Army Environmental Hygiene Agency, Waste Disposal Engineering Division, Aberdeen Proving Ground, Md., Nov.

Prasad, S., et al., 1995, Remedial Investigation Sampling and Analysis Plan for J-Field, Aberdeen Proving Ground, Maryland, Volume 2: Quality Assurance Project Plan, ANL/EAD/TM-38, Vol. 2, Argonne National Laboratory, Argonne, Ml., March.

Princeton Aqua Science, 1984, Munitions Disposal Study, prepared for Directorate of Engineering and Housing, Environmental Management Office, Department of the Army, Aberdeen Proving Ground, Md., Nov.

Sonntag, W., 1991, Sampling and Analysis Plan for the Investigation of Ground-Water Contamination at J-Field, Aberdeen Proving Ground, Maryland, Draft Report, U.S. Geological Survey, Reston, Va.

U.S. Army, 1965, aerial photograph of Edgewood Area, roll no. G\&O 85047, frame nos. 8-1 to 8-2 and 9-1 to 9-4, Environmental Hygiene Agency, Aberdeen Proving Ground, Md.

U.S. Army Corps of Engineers, 1923, "Gunpowder Neck Maryland, Grid Zone A," Terrain Map 26547531/46, War Department, U.S. Army, Washington, D.C.

U.S. Army Toxic and Hazardous Materials Agency, 1987, Installation Restoration Data Management User's Guide - Version 86.6, U.S. Army Armament, Munitions, and Chemical Command, Scientific Computer Center, Aberdeen Proving Ground, Md.

USATHAMA - see U.S. Army Toxic and Hazardous Materials Agency.

U.S. Environmental Protection Agency, 1986, Quality Criteria for Water 1986, EPA 440/5-86/001, Office of Water Regulation and Standards, Washington, D.C., May.

U.S. Environmental Protection Agency, 1987, Data Quality Objectives for Remedial Response Activities Development Process, EPA/540/6-87/003, Office of Emergency and Remedial Response and Office of Waste Programs Enforcement, Washington, D.C., March.

U.S. Environmental Protection Agency, 1988, Guidance for Conducting Remedial Investigations and Feasibility Studies under CERCLA, Interim Final, EPA/540/G-89/004, Office of Emergency and Remedial Response, Washington, D.C., Oct.

U.S. Environmental Protection Agency, 1989, Risk Assessment Guidance for Superfund: Volume I-Human Health Evaluation Manual (Part A), EPA/540/1-89/003, Office of Emergency and Remedial Response, Washington, D.C.

U.S. Environmental Protection Agency, 1991a, Risk Assessment Guidance for Superfund: Volume I - Human Health Evaluation Manual (Part B, Development of Risk-Based Preliminary Remediation Goals), Interim, 9285.7-01B, Office of Emergency and Remedial Response, Washington, D.C., Dec. 
U.S. Environmental Protection Agency, 1991b, Risk Assessment Guidance for Superfund: Volume I-Human Health Evaluation Manual (Part C, Risk Evaluation of Remedial Alternatives), EPA/540/R-92/004, Office of Research and Development, Washington, D.C.

U.S. Environmental Protection Agency, 1992a, unpublished data.

U.S. Environmental Protection Agency, 1992b, Drinking Water Regulations and Health Advisories, Office of Water, Washington, D.C., April.

U.S. Environment Protection Agency, 1992c, Framework for Ecological Risk Assessment, EPA/630/R-92/001, Risk Assessment Forum, Washington, D.C.

U.S. Environmental Protection Agency and U.S. Department of the Army, 1990, Federal Facility Agreement, Aberdeen Proving Ground, Administration Docket No. III-FCA-CERC-004, March.

U.S. Geological Survey, 1991, Phase II Workplan and Field Sampling Plan Update for the Remedial Investigation at J-Field Aberdeen Proving Ground, Maryland, prepared by Water Resources Division, Towson, Md., for the U.S. Army, Aberdeen Proving Ground Support Activity, Environmental Management Division, May.

U.S. Geological Survey, 1992, unpublished data.

USGS - see U.S. Geological Survey.

Weston, 1992, Characterization and Interim Remediation of J-Field at Edgewood Area Aberdeen Proving Ground, Maryland, Draft Report, Roy F. Weston, Inc., for U.S. Army Corps of Engineers, Baltimore District, Feb.

Wrobel, J., 1994, personal communication from Wrobel (Directorate of Safety, Health, and Environment, U.S. Army, Aberdeen Proving Ground, Md.) to J. Quinn (Environmental Assessment Division, Argonne National Laboratory, Argonne, Mll.), Aug. 23. 


\section{LIST OF PREPARERS}

This Remedial Investigation Work Plan was prepared for the U.S. Army Directorate of Safety, Health, and Environment by the Environmental Assessment Division of ANL. The following ANL staff have contributed to the preparation of this work plan.

\begin{tabular}{|c|c|c|}
\hline Name & Education/Experience & Contribution \\
\hline Louis Martino & $\begin{array}{l}\text { M.S., environmental toxicology; } \\
15 \text { years experience in environmental } \\
\text { assessment; J-Field project manager. }\end{array}$ & $\begin{array}{l}\text { Section } 1 \text { Introduction } \\
\text { Section } 2 \text { Site Setting and } \\
\text { Background } \\
\text { Section } 4 \text { Remedial Investigation } \\
\text { Tasks }\end{array}$ \\
\hline Paul Benioff & $\begin{array}{l}\text { Ph.D., nuclear chemistry; } 17 \text { years } \\
\text { experience in theoretical chemistry; } \\
16 \text { years experience in environmental } \\
\text { assessment; lead author. }\end{array}$ & $\begin{array}{l}\text { Section } 2 \text { Site Setting and } \\
\text { Background } \\
\text { Section } 3 \text { Work Plan Rationale }\end{array}$ \\
\hline Randall Biang & $\begin{array}{l}\text { M.S., geology; } 11 \text { years experience in } \\
\text { groundwater and hazardous waste } \\
\text { investigations. }\end{array}$ & $\begin{array}{l}\text { Section } 2 \text { Site Setting and } \\
\text { Background } \\
\text { Section } 4 \text { Remedial Investigation } \\
\text { Tasks }\end{array}$ \\
\hline David Dolak & $\begin{array}{l}\text { M.S., environmental science; } 10 \text { years } \\
\text { experience in environmental } \\
\text { assessment including sample } \\
\text { collection and laboratory analysis. }\end{array}$ & $\begin{array}{l}\text { Section } 4 \text { Remedial Investigation } \\
\text { Tasks }\end{array}$ \\
\hline $\begin{array}{l}\text { Christopher } \\
\text { Dunn }\end{array}$ & $\begin{array}{l}\text { Ph.D., plant ecology; } 13 \text { years } \\
\text { experience in ecological research and } \\
\text { assessment. }\end{array}$ & $\begin{array}{l}\text { Section } 2 \text { Site Setting and } \\
\text { Background }\end{array}$ \\
\hline $\begin{array}{l}\text { Rebecca } \\
\text { Haffenden }\end{array}$ & $\begin{array}{l}\text { J.D., } 5 \text { years experience in } \\
\text { environmental law, specializing in } \\
\text { RCRA and CERCLA; } 10 \text { years } \\
\text { experience in energy: law. }\end{array}$ & Section 3 Work Plan Rationale \\
\hline Terri Patton & $\begin{array}{l}\text { M.S., geology; } 6 \text { years experience in } \\
\text { radiochemical analysis; } 5 \text { years } \\
\text { experience in environmental } \\
\text { assessment. }\end{array}$ & $\begin{array}{l}\text { Section } 1 \text { Introduction } \\
\text { Section } 2 \text { Site Setting and } \\
\text { Background } \\
\text { Section } 5 \text { Project Management }\end{array}$ \\
\hline Yug-Yea Wang & $\begin{array}{l}\text { Ph.D., civil engineering/environ- } \\
\text { mental engineering; } 10 \text { years } \\
\text { experience in environmental research; } \\
2 \text { years experience in environmental } \\
\text { assessment. }\end{array}$ & $\begin{array}{l}\text { Section } 4 \text { Remedial Investigation } \\
\text { Tasks }\end{array}$ \\
\hline
\end{tabular}




\begin{tabular}{clc}
\hline Name & \multicolumn{1}{c}{ Education/Experience } & \multicolumn{1}{c}{ Contribution } \\
\hline Cheong-Yip Yuen & $\begin{array}{l}\text { Ph.D., geology (hydrogeology and } \\
\text { environmental geology); 6 years } \\
\text { experience in hydrogeological } \\
\text { analysis; 12 years experience in } \\
\text { process geomorphology. }\end{array}$ & $\begin{array}{c}\text { Section 2 Site Setting and } \\
\text { Background } \\
\text { Section 3 Work Plan Rationale }\end{array}$ \\
\hline
\end{tabular}


A-1

\section{APPENDIX A:}

SUMMMARY OF EPA ANALYTICAL LEVELS 


\section{APPENDIX A:}

\section{SUMMARY OF EPA ANALYTICAL LEVELS}

The EPA (1987) has defined five different analytical levels appropriate to sample analyses for use in remedial activities conducted pursuant to RCRA and CERCLA. Table A.1 summarizes information on these analytical levels.

Level I consists of field screening or analyses with portable instruments. Results, which are available in real time, are often neither compound-specific nor quantitative. These methods cost less than those of any other level.

Level II consists of field analyses with portable analytical instruments, which are often set up in a mobile laboratory in the field. The data quality, which can vary widely, depends on the use of suitable calibration standards, reference materials, sample preparation equipment, and operator training. Results are available in real-time or with a delay of several hours.

Level III analyses are all carried out in an off-site laboratory that may or may not be an EPA CLP laboratory. Procedures used may or may not be those stipulated under the CLP, but validation and documentation procedures required in Level IV CLP analyses usually are not used.

Level IV analyses are all CLP routine analytical services. They are performed in a CLP laboratory with CLP protocols. The level is characterized by rigorous QA/QC protocols and documentation.

Level $\mathrm{V}$ analyses are those carried out by nonstandard methods. The analyses are conducted in an off-site laboratory that may or may not be a CLP laboratory. Analytical method development or modification may be required for specific constituents or detection limits.

\section{REFERENCE}

U.S. Environmental Protection Agency, 1987, Data Quality Objectives for Remedial Response Activities Development Process, EPA/540/6-87/003, Office of Emergency and Remedial Response and Office of Waste Programs Enforcement, Washington, D.C., March. 
TABLE A.1 Summary of EPA Analytical Levels Appropriate to Specific Data Uses ${ }^{\text {a }}$

\begin{tabular}{|c|c|c|c|c|}
\hline $\begin{array}{l}\text { Analytical } \\
\text { Level }\end{array}$ & Type of Analysis & Limitations & Data Quality & Data Uses \\
\hline$I$ & $\begin{array}{l}\text { Total organic/inorganic vapor } \\
\text { detection using portable } \\
\text { instruments } \\
\text { Field test kits }\end{array}$ & $\begin{array}{l}\text { Instruments respond to } \\
\text { naturally occurring } \\
\text { compounds }\end{array}$ & $\begin{array}{l}\text { Can provide indication } \\
\text { of contamination if } \\
\text { instruments calibrated } \\
\text { and data interpreted } \\
\text { correctly }\end{array}$ & $\begin{array}{l}\text { Site characterization, } \\
\text { monitoring during } \\
\text { implementation }\end{array}$ \\
\hline II & $\begin{array}{l}\text { Variety of organic compounds by } \\
\text { GC, inorganic compounds by AA, } \\
\text { XRF } \\
\text { Tentative identification } \\
\text { analyte-specific }\end{array}$ & $\begin{array}{l}\text { Tentative identification } \\
\text { Techniques/instruments } \\
\text { limited mostly to volatile } \\
\text { compounds, metals }\end{array}$ & $\begin{array}{l}\text { Dependent on } Q A / Q C \\
\text { steps employed } \\
\text { Data typically reported } \\
\text { in concentration ranges }\end{array}$ & $\begin{array}{l}\text { Site characterization, } \\
\text { evaluation of } \\
\text { alternatives, } \\
\text { engineering design and } \\
\text { monitoring during } \\
\text { implementation }\end{array}$ \\
\hline & $\begin{array}{l}\text { Detection limits vary from low } \\
\text { ppm to low ppb }\end{array}$ & & & \\
\hline III & $\begin{array}{l}\text { Organic and inorganic } \\
\text { compounds using EPA } \\
\text { procedures other than CLP can } \\
\text { be analyte-specific } \\
\text { RCRA characteristic tests }\end{array}$ & $\begin{array}{l}\text { Tentative identification in } \\
\text { some cases } \\
\text { Can provide data of same } \\
\text { quality as level IV }\end{array}$ & $\begin{array}{l}\text { Similar detection limits } \\
\text { to CLP } \\
\text { Less rigorous QAVQC }\end{array}$ & $\begin{array}{l}\text { Risk assessment, PRP } \\
\text { determination, site } \\
\text { characterization, } \\
\text { evaluation of } \\
\text { alternatives, } \\
\text { engineering design, and } \\
\text { monitoring during } \\
\text { implementation }\end{array}$ \\
\hline IV & $\begin{array}{l}\text { HSL organic and inorganic } \\
\text { compounds by GC/MS, AA, ICP } \\
\text { Low ppb detection limit }\end{array}$ & $\begin{array}{l}\text { Tentative identification of } \\
\text { non-HSL parameters } \\
\text { Some time may be required } \\
\text { for validation of packages }\end{array}$ & $\begin{array}{l}\text { Goal is to provide data } \\
\text { of known quality } \\
\text { Rigorous } Q A / Q C\end{array}$ & $\begin{array}{l}\text { Risk assessment, PRP } \\
\text { determination, } \\
\text { evaluation of } \\
\text { alternatives, } \\
\text { engineering design }\end{array}$ \\
\hline
\end{tabular}


TABLE A.1 (Cont.)

\begin{tabular}{clll}
\hline $\begin{array}{c}\text { Analytical } \\
\text { Level }\end{array}$ & \multicolumn{1}{c}{ Type of Analysis } & Limitations & Data Quality \\
\hline$V$ & Nonconventional parameters & $\begin{array}{l}\text { May require method } \\
\text { development or modification } \\
\text { Method-specific detection limits }\end{array}$ & $\begin{array}{l}\text { Mechanism to obtain services } \\
\text { Mechecific } \\
\text { requires special lead time }\end{array}$ \\
\hline Modification of existing methods & $\begin{array}{l}\text { Risk assessment, PRP } \\
\text { determination }\end{array}$
\end{tabular}

a Acronyms: GC = gas chromatography, AA = atomic absorption, XRF = X-ray fluorescence, CLP = Contract Laboratory Program, $\mathrm{PRP}=$ potentially responsible party, HSL = hazardous substance list, $\mathrm{MS}=$ mass spectrometry, ICP $=$ inductively coupled plasma.

Source: EPA (1987). 
A- 6 
$B-1$

APPENDIX B:

IDENTIFICATION OF POTENTIAL AREAS OF CONCERN AT J-FIELD 
B-2 


\section{APPENDIX B:}

\section{IDENTIFICATION OF POTENTIAL AREAS OF CONCERN AT J-FIELD}

\section{B.1 INTRODUCTION}

This appendix describes the methodology used to identify the potential areas of concern (PAOCs) at J-Field, documents the PAOCs on the basis of historical photograph analysis, and reports the results of the PAOC inspections performed April 12-15, 1994, and May 11, 1994.

The methodology used to select the PAOCs is described in Section B.2. The PAOCs are documented and the site inspection results presented in Section B.3. The PAOCs are divided into three groups. One group contains sites that are not associated with the eight AOCs, the second group includes sites associated with the identified AOCs, and the third group includes all craters at J-Field. The PAOCs in the first group could become new AOCs in the future if sampling and analysis indicated contamination were present. The PAOCs in the second group will be.incorporated into their corresponding AOCs for study in the Remedial Investigation. The third group, fieldwide craters, will be addressed in the Ecological Risk Assessment Work Plan.

\section{B.2 METHODOLOGY FOR IDENTIFYING PAOCs}

The PAOCs were designated on the basis of information from two sources: (1) the 1986 RFA (Nemeth 1989), which includes a review of archival information and personnel interviews; and (2) analysis of historical aerial photographs. The photographic analysis involved a brief review of aerial photographs dated 1951, 1957, 1960, 1970, and 1981 (Nemeth 1989) and a detailed analysis of aerial photographs dated 1965 and 1968 (U.S. Army 1965; USGS 1968). The identified PAOCs include areas that show man-made features (such as clearing areas, geometric patterns, and ground scarring), and structures (such as buildings, trenches, storage areas, and roads) on aerial photographs. Their locations are shown in Figure B.1.

The PAOCs identified were inspected in the field April 12-15, 1994, and May 11, 1994. Large-scale (approximately 1 in.:400 ft) aerial photographs from 1965 were used in the field. Features that may reflect previous human activities such as soil piles, metal, and other man-made debris; structure ruins; bomb craters; road tracks; and shallow depressions of regular shape were recorded. The condition of vegetation within and around a PAOC was also documented. On the basis of these features and aerial photographic interpretation, an attempt was made (when possible) to determine the nature of the past activities on each PAOC. 


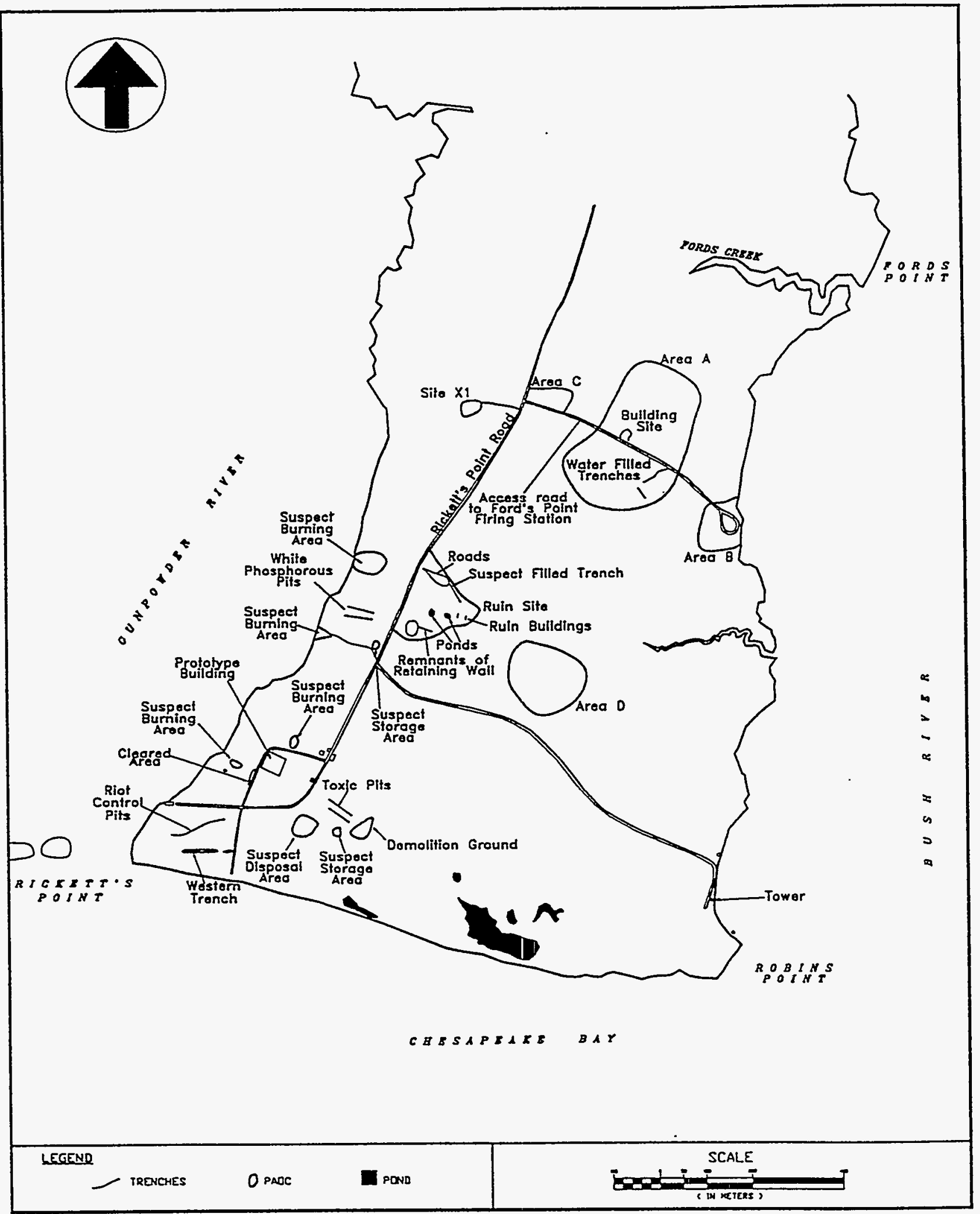

FIGURE B.1 Locations of PAOCs at J-Field 


\section{B.3 FIELD INSPECTION RESULTS}

A total of 17 PAOCs have been inspected. They are Site X1, Areas A to D, two suspected storage areas associated with the Toxic Burning Pits (TBP) area and the White Phosphorous Burning Pits (WPP) area, four suspected burning areas (two near the WPP and two near the Prototype Building), one suspected filled trench (near the South Beach Trench area), one clearing near the southwest corner of the Prototype Building, one suspected disposal area (southwest of the TBP area), the craters of J-Field, one demolition area (southeast of the TBP area), and one ruins site (east of the WPP area). The locations and features of these PAOCs are shown in Figure B.1 and described in the following sections.

For discussion purposes the PAOCs are separated into three groups: those not associated with AOCs (Section B.3.1), those that are (Section B.3.2), and craters (Section B.3.3). Within each group, the PAOCs are described sequentially based on their locations, from north to south.

\section{B.3.1 PAOCs Not Associated with AOCs}

\section{B.3.1.1 Site X1}

Site X1 is in the northwestern part of J-Field, about $300 \mathrm{ft}$ southwest of the intersection of Rickett's Point Road and the access road to the Ford's Point Firing Position. In 1965 aerial photographs, the site was a cleared area with a size of about 120 by $100 \mathrm{ft}$. An access road starting from Rickett's Point Road ended at the site. The access road bed is still discernable in the field today.

The site includes two ruins subsites about $100 \mathrm{ft}$ apart. Collapsed concrete columns are present on the ground at each subsite. Both subsites are surrounded by a ridge of soil piles. The vegetation is much younger within the subsites than in the surrounding areas. A brick wall foundation is visible on the ground in the eastern subsite. A small drum emerges among a soil pile in the western ruin. No bomb craters are found near this site.

Three very shallow depressions with ponded water were identified. All are near the access road. The first shallow depression is about $100 \mathrm{ft}$ from the entrance of the access road and is perpendicular to the road. The second and third depressions are parallel to the access road and are near the first one. Each depression seems to be rectangular and about $6 \mathrm{ft}$ wide. They may represent filled trenches. Site X1 has been present since as early as 1951 (Nemeth 1989). Its use is not known.

\section{B.3.1.2 Area $\mathrm{A}$}

Located in the northern part of J-Field, Area A is characterized by grids of linear features and two water-filled trenches, as they appeared on aerial photographs. The access road to the Ford's Point Firing Station dissects the central part of the site. When inspected 
in the field, the site was swampy. The grid pattern shown on aerial photographs is caused by grids of drainage commonly used to drain wetlands in this region.

One S-shaped trench and one straight trench are present within the drainage grid. The S-shaped trench is located immediately adjacent to the road and is separated from the straight trench by a dirt pile. Both trenches are about 6-7 ft wide. No scrap metal has been found nearby on the ground surface. The past use of the trenches is unclear.

About $400 \mathrm{ft}$ west of the S-shaped trench is an old building site. A small shack appears there in 1965 aerial photographs. The ground now is scattered with a few glass bottles and ceramic sherds. Soil piles surround the site. A prominent, straight, long drainage about $3 \mathrm{ft}$ wide extends from behind the site to the swamp north of J-Field. This drainage is readily noticeable in aerial photographs.

\section{B.3.1.3 Area B (Ford's Point Firing Station)}

Area $B$ is a large open area at the eastern end of an access road in the northern part of J-Field and near the Bush River. It is also referred to Ford's Point Firing Station. Aerial photographs show that the site has existed since as early as 1951 . The site is covered with reed grass (Phragmites). Concrete slabs are piled up near the shore of the Bush River, probably protecting the shore from erosion. Near the southern part of the site a pile of concrete chunks embedded with hollow pipes is present. Soil mounds are present near the western boundary of the site. Two small scrap drums were found on the ground surface near the soil mounds. The past use of the site is not known.

\section{B.3.1.4 Area C}

Area $\mathrm{C}$ is a ruin site near the entrance of the access road to Ford's Point Firing Station. Aerial photographs from 1965 show two buildings near the intersection of the access road and Rickett's Point Road, and a wall near the eastern part of the site. The buildings were destroyed before 1968, as indicated in later aerial photographs. In the field, remnants of a standing concrete wall and bricks are left on the ground surface. Bomb craters are visible near the site. The destroyed buildings probably were used for access control to the Ford's Point Firing Station, while the concrete wall in the eastern part of the site was probably a test site for bombing structures.

\section{B.3.1.5 Ruins Site Across Road from WPP}

A ruins site located across Rickett's Point Road from the WPP includes two building ruins, two connected artificial ponds, four retaining wall structures, and a suspected filled trench. These features are discernable in the 1965 aerial photographs. The western part of the site, where the two building ruins are located, was flooded when the site was inspected. 
The site was used for munitions testing in World War II. Bomb craters are common, especially near the four retaining wall structures. Probably due to bombing, only remnants of buttressed columns and partially destroyed steel-reinforced walls remain in the field. No visible metal scrap has been found on the ground surface. The ruin buildings are in the eastern part of the site. One is a steel-reinforced concrete building, and the other is a steelreinforced brick building. Circular-shaped scars are common on the building's outside walls. Two small ponds connected by a ditch are near the southern part of the site. One of the ponds is rectangular in shape, the other is irregularly shaped. The past use of the ponds is not known.

A suspected filled trench, about 7-8 ft wide, was identified in an area about $80 \mathrm{ft}$ southeast of the ruin buildings. It is partially ponded with water. The suspected filled trench extends southeast for more than $100 \mathrm{ft}$. Traces of road bed are discernable near its end. The roads connect to Rickett's Point Road. A steel tube with a cylinder built inside was found next to a pile of soil between the filled trench and the two building ruins. The past use of the trench is not clear.

A dark-toned area appears in the southwestern part of the site in the 1965 aerial photographs. This area was inspected in the field and was found to be flat and covered with vegetation that is younger than in the surrounding area. No scrap metal was found on the ground surface. The previous use of this area is unknown.

\section{B.3.1.6 Area D}

Area $\mathrm{D}$, located about $400 \mathrm{ft}$ east of the ruins site, is a flooded swamp area. The area has a dark tone in aerial photographs and is dotted with many craters. No road extends to this site. The site probably was used for targeting.

\section{B.3.2 PAOCs Associated with AOCs}

\section{B.3.2.1 Storage Area of WPP}

The suspected storage area, about 30 by $20 \mathrm{ft}$, is in the southeastern corner of the WPP AOC and about $40 \mathrm{ft}$ west of Rickett's Point Road. Some materials are shown on the ground surface in the 1965 aerial photographs. The storage area was observed in the field to be surrounded by piles of soil.

\section{B.3.2.2 Suspected Burning Area near Northwestern Corner of WPP}

This site is in the northwestern corner of the WPP AOC and is covered with reed grass. The 1965 aerial photographs show three suspected burning areas clustered together on this site. Each area was circular in shape, with a diameter about $30 \mathrm{ft}$, and appeared as a dark-toned area in the aerial photographs. Mounds of soil were observed in the field to be 
piled near its northern boundary. A few pieces of scrap metal were scattered nearby. The specific past use of the site is not known.

\section{B.3.2.3 Suspected Burning Area near Southwestern Corner of WPP}

This area appeared as a demolition area in aerial photographs. By the shore of Gunpowder River and at the southwestern corner of the WPP AOC, the area is covered by abundant shells of small arms, grenade caps, 50-caliber shells, and melted glass. Away from the shore, most of the area is covered by reeds (Phragmites). Judging from field observations, this site likely was used for small ammunition demolition.

\section{B.3.2.4 Suspected Burning Area near Northeastern Corner of Prototype Building}

This area appeared in the 1965 aerial photographs as an oval-shaped clearing with three small structures in its western portion. The area is covered with grasses today. The three structures probably were grills. Only one of the structures, with a size of 3 by $3 \mathrm{ft}$, is still in the field. Pieces of silver-like melted metals and charcoals are still visible in the grill. The original clearing area is free from metallic objects. The previous use of the site is unknown.

\section{B.3.2.5 Clearing near Southwestern Corner of Prototype Building}

This area was shown as a clearing in aerial photographs as early as 1951 . No scrap metal was found near the site when it was inspected. There is no evidence to suggest that management or disposal of wastes was carried out at this site.

\section{B.3.2.6 Suspected Burning Area near Southwestern Portion of Prototype Building}

The area appears as a demolition ground in aerial photographs. The site is about $200 \mathrm{ft}$ west of the Prototype Building and near the edge of the woods. Its southern boundary is marked by piles of soil, and its northern boundary is marked by tall reeds and shallow ponded water. Very few trees grow on the site. A rusty empty drum and a belt-shaped piece of scrap metal were found on the ground surface.

\section{B.3.2.7 Western Trench of South Beach Trench Area}

This suspected trench is filled, and it is located about $40 \mathrm{ft}$ west of the current South Beach Trench. In aerial photographs, the western trench is oriented east-west and extends more than $300 \mathrm{ft}$. Some waste was observed in its central and eastern portions. The central 
portion of the trench was once accessible by a road from the south. The filled trench is still discernable in the field. Small drums and cans are scattered in the woods nearby.

\section{B.3.2.8 Storage Area of TBP Area}

Located near the southeastern corner of the TBP area and by the edge of the woods, the storage area is a fenced area about 30 by $30 \mathrm{ft}$. In the 1965 aerial photographs, drums were shown being unloaded from a truck and moved through a track to the storage area. This area probably was used for temporary storage before wastes were disposed in the TBP area.

\section{B.3.2.9 Suspected Disposal Area near Southwestern Portion of TBP Area}

Located in the southwestern portion of the TBP area, this site is shown cleared of nearly all vegetation in late 1950s aerial photographs. In 1965 aerial photographs, soil in the western part of the site is pushed out to the south into the marsh. In the field, the site is covered with reed grass with a few old trees. Near its northern edge, a square pit, about 4 by $4 \mathrm{ft}$ and made of steel, emerges from the ground. The pit is filled with sand. No scrap metals, except for a barbed wire next to an old tree, were seen on the ground surface. The specific use of the site is unknown.

\section{B.3.2.10 Demolition Area near Southeastern Portion of TBP Area}

Documented in the RFA (Nemeth 1989), this site was used for demolition of high-explosive munitions. The site was active in as early as 1965, as seen in aerial photographs. Piles of scrap metals and soils are common on the ground near the site, especially near the marsh.

\section{B.3.3 Craters}

Numerous craters are distributed across J-Field. The craters are visible in largescale historical aerial photographs and in the field. Many of these craters fill with water in the spring.

\section{B.4 REFERENCES}

Nemeth, G., 1989, RCRA Facility Assessment, Edgewood Area, Aberdeen Proving Ground, $M D$, 39-26-0490-90, U.S. Army Environmental Hygiene Agency, Waste Disposal Engineering Division, Aberdeen Proving Ground, Md., Nov. 
U.S. Army, 1965, aerial photograph of Edgewood Area, roll no. G\&O 85047, frame nos. 8-1 to 8-2 and 9-1 to 9-4, Environmental Hygiene Agency, Aberdeen Proving Ground, Md.

USGS - see U.S. Geological Survey.

U.S. Geological Survey, 1968, aerial photographs, roll no. ABB044140000303, frame nos. 118-120, Washington, D.C. 
APPENDIX C:

ANALYTICAL METHODS AND QUANTITATION LIMITS 
TABLE C.1 Target Compound List, Analytical Methods, and Quantitation Limits: Volatile Organic Compounds ${ }^{a}$

\begin{tabular}{|c|c|c|c|c|c|c|}
\hline \multirow[b]{3}{*}{ Analyte } & \multicolumn{3}{|c|}{ Quantitation Limits ${ }^{b}$} & \multirow{2}{*}{\multicolumn{3}{|c|}{ Analytical Method ${ }^{c, d}$}} \\
\hline & \multirow{2}{*}{$\begin{array}{l}\text { Soil/Sediment } \\
\text { ( } \mu \mathrm{g} / \mathrm{g} \text { or } \mathrm{mg} / \mathrm{kg} \text { ) }\end{array}$} & \multirow{2}{*}{$\begin{array}{c}\text { Groundwater } \\
(\mu \mathrm{g} / \mathrm{L})\end{array}$} & \multirow{2}{*}{$\begin{array}{c}\text { Surface Water } \\
(\mu \mathrm{g} / \mathrm{L})\end{array}$} & & & \\
\hline & & & & Soil/Sediment & Groundwater & Surface Water \\
\hline Acetone & 10 & 10 & 10 & $\begin{array}{l}\text { EPA CLP } \\
\text { SOW (OLM01.5) }\end{array}$ & $\begin{array}{l}\text { EPA CLP } \\
\text { SOW (OLM01.5) }\end{array}$ & $\begin{array}{l}\text { EPA CLP } \\
\text { SOW (OLM01.5) }\end{array}$ \\
\hline Benzene & 10 & $5^{\mathrm{e}}$ & 10 & $\begin{array}{l}\text { EPA CLP } \\
\text { SOW (OLM01.5) }\end{array}$ & $\begin{array}{l}\text { EPA } \\
6004-88039\end{array}$ & $\begin{array}{l}\text { EPA CLP } \\
\text { SOW (OLM01.5) }\end{array}$ \\
\hline Bromodichloromethane & 10 & 10 & 10 & $\begin{array}{l}\text { EPA CLP } \\
\text { SOW (OLM01.5) }\end{array}$ & $\begin{array}{l}\text { EPA CLP } \\
\text { SOW (OLM01.5) }\end{array}$ & $\begin{array}{l}\text { EPA CLP } \\
\text { SOW (OLM01.5) }\end{array}$ \\
\hline Bromoform & 10 & 10 & 10 & $\begin{array}{l}\text { EPA CLP } \\
\text { SOW (OLM01.5) }\end{array}$ & $\begin{array}{l}\text { EPA CLP } \\
\text { SOW (OLM01.5) }\end{array}$ & $\begin{array}{l}\text { EPA CLP } \\
\text { SOW (OLM01.5) }\end{array}$ \\
\hline Bromomethane & 10 & 10 & 10 & $\begin{array}{l}\text { EPA CLP } \\
\text { SOW (OLM01.5) }\end{array}$ & $\begin{array}{l}\text { EPA CLP } \\
\text { SOW (OLM01.5) }\end{array}$ & $\begin{array}{l}\text { EPA CLP } \\
\text { SOW (OLM01.5) }\end{array}$ \\
\hline 2-Butanone & 10 & 10 & 10 & $\begin{array}{l}\text { EPA CLP } \\
\text { SOW (OLM01.5) }\end{array}$ & $\begin{array}{l}\text { EPA CLP } \\
\text { SOW (OLM01.5) }\end{array}$ & $\begin{array}{l}\text { EPA CLP } \\
\text { SOW (OLM01.5) }\end{array}$ \\
\hline Carbon disulfide & 10 & 10 & 10 & $\begin{array}{l}\text { EPA CLP } \\
\text { SOW (OLM01.5) }\end{array}$ & $\begin{array}{l}\text { EPA CLP } \\
\text { SOW (OLM01.5) }\end{array}$ & $\begin{array}{l}\text { EPA CLP } \\
\text { SOW (OLM01.5) }\end{array}$ \\
\hline Carbon tetrachloride & 10 & 10 & 10 & $\begin{array}{l}\text { EPA CLP } \\
\text { SOW (OLM01.5) }\end{array}$ & $\begin{array}{l}\text { EPA } \\
6004-88039\end{array}$ & $\begin{array}{l}\text { EPA CLP } \\
\text { SOW (OLM01.5) }\end{array}$ \\
\hline Chlorobenzene & 10 & 10 & 10 & $\begin{array}{l}\text { EPA CLP } \\
\text { SOW (OLM01.5) }\end{array}$ & $\begin{array}{l}\text { EPA CLP } \\
\text { SOW (OLM01.5) }\end{array}$ & $\begin{array}{l}\text { EPA CLP } \\
\text { SOW (OLM01.5) }\end{array}$ \\
\hline Chloroethane & 10 & 10 & 10 & $\begin{array}{l}\text { EPA CLP } \\
\text { SOW (OLM01.5) }\end{array}$ & $\begin{array}{l}\text { EPA CLP } \\
\text { SOW (OLM01.5) }\end{array}$ & $\begin{array}{l}\text { EPA CLP } \\
\text { SOW (OLM01.5) }\end{array}$ \\
\hline Chloroform & 10 & 10 & 10 & $\begin{array}{l}\text { EPA CLP } \\
\text { SOW (OLM01.5) }\end{array}$ & $\begin{array}{l}\text { EPA CLP } \\
\text { SOW (OLM01.5) }\end{array}$ & $\begin{array}{l}\text { EPA CLP } \\
\text { SOW (OLM01.5) }\end{array}$ \\
\hline
\end{tabular}


TABLE C.1 (Cont.)

\begin{tabular}{|c|c|c|c|c|c|c|}
\hline \multirow[b]{3}{*}{ Analyte } & \multicolumn{3}{|c|}{ Quantitation Limits } & \multirow{2}{*}{\multicolumn{3}{|c|}{ Analytical Method ${ }^{c, d}$}} \\
\hline & \multirow{2}{*}{$\begin{array}{c}\text { Soil/Sediment } \\
\text { ( } \mu \mathrm{g} / \mathrm{g} \text { or } \mathrm{mg} / \mathrm{kg})\end{array}$} & \multirow{2}{*}{$\begin{array}{c}\text { Groundwater } \\
(\mu \mathrm{g} / \mathrm{L})\end{array}$} & \multirow{2}{*}{$\begin{array}{c}\text { Surface Water } \\
(\mu \mathrm{g} / \mathrm{L})\end{array}$} & & & \\
\hline & & & & Soil/Sediment & Groundwater & Surface Water \\
\hline Chloromethane & 10 & 10 & 10 & $\begin{array}{l}\text { EPA CLP } \\
\text { SOW (OLM01.5) }\end{array}$ & $\begin{array}{l}\text { EPA CLP } \\
\text { SOW (OLM01.5) }\end{array}$ & $\begin{array}{l}\text { EPA CLP } \\
\text { SOW (OLM01.5) }\end{array}$ \\
\hline Dibromochloromethane & 10 & 10 & 10 & $\begin{array}{l}\text { EPA CLP } \\
\text { SOW (OLM01.5) }\end{array}$ & $\begin{array}{l}\text { EPA CLP } \\
\text { SOW (OLM01.5) }\end{array}$ & $\begin{array}{l}\text { EPA CLP } \\
\text { SOW (OLM01.5) }\end{array}$ \\
\hline 1,1-Dichloroethane & 10 & 10 & 10 & $\begin{array}{l}\text { EPA CLP } \\
\text { SOW (OLM01.5) }\end{array}$ & $\begin{array}{l}\text { EPA CLP } \\
\text { SOW (OLM01.5) }\end{array}$ & $\begin{array}{l}\text { EPA CLP } \\
\text { SOW (OLM01.5) }\end{array}$ \\
\hline 1,2-Dichloroethane & 10 & $5^{\mathrm{e}}$ & 10 & $\begin{array}{l}\text { EPA CLP } \\
\text { SOW (OLM01.5) }\end{array}$ & $\begin{array}{l}\text { EPA } \\
6004-88039\end{array}$ & $\begin{array}{l}\text { EPA CLP } \\
\text { SOW (OLM01.5) }\end{array}$ \\
\hline 1,1-Dichloroethylene & 10 & $5^{\mathrm{e}}$ & 10 & $\begin{array}{l}\text { EPA CLP } \\
\text { SOW (OLMO1.5) }\end{array}$ & $\begin{array}{l}\text { EPA } \\
6004-88039\end{array}$ & $\begin{array}{l}\text { EPA CLP } \\
\text { SOW (OLM01.5) }\end{array}$ \\
\hline $\begin{array}{l}\text { 1,2-Dichloroethylene } \\
\text { (total) }\end{array}$ & 10 & 10 & 10 & $\begin{array}{l}\text { EPA CLP } \\
\text { SOW (OLM01.5) }\end{array}$ & $\begin{array}{l}\text { EPA CLP } \\
\text { SOW (OLM01.5) }\end{array}$ & $\begin{array}{l}\text { EPA CLP } \\
\text { SOW (OLM01.5) }\end{array}$ \\
\hline 1,2-Dichloropropane & 10 & $5^{\mathrm{e}}$ & 10 & $\begin{array}{l}\text { EPA CLP } \\
\text { SOW (OLM01.5) }\end{array}$ & $\begin{array}{l}\text { EPA } \\
6004-88039\end{array}$ & $\begin{array}{l}\text { EPA CLP } \\
\text { SOW (OLM01.5) }\end{array}$ \\
\hline cis-1,3-Dichloropropene & 10 & 10 & 10 & $\begin{array}{l}\text { EPA CLP } \\
\text { SOW (OLM01.5) }\end{array}$ & $\begin{array}{l}\text { EPA CLP } \\
\text { SOW (OLM01.5) }\end{array}$ & $\begin{array}{l}\text { EPA CLP } \\
\text { SOW (OLM01.5) }\end{array}$ \\
\hline trans-1,3-Dichloropropene & 10 & 10 & 10 & $\begin{array}{l}\text { EPA CLP } \\
\text { SOW (OLM01.5) }\end{array}$ & $\begin{array}{l}\text { EPA CLP } \\
\text { SOW (OLM01.5) }\end{array}$ & $\begin{array}{l}\text { EPA CLP } \\
\text { SOW (OLM01.5) }\end{array}$ \\
\hline Ethylbenzene & 10 & 10 & 10 & $\begin{array}{l}\text { EPA CLP } \\
\text { SOW (OLM01.5) }\end{array}$ & $\begin{array}{l}\text { EPA CLP } \\
\text { SOW (OLM01.5) }\end{array}$ & $\begin{array}{l}\text { EPA CLP } \\
\text { SOW (OLM01.5) }\end{array}$ \\
\hline 2-Hexanone & 10 & 10 & 10 & $\begin{array}{l}\text { EPA CLP } \\
\text { SOW (OLM01.5) }\end{array}$ & $\begin{array}{l}\text { EPA CLP } \\
\text { SOW (OLM01.5) }\end{array}$ & $\begin{array}{l}\text { EPA CLP } \\
\text { SOW (OLM01.5) }\end{array}$ \\
\hline
\end{tabular}


TABLE C.1 (Cont.)

\begin{tabular}{|c|c|c|c|c|c|c|}
\hline \multirow[b]{3}{*}{ Analyte } & \multicolumn{3}{|c|}{ Quantitation Limits ${ }^{\mathrm{b}}$} & \multirow{2}{*}{\multicolumn{3}{|c|}{ Analytical Method ${ }^{c, d}$}} \\
\hline & \multirow{2}{*}{$\begin{array}{l}\text { Soil/Sediment } \\
\text { ( } \mu \mathrm{g} / \mathrm{g} \text { or } \mathrm{mg} / \mathrm{kg})\end{array}$} & \multirow{2}{*}{$\begin{array}{c}\text { Groundwater } \\
(\mu \mathrm{g} / \mathrm{L})\end{array}$} & \multirow{2}{*}{$\begin{array}{c}\text { Surface Water } \\
(\mu \mathrm{g} / \mathrm{L})\end{array}$} & & & \\
\hline & & & & Soil/Sediment & Groundwater & Surface Water \\
\hline Methylene chloride & 10 & $5^{e}$ & 10 & $\begin{array}{l}\text { EPA CLP } \\
\text { SOW (OLM01.5) }\end{array}$ & $\begin{array}{l}\text { EPA } \\
6004-88039\end{array}$ & $\begin{array}{l}\text { EPA CLP } \\
\text { SOW (OLM01.5) }\end{array}$ \\
\hline 4-Methyl-2-pentanone & 10 & 10 & 10 & $\begin{array}{l}\text { EPA CLP } \\
\text { SOW (OLM01.5) }\end{array}$ & $\begin{array}{l}\text { EPA CLP } \\
\text { SOW (OLM01.5) }\end{array}$ & $\begin{array}{l}\text { EPA CLP } \\
\text { SOW (OLM01.5) }\end{array}$ \\
\hline Styrene & 10 & 10 & 10 & $\begin{array}{l}\text { EPA CLP } \\
\text { SOW (OLM01.5) }\end{array}$ & $\begin{array}{l}\text { EPA CLP } \\
\text { SOW (OLM01.5) }\end{array}$ & $\begin{array}{l}\text { EPA CLP } \\
\text { SOW (OLM01.5) }\end{array}$ \\
\hline 1,1,2,2-Tetrachloroethane & 10 & 10 & 10 & $\begin{array}{l}\text { EPA CLP } \\
\text { SOW (OLM01.5) }\end{array}$ & $\begin{array}{l}\text { EPA CLP } \\
\text { SOW (OLM01.5) }\end{array}$ & $\begin{array}{l}\text { EPA CLP } \\
\text { SOW (OLM01.5) }\end{array}$ \\
\hline Tetrachloroethylene & 10 & $5^{\ominus}$ & 10 & $\begin{array}{l}\text { EPA CLP } \\
\text { SOW (OLM01.5) }\end{array}$ & $\begin{array}{l}\text { EPA } \\
6004-88039\end{array}$ & $\begin{array}{l}\text { EPA CLP } \\
\text { SOW (OLM01.5) }\end{array}$ \\
\hline Toluene & 10 & 10 & 10 & $\begin{array}{l}\text { EPA CLP } \\
\text { SOW (OLM01.5) }\end{array}$ & $\begin{array}{l}\text { EPA CLP } \\
\text { SOW (OLM01.5) }\end{array}$ & $\begin{array}{l}\text { EPA CLP } \\
\text { SOW (OLM01.5) }\end{array}$ \\
\hline 1,1,1-Trichloroethane & 10 & 10 & 10 & $\begin{array}{l}\text { EPA CLP } \\
\text { SOW (OLM01.5) }\end{array}$ & $\begin{array}{l}\text { EPA CLP } \\
\text { SOW (OLM01.5) }\end{array}$ & $\begin{array}{l}\text { EPA CLP } \\
\text { SOW (OLM01.5) }\end{array}$ \\
\hline 1,1,2-Trichloroethane & 10 & $5^{e}$ & 10 & $\begin{array}{l}\text { EPA CLP } \\
\text { SOW (OLM01.5) }\end{array}$ & $\begin{array}{l}\text { EPA } \\
6004-88039\end{array}$ & $\begin{array}{l}\text { EPA CLP } \\
\text { SOW (OLM01.5) }\end{array}$ \\
\hline Trichloroethylene & 10 & $5^{e}$ & 10 & $\begin{array}{l}\text { EPA CLP } \\
\text { SOW (OLM01.5) }\end{array}$ & $\begin{array}{l}\text { EPA } \\
6004-88039\end{array}$ & $\begin{array}{l}\text { EPA CLP } \\
\text { SOW (OLM01.5) }\end{array}$ \\
\hline Vinyl chloride & 10 & $2^{\mathrm{e}}$ & 10 & $\begin{array}{l}\text { EPA CLP } \\
\text { SOW (OLM01.5) }\end{array}$ & $\begin{array}{l}\text { EPA } \\
6004-88039\end{array}$ & $\begin{array}{l}\text { EPA CLP } \\
\text { SOW (OLM01.5) }\end{array}$ \\
\hline Xylenes (total) & 10 & 10 & 10 & $\begin{array}{l}\text { EPA CLP } \\
\text { SOW (OLM01.5) }\end{array}$ & $\begin{array}{l}\text { EPA CLP } \\
\text { SOW (OLM01.5) }\end{array}$ & $\begin{array}{l}\text { EPA CLP } \\
\text { SOW (OLM01.5) }\end{array}$ \\
\hline
\end{tabular}

See footnotes on next page. 


\section{TABLE C.1 (Cont.)}

a Recommended quantitation limits are equal to the EPA's contract-required quantitation limits (CRQLs), unless otherwise noted. The CRQL is the lowest level that can be reliably achieved within specified limits of precision and accuracy during routine laboratory operating conditions. For the CLP methodologies, the CRQL is determined by the lowest initial calibration standard that is run before the analytical sequence.

b Quantitation limits listed for soil/sediment are based on wet weight. The quantitation limits calculated by the laboratory for soil/sediment are calculated on a dry-weight basis and, therefore, will be higher.

c Source of analytical method Statement of Work (SOW) (OLM01.5) is EPA (1991).

d Source of EPA Method 600 4-88 039 is EPA (1988) (Method 524.2, Measurement of Purgeable Organic Compounds in Water by Capillary Column Gas Chromatography/Mass Spectrometry). Note: Several hardware configurations exist for this method. The referenced values are for the following configurations: wide-bore capillary column, jet separator, and quadrapole mass spectrometer.

e Recommended alternate quantitation limit based on potential human toxicity. 
TABLE C.2 Target Compound List, Analytical Methods, and Quantitation Limits: Semivolatile Organic Compounds ${ }^{a}$

\begin{tabular}{|c|c|c|c|c|c|c|}
\hline \multirow[b]{3}{*}{ Analyte } & \multicolumn{3}{|c|}{ Quantitation Limits $^{\mathrm{b}}$} & \multirow{2}{*}{\multicolumn{3}{|c|}{ Analytical Method ${ }^{d}$}} \\
\hline & \multirow{2}{*}{$\begin{array}{l}\text { Soil/Sediment } \\
(\mu \mathrm{g} / \mathrm{g} \text { or } \mathrm{mg} / \mathrm{kg})\end{array}$} & \multirow{2}{*}{$\begin{array}{c}\text { Groundwater } \\
(\mu \mathrm{g} / \mathrm{L})\end{array}$} & \multirow{2}{*}{$\begin{array}{c}\text { Surface Water } \\
(\mu \mathrm{g} / \mathrm{L})\end{array}$} & & & \\
\hline & & & & Soil/Sediment & Groundwater & Surface Water \\
\hline Acenaphthene & $330 / 150^{e, f}$ & 10 & 10 & $\begin{array}{l}\text { EPA CLP } \\
\text { SOW (OLM01.5) }\end{array}$ & $\begin{array}{l}\text { EPA CLP } \\
\text { SOW (OLM01.5) }\end{array}$ & $\begin{array}{l}\text { EPA CLP } \\
\text { SOW (OLM01.5) }\end{array}$ \\
\hline Acenaphthylene & 330 & 10 & 10 & $\begin{array}{l}\text { EPA CLP } \\
\text { SOW (OLM01.5) }\end{array}$ & $\begin{array}{l}\text { EPA CLP } \\
\text { SOW (OLM01.5) }\end{array}$ & $\begin{array}{l}\text { EPA CLP } \\
\text { SOW (OLM01.5) }\end{array}$ \\
\hline Anthracene & $330 / 50^{\mathrm{e}, \mathrm{f}}$ & 10 & 10 & $\begin{array}{l}\text { EPA CLP } \\
\text { SOW (OLM01.5) }\end{array}$ & $\begin{array}{l}\text { EPA CLP } \\
\text { SOW (OLM01.5) }\end{array}$ & $\begin{array}{l}\text { EPA CLP } \\
\text { SOW (OLM01.5) }\end{array}$ \\
\hline Benz $[a]$ anthracene & $330 / 200^{\theta, f}$ & 10 & 10 & $\begin{array}{l}\text { EPA CLP } \\
\text { SOW (OLM01.5) }\end{array}$ & $\begin{array}{l}\text { EPA CLP } \\
\text { SOW (OLM01.5) }\end{array}$ & $\begin{array}{l}\text { EPA CLP } \\
\text { SOW (OLM01.5) }\end{array}$ \\
\hline Benzo[b]fluoranthene & 330 & 10 & 10 & $\begin{array}{l}\text { EPA CLP } \\
\text { SOW (OLM01.5) }\end{array}$ & $\begin{array}{l}\text { EPA CLP } \\
\text { SOW (OLM01.5) }\end{array}$ & $\begin{array}{l}\text { EPA CLP } \\
\text { SOW (OLM01.5) }\end{array}$ \\
\hline Benzo[k]fluoranthene & 330 & 10 & 10 & $\begin{array}{l}\text { EPA CLP } \\
\text { SOW (OLM01.5) }\end{array}$ & $\begin{array}{l}\text { EPA CLP } \\
\text { SOW (OLM01.5) }\end{array}$ & $\begin{array}{l}\text { EPA CLP } \\
\text { SOW (OLM01.5) }\end{array}$ \\
\hline Benzo[g,h,i]perylene & 330 & 10 & 10 & $\begin{array}{l}\text { EPA CLP } \\
\text { SOW (OLM01.5) }\end{array}$ & $\begin{array}{l}\text { EPA CLP } \\
\text { SOW (OLM01.5) }\end{array}$ & $\begin{array}{l}\text { EPA CLP } \\
\text { SOW (OLM01.5) }\end{array}$ \\
\hline Benzo[a]pyrene & 330 & 10 & 10 & $\begin{array}{l}\text { EPA CLP } \\
\text { SOW (OLM01.5) }\end{array}$ & $\begin{array}{l}\text { EPA CLP } \\
\text { SOW (OLM01.5) }\end{array}$ & $\begin{array}{l}\text { EPA CLP } \\
\text { SOW (OLM01.5) }\end{array}$ \\
\hline 4-Bromophenyl phenyl ether & 330 & 10 & 10 & $\begin{array}{l}\text { EPA CLP } \\
\text { SOW (OLM01.6) }\end{array}$ & $\begin{array}{l}\text { EPA CLP } \\
\text { SOW (OLM01.5) }\end{array}$ & $\begin{array}{l}\text { EPA CLP } \\
\text { SOW (OLMO1.5) }\end{array}$ \\
\hline Butylbenzylphthalate & 330 & 10 & 10 & $\begin{array}{l}\text { EPA CLP } \\
\text { SOW (OLM01.5) }\end{array}$ & $\begin{array}{l}\text { EPA CLP } \\
\text { SOW (OLM01.5) }\end{array}$ & $\begin{array}{l}\text { EPA CLP } \\
\text { SOW (OLM01.5) }\end{array}$ \\
\hline Carbazole & 330 & 10 & 10 & $\begin{array}{l}\text { EPA CLP } \\
\text { SOW (OLM01.5) }\end{array}$ & $\begin{array}{l}\text { EPA CLP } \\
\text { SOW (OLM01.5) }\end{array}$ & $\begin{array}{l}\text { EPA CLP } \\
\text { SOW (OLM01.5) }\end{array}$ \\
\hline 4-Chloroaniline & 330 & 10 & 10 & $\begin{array}{l}\text { EPA CLP } \\
\text { SOW (OLM01.5) }\end{array}$ & $\begin{array}{l}\text { EPA CLP } \\
\text { SOW (OLM01.5) }\end{array}$ & $\begin{array}{l}\text { EPA CLP } \\
\text { SOW (OLM01.5) }\end{array}$ \\
\hline
\end{tabular}


TABLE C.2 (Cont.)

\begin{tabular}{|c|c|c|c|c|c|c|}
\hline \multirow[b]{2}{*}{ Analyte } & \multicolumn{3}{|c|}{ Quantitation Limits ${ }^{b}$} & \multicolumn{3}{|c|}{ Analytical Method ${ }^{d}$} \\
\hline & $\begin{array}{l}\text { Soil/Sediment }{ }^{\mathrm{c}} \\
(\mu \mathrm{g} / \mathrm{g} \text { or } \mathrm{mg} / \mathrm{kg})\end{array}$ & $\begin{array}{l}\text { Groundwater } \\
(\mu / / \mathrm{L})\end{array}$ & $\begin{array}{c}\text { Surface Water } \\
(\mu g / \mathrm{L})\end{array}$ & Soil/Sediment & Groundwater & Surface Water \\
\hline bis(2-Chloroethyl)ether & 330 & 10 & 10 & $\begin{array}{l}\text { EPA CLP } \\
\text { SOW (OLM01.5) }\end{array}$ & $\begin{array}{l}\text { EPA CLP } \\
\text { SOW (OLM01.5) }\end{array}$ & $\begin{array}{l}\text { EPA CLP } \\
\text { SOW (OLM01.5) }\end{array}$ \\
\hline bis(2-Chloroethoxy)methane & 330 & 10 & 10 & $\begin{array}{l}\text { EPA CLP } \\
\text { SOW (OLM01.5) }\end{array}$ & $\begin{array}{l}\text { EPA CLP } \\
\text { SOW (OLM01.5) }\end{array}$ & $\begin{array}{l}\text { EPA CLP } \\
\text { SOW (OLM01.5) }\end{array}$ \\
\hline 4-Chloro-3-methylphenol & 330 & 10 & 10 & $\begin{array}{l}\text { EPA CLP } \\
\text { SOW (OLM01.5) }\end{array}$ & $\begin{array}{l}\text { EPA CLP } \\
\text { SOW (OLM01.5) }\end{array}$ & $\begin{array}{l}\text { EPA CLP } \\
\text { SOW (OLM01.5) }\end{array}$ \\
\hline 2-Chloronaphthalene & 330 & 10 & $5^{\mathrm{e}, \mathrm{f}}$ & $\begin{array}{l}\text { EPA CLP } \\
\text { SOW (OLM01.5) }\end{array}$ & $\begin{array}{l}\text { EPA CLP } \\
\text { SOW (OLM01.5) }\end{array}$ & $\begin{array}{l}\text { EPA CLP } \\
\text { SOW (OLM01.5) }\end{array}$ \\
\hline 2-Chlorophenol & 330 & 10 & 10 & $\begin{array}{l}\text { EPA CLP } \\
\text { SOW (OLM01.5) }\end{array}$ & $\begin{array}{l}\text { EPA CLP } \\
\text { SOW (OLM01.5) }\end{array}$ & $\begin{array}{l}\text { EPA CLP } \\
\text { SOW (OLM01.5) }\end{array}$ \\
\hline 4-Chlorophenyl phenyl ether & 330 & 10 & 10 & $\begin{array}{l}\text { EPA CLP } \\
\text { SOW (OLM01.5) }\end{array}$ & $\begin{array}{l}\text { EPA CLP } \\
\text { SOW (OLM01.5) }\end{array}$ & $\begin{array}{l}\text { EPA CLP } \\
\text { SOW (OLM01.5) }\end{array}$ \\
\hline Chrysene & 330 & 10 & 10 & $\begin{array}{l}\text { EPA CLP } \\
\text { SOW (OLM01.5) }\end{array}$ & $\begin{array}{l}\text { EPA CLP } \\
\text { SOW (OLM01.5) }\end{array}$ & $\begin{array}{l}\text { EPA CLP } \\
\text { SOW (OLM01.5) }\end{array}$ \\
\hline 2,2'-oxybis-(1-Chloropropane) ${ }^{\mathrm{g}}$ & 330 & 10 & 10 & $\begin{array}{l}\text { EPA CLP } \\
\text { SOW (OLM01.5) }\end{array}$ & $\begin{array}{l}\text { EPA CLP } \\
\text { SOW (OLM01.5) }\end{array}$ & $\begin{array}{l}\text { EPA CLP } \\
\text { SOW (OLM01.5) }\end{array}$ \\
\hline Dibenz $[a, h]$ anthracene & $330 / 50^{\theta, \mathrm{f}}$ & 10 & 10 & $\begin{array}{l}\text { EPA CLP } \\
\text { SOW (OLM01.5) }\end{array}$ & $\begin{array}{l}\text { EPA CLP } \\
\text { SOW (OLM01.5) }\end{array}$ & $\begin{array}{l}\text { EPA CLP } \\
\text { SOW (OLM01.5) }\end{array}$ \\
\hline Dibenzofuran & 330 & 10 & 10 & $\begin{array}{l}\text { EPA CLP } \\
\text { SOW (OLM01.5) }\end{array}$ & $\begin{array}{l}\text { EPA CLP } \\
\text { SOW (OLM01.5) }\end{array}$ & $\begin{array}{l}\text { EPA CLP } \\
\text { SOW (OLM01.5) }\end{array}$ \\
\hline 1,2-Dichlorobenzene & 330 & 10 & 10 & $\begin{array}{l}\text { EPA CLP } \\
\text { SOW (OLM01.5) }\end{array}$ & $\begin{array}{l}\text { EPA CLP } \\
\text { SOW (OLM01.5) }\end{array}$ & $\begin{array}{l}\text { EPA CLP } \\
\text { SOW (OLM01.5) }\end{array}$ \\
\hline 1,3-Dichlorobenzene & 330 & 10 & 10 & $\begin{array}{l}\text { EPA CLP } \\
\text { SOW (OLM01.5) }\end{array}$ & $\begin{array}{l}\text { EPA CLP } \\
\text { SOW (OLM01.5) }\end{array}$ & $\begin{array}{l}\text { EPA CLP } \\
\text { SOW (OLM01.5) }\end{array}$ \\
\hline 1,4-Dichlorobenzene & 330 & 10 & 10 & $\begin{array}{l}\text { EPA CLP } \\
\text { SOW (OLM01.5) }\end{array}$ & $\begin{array}{l}\text { EPA CLP } \\
\text { SOW (OLM01.5) }\end{array}$ & $\begin{array}{l}\text { EPA CLP } \\
\text { SOW (OLM01.5) }\end{array}$ \\
\hline
\end{tabular}


TABLE C.2 (Cont.)

\begin{tabular}{|c|c|c|c|c|c|c|}
\hline \multirow[b]{3}{*}{ Analyte } & \multicolumn{3}{|c|}{ Quantitation Limits ${ }^{\mathrm{b}}$} & \multirow{2}{*}{\multicolumn{3}{|c|}{ Analytical Method ${ }^{d}$}} \\
\hline & \multirow{2}{*}{$\begin{array}{l}\text { Soil/Sediment }{ }^{\mathrm{c}} \\
(\mu \mathrm{g} / \mathrm{g} \text { or } \mathrm{mg} / \mathrm{kg})\end{array}$} & \multirow{2}{*}{$\begin{array}{c}\text { Groundwater } \\
(\mu \mathrm{g} / \mathrm{L})\end{array}$} & \multirow{2}{*}{$\begin{array}{c}\text { Surface Water } \\
(\mu g / L)\end{array}$} & & & \\
\hline & & & & Soil/Sediment & Groundwater & Surface Water \\
\hline 3,3'-Dichlorobenzidine & 330 & 10 & 10 & $\begin{array}{l}\text { EPA CLP } \\
\text { SOW (OLM01.5) }\end{array}$ & $\begin{array}{l}\text { EPA CLP } \\
\text { SOW (OLM01.5) }\end{array}$ & $\begin{array}{l}\text { EPA CLP } \\
\text { SOW (OLM01.5) }\end{array}$ \\
\hline 2,4-Dichlorophenol & 330 & 10 & 10 & $\begin{array}{l}\text { EPA CLP } \\
\text { SOW (OLM01.5) }\end{array}$ & $\begin{array}{l}\text { EPA CLP } \\
\text { SOW (OLM01.5) }\end{array}$ & $\begin{array}{l}\text { EPA CLP } \\
\text { SOW (OLM01.5) }\end{array}$ \\
\hline Diethylphthalate & 330 & 10 & 10 & $\begin{array}{l}\text { EPA CLP } \\
\text { SOW (OLM01.5) }\end{array}$ & $\begin{array}{l}\text { EPA CLP } \\
\text { SOW (OLM01.5) }\end{array}$ & $\begin{array}{l}\text { EPA CLP } \\
\text { SOW (OLM01.5) }\end{array}$ \\
\hline 2,4-Dimethylphenol & 330 & 10 & 10 & $\begin{array}{l}\text { EPA CLP } \\
\text { SOW (OLM01.5) }\end{array}$ & $\begin{array}{l}\text { EPA CLP } \\
\text { SOW (OLM01.6) }\end{array}$ & $\begin{array}{l}\text { EPA CLP } \\
\text { SOW (OLM01.5) }\end{array}$ \\
\hline Dimethylphthalate & 330 & 10 & 10 & $\begin{array}{l}\text { EPA CLP } \\
\text { SOW (OLM01.5) }\end{array}$ & $\begin{array}{l}\text { EPA CLP } \\
\text { SOW (OLM01.5) }\end{array}$ & $\begin{array}{l}\text { EPA CLP } \\
\text { SOW (OLM01.5) }\end{array}$ \\
\hline 4,6-Dinitro-2-methylphenol & 800 & 25 & 25 & $\begin{array}{l}\text { EPA CLP } \\
\text { SOW (OLM01.5) }\end{array}$ & $\begin{array}{l}\text { EPA CLP } \\
\text { SOW (OLM01.5) }\end{array}$ & $\begin{array}{l}\text { EPA CLP } \\
\text { SOW (OLM01.5) }\end{array}$ \\
\hline 2,4-Dinitrophenol & 800 & 10 & 10 & $\begin{array}{l}\text { EPA CLP } \\
\text { SOW (OLM01.5) }\end{array}$ & $\begin{array}{l}\text { EPA CLP } \\
\text { SOW (OLM01.5) }\end{array}$ & $\begin{array}{l}\text { EPA CLP } \\
\text { SOW (OLM01.5) }\end{array}$ \\
\hline 2,4-Dinitrotoluene & 330 & 10 & 10 & $\begin{array}{l}\text { EPA CLP } \\
\text { SOW (OLM01.5) }\end{array}$ & $\begin{array}{l}\text { EPA CLP } \\
\text { SOW (OLM01.5) }\end{array}$ & $\begin{array}{l}\text { EPA CLP } \\
\text { SOW (OLM01.5) }\end{array}$ \\
\hline 2,6-Dinitrotoluene & 330 & 10 & 10 & $\begin{array}{l}\text { EPA CLP } \\
\text { SOW (OLM01.5) }\end{array}$ & $\begin{array}{l}\text { EPA CLP } \\
\text { SOW (OLM01.5) }\end{array}$ & $\begin{array}{l}\text { EPA CLP } \\
\text { SOW (OLM01.5) }\end{array}$ \\
\hline Di-n-octylphthalate & 330 & 10 & 10 & $\begin{array}{l}\text { EPA CLP } \\
\text { SOW (OLM01.5) }\end{array}$ & $\begin{array}{l}\text { EPA CLP } \\
\text { SOW (OLM01.5) }\end{array}$ & $\begin{array}{l}\text { EPA CLP } \\
\text { SOW (OLM01.5) }\end{array}$ \\
\hline bis(2-Ethylhexyl)phthalate & 330 & $4^{h}$ & 10 & $\begin{array}{l}\text { EPA CLP } \\
\text { SOW (OLM01.5) }\end{array}$ & $\begin{array}{l}\text { EPA } \\
6004-88039\end{array}$ & $\begin{array}{l}\text { EPA CLP } \\
\text { SOW (OLM01.5) }\end{array}$ \\
\hline Fluoranthene & 330 & 10 & 10 & $\begin{array}{l}\text { EPA CLP } \\
\text { SOW (OLM01.5) }\end{array}$ & $\begin{array}{l}\text { EPA CLP } \\
\text { SOW (OLM01.5) }\end{array}$ & $\begin{array}{l}\text { EPA CLP } \\
\text { SOW (OLM01.5) }\end{array}$ \\
\hline Fluorene & $330 / 30^{\mathrm{e}, \mathrm{f}}$ & 10 & 10 & $\begin{array}{l}\text { EPA CLP } \\
\text { SOW (OLM01.5) }\end{array}$ & $\begin{array}{l}\text { EPA CLP } \\
\text { SOW (OLM01.5) }\end{array}$ & $\begin{array}{l}\text { EPA CLP } \\
\text { SOW (OLM01.5) }\end{array}$ \\
\hline
\end{tabular}


TABLE C.2 (Cont.)

\begin{tabular}{|c|c|c|c|c|c|c|}
\hline \multirow[b]{3}{*}{ Analyte } & \multicolumn{3}{|c|}{ Quantitation Limits ${ }^{\mathrm{b}}$} & \multirow{2}{*}{\multicolumn{3}{|c|}{ Analytical Methodd }} \\
\hline & \multirow{2}{*}{$\begin{array}{l}\text { Soil/Sediment }{ }^{c} \\
(\mu \mathrm{g} / \mathrm{g} \text { or } \mathrm{mg} / \mathrm{kg})\end{array}$} & \multirow{2}{*}{$\begin{array}{c}\text { Groundwater } \\
(\mu \mathrm{g} / \mathrm{L})\end{array}$} & \multirow{2}{*}{$\begin{array}{l}\text { Surface Water } \\
(\mu g / L)\end{array}$} & & & \\
\hline & & & & Soil/Sediment & Groundwater & Surface Water \\
\hline Hexachlorobenzene & 330 & $1^{\mathrm{e}, \mathbf{h}}$ & $5^{f}$ & $\begin{array}{l}\text { EPA CLP } \\
\text { SOW (OLM01.5) }\end{array}$ & $\begin{array}{l}\text { EPA } \\
6004-88039\end{array}$ & EPA $6004-88039$ \\
\hline Hexachlorobutadiene & 330 & 10 & $5^{f}$ & $\begin{array}{l}\text { EPA CLP } \\
\text { SOW (OLM01.5) }\end{array}$ & $\begin{array}{l}\text { EPA CLP } \\
\text { SOW (OLM01.5) }\end{array}$ & $\begin{array}{l}\text { EPA } \\
6004-88039^{i}\end{array}$ \\
\hline Hexachlorocyclopentadiene & 330 & 10 & $5^{f}$ & $\begin{array}{l}\text { EPA CLP } \\
\text { SOW (OLM01.5) }\end{array}$ & $\begin{array}{l}\text { EPA CLP } \\
\text { SOW (OLM01.5) }\end{array}$ & $\begin{array}{l}\text { EPA } \\
6004-88039^{i}\end{array}$ \\
\hline Hexachloroethane & 330 & 10 & 10 & $\begin{array}{l}\text { EPA CLP } \\
\text { SOW (OLM01.5) }\end{array}$ & $\begin{array}{l}\text { EPA CLP } \\
\text { SOW (OLM01.5) }\end{array}$ & $\begin{array}{l}\text { EPA CLP } \\
\text { SOW (OLM01.5) }\end{array}$ \\
\hline Indeno $[1,2,3-c, d]$ pyrene & 330 & 10 & 10 & $\begin{array}{l}\text { EPA CLP } \\
\text { SOW (OLM01.5) }\end{array}$ & $\begin{array}{l}\text { EPA CLP } \\
\text { SOW (OLM01.5) }\end{array}$ & $\begin{array}{l}\text { EPA CLP } \\
\text { SOW (OLM01.5) }\end{array}$ \\
\hline Isophorone & 330 & 10 & 10 & $\begin{array}{l}\text { EPA CLP } \\
\text { SOW (OLM01.5) }\end{array}$ & $\begin{array}{l}\text { EPA CLP } \\
\text { SOW (OLM01.5) }\end{array}$ & $\begin{array}{l}\text { EPA CLP } \\
\text { SOW (OLM01.5) }\end{array}$ \\
\hline 2-Methylnaphthalene & $330 / 50^{e, f}$ & 10 & 10 & $\begin{array}{l}\text { EPA CLP } \\
\text { SOW (OLM01.5) }\end{array}$ & $\begin{array}{l}\text { EPA CLP } \\
\text { SOW (OLM01.5) }\end{array}$ & $\begin{array}{l}\text { EPA CLP } \\
\text { SOW (OLM01.5) }\end{array}$ \\
\hline 2-Methylphenol & 330 & 10 & 10 & $\begin{array}{l}\text { EPA CLP } \\
\text { SOW (OLM01.5) }\end{array}$ & $\begin{array}{l}\text { EPA CLP } \\
\text { SOW (OLM01.5) }\end{array}$ & $\begin{array}{l}\text { EPA CLP } \\
\text { SOW (OLM01.5) }\end{array}$ \\
\hline 4-Methylphenol & 330 & 10 & 10 & $\begin{array}{l}\text { EPA CLP } \\
\text { SOW (OLM01.5) }\end{array}$ & $\begin{array}{l}\text { EPA CLP } \\
\text { SOW (OLM01.5) }\end{array}$ & $\begin{array}{l}\text { EPA CLP } \\
\text { SOW (OLM01.5) }\end{array}$ \\
\hline Naphthalene & 330 & 10 & 10 & $\begin{array}{l}\text { EPA CLP } \\
\text { SOW (OLM01.5) }\end{array}$ & $\begin{array}{l}\text { EPA CLP } \\
\text { SOW (OLM01.5) }\end{array}$ & $\begin{array}{l}\text { EPA CLP } \\
\text { SOW (OLM01.5) }\end{array}$ \\
\hline 2-Nitroaniline & 800 & 10 & 10 & $\begin{array}{l}\text { EPA CLP } \\
\text { SOW (OLM01.5) }\end{array}$ & $\begin{array}{l}\text { EPA CLP } \\
\text { SOW (OLM01.5) }\end{array}$ & $\begin{array}{l}\text { EPA CLP } \\
\text { SOW (OLM01.5) }\end{array}$ \\
\hline 3-Nitroaniline & 800 & 10 & 10 & $\begin{array}{l}\text { EPA CLP } \\
\text { SOW (OLM01.5) }\end{array}$ & $\begin{array}{l}\text { EPA CLP } \\
\text { SOW (OLM01.5) }\end{array}$ & $\begin{array}{l}\text { EPA CLP } \\
\text { SOW (OLM01.5) }\end{array}$ \\
\hline 4-Nitroaniline & 800 & 25 & 25 & $\begin{array}{l}\text { EPA CLP } \\
\text { SOW (OLM01.5) }\end{array}$ & $\begin{array}{l}\text { EPA CLP } \\
\text { SOW (OLM01.5) }\end{array}$ & $\begin{array}{l}\text { EPA CLP } \\
\text { SOW (OLM01.5) }\end{array}$ \\
\hline
\end{tabular}


TABLE C.2 (Cont.)

\begin{tabular}{|c|c|c|c|c|c|c|}
\hline \multirow[b]{3}{*}{ Analyte } & \multicolumn{3}{|c|}{ Quantitation Limits } & \multirow{2}{*}{\multicolumn{3}{|c|}{ Analytical Method ${ }^{\mathrm{d}}$}} \\
\hline & \multirow{2}{*}{$\begin{array}{l}\text { Soil/Sediment } \\
\text { ( } \mathrm{\mu g} / \mathrm{g} \text { or } \mathrm{mg} / \mathrm{kg})\end{array}$} & \multirow[b]{2}{*}{$\begin{array}{c}\text { Groundwater } \\
(\mu \mathrm{g} / \mathrm{L})\end{array}$} & \multirow[b]{2}{*}{$\begin{array}{c}\text { Surface Water } \\
(\mu \mathrm{g} / \mathrm{L})\end{array}$} & & & \\
\hline & & & & Soil/Sediment & Groundwater & Surface Water \\
\hline Nitrobenzene & 330 & 10 & 10 & $\begin{array}{l}\text { EPA CLP } \\
\text { SOW (OLM01.5) }\end{array}$ & $\begin{array}{l}\text { EPA CLP } \\
\text { SOW (OLM01.5) }\end{array}$ & $\begin{array}{l}\text { EPA CLP } \\
\text { SOW (OLM01.5) }\end{array}$ \\
\hline 2-Nitrophenol & 330 & 10 & 10 & $\begin{array}{l}\text { EPA CLP } \\
\text { SOW (OLM01.5) }\end{array}$ & $\begin{array}{l}\text { EPA CLP } \\
\text { SOW (OLM01.5) }\end{array}$ & $\begin{array}{l}\text { EPA CLP } \\
\text { SOW (OLM01.5) }\end{array}$ \\
\hline 4-Nitrophenol & 800 & 10 & 10 & $\begin{array}{l}\text { EPA CLP } \\
\text { SOW (OLM01.5) }\end{array}$ & $\begin{array}{l}\text { EPA CLP } \\
\text { SOW (OLM01.5) }\end{array}$ & $\begin{array}{l}\text { EPA CLP } \\
\text { SOW (OLM01.5) }\end{array}$ \\
\hline$N$-Nitroso-di- $n$-propylamine & 330 & 10 & 10 & $\begin{array}{l}\text { EPA CLP } \\
\text { SOW (OLM01.5) }\end{array}$ & $\begin{array}{l}\text { EPA CLP } \\
\text { SOW (OLM01.5) }\end{array}$ & $\begin{array}{l}\text { EPA CLP } \\
\text { SOW (OLM01.5) }\end{array}$ \\
\hline$N$-Nitrosodiphenylamine & 330 & 10 & 10 & $\begin{array}{l}\text { EPA CLP } \\
\text { SOW (OLM01.5) }\end{array}$ & $\begin{array}{l}\text { EPA CLP } \\
\text { SOW (OLM01.5) }\end{array}$ & $\begin{array}{l}\text { EPA CLP } \\
\text { SOW (OLM01.5) }\end{array}$ \\
\hline Pentachlorophenol & 800 & $1^{e, h}$ & $5^{f}$ & $\begin{array}{l}\text { EPA CLP } \\
\text { SOW (OLM01.5) }\end{array}$ & $\begin{array}{l}\text { EPA } \\
6004-88039^{i}\end{array}$ & $\begin{array}{l}\text { EPA } \\
6004-88039^{i}\end{array}$ \\
\hline Phenanthrene & $330 / 200^{\mathrm{e}, \mathrm{f}}$ & 10 & $5^{f}$ & $\begin{array}{l}\text { EPA CLP } \\
\text { SOW (OLM01.5) }\end{array}$ & $\begin{array}{l}\text { EPA CLP } \\
\text { SOW (OLM01.5) }\end{array}$ & $\begin{array}{l}\text { EPA } \\
6004-88.039^{i}\end{array}$ \\
\hline Phenol & 330 & 10 & 10 & $\begin{array}{l}\text { EPA CLP } \\
\text { SOW (OLM01.5) }\end{array}$ & $\begin{array}{l}\text { EPA CLP } \\
\text { SOW (OLM01.5) }\end{array}$ & $\begin{array}{l}\text { EPA CLP } \\
\text { SOW (OLM01.5) }\end{array}$ \\
\hline Pyrene & 330 & 10 & 10 & $\begin{array}{l}\text { EPA CLP } \\
\text { SOW (OLM01.5) }\end{array}$ & $\begin{array}{l}\text { EPA CLP } \\
\text { SOW (OLM01.5) }\end{array}$ & $\begin{array}{l}\text { EPA CLP } \\
\text { SOW (OLM01.5) }\end{array}$ \\
\hline 1,2,4-Trichlorobenzene & 330 & $5^{\text {h }}$ & 10 & $\begin{array}{l}\text { EPA CLP } \\
\text { SOW (OLM01.5) }\end{array}$ & $\begin{array}{l}\text { EPA } \\
6004-88039^{i}\end{array}$ & $\begin{array}{l}\text { EPA CLP } \\
\text { SOW (OLM01.5) }\end{array}$ \\
\hline 2,4,5-Trichlorophenol & 800 & 10 & 10 & $\begin{array}{l}\text { EPA CLP } \\
\text { SOW (OLM01.5) }\end{array}$ & $\begin{array}{l}\text { EPA CLP } \\
\text { SOW (OLM01.5) }\end{array}$ & $\begin{array}{l}\text { EPA CLP } \\
\text { SOW (OLM01.5) }\end{array}$ \\
\hline 2,4,6-Trichlorophenol & 330 & 10 & 10 & $\begin{array}{l}\text { EPA CLP } \\
\text { SOW (OLM01.5) }\end{array}$ & $\begin{array}{l}\text { EPA CLP } \\
\text { SOW (OLM01.5) }\end{array}$ & $\begin{array}{l}\text { EPA CLP } \\
\text { SOW (OLM01.5) }\end{array}$ \\
\hline
\end{tabular}

See footnotes on next page. 


\section{TABLE C.2 (Cont.)}

a Recommended quantitation limits are equal to the EPA's contract-required quantitation limits (CRQLs), unless otherwise noted. The CRQL is the lowest level that can be reliably achieved within specified limits of precision and accuracy during routine laboratory operating conditions. For the CLP methodologies, the CRQL is determined by the lowest initial calibration standard that is run before the analytical sequence.

b Quantitation limits listed for soil/sediment are based on wet weight. The quantitation limits calculated by the laboratory for soil/sediment are calculated on a dryweight basis and, therefore, will be higher.

c If two values are listed, the first is the recommended quantitation limit of soil and the second is the recommended quantitation limit for sediment.

d Sources of analytical methods, except as noted: EPA CLP, Statement of Work (SOW) (OLM01.5) = EPA (1991) (note that for semivolatile organic analysis of sediment samples, standing liquid should be discarded prior to extraction); EPA 600 4-88 039 = EPA (1988) (Method 525, Determination of Organic Compounds in Drinking Water by Liquid-Solid Extraction and Capillary Column Gas Chromatography/Mass Spectrometry; note that several hardware configurations exist for this method and that the referenced values are for the ion trap mass-spectrometer configuration).

- Although this limit cannot be achieved using the referenced methodology, the compound can be detected and confirmed at less than the quantitation limit. This value would be confirmed but considered estimated and available for use in risk assessment.

f Recommended alternate quantitation limit based on potential aquatic toxicity.

$g$ Previously known by the name bis(2-chloroisopropyl)ether.

h Recommended alternate quantitation limit based on potential human toxicity.

i EPA (1988) (Method 524.2, Measurement of Purgeable Organic Compounds in Water by Capillary Column Gas Chromatography/Mass Spectrometry; note that several hardware configurations exist for this method and that the referenced values are for the following configurations: wide-bore capillary column, jet separator, and quadrapole mass spectrometer). 
TABLE C.3 Target Compound List, Analytical Methods, and Quantitation Limits: Pesticides/PCBs/Aroclors $^{\mathrm{a}}$

\begin{tabular}{|c|c|c|c|c|c|c|}
\hline \multirow[b]{3}{*}{ Analyte } & \multicolumn{3}{|c|}{ Quantitation Limits ${ }^{b, c}$} & & & \\
\hline & \multirow{2}{*}{$\begin{array}{l}\text { Soil/Sediment }{ }^{d} \\
\text { ( } \mu g / g \text { or } \mathrm{mg} / \mathrm{kg} \text { ) }\end{array}$} & \multirow{2}{*}{$\begin{array}{c}\text { Groundwater } \\
(\mu g / L)\end{array}$} & \multirow{2}{*}{$\begin{array}{l}\text { Surface Water } \\
(\mu \mathrm{g} / \mathrm{L})\end{array}$} & \multicolumn{3}{|c|}{ Analytical Method ${ }^{\Theta}$} \\
\hline & & & & Soil/Sediment & Groundwater & Surface Water \\
\hline Aldrin & 1.7 & 0.05 & 0.05 & $\begin{array}{l}\text { CLP SOW } \\
\text { (OLM01.5) }\end{array}$ & $\begin{array}{l}\text { CLP SOW } \\
\text { (OLM01.5) }\end{array}$ & $\begin{array}{l}\text { CLP SOW } \\
\text { (OLM01.5) }\end{array}$ \\
\hline alpha-BHC & 1.7 & 0.05 & 0.05 & $\begin{array}{l}\text { CLP SOW } \\
\text { (OLM01.5) }\end{array}$ & $\begin{array}{l}\text { CLP SOW } \\
\text { (OLM01.5) }\end{array}$ & $\begin{array}{l}\text { CLP SOW } \\
\text { (OLM01.5) }\end{array}$ \\
\hline beta-BHC & 1.7 & 0.05 & 0.05 & $\begin{array}{l}\text { CLP SOW } \\
\text { (OLM01.5) }\end{array}$ & $\begin{array}{l}\text { CLP SOW } \\
\text { (OLM01.5) }\end{array}$ & $\begin{array}{l}\text { CLP SOW } \\
\text { (OLM01.5) }\end{array}$ \\
\hline delta-BHC & 1.7 & 0.05 & 0.05 & $\begin{array}{l}\text { CLP SOW } \\
\text { (OLM01.5) }\end{array}$ & $\begin{array}{l}\text { CLP SOW } \\
\text { (OLM01.5) }\end{array}$ & $\begin{array}{l}\text { CLP SOW } \\
\text { (OLM01.5) }\end{array}$ \\
\hline gamma-BHC (lindane) & 1.7 & 0.05 & 0.05 & $\begin{array}{l}\text { CLP SOW } \\
\text { (OLM01.5) }\end{array}$ & $\begin{array}{l}\text { CLP SOW } \\
\text { (OLM01.5) }\end{array}$ & $\begin{array}{l}\text { CLP SOW } \\
\text { (OLM01.5) }\end{array}$ \\
\hline alpha-Chlordane & $1.7 / 0.5^{f}(1.7)$ & 0.05 & $\begin{array}{c}0.001^{f} \\
(0.0015)^{g}\end{array}$ & $\begin{array}{l}\text { CLP SOW } \\
\text { (OLM01.5) }\end{array}$ & $\begin{array}{l}\text { CLP SOW } \\
\text { (OLM01.5) }\end{array}$ & $\begin{array}{l}\text { EPA-600/ } \\
4-82-057\end{array}$ \\
\hline gamma-Chlordane & $1.7 / 0.5^{f}(1.7)$ & 0.05 & $\begin{array}{c}0.001^{f} \\
(0.0015)^{g}\end{array}$ & $\begin{array}{l}\text { CLP SOW } \\
\text { (OLM01.5) }\end{array}$ & $\begin{array}{l}\text { CLP SOW } \\
\text { (OLM01.5) }\end{array}$ & $\begin{array}{l}\text { EPA-600/ } \\
4-82-057\end{array}$ \\
\hline 4,4-DDD & $3.3 / 2^{f}(3.3)$ & 0.1 & $\begin{array}{c}0.001^{f} \\
(0.0025)^{g}\end{array}$ & $\begin{array}{l}\text { CLP SOW } \\
\text { (OLM01.5) }\end{array}$ & $\begin{array}{l}\text { CLP SOW } \\
\text { (OLM01.5) }\end{array}$ & $\begin{array}{l}\text { EPA-600/ } \\
4-82-057\end{array}$ \\
\hline $4,4-\mathrm{DDE}$ & $3.3 / 2^{f}(3.3)$ & 0.1 & $\begin{array}{l}0.001^{f} \\
(0.01)^{g}\end{array}$ & $\begin{array}{l}\text { CLP SOW } \\
\text { (OLM01.5) }\end{array}$ & $\begin{array}{l}\text { CLP SOW } \\
\text { (OLM01.5) }\end{array}$ & $\begin{array}{l}\text { EPA-600/ } \\
4-82-057\end{array}$ \\
\hline 4,4-DDT & $3.3 / 1^{f}(3.3)$ & 0.1 & $\begin{array}{c}0.001^{f} \\
(0.06)^{g}\end{array}$ & $\begin{array}{l}\text { CLP SOW } \\
\text { (OLM01.5) }\end{array}$ & $\begin{array}{l}\text { CLP SOW } \\
\text { (OLM01.5) }\end{array}$ & $\begin{array}{l}\text { EPA-600/ } \\
4-82-057\end{array}$ \\
\hline Dieldrin & $3.3 / 0.02^{f}(3.3)$ & 0.1 & $\begin{array}{c}0.001^{f} \\
(0.02)^{g}\end{array}$ & $\begin{array}{l}\text { CLP SOW } \\
\text { (OLM01.5) }\end{array}$ & $\begin{array}{l}\text { CLP SOW } \\
\text { (OLM01.5) }\end{array}$ & $\begin{array}{l}\text { EPA-600/ } \\
4-82-057\end{array}$ \\
\hline Endosulfan I & 1.7 & 0.05 & $\begin{array}{c}0.001^{f} \\
(0.015)^{g}\end{array}$ & $\begin{array}{l}\text { CLP SOW } \\
\text { (OLM01.5) }\end{array}$ & $\begin{array}{l}\text { CLP SOW } \\
\text { (OLM01.5) }\end{array}$ & $\begin{array}{l}\text { EPA-600/ } \\
4-82-057\end{array}$ \\
\hline Endosulfan II & 3.3 & 0.1 & $\begin{array}{c}0.001^{\mathrm{f}} \\
(0.024)^{g}\end{array}$ & $\begin{array}{l}\text { CLP SOW } \\
\text { (OLM01.5) }\end{array}$ & $\begin{array}{l}\text { CLP SOW } \\
\text { (OLM01.5) }\end{array}$ & $\begin{array}{l}\text { EPA-600/ } \\
4-82-057\end{array}$ \\
\hline
\end{tabular}


TABLE C.3 (Cont.)

\begin{tabular}{|c|c|c|c|c|c|c|}
\hline \multirow[b]{3}{*}{ Analyte } & \multicolumn{3}{|c|}{ Quantitation Limits $^{b, c}$} & \multirow{2}{*}{\multicolumn{3}{|c|}{ Analytical Method ${ }^{\circ}$}} \\
\hline & \multirow{2}{*}{$\begin{array}{l}\text { Soil/Sediment }{ }^{d} \\
(\mu g / g \text { or } \mathrm{mg} / \mathrm{kg})\end{array}$} & \multirow{2}{*}{$\begin{array}{c}\text { Groundwater } \\
(\mu \mathrm{g} / \mathrm{L})\end{array}$} & \multirow{2}{*}{$\begin{array}{c}\text { Surface Water } \\
(\mu \mathrm{g} / \mathrm{L})\end{array}$} & & & \\
\hline & & & & Soil/Sediment & Groundwater & Surface Water \\
\hline Endosulfan sulfate & 3.3 & 0.1 & $\begin{array}{c}0.001^{f} \\
(0.015)^{8}\end{array}$ & $\begin{array}{l}\text { CLP SOW } \\
\text { (OLM01.5) }\end{array}$ & $\begin{array}{l}\text { CLP SOW } \\
\text { (OLM01.5) }\end{array}$ & $\begin{array}{l}\text { EPA-600/ } \\
4-82-057\end{array}$ \\
\hline Endrin & $3.3 / 0.02^{f}(3.3)$ & 0.1 & $\begin{array}{c}0.001^{f} \\
(0.015)^{8}\end{array}$ & $\begin{array}{l}\text { CLP SOW } \\
\text { (OLM01.5) }\end{array}$ & $\begin{array}{l}\text { CLP SOW } \\
\text { (OLM01.5) }\end{array}$ & $\begin{array}{l}\text { EPA-600/ } \\
4-82-057\end{array}$ \\
\hline Endrin aldehyde & 3.3 & 0.1 & $\begin{array}{c}0.001^{f} \\
(0.025)^{g}\end{array}$ & $\begin{array}{l}\text { CLP SOW } \\
\text { (OLM01.5) }\end{array}$ & $\begin{array}{l}\text { CLP SOW } \\
\text { (OLM01.5) }\end{array}$ & $\begin{array}{l}\text { EPA-600/ } \\
4-82-057\end{array}$ \\
\hline Endrin ketone & 3.3 & 0.1 & $\begin{array}{l}0.001^{\mathrm{f}} \\
(0.01)^{\mathrm{g}}\end{array}$ & $\begin{array}{l}\text { CLP SOW } \\
\text { (OLM01.5) }\end{array}$ & $\begin{array}{l}\text { CLP SOW } \\
\text { (OLM01.5) }\end{array}$ & $\begin{array}{l}\text { CLP SOW } \\
\text { (OLM01.5) }\end{array}$ \\
\hline Heptachlor & 1.7 & 0.05 & $\begin{array}{l}0.001^{\mathrm{f}} \\
(0.01)^{\mathrm{g}}\end{array}$ & $\begin{array}{l}\text { CLP SOW } \\
\text { (OLM01.5) }\end{array}$ & $\begin{array}{l}\text { CLP SOW } \\
\text { (OLM01.5) }\end{array}$ & $\begin{array}{l}\text { EPA-600/ } \\
4-82-057\end{array}$ \\
\hline Heptachlor epoxide & 1.7 & 0.05 & $\begin{array}{c}0.001^{f} \\
(0.015)^{g}\end{array}$ & $\begin{array}{l}\text { CLP SOW } \\
\text { (OLM01.5) }\end{array}$ & $\begin{array}{l}\text { CLP SOW } \\
\text { (OLM01.5) }\end{array}$ & $\begin{array}{l}\text { EPA-600/ } \\
4-82-057\end{array}$ \\
\hline Methoxychlor & 17 & 0.5 & $\begin{array}{c}0.01^{\mathrm{f}} \\
(0.05)^{\mathrm{g}}\end{array}$ & $\begin{array}{l}\text { CLP SOW } \\
\text { (OLM01.5) }\end{array}$ & $\begin{array}{l}\text { CLP SOW } \\
\text { (OLM01.5) }\end{array}$ & $\begin{array}{l}\text { EPA-600/ } \\
4-82-057\end{array}$ \\
\hline Aroclor-1016 & 33 & 1.0 & $\begin{array}{c}0.01^{f} \\
(0.08)^{h}\end{array}$ & $\begin{array}{l}\text { CLP SOW } \\
\text { (OLM01.5) }\end{array}$ & $\begin{array}{l}\text { CLP SOW } \\
\text { (OLM01.5) }\end{array}$ & $\begin{array}{l}\text { EPA-600/ } \\
4-82-057^{i}\end{array}$ \\
\hline Aroclor-1221 & 67 & 2.0 & $\begin{array}{c}0.01^{f} \\
(0.08)^{h}\end{array}$ & $\begin{array}{l}\text { CLP SOW } \\
\text { (OLM01.5) }\end{array}$ & $\begin{array}{l}\text { CLP SOW } \\
\text { (OLM01.5) }\end{array}$ & $\begin{array}{l}\text { EPA-600/ } \\
4-82-057^{\mathrm{i}}\end{array}$ \\
\hline Aroclor-1232 & 33 & 1.0 & $\begin{array}{l}0.01^{\mathrm{f}} \\
(2.0)^{\mathrm{h}}\end{array}$ & $\begin{array}{l}\text { CLP SOW } \\
\text { (OLM01.5) }\end{array}$ & $\begin{array}{l}\text { CLP SOW } \\
\text { (OLM01.5) }\end{array}$ & $\begin{array}{l}\text { CLP SOW } \\
\text { (OLM01.5) }\end{array}$ \\
\hline Aroclor -1242 & 33 & 1.0 & $\begin{array}{c}0.01^{\mathrm{f}} \\
(0.48)^{\mathrm{h}}\end{array}$ & $\begin{array}{l}\text { CLP SOW } \\
\text { (OLM01.5) }\end{array}$ & $\begin{array}{l}\text { CLP SOW } \\
\text { (OLM01.5) }\end{array}$ & $\begin{array}{l}\text { EPA-600/ } \\
4-82-057^{i}\end{array}$ \\
\hline Aroclor -1248 & 33 & 1.0 & $\begin{array}{c}0.01^{f} \\
(0.31)^{h}\end{array}$ & $\begin{array}{l}\text { CLP SOW } \\
\text { (OLM01.5) }\end{array}$ & $\begin{array}{l}\text { CLP SOW } \\
\text { (OLM01.5) }\end{array}$ & $\begin{array}{l}\text { EPA-600/ } \\
4-82-057^{i}\end{array}$ \\
\hline Aroclor -1254 & 33 & 1.0 & $\begin{array}{c}0.01^{\mathrm{f}} \\
(0.10)^{\mathrm{h}}\end{array}$ & $\begin{array}{l}\text { CLP SOW } \\
\text { (OLM01.5) }\end{array}$ & $\begin{array}{l}\text { CLP SOW } \\
\text { (OLM01.5) }\end{array}$ & $\begin{array}{l}\text { EPA-600/ } \\
4-82-057^{i}\end{array}$ \\
\hline
\end{tabular}


TABLE C.3 (Cont.)

\begin{tabular}{|c|c|c|c|c|c|c|}
\hline \multirow[b]{3}{*}{ Analyte } & \multicolumn{3}{|c|}{ Quantitation Limits ${ }^{b, c}$} & \multirow{2}{*}{\multicolumn{3}{|c|}{ Analytical Method $^{e}$}} \\
\hline & \multirow{2}{*}{$\begin{array}{l}\text { Soil/Sediment }{ }^{d} \\
(\mu g / g \text { or } \mathrm{mg} / \mathrm{kg})\end{array}$} & \multirow{2}{*}{$\begin{array}{c}\text { Groundwater } \\
(\mu \mathrm{g} / \mathrm{L})\end{array}$} & \multirow{2}{*}{$\begin{array}{c}\text { Surface Water } \\
(\mu g / L)\end{array}$} & & & \\
\hline & & & & Soil/Sediment & Groundwater & Surface Water \\
\hline Aroclor-1260 & 33 & 1.0 & $\begin{array}{c}0.01^{\mathrm{f}} \\
(0.19)^{\mathrm{h}}\end{array}$ & $\begin{array}{l}\text { CLP SOW } \\
\text { (OLM01.5) }\end{array}$ & $\begin{array}{l}\text { CLP SOW } \\
\text { (OLM01.5) }\end{array}$ & $\begin{array}{l}\text { EPA-600/ } \\
4-82-057^{i}\end{array}$ \\
\hline Toxaphene & 170 & $1^{h}$ & $\begin{array}{c}0.0001^{f} \\
(1.0)^{h}\end{array}$ & $\begin{array}{l}\text { CLP SOW } \\
\text { (OLM01.5) }\end{array}$ & $\begin{array}{l}\text { EPA-600/ } \\
4-82-057^{\mathfrak{i}}\end{array}$ & $\begin{array}{l}\text { EPA-600/ } \\
4-82-057^{i}\end{array}$ \\
\hline
\end{tabular}

a Recommended quantitation limits are equal to the EPA's contract-required quantitation limits (CRQLs), unless otherwise noted. The $\mathrm{CRQL}$ is the lowest level that can be reliably achieved within specified limits of precision and accuracy during routine laboratory operating conditions. For the CLP methodologies, the CRQL is determined by the lowest initial calibration standard that is run before the analytical sequence.

b Quantitation limits listed for soil/sediment are based on wet weight. The quantitation limits calculated by the laboratory for soil/sediment are calculated on a dry-weight basis and, therefore, will be higher.

c When a recommended risk-based value is not achievable using standard analytical methods, an alternate value is presented in parentheses. The value within the parentheses is the quantitation limit or detection limit that is attainable with the referenced methodology.

d If two values are listed, the first is the recommended quantitation limit for soil and the second is the recommended quantitation limit for sediment.

- Sources of analytical methods, except as noted: CLP Statement of Work (SOW) (OLM01.5) = EPA (1991) (note that for pesticide/PCB organic analysis of sediment samples, standing liquid should be discarded prior to extraction); EPA-600/4-82-057 = EPA (1988) (Method 508, Determination of Chlorinated Pesticides in Water by Gas Chromatography with an Electron Capture Detector).

i Recommended alternate quantitation limit based on potential aquatic toxicity.

g The referenced value is an estimated detection limit (EDL), defined either as the method detection limit (MDL) or as a level of compound in a sample yielding a peak in the final extract with a signal-to-noise ratio of approximately 5 , whichever is higher. The MDL is defined as the minimum concentration of a substance that can be measured and reported with a $99 \%$ confidence that the analyte concentration is greater than zero (40 CFR Part 136, Appendix B). Note that if a quantitated value is greater than the EDL or MDL values but less than the CRQL, the reported concentration would be considered estimated but available for use in risk assessment.

In The referenced value is an MDL. Note that if a quantitated value is greater than the EDL or MDL values but less than the CRQL, the reported concentration would be considered estimated but available for use in risk assessment.

i EPA (1988) (Method 505, Analysis of Organohalide Pesticides and Commercial Polychlorinated Biphenyl Products in Water by Microextraction and Gas Chromatography; note that several hardware configurations exist for this method and that the referenced values are for the following configurations: wide bore capillary column, jet separator, and quadrapole mass spectrometer). 
TABLE C.4 Target Analyte List, Analytical Methods, and Detection Limits: Inorganic Chemicals ${ }^{\mathrm{a}}$

\begin{tabular}{|c|c|c|c|c|c|c|}
\hline \multirow[b]{3}{*}{ Analyte } & \multicolumn{3}{|c|}{ Detection Limits $^{\mathrm{b}}$} & \multirow{2}{*}{\multicolumn{3}{|c|}{ Analytical Method ${ }^{c}$}} \\
\hline & \multirow{2}{*}{$\begin{array}{c}\text { Soil/Sediment } \\
(\mathrm{mg} / \mathrm{kg})\end{array}$} & \multirow{2}{*}{$\begin{array}{c}\text { Groundwater } \\
(\mu \mathrm{g} / \mathrm{L})\end{array}$} & \multirow{2}{*}{$\begin{array}{c}\text { Surface Water } \\
(\mu \mathrm{g} / \mathrm{L})\end{array}$} & & & \\
\hline & & & & Soil/Sediment & Groundwater & Surface Water \\
\hline Aluminum & 40 & 200 & $50^{d}$ & $\begin{array}{l}\text { Method } 200.7 \\
\text { EPA CLP-M }\end{array}$ & $\begin{array}{l}\text { Method } 200.7 \\
\text { EPA CLP-M }\end{array}$ & $\begin{array}{l}\text { Method } 202.2 \\
\text { EPA CLP-M }\end{array}$ \\
\hline Antimony & $12(1)$ & $5^{\mathrm{e}}$ & 60 & $\begin{array}{l}\text { Method } 200.7 \\
\text { EPA CLP-M }\end{array}$ & $\begin{array}{l}\text { Method 204.2 } \\
\text { EPA CLP-M }\end{array}$ & $\begin{array}{l}\text { Method 200.7 } \\
\text { EPA CLP-M }\end{array}$ \\
\hline Arsenic & 2 & 10 & 10 & $\begin{array}{l}\text { Method } 206.2 \\
\text { EPA CLP-M }\end{array}$ & $\begin{array}{l}\text { Method } 206.2 \\
\text { EPA CLP-M }\end{array}$ & $\begin{array}{l}\text { Method } 206.2 \\
\text { EPA CLP-M }\end{array}$ \\
\hline Barium & 40 & 200 & 200 & $\begin{array}{l}\text { Method } 200.7 \\
\text { EPA CLP-M }\end{array}$ & $\begin{array}{l}\text { Method } 200.7 \\
\text { EPA CLP-M }\end{array}$ & $\begin{array}{l}\text { Method } 200.7 \\
\text { EPA CLP-M }\end{array}$ \\
\hline Beryllium & 1 & $1^{e}$ & 5 & $\begin{array}{l}\text { Method } 210.2 \\
\text { EPA CLP-M }\end{array}$ & $\begin{array}{l}\text { Method } 210.2 \\
\text { EPA CLP-M }\end{array}$ & $\begin{array}{l}\text { Method } 200.7 \\
\text { EPA CLP-M }\end{array}$ \\
\hline Cadmium & 1 & 5 & $0.5^{\mathrm{d}}$ & $\begin{array}{l}\text { Method } 200.7 \\
\text { EPA CLP-M }\end{array}$ & $\begin{array}{l}\text { Method 200.7 } \\
\text { EPA CLP-M }\end{array}$ & $\begin{array}{l}\text { Method } 213.2 \\
\text { EPA CLP-M }\end{array}$ \\
\hline Calcium & 1,000 & 5,000 & 5,000 & $\begin{array}{l}\text { Method } 200.7 \\
\text { EPA CLP-M }\end{array}$ & $\begin{array}{l}\text { Method } 200.7 \\
\text { EPA CLP-M }\end{array}$ & $\begin{array}{l}\text { Method 200.7 } \\
\text { EPA CLP-M }\end{array}$ \\
\hline Chromium & 2 & 10 & 10 & $\begin{array}{l}\text { Method 200.7 } \\
\text { EPA CLP-M }\end{array}$ & $\begin{array}{l}\text { Method } 200.7 \\
\text { EPA CLP-M }\end{array}$ & $\begin{array}{l}\text { Method } 200.7 \\
\text { EPA CLP-M }\end{array}$ \\
\hline Cobalt & 10 & 50 & 50 & $\begin{array}{l}\text { Method } 200.7 \\
\text { EPA CLP-M }\end{array}$ & $\begin{array}{l}\text { Method } 200.7 \\
\text { EPA CLP-M }\end{array}$ & $\begin{array}{l}\text { Method } 200.7 \\
\text { EPA CLP-M }\end{array}$ \\
\hline Copper & 5 & 25 & $1^{d}$ & $\begin{array}{l}\text { Method } 200.7 \\
\text { EPA CLP-M }\end{array}$ & $\begin{array}{l}\text { Method } 200.7 \\
\text { EPA CLP-M }\end{array}$ & $\begin{array}{l}\text { Method } 220.2 \\
\text { EPA CLP-M }\end{array}$ \\
\hline Cyanide (total) & $0.7^{\mathrm{f}}$ & 10 & $1^{d}$ & $\begin{array}{l}\text { EPA CLP } \\
\text { Spectrophotometric- } \\
\text { Automated }\end{array}$ & $\begin{array}{l}\text { EPA CLP } \\
\text { Spectrophotometric- } \\
\text { Automated }\end{array}$ & $\begin{array}{l}\text { EPA CLP } \\
\text { Spectrophotometric- } \\
\text { Automated }\end{array}$ \\
\hline
\end{tabular}


TABLE C.4 (Cont.)

\begin{tabular}{|c|c|c|c|c|c|c|}
\hline \multirow[b]{3}{*}{ Analyte } & \multicolumn{3}{|c|}{ Detection Limits ${ }^{b}$} & \multirow{2}{*}{\multicolumn{3}{|c|}{ Analytical Method ${ }^{\mathrm{C}}$}} \\
\hline & \multirow{2}{*}{$\begin{array}{l}\text { Soil/Sediment } \\
(\mathrm{mg} / \mathrm{kg})\end{array}$} & \multirow{2}{*}{$\begin{array}{c}\text { Groundwater } \\
(\mu \mathrm{g} / \mathrm{L})\end{array}$} & \multirow{2}{*}{$\begin{array}{c}\text { Surface Water } \\
(\mu \mathrm{g} / \mathrm{L})\end{array}$} & & & \\
\hline & & & & Soil/Sediment & Groundwater & Surface Water \\
\hline Iron & 20 & 100 & 100 & $\begin{array}{l}\text { Method } 200.7 \\
\text { EPA CLP-M }\end{array}$ & $\begin{array}{l}\text { Method } 200.7 \\
\text { EPA CLP-M }\end{array}$ & $\begin{array}{l}\text { Method } 200.7 \\
\text { EPA CLP-M }\end{array}$ \\
\hline Lead & 0.6 & 3 & $1^{d}$ & $\begin{array}{l}\text { Method } 239.2 \\
\text { EPA CLP-M }\end{array}$ & $\begin{array}{l}\text { Method } 239.2 \\
\text { EPA CLP-M }\end{array}$ & $\begin{array}{l}\text { Method } 239.2 \\
\text { EPA CLP-M }\end{array}$ \\
\hline Magnesium & 1,000 & 5,000 & 5,000 & $\begin{array}{l}\text { Method } 200.7 \\
\text { EPA CLP-M }\end{array}$ & $\begin{array}{l}\text { Method } 200.7 \\
\text { EPA CLP-M }\end{array}$ & $\begin{array}{l}\text { Method } 200.7 \\
\text { EPA CLP-M }\end{array}$ \\
\hline Manganese & 3 & $15^{\mathrm{d}}$ & 15 & $\begin{array}{l}\text { Method } 200.7 \\
\text { EPA CLP-M }\end{array}$ & $\begin{array}{l}\text { Method } 200.7 \\
\text { EPA CLP-M }\end{array}$ & $\begin{array}{l}\text { Method } 200.7 \\
\text { EPA CLP-M }\end{array}$ \\
\hline Mercury. & $0.1(0.2)^{\mathrm{g}}$ & 0.2 & $0.01^{\mathrm{d}}$ & $\begin{array}{l}\text { Method } 245.2 \\
\text { EPA CLP-M }\end{array}$ & $\begin{array}{l}\text { Method } 245.2 \\
\text { EPA CLP-M }\end{array}$ & $\begin{array}{l}\text { Method } 245.2 \\
\text { EPA CLP-M }\end{array}$ \\
\hline Nickel & 8 & 40 & $5^{\mathrm{d}}$ & $\begin{array}{l}\text { Method } 200.7 \\
\text { EPA CLP-M }\end{array}$ & $\begin{array}{l}\text { Method } 200.7 \\
\text { EPA CLP-M }\end{array}$ & $\begin{array}{l}\text { Method } 249.2 \\
\text { EPA CLP-M }\end{array}$ \\
\hline Potassium & 1,000 & 5,000 & 5,000 & $\begin{array}{l}\text { Method } 200.7 \\
\text { EPA CLP-M }\end{array}$ & $\begin{array}{l}\text { Method } 200.7 \\
\text { EPA CLP-M }\end{array}$ & $\begin{array}{l}\text { Method } 200.7 \\
\text { EPA CLP-M }\end{array}$ \\
\hline Selenium & 1 & 5 & 5 & $\begin{array}{l}\text { Method } 270.2 \\
\text { EPA CLP-M }\end{array}$ & $\begin{array}{l}\text { Method } 270.2 \\
\text { EPA CLP-M }\end{array}$ & $\begin{array}{l}\text { Method } 270.2 \\
\text { EPA CLP-M }\end{array}$ \\
\hline Silver & 2 & 10 & $0.1^{\mathrm{d}}$ & $\begin{array}{l}\text { Method } 200.7 \\
\text { EPA CLP-M }\end{array}$ & $\begin{array}{l}\text { Method } 200.7 \\
\text { EPA CLP-M }\end{array}$ & $\begin{array}{l}\text { Method } 272.2 \\
\text { EPA CLP-M }\end{array}$ \\
\hline Sodium & 1,000 & 5,000 & 5,000 & $\begin{array}{l}\text { Method } 200.7 \\
\text { EPA CLP-M }\end{array}$ & $\begin{array}{l}\text { Method } 200.7 \\
\text { EPA CLP-M }\end{array}$ & $\begin{array}{l}\text { Method 200.7 } \\
\text { EPA CLP-M }\end{array}$ \\
\hline Thallium & 2 & $1^{e}$ & 10 & $\begin{array}{l}\text { Method } 279.2 \\
\text { EPA CLP-M }\end{array}$ & $\begin{array}{l}\text { Method } 279.2 \\
\text { EPA CLP-M }\end{array}$ & $\begin{array}{l}\text { Method } 279.2 \\
\text { EPA CLP-M }\end{array}$ \\
\hline
\end{tabular}


TABLE C.4 (Cont.)

\begin{tabular}{|c|c|c|c|c|c|c|}
\hline \multirow[b]{3}{*}{ Analyte } & \multicolumn{3}{|c|}{ Detection Limits ${ }^{\mathrm{b}}$} & & & \\
\hline & \multirow{2}{*}{$\begin{array}{l}\text { Soil/Sediment } \\
(\mathrm{mg} / \mathrm{kg})\end{array}$} & \multirow{2}{*}{$\begin{array}{c}\text { Groundwater } \\
(\mu \mathrm{g} / \mathrm{L})\end{array}$} & \multirow{2}{*}{$\begin{array}{c}\text { Surface Water } \\
(\mu \mathrm{g} / \mathrm{L})\end{array}$} & \multicolumn{3}{|c|}{ Analytical Method ${ }^{\mathrm{c}}$} \\
\hline & & & & Soil/Sediment & Groundwater & Surface Water \\
\hline Vanadium & 10 & 50 & 50 & $\begin{array}{l}\text { Method } 200.7 \\
\text { EPA CLP-M }\end{array}$ & $\begin{array}{l}\text { Method } 200.7 \\
\text { EPA CLP-M }\end{array}$ & $\begin{array}{l}\text { Method } 200.7 \\
\text { EPA CLP-M }\end{array}$ \\
\hline Zinc & 4 & 20 & 20 & $\begin{array}{l}\text { Method } 200.7 \\
\text { EPA CLP-M }\end{array}$ & $\begin{array}{l}\text { Method } 200.7 \\
\text { EPA CLP-M }\end{array}$ & $\begin{array}{l}\text { Method } 200.7 \\
\text { EPA CLP-M }\end{array}$ \\
\hline
\end{tabular}

a Recommended detection limits are equal to the EPA's contract-required detection limits (CRDLs), unless otherwise noted.

b When a recommended risk-based value is not achievable using standard analytical methods, an alternate value is presented in parentheses.

c EPA (1989). All referenced methods are modified in accordance with the CLP Statement of Work (SOW).

d Recommended alternate quantitation limit based on potential aquatic toxicity.

e Recommended alternate quantitation limit based on potential human toxicity.

f The quantitation limit for cyanide in soil and sediment was determined by the following assumptions: semiautomated spectrophotometric method, cyanide CRDL, 5-g sample, $250-\mathrm{mL}$ final volume of extraction solution, $70 \%$ solids, and $100 \%$ scrubbing efficiency.

g The detection limit for mercury in soil is the minimum value given for the range of the Method 245.5 CLP-M. 
TABLE C.5 Quantitation Limits and Analytical Methods for Principal Degradation Products of Selected Chemical Warfare Agents ${ }^{\mathrm{a}}$

\begin{tabular}{|c|c|c|c|c|c|}
\hline \multirow[b]{3}{*}{ CWA } & \multirow[b]{3}{*}{ Associated Degradation Product } & \multicolumn{2}{|c|}{ Quantitation Limits $^{\mathrm{b}}$} & \multirow{2}{*}{\multicolumn{2}{|c|}{ Analytical Methods ${ }^{c}$}} \\
\hline & & \multirow{2}{*}{$\begin{array}{c}\text { Soil/Sediment } \\
\text { ( } \mu \mathrm{g} / \mathrm{g} \text { or } \mathrm{mg} / \mathrm{kg})\end{array}$} & \multirow{2}{*}{$\begin{array}{l}\text { Water } \\
(\mu g / k g)\end{array}$} & & \\
\hline & & & & Soil/Sediment & Water \\
\hline Mustard (HD) & Thiodiglycol & 5,000 & 500 & HPLC-EC/UV & GC-FPD \\
\hline Mustard & 1,4-Dithiane & 2,500 & 5 & GC-FPD & GC-FPD \\
\hline Lewisite (L) & Chlorovinylarsine oxide & 500 & 100 & HPLC-EC/UV & HPLC-EV/UV \\
\hline Lewisite & 2-Chlorovinylarsonic acid & $-d$ & $1,000^{e}$ & - & IC-UV ${ }^{f}$ \\
\hline Lewisite & 2-Chlorovinylarsonous acid & $1,000^{\mathrm{e}}$ & $1,000^{\mathrm{e}}$ & HPLC-EC/UVg & HPLC-EC/UV' \\
\hline Sarin (GB) & Isopropylmethylphosphonic acid (IMPA) & $4,000^{\circ}$ & $200^{\mathrm{e}}$ & MPIC-EC/UV h & MPIC-EC/UV ${ }^{\mathrm{h}}$ \\
\hline Sarin & Methylphosphonic acid (MPA) & - & $200^{\mathrm{e}}$ & - & MPIC-EC/UV ${ }^{\mathrm{h}}$ \\
\hline Sarin & Dimethylmethylphosphonate (DMMP) ${ }^{i}$ & 500 & 100 & GC-FPD & GG-FPD \\
\hline Sarin & Diisopropylmethylphosphonate (DIMP) ${ }^{\mathbf{i}}$ & 500 & 100 & GC-FPD & GC-FPD \\
\hline vx & Methylphosphonic acid (MPA) & - & $200^{\mathrm{e}}$ & - & MPIC-EC/UV $V^{\mathrm{h}}$ \\
\hline vx & Ethylmethylphosphonic acid (EMPA) & $4,000^{\mathrm{e}}$ & $200^{\ominus}$ & MPIC-EC/UV h & MPIC-EC/UV ${ }^{h}$ \\
\hline Soman (GD) & Pinacolylmethylphosphonic acid & $4,000^{e}$ & $200^{\mathrm{e}}$ & MPIC-EC/UV ${ }^{h}$ & MPIC-EC/UV h \\
\hline Soman & Methylphosphonic acid (MPA) & - & $200^{\mathrm{e}}$ & - & MPIC-EC/UV ${ }^{h}$ \\
\hline Chloroacetophenone (CN) & Acetophenone & $660^{\mathrm{j}}$ & $210^{k}$ & GC/MS ${ }^{1}$ & GC/MS ${ }^{1}$ \\
\hline CS & Malononitrile & $100^{\mathrm{m}}$ & $100^{\mathrm{m}}$ & GC/MS ${ }^{n}$ & $\mathrm{GC} / \mathrm{MS}^{\mathrm{n}}$ \\
\hline Adamsite (DM) & 10,10'-oxybis(5,10-Dihydrophenarsine) & - & 1,000 & - & HPLC-EC/UV ${ }^{1}$ \\
\hline
\end{tabular}




\section{TABLE C.5 (Cont.)}

\begin{tabular}{|c|c|c|c|c|c|}
\hline \multirow[b]{3}{*}{ CWA } & \multirow[b]{3}{*}{ Associated Degradation Product } & \multicolumn{2}{|c|}{ Quantitation Limits ${ }^{\mathrm{b}}$} & & \\
\hline & & \multirow[b]{2}{*}{$\begin{array}{l}\text { Soil/Sediment } \\
(\mu \mathrm{g} / \mathrm{g} \text { or } \mathrm{mg} / \mathrm{kg})\end{array}$} & \multirow[b]{2}{*}{$\begin{array}{l}\text { Water } \\
(\mu g / k g)\end{array}$} & \multicolumn{2}{|c|}{ Analytical Methods ${ }^{c}$} \\
\hline & & & & Soil/Sediment & Water \\
\hline $\mathrm{BZ}$ & Benzilic acid & - & 1,000 & - & HPLC-EC/UV ${ }^{\mathrm{n}}$ \\
\hline $\begin{array}{l}\text { N,N'-Dichlorobis } \\
(2,4,6 \text {-trichlorophenyl)urea } \\
(\mathrm{CC} 2)^{0}\end{array}$ & bis $\left(2,4,6\right.$-Trichlorophenyl)urea (TCPU) ${ }^{\mathrm{p}}$ & - & - & GC-FPD ${ }^{q}$ & GC-FPD ${ }^{q}$ \\
\hline $\begin{array}{l}\text { N,N'-Dichlorobis } \\
(2,4,6 \text {-trichlorophenyl)urea } \\
(\mathrm{CC} 2)^{0}\end{array}$ & 2,4,6-Trichloroaniline $\mathrm{p}^{\mathrm{p}}$ & - & - & GC-FPD ${ }^{q}$ & GC-FPDq \\
\hline
\end{tabular}

a This table provides a comprehensive list of CWA degradation products for which quantitation limits and analytical methods are available.

b Unless otherwise noted, the referenced values are equivalent to USATHAMA target reporting limits and associated with standard USATHAMA analytical protocols. CWA degradation products detectable by available analytical methods are listed. Many more CWA degradation products, as well as stabilizers that may be present and detectable, will be listed in data reports, depending on analytical method and level of detection.

c HPLC-EC/UV = high-pressure liquid chromatography with a pulsed electrochemical detector and confirmation by ultraviolet detector; GC-FPD = gas chromatography with flame photometric detection; IC-UV = ion chromatography with an ultraviolet detector; MPIC-EC/UV = mobile phase ion chromatography with combination ultraviolet and pulsed electrochemical detector; GC/MS = gas chromatography/mass spectrometry.

d Quantitation limits or analytical methods have not yet been identified.

e This value represents a demonstrated method detection limit (MDL).

f Bossle et al. (1990).

g Bossle et al. (1989).

h Bossle et al. (1988).

i DIMP is a by-product formed during the manufacture of sarin. DMMP may be a production by-product or a degradation product of sarin.

j . Although the compound is listed under SW-846, Method 8270, a practical quantitation limit (PQL) has not been determined for soil. The referenced value is the PQL that is attainable for semivolatile compounds in soil by Method $8270 \mathrm{~A}$. 
'

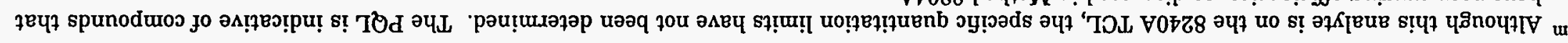

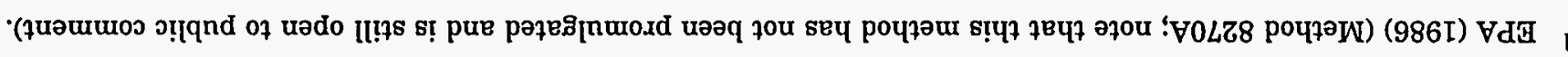

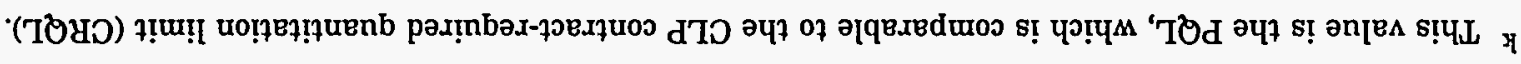


TABLE C.6 Quantitation Limits and Analytical Methods for Selected Explosives and Related Compounds

\begin{tabular}{|c|c|c|c|c|}
\hline \multirow[b]{3}{*}{ Chemical } & \multicolumn{2}{|c|}{ Quantitation Limits $^{\mathrm{a}}$} & \multirow{2}{*}{\multicolumn{2}{|c|}{ Analytical Method ${ }^{\mathrm{b}}$}} \\
\hline & \multirow{2}{*}{$\begin{array}{l}\text { Soil/Sediment } \\
\text { ( } \mathrm{gg} / \mathrm{g} \text { or } \mathrm{mg} / \mathrm{kg} \text { ) }\end{array}$} & \multirow{2}{*}{$\begin{array}{l}\text { Water } \\
\text { (ug/L) }\end{array}$} & & \\
\hline & & & Soil/Sediment & Groundwater \\
\hline Nitrobenzene & 0.26 & 0.5 & HPLC-UV & HPLC-UV \\
\hline 1,3-Dinitrobenzene & 0.25 & 0.5 & HPLC-UV & HPLC-UV \\
\hline 1,3,5-Trinitrobenzene & 0.25 & 1 & HPLC-UV & HPLC-UV \\
\hline 2,4,6-Trinitrotoluene (TNT) & 0.25 & 1 & HPLC-UV & HPLC-UV \\
\hline 2,4-Dinitrotoluene & 0.25 & 0.007 & HPLC-UV & HPLC-UV \\
\hline 2,6-Dinitrotoluene & 0.26 & 0.006 & HPLC-UV & HPLC-UV' \\
\hline Pentaerythritol tetranitrate (PETN) & 0.50 & 2 & HPLC-UV & HPLC-UV \\
\hline Nitroglycerin & 0.50 & 1.5 & HPLC-UV & HPLC-UV \\
\hline $\begin{array}{l}\text { Cyclotetramethylene tetranitramine } \\
(\mathrm{HMX})\end{array}$ & 2.2 & 1 & HPLC-UV & HPLC-UV \\
\hline $\begin{array}{l}\text { Cyclotrimethylene trinitramine } \\
\text { (RDX) }\end{array}$ & 1.0 & 1 & HPLC-UV & HPLC-UV \\
\hline $\begin{array}{l}n \text {-Methyl-n-2,4,6-tetranitroaniline } \\
\text { (TETRYL) }\end{array}$ & 0.65 & 5 & HPLC-UV & HPLC-UV \\
\hline Picric acid & 2.9 & $-\mathrm{d}$ & HPLC-UV & $\mathrm{d}$ \\
\hline Tetrazene & 1.3 & 7.3 & HPLC-UV & HPLC-UV \\
\hline 2,4,6-Trinitrobenzaldehyde & 1 & 1 & HPLC-UV & HPLC-UV \\
\hline
\end{tabular}

a Values listed are equivalent to USATHAMA target reporting limits.

b Referenced methods obtained from AEC (formerly USATHAMA) Technical Support Division, APG, Maryland. All methods are USATHAMA standardized methods for military-unique compounds.

c USATHAMA-certified low-level method.

d Analytical method has not yet been identified. 


\section{REFERENCES FOR APPENDIX C}

Bossle, P.C., et al., 1988, The Analysis of Alkyl Methylphosphonic Acids in Aqueous Matrices by Ion-Pair, Reverse-Phase Ion Chromatography, CRDEC-TR-88020, Chemical Research Development and Engineering Center, Aberdeen Proving Ground, Md.

Bossle, P.C., et al., 1989, Determination of Lewisite Contamination in Environmental Waters by High-Performance Liquid Chromatography, CRDEC-TR-042, Chemical Research Development and Engineering Center, Aberdeen Proving Ground, Md.

Bossle, P.C., et al., 1990, Determination of 2-Chlorovinylarsonic Acid in Environmental Waters by Ion Chromatography, CRDEC-TR-206, Chemical Research Development and Engineering Center, Aberdeen Proving Ground, Md.

EPA - see U.S. Environmental Protection Agency.

Kuronen, P., 1986, "Retention Indexes of Chemical Warfare Agents in Reversed-Phase HighPerformance Liquid Chromatography," Proceedings of the International Symposium on Protection against Chemical Warfare Agents (2nd), Stockholm, Sweden, June 15-19.

U.S. Environmental Protection Agency, 1986, Test Methods for Evaluating Solid Waste, Volume 1B: Physical/Chemical Methods, SW-846, Washington, D.C., Nov.

U.S. Environmental Protection Agency, 1988, Methods for the Determination of Organic Compounds in Drinking Water, EPA 600/4-88/039, Environmental Monitoring Systems Laboratory, Cincinnati, Ohio.

U.S. Environmental Protection Agency, 1989, U.S. EPA Contract Laboratory Program; Statement of Work for Inorganic Analysis, Multi-Media, Multi-Concentration, ILM010, SOW 788 (revised June 1989), Washington, D.C.

U.S. Environmental Protection Agency, 1991, Immunochemistry for Environmental Monitoring, Environmental Monitoring Systems Laboratory, Las Vegas, Nev. 
C-24 
$D-1$

\section{APPENDIX D:}

PROJECT SCHEDULES FOR THE ABERDEEN PROVING GROUND INSTALLATION RESTORATION PROGRAM 
D-2 


\section{APPENDIX D:}

\section{PROJECT SCHEDULES FOR THE ABERDEEN PROVING GROUND INSTALLATION RESTORATION PROGRAM}

\section{D.1 PROJECT SCHEDULES}

The following pages present scheduling for the Installation Restoration Program. The schedules are subject to periodic review and modification. 


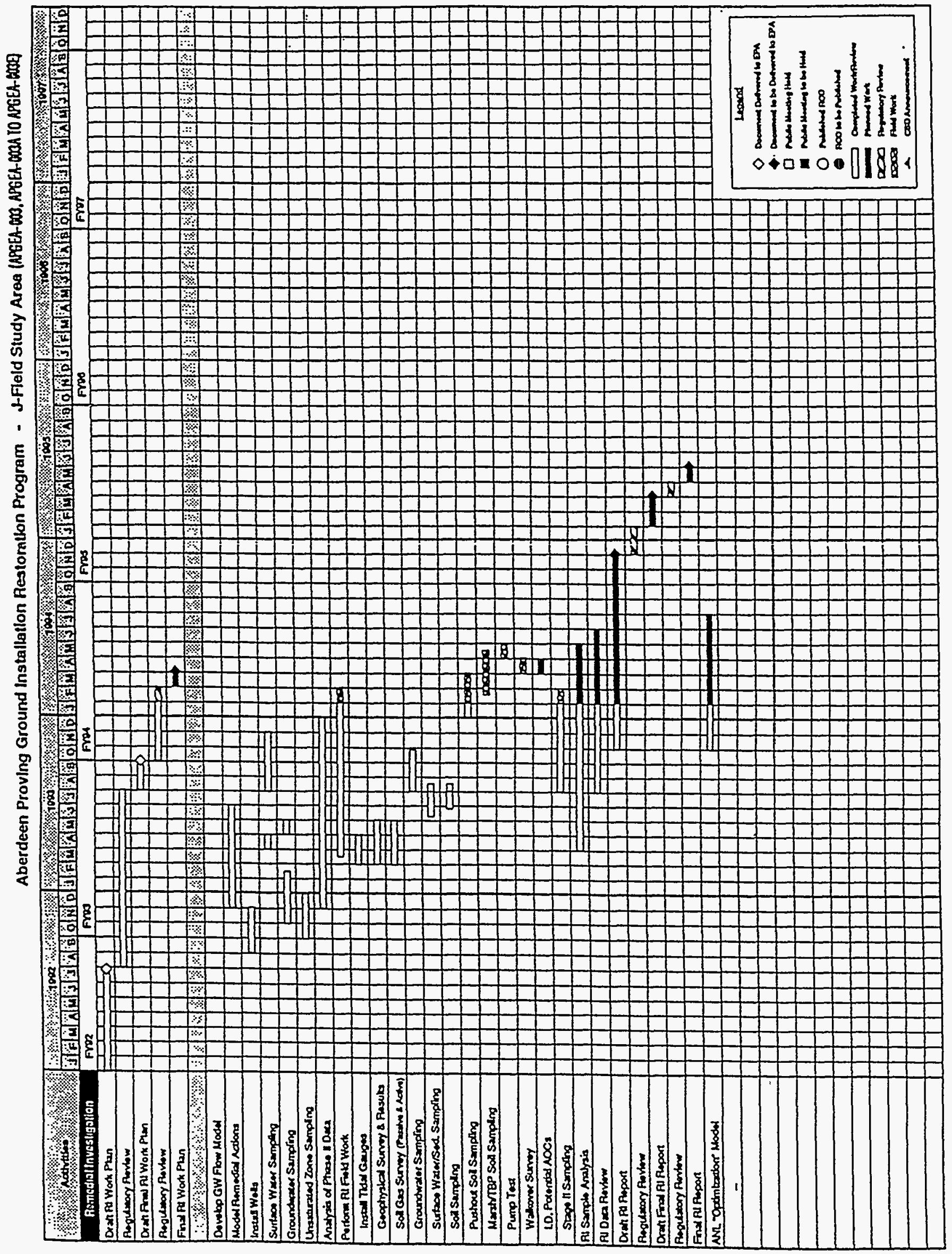




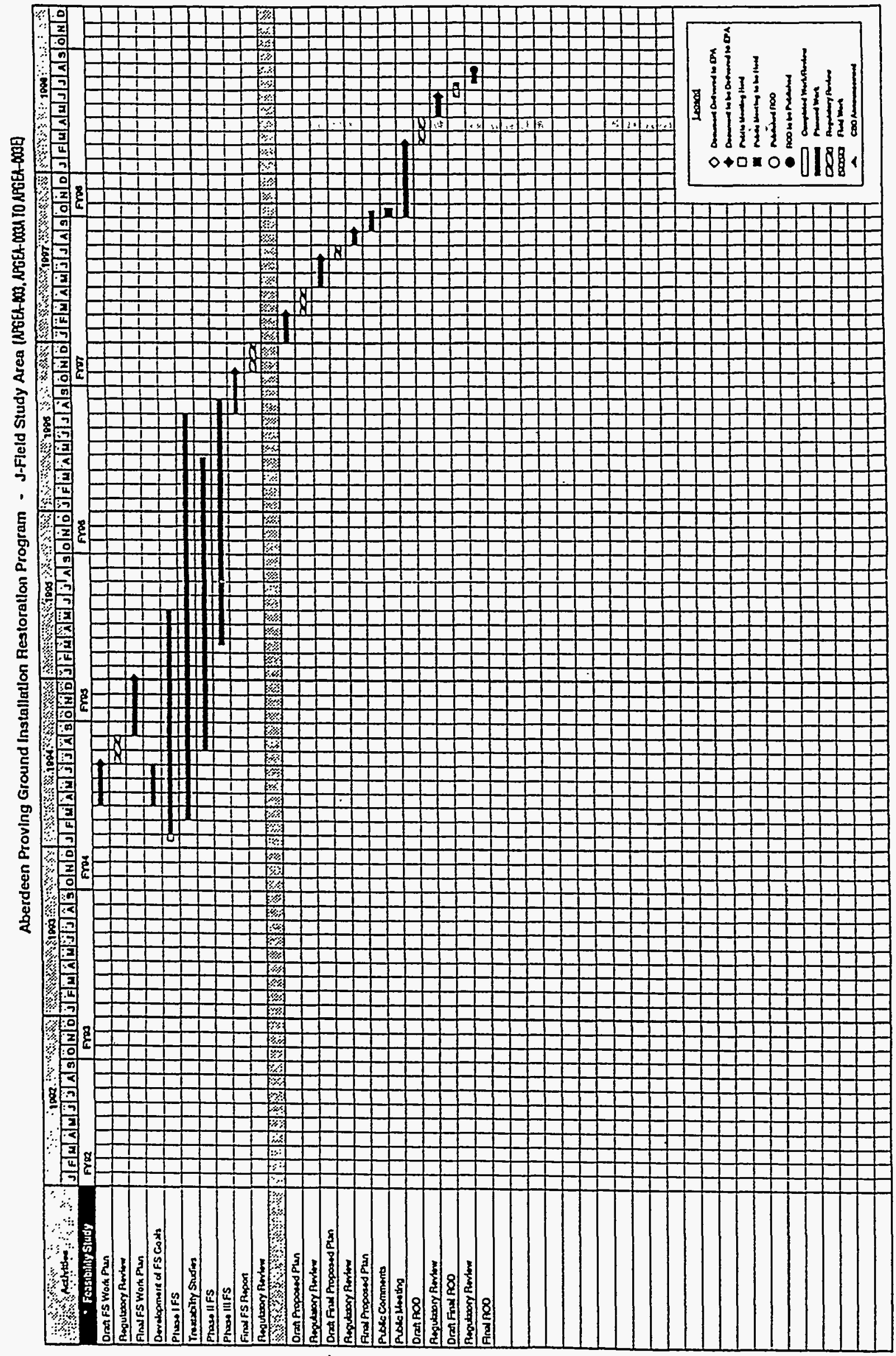




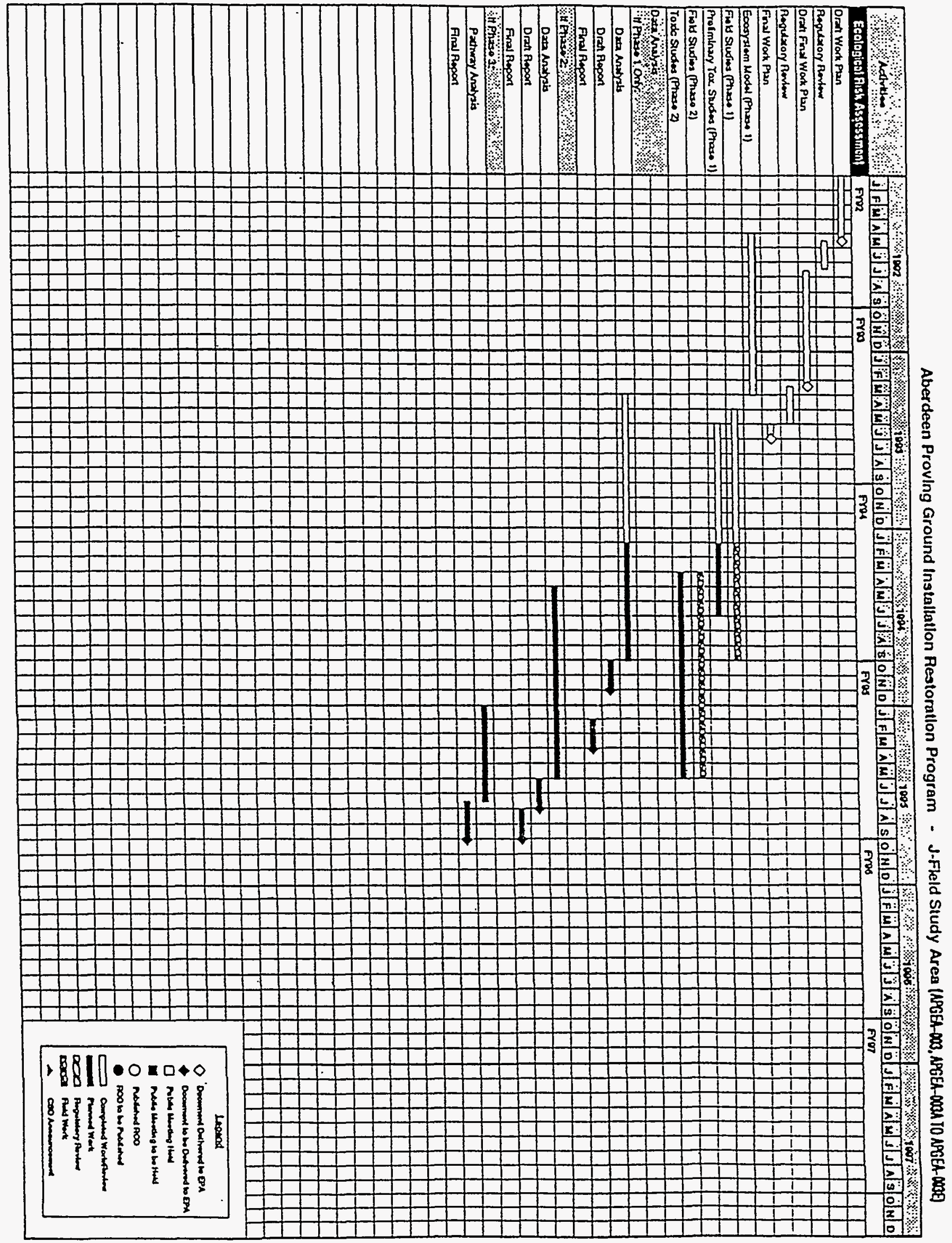




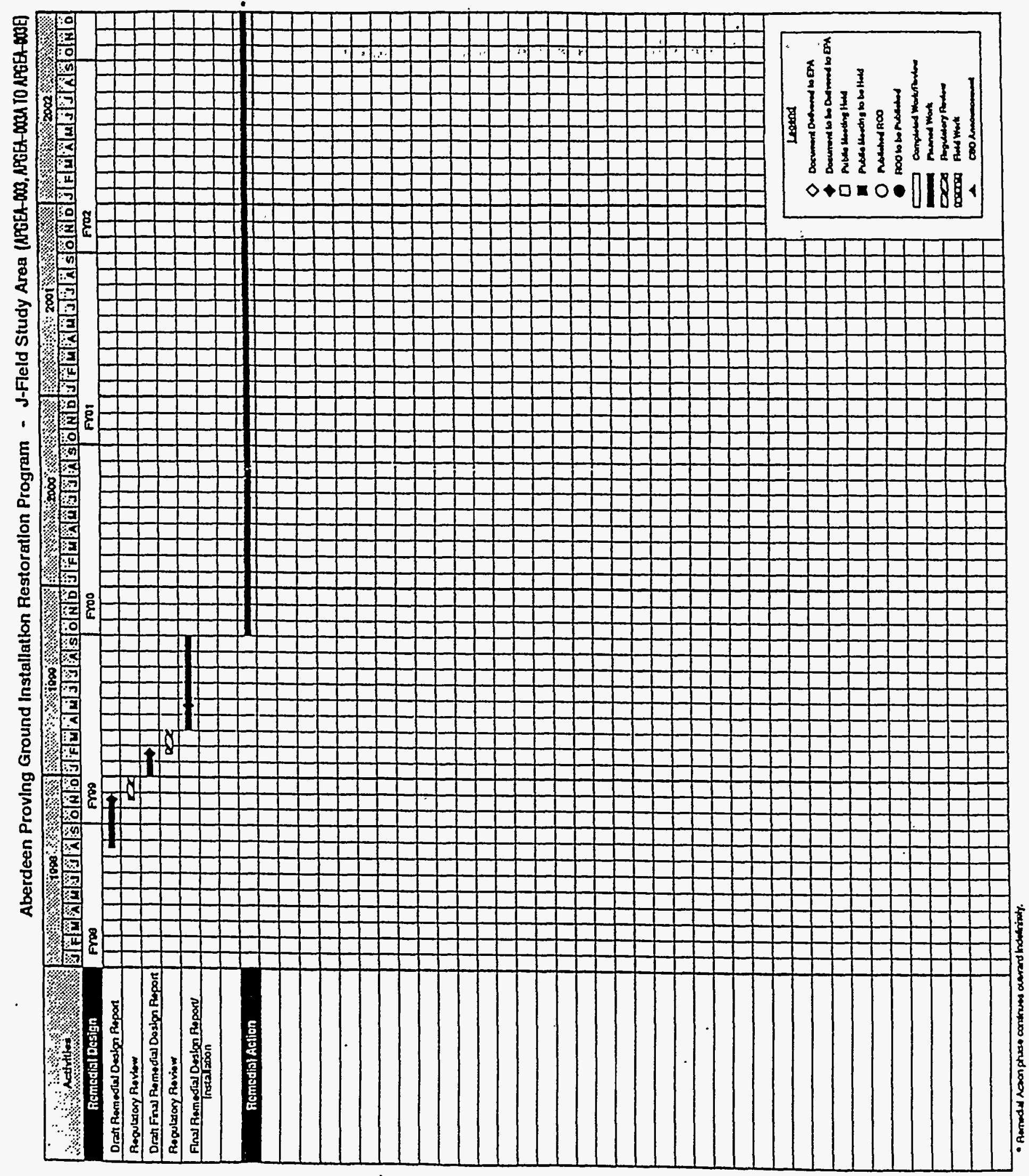




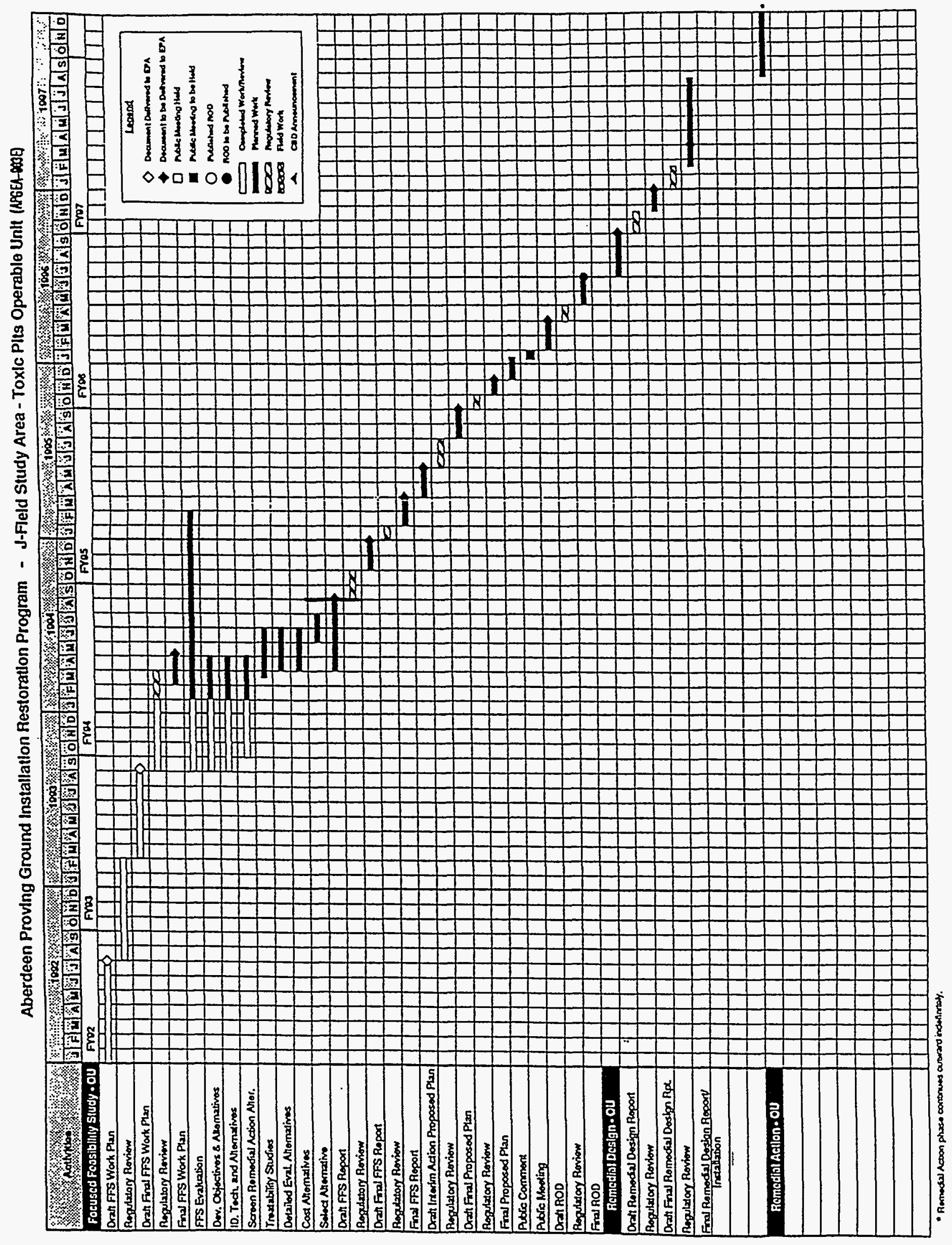




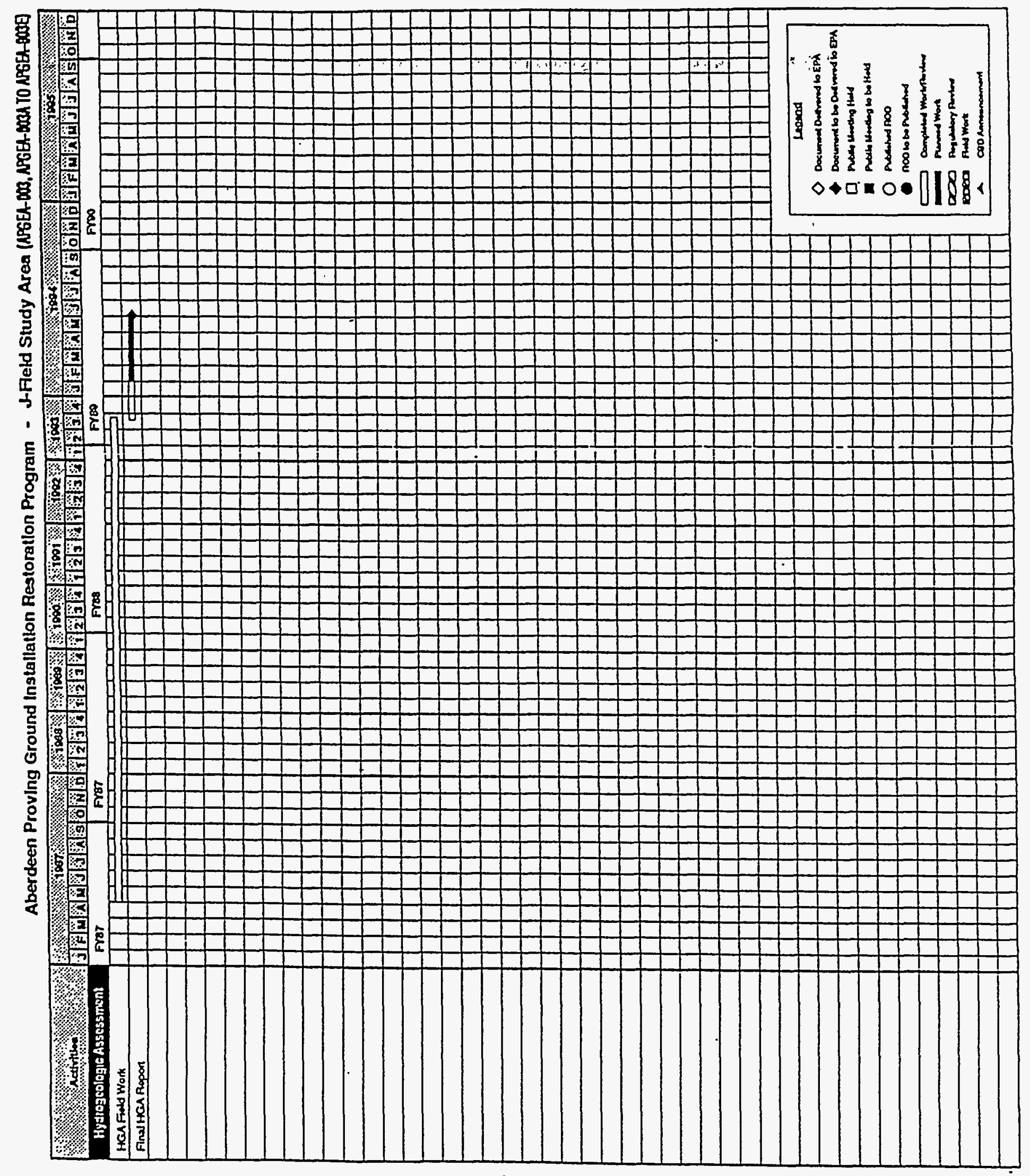


D-10

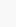

